\title{
THE CONSERVATION OF GROUND WATER
}

\author{
Harold E.Thomas
}





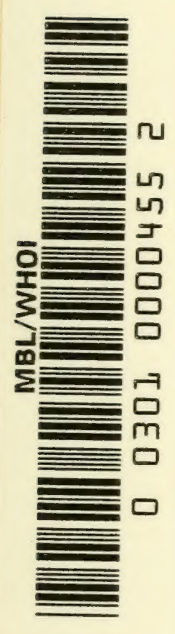





\section{THE CONSERVATION OF GROUND WATER}





\section{THE CONSERVATION OF 753 GROUND WATER}

A SURVEY OF

THE PRESENT GROUND-WATER SITUATION IN THE UNITED STATES

BY

HAROLD E. THOMAS

U.S. Geological Survey

Sponsored by

The Conservation Foundation

Frrst Edition

MGGRAW-HILL BOOK COMPANY, INC. NEW YORK TORONTO LONDON 1951 


\section{THE CONSERVATION OF GROUND WATER}

Copyright, 1951, by the McGraw-Hill Book Company, Inc. Printed in the United States of America. All rights reserved. This book, or parts thereof, may not be reproduced in any form without permission of the publishers. 


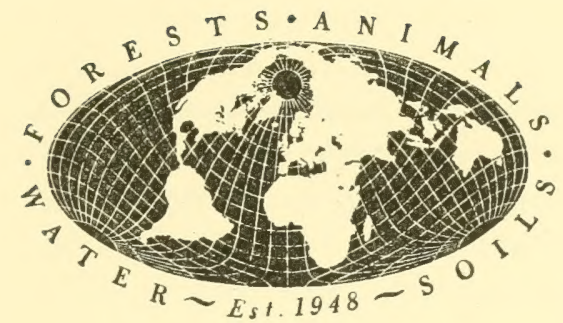

The Conservation Foundation was established in 1948 as an independent nonpolitical organization to investigate facts and to educate. It is dedicated to the conservation of the earth's life-supporting resources. 



\section{FOREWORD}

This book is the first of its kind to be published in the United States, for it not only surveys the natural conditions determining the occurrence of ground water but also describes the history and effects of ground-water use throughout the country. The Conservation Foundation has sponsored this survey to help define the present situation and to suggest courses of action.

Our nation is almost 200 years of age, yet it is only recently, due to recurrent warnings, that we are beginning to pay real attention to this essential resource, water. We are now forced to recognize how much we depend upon this daily necessityvital as the air itself. With the shock that comes from any new experience, about 40 million Americans, living in various regions and communities, are now realizing that they are face to face with problems of water supply. These problems are ones either of inadequate quantity, or unsatisfactory quality, or both.

The skeptic can observe with much justification that we human beings learn only from experience. The fact is that the people of our country, except those living in arid regions, have never had to think much about water supply. The combination of a fairly high average rainfall throughout most of our continent, together with superb natural arteries of large inland rivers and lakes, have deluded us into believing that water is one resource about which we need have no concern. Consequently a water problem is a brand new experience to many Americans.

Difficulties with water supply are bound to develop as time goes on. During our years of unawareness we have formed water-use habits which have become ingrained. Some of our present difficulties, for example, arise from lavish use or carc- 
less waste. As anybody knows, bad habits are hard to break, but the fact of the matter is that most Americans will have to readjust their attitude toward this paramount resource from now on.

Our population has doubled within the last 50 years. During this half-century our per capita consumption of water has also increased greatly. While some of this greater per capita use is due to domestic or municipal demands, a larger part is due to the tremendous drafts that are being placed on water supplies by the growth of agriculture and industry.

The time has come when we must abolish wasteful practices as well as introduce new water-saving methods, especially in critical areas. The over-all water supply is adequate for our nation, under all foreseeable future conditions, providing we inform ourselves fully regarding the facts and adopt programs through which the situation can be successfully dealt with.

Ground water is a natural resource upon which a large part of our population depends. It supplies many municipalities and is widely used in agriculture and industry. Recently, requirements for water, because of the growth of population and the spread of modern facilities, have strained existing facilities for tapping natural water sources. This strain is especially evident in the case of ground water. In many localities rates of withdrawal have exceeded those of natural replenishment. In some cases the result has been that salt waters have invaded fresh-water strata; in others, pumping costs have become very heavy.

These difficulties, widely publicized, have led some to conclude that our country is "drying up." Ground-water scientists assure us, however, that there is still a lot to spare, except in parts of the West where there has always been a natural deficiency of water. The problem is not necessarily one of reducing ground-water use. It is rather one of preventing overdevelopment of local areas by adjusting the use to the supply, and by tapping sources not now used. 
This book, reviewing over 70 areas where ground water has been investigated, classifies the main types of problems commonly encountered. This analysis will be mose useful to workers in the field for its summary of tested ways of interpreting the phenomena which each investigation presents. It should thus assist communities or regions in applying experience gained in other areas of the country.

We have still much to learn about ground water. This book examines many aspects of the Nation's ground-water situation requiring further research.

Since water and land, and the life they support, are intimately related to one another, the effects of use of the land and other resources on ground water are also treated. Greater investigation is required regarding these matters, too, and it is hoped that research will be accelerated as more people become aware of the consequences of ignorance and carclessness about resources. We cannot afford to damage the "economy of nature" that supports our life.

The Foundation wishes to express a great deal of gratitude to Dr. Harold E. Thomas, who was granted a leave of absence to conduct this study through the courtesy of the U.S. Geological Survey. He was aided by the Research Division of the Foundation. Our organization has benefited richly by its experience in working with Dr. Thomas on this publication. Warm appreciation is also expressed to Dr. Abel Wolman of The Johns Hopkins University for the concluding chaptes of this study. In a review of the varying circumstances of a number of representative areas, he discusses the major elements in policies of ground-water management.

While our experience as a Nation in developing groundwater resources has not been entirely happy, we have, in many cases, succeeded in adjusting our use of this resource to the natural conditions which determine its occurrence. We have also learned how to take advantage of natural reservoir space in certain localities by recharging water-bearing strata. These achievements provide encouragement that with suf- 
ficient investigation and forethought, and with reasonable regulation, this resource can always be available to the people of our country.

Such achievements also have great meaning in regard to our use of all renewable resources. Renewable is a really significant word because soils, plant life including forests, animals, and the waters that sustain them, all restore themselves naturally, again and again, if we give them proper care. As we learn more, therefore, of this living world upon which we depend, our obligation is the clearer to use it well.

\author{
FAirfield Osborn \\ PRESIDENT \\ THE CONSERVATION FOUNDATION
}




\section{PREFACE}

Since the end of World War II there has been a rather sharp divergence in published opinions regarding the national ground-water situation. The use of ground water in agriculture and industry increased greatly during the War. By 1945 this use had become about twice what it had been ten years before.

In 1948 The Conservation Foundation discussed this diversity of opinion with several ground-water authorities, who confirmed the need for analysis on a national scale of the detailed information collected from various parts of the country. A committee, composed of Dr. Abel Wolman of The Johns Hopkins University, Edward N. Munns of the U.S. Forest Service, Carl G. Paulsen and Dr. A. Nelson Sayre of the U.S. Geological Survey, and Homer Wells of the U.S. Soil Conservation Service, agreed to advise the Foundation in a project to summarize the national situation on the basis of the detailed information available. This volume is the report of that project, which was undertaken by the author during the year beginning July 1919. It is based upon published reports, unpublished data, and discussions with technical men in various Federal, state, and private agencies studying problems pertaining to ground water.

The author is extremely grateful for the guidance and great help given him during this project by each member of the Advisory Committee under the chairmanship of Dr. Wolman. Their personal interest in the success of the survey and their valuable criticism of the manuscript have contributed much to the clarity and comprehensiveness of this report.

The descriptions and conclusions of this report are based largely on the work of hydrologists and other scientists who carry on research on water-resource, and particularly ground- 
water, problems. These scientists are in the Departments of Agriculture, Army, Commerce, and Interior and several independent Federal agencies; in state water surveys or geological surveys or conservation departments or state engineers' staffs; in industrial concerns and consulting engineering, geological, or water-supply firms. Reference is made to some of the published clata in descriptions of specific problems or case histories. The author owes these men much more-ideas that he has gained in discussions and correspondence and in working with them, as well as suggestions and criticisms concerning parts of the manuscript; also verification of the data contained in the thumbnail sketches of 70 -odd problem areas in 35 states. These sketches, used to illustrate the types of ground-water problems occurring in the nation, describe areas which in the aggregate produce nearly two thirds of the ground water that the Nation takes from wells.

The author is especially indebted to Stephen W. Bergen, of the research staff of The Conservation Foundation, who worked with him throughout the period of the survey and assisted in the compilation and organization of the data and in the assembly of this volume.

Salt Lake City, Utah

Harold E. Thomas

March, 1951 


\section{CONTENTS}

Foreword by Fairfield Osborn vii

Preface

I. Introduction 1

The Problems 3

Our Increasing Requirements for Water 10

The Need to Know What We Are Doing 10

II. Hydrologic Principles and Basic Data 15

The Hydrologic Cycle $\quad 15$

Inventory of Our Water Resources 18

The gross water supply: precipitation 20

The surplus: stream flow 21

The return to the atmosphere: evapotranspiration 21

Delineation of Arid and Humid Regions 25

Nature's Great Reservoirs: Ground Water 27

Delineation of ground-water reservoirs of the United States $\quad 29$

Changes of storage in a ground-water reservoir 32

iII. Problems Resulting from Ground-water DevelopMENT AND UsE 35

Reservoir Problems 36

Reservoirs with natural replenishment inadequate for current uses

Perennial overdraft and emptying reservoirs, 37; The complication of introducing unusable water, 51; Corrective measures to reduce overdraft, 60 .

Reservoirs with natural replenishment adequate for present uses 77

Problems of maximum sustained development $\quad 92$

Pipeline Problems 98

Dispersed development remote from recharge areas 101

Concentrated draft from a part of a reservoir $\quad 109$

The danger of drawing unusable water into a reservoir

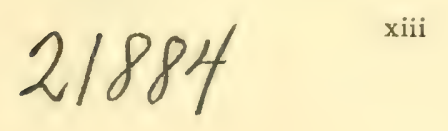


Watercourse Problems 136

Where the surface water is usable 138

Where the surface water is unsuitable for use $\quad 147$

Where the surface water is used downstream $\quad 150$

IV. Ground-water Problems Resulting from Land OcCUPANCY 161

Effects of Agricultural Use of Land 162

Effects upon infiltration and overland flow $\quad 164$

Effects upon storage in ground-water reservoirs $\quad 170$

Historic records, 170; Experimental research, 176.

Artificial replenishment of ground-water reservoirs 187

Effects of Urban Use of Land 191

Irrigation and Drainage 192

Rising water table in irrigated areas 193

Lowered water table in drained areas 194

Regulation of position of water table 196

Disposal of Wastes 200

Sewage $\quad 200$

Chemical wastes 203

River Control 205

Reservoirs 205

Regulated flow 206

Levees and flood walls 207

Navigation Channels 208

V. Our Increasing Requirements for WAter 213

Consumptive Use and Waste 215

Nonconsumptive Use and Disposal 217

Anticipation of Future Requirements 220

The Ground-water Quota in Meeting These Requirements

Vi. Current Deficiencies and Future Needs for Effective Ground-water Development 228

Hydrologic Data 228

Adequate inventory of water passing through the hydrologic cycle 231

Characteristics of ground-water reservoirs, 235; Inventory of water utilization, 237.

Manipulation of storage for maximum utilization of water

Legal Concepts 
Problems of water rights

Water rights inherent in land ownership, 245; Water rights based on priority of use, 246; Individual rights versus public rights in each phase of the hydrologic cycle, 250; Water rights based on preferential use, 252; Rights and responsibilities in physical and chemical properties of water, 254; Rights and responsibilities in cost of obtaining water, 255 .

Interrelationships of subdivisions of major drainage basins

Problems of regulating ground water

"Safe yield," 261; Reservoirs with negligible replenishment, 264; Effect of regulation upon present development, 264.

Water-conservation Practices

Public Enlightenment 269

Significance of "water-table" fluctuations 271

Possibilities of multiple use of water 272

Possibilities of manipulation of storage in groundwater reservoirs

Recognition of water resources as a vital factor in economics

VII. Better Ground-water Management by Abel Wolman

Some Representative Ground-water Problems 282

Major Elements in Ground-water Management 288

Appendix 1. Pumpage from Major Ground-water ReserVoirs in ORder of Magnitude

APPENDIX 2. INDEX OF LOCALITIES

Appendix 3. Selected Bibliography of Areal GroundWATER STUdies 



\section{Chapter I}

\section{INTRODUCTION}

Water is generally a renewable resource. In this respect it is like soil and plant and animal life. Rain and snow periodically replenish the natural supply of waters on the earth's surface and in the soil and in those reservoirs underground which supply wells and springs.

This natural supply of water, like that of other renewable (and nonrenewable) resources, is usually limited as to time and place. In recent years our use of this limited supply has grown enormously.

Because modern society has brought such heavy demands upon the Nation's water resources, the need to conserve them is now generally recognized. This recognition is a long step in the right direction. But clearly much more is required for the sound development, wise use, and protection of these resources. We require, for one thing, much more technical knowledge.

Because we are still deficient in this knowledge, the effective use and conservation of our water have been hampered. For we do not yet know enough in precise terms about the water resources available to us, or the use currently made of water throughout the Nation, or the effect of that use upon the supply. We know much about supply and use in many localities, but at present these patches of knowledge make up a crazy-quilt pattern; they cannot be brought together into a complete design, owing to the existence of large areas of the Nation for which only meager information is available.

Nor do we know nearly enough about the relationships which water bears to soils and to plant and animal life. IVe do not know enough about them either under natural condi- 
tions or as they are modified by our use of one or more of these resources. Modern agriculture, and modern industry in part, are sustained by intensive use of these related resources; this use affects our water supply in many ways. (Some of these effects are discussed in Chap. IV.) These relationships vary from one area to another, but for analysis, areas may be grouped by common characteristics.

Of all our water resources, least is known about those which are underground. This lack of knowledge has hampered their effective development as well as use and conservation. In some areas demands for ground water have increased even faster than for surface waters. Because of this tremendous growth in the use of ground water, many startling news reports have appeared in the press and on the radio about the groundwater situation in certain cities and other areas. In some parts of the country the water-level trend in most wells has been downward for several years. These areas are sufficiently numerous and widely scattered over the Nation so that they have given rise to statements that our ground-water resources are being depleted quite generally and may be exhausted within the lifetime of the present generation.

These apparent shortages of ground water are not limited to the desert areas where one might expect water resources to be precarious but have been reported in every state in the Union. In Louisiana, where rainfall is exceptionally plentiful, areas where water levels in wells are declining are more numerous than in Nevada, the most arid state. The more comprehensive statements have pointed out that the "shortage" is not universal and that in many other localities ground-water supplies are as abundant today as in the past. Some writers have called attention to our failure to make more use of ground water in these areas and have concluded that ground water is our most neglected natural resource.

There is a tremendous variety of natural conditions determining water resources of various localities, as well as a great variety of ways in which these natural conditions have been modified by man's activities. Much of the conflict in published 
statements concerning ground water and what we should do about it stems from this variety and from reference only to records concerning selected parts of the country. Thus it is true that in many areas water is pumped from wells faster than it is replaced by nature. Such overdevelopment affects the considerable part of our population dependent upon ground water for agricultural, industrial, and municipal uses, but the aggregate of these areas is less than 5 per cent of the country. In a much larger proportion of the country the water levels are not declining progressively, and in some areas groundwater storage has increased appreciably in the past several decades.

It is true, also, that throughout most of the Nation there has been little development of ground water. But those undeveloped regions include extensive areas where lakes and streams furnish all the water required and there is little demand for ground water. They also include extensive areas where adequate supplies of good water cannot be obtained from wells and large areas where very little is known about the ground-water possibilities. The areas where large, undeveloped supplies of ground water are known to be available occupy only a small fraction of the country's area.

\section{THE PROBLEMS}

The ground-water problems of one locality are rarely unique, for other localities have encountered similar problems and in many instances have found satisfactory solutions. These broad similarities in problems of various regions are brought out in the grouping and classification followed in subsequent chapters. Most of the serious problems of groundwater "shortage" are in areas where significant quantities of water are withdrawn from wells. Ground-water storage has also been changed by other activities of man, sometimes to his benefit, but more often to his disadvantage. Very commonly these changes, incidental to the settlement of the country, have been unintended and unforeseen.

The difficulties created by pumping from wells are of sev- 
eral types. Some problems pertain to entire ground-water reservoirs, ${ }^{1}$ where the rate of replenishment is inadequate to meet the continuing demand. In this report these are classed as reservoir problems. The second type, classed here as pipeline problems, arises because of the inability of water to move rapidly enough through earth materials to supply the demand of wells, even though the ground-water reservoir as a whole may have an adequate supply of water. The third type occurs along watercourses, where there is an intimate relation between the water in the stream and that pumped from wells. These are the watercourse problems.

The serious problems of ground-water shortage are in areas where water is pumped out faster than the entire groundwater reservoir is replenished. Under these conditions the reservoir is being emptied of water that may have taken decades or centuries to accumulate, and there is no possibility of a continuous perennial supply unless present conditions are changed. Even more serious is the condition where salty or otherwise unusable water flows into a ground-water reservoir as the good water is pumped out, for these reservoirs may be ruined before they are emptied. Nearly all these excessively pumped reservoirs are in the arid regions, where precipitation

1 As the term is used in this report, a ground-water reservoir consists of saturated rock materials sufficiently permeable that water can move through them by gravity and can be withdrawn from them by wells. Characteristically, water enters ground-water reservoirs by downward percolation from the land surface in certain areas known as recharge areas, and moves laterally underground toward areas of natural discharge, where it reappears at the surface. The terms "aquifer" and "water-bearing formation" are commonly used inter. changeably with "ground-water reservoir." The characteristics of ground-water reservoirs are discussed further on pages 27 and 32.

The term "ground-water reservoir" is used in a more restricted sense by many writers to designate, for instance, the water-bearing formations underlying a city or other limited area, or the aquifers in which water is confined under artesian pressure. Such limitations are especially common in detailed studies of areas too small to permit analysis of the entire underground phase of the hydrologic cycle (see page 33). On the other hand, some writers refer to the "ground-water reservoir" of the United States as if all parts of the land area were underlain by permeable rock materials. Actually, facilities for storage of water underground are exceedingly variable from one geographic area to another. 
is generally inadequate for the needs of man. Some have an area of a hundred square miles or less; others may embrace several counties or extend across state or international boundaries (see Plate II). Generally, the ground-water users are aware that they are using more than the perennial supply and that the supply will be exhausted unless action is taken. Corrective measures already applied in certain areas include prevention of waste, prorata reduction of pumping from all wells, prohibition of further development, reclaiming of used water, artificial ground-water replenishment by surplus stream water, and importation of water from other areas.

Not all the ground-water reservoirs in the arid regions are overdeveloped. Many have potentialities for additional development, though not because they are more favored in replenishment than the fully developed or overdeveloped reservoirs. Rather they are less favored by people, for lack of fertile land or mineral resources, agreeable climate, or for other reasons. The potentialities of most of these undeveloped reservoirs are not great, due to the low rates of precipitation and groundwater replenishment that prevail throughout the arid lands. In fact, in some areas practically uninhabited at the end of World War II, the ground-water reservoirs now appear to be overdeveloped, after only a few years of intensive well drilling and pumping.

A few ground-ivater reservoirs receive very little natural replenishment. Some are in deserts where replenishment occurs only after exceptional rainstorms that may be several years apart; others are almost completely sealed off by clay or other material that impedes entry of water from precipitation or from other sources. The water in these reservoirs can hardly be classed as a renewable resource. Where the quantity stored in them is large, there is a real problem involved in development: should the water be extracted for maximum benefit of the present generation, as minerals and other nonrenewable resources are mined, or should the pumping be limited to the negligible quantity that can be supplied perennially?

The pipeline problems are due chiefly to the slow rate of 
movement of water through earth materials. If water is unable to move toward a well rapidly enough to replace the water pumped out, the pump inevitably takes water from progressively greater depth in the immediate vicinity of the well, the pumping lift and cost of pumping increase, and the well eventually may be pumped dry. This certainly indicates a shortage of water at the well but not necessarily an insufficiency of water in the ground-water reservoir. Indeed, water levels have declined markedly in small portions of some reservoirs whose recharge areas are annually filled to overflowing; but the recharging water moves too slowly to the areas where wells are pumped. In ground-water reservoirs being emptied because the total replenishment is less than the draft, pumping from closely spaced wells accelerates the declining trend of water levels in some areas.

Pumping from closely spaced wells has caused significant declines of water level in parts of nearly every state (see Plate III), chiefly in municipal or industrial areas that use large quantities of ground water. Water levels have reached approximate equilibrium in some of those areas, indicating that the pumped water is now being replaced by water transmitted through the aquifer. In other areas the water levels are still declining each year. Concentrated draft has induced inflow of ocean water or other unusable water to some wells. In several places along the Atlantic, Gulf, and Pacific Coasts, wells have been abandoned because of this contamination.

The greatest recorded declines of water levels have been in areas of concentrated draft from artesian aquifers. Wells in many localities reach water that once was under sufficient pressure to flow at the surface, or at least to rise above the top of the aquifer that holds the rvater. The artesian pressure is created by a capping layer of impermeable naterial over the aquifer, and the water taken from artesian wells must be replenished by movement from recharge areas that may be many miles distant. If the pumpage exceeds the underground flow from the recharge areas, a decline of water levels is inevitable.

In the areas of local overdraft perennial supply can be as- 
sured only when the draft from the wells is balanced by inflow to those wells. The remedial measures undertaken to date have involved reducing the draft or increasing the inflow to the developed area, or both. Many areas of overdraft are small in extent, and many also are in humid regions, where additional water supplies are available at no great distance.

It has been easy to reduce the draft by tapping other sources of water, and many cities and industries have developed stream, lake, or reservoir sources as they have outgrown the facilities of ground-water reservoirs in the vicinity. Others have tapped other ground-water reservoirs or even the same reservoir at some distance from the area of overdraft. Continued pumping in disregard of declining water levels has tended to reduce the yield from individual wells, though also increasing the rate of inflow to the area of overdraft by steepening the hydraulic gradient from the recharge area. In such cases, however, the water is obtained at progressively greater cost.

In order to obtain increased supplies without excessive pumping lifts and particularly without contamination by ocean water, the natural recharge has been increased in several places by the use of spreading areas, ponds, and recharge wells.

The watercourse problems result from pumping wells along rivers, where the ground water is so closely related to the water in the stream that pumping from wells depletes the stream flow. Diversions from the stream for various purposes may increase the amount of ground water at one place and reduce it at another. The intimate relation between surface and ground water is also shown at some river cities where protection from floods requires not only protection from a rise in the river but also protection from the simultaneous rise of ground-water levels under the city.

Many problems have arisen as wells along watercourses have been pumped: some because the pumped water is not readily replaced from the stream; others because it is readily replaced but the stream water is either needed downstream or is unsuitable for use. Some wells close to streams produce 
water free of bacteria even though the stream is highly polluted, but there has not been enough research to show quantitatively the effectiveness of aquifers in reducing bacterial pollution. It is likely that the utilization of ground water along watercourses will increase because of this reduced degree of pollution and because of more uniform temperature and quality of the ground water. Studies at a few places along rivers indicate that large quantities of ground water are available, with the river as the ultimate major replenishing source.

Many activities unrelated to pumping of ground water have modified the storage of water below the land surface. Drainage projects and irrigation projects have proved that it is possible to manipulate the storage in ground-water reservoirs. Unfortunately, ground-water storage has been increased by irrigation in some places until good agricultural lands have been waterlogged and abandoned; and it has been decreased in other localities by drainage to the detriment of agricultural use of the land or municipal use of the water. Man has changed the quantity of water stored underground by his structures for storage of surface water or for protection against floods, by improving channels for navigation, and by building cities and providing them with storm sewers. He has damaged some water supplies by discharging contaminated water into the ground or into streams from which it enters ground-water reservoirs; and also by puncturing protective layers, thus permitting entry of sea water or other mineralized water into aquifers.

For the country as a whole, the greatest change wrought by man has been the change from the original forest and grassland to cultivated or barren areas. This change has had a profound effect upon the soil cover, as shown in areas of severe gullying and wholesale remoral of the soil and more extensive areas where the soil has been eroded less markedly. That lost soil now forms part of the sediment in many stream channels, lakes and reservoirs, and ocean bottoms. Although the effects of man's activitics may be measured in millions of tons of displaced soil, these effects are insignificant in comparison with 
the work of natural forces, the forces which have in geologic time reduced mountain ranges to low-lying plains and accumulated sediments to thicknesses of thousands of feet. Generally man can claim credit only for hastening or increasing the natural processes of aggradation and degradation.

In the absence of actual records of ground-water levels in wells since the beginning of settlement, there is a broad field for argument as to the effects of these changes in vegetative cover upon ground-water storage. It is certain that where the earth materials were saturated to within a few feet of the surface, the cutting of deep gullies has lowered the water table as effectively as ditches have done for numerous drainage projects. Beyond that, the historic records are inconclusive. The declining trends of water levels in areas of pumping are poor evidence of the effect of land use because they can so obviously be due to the pumping. On the other hand, records of water levels in wells unaffected by pumping do not extend back far enough into the past to show whether or not there has been depletion of ground-water storage in the past two centuries, or to what extent long-term climatic trends might be responsible.

Scientific research has documented the relation of the land surface to the replenishment of subsurface water supplies and also the great variety of factors involved in that relation in various localities. Through this research effective methods have been developed for reducing or eliminating overland flow of water from precipitation and for increasing the infiltration of water into the ground. These methods have been applied in many areas with resulting increase of storage of water in the soil and in the entire zone above the shallowest impermeable material; the yields of wells and springs have been increased also in numerous localities. In addition, overland flow of water has been reduced, with consequent reduction of soil erosion, of turbidity in streams, and of sedimentation in stream channels.

The increased infiltration and reduced overland flow is not achieved without cost, however. Any vegetative cover uses water, and in some instances that use may be a high proportion 
of the total precipitation. It is because of this water cost that treatment of some watersheds can reduce overland flow, increase infiltration and soil moisture, and yet not cause any perceptible increase in storage in an underlying ground-water reservoir.

\section{OUR INCREASING REQUIREMENTS FOR WATER}

Available information indicates that the total water used for irrigation, industrial, and public supplies throughout the $\mathrm{Na}$ tion may be as great as 200 billion gallons a day, of which probably less than 40 per cent is actually consumed and returned to the atmosphere. Thus the national use is nearly 200 times that of New York City's 8 million inhabitants. Probably less than 15 per cent of this total is derived from ground-water sources. It has been predicted that the current usage may be doubled within a few decades, judging by the trend in recent years and the indications of large additional demands for new purposes. It is likely that ground water will be called upon to continue to furnish the same, if not an increased proportion of the total demand, because of recognized advantages in uniformity of quality and quantity.

What will be the result of any effort to increase our groundwater development so tremendously? Certainly, if we continue the pattern of development of the past few decades, the likelihood is that current ground-rater shortages in many areas will be intensified and many new "critical" areas will be created. This would be an appalling predicament and a sad commentary on the Nation's astuteness, in view of the known possibilities for far more effective utilization of the available supplies.

\section{THE NEED TO KNOW WHAT WE ARE DOING}

The imperative need in ground-water development, past and future, is to know what we are doing. That knowledge comes from probing into the methods by which nature puts water into the ground and takes it out again, as well as the changes that man makes or can make by his activities. 
Past development of ground-water reservoirs has generally been in ignorance of their potentialities and especially their limitations. Realization of the limits of surface supplies came early, particularly in the arid states, where deficient precipitation sets a low ceiling on all water supplies. The limitations in ground-water supplies in those regions became apparent much later and are just beginning to be apparent in humid regions.

Most of the scientific analysis of ground-water problems to date has been restricted to the ground-water phase of the hydrologic cycle, and recommendations for optimum utilization have been based largely on the rate of natural replenishment. In many ground-water reservoirs this quantity is large enough to permit utilization of far more water than is currently developed. But in many places, if we knew enough, it might be possible to utilize ground-water reservoirs like surface reservoirs, storing water in them by artificial recharge, and manipulating that storage to best advantage, rather than merely drawing out what nature puts in. Successful manipulation of ground-water storage will require full knowledge of groundwater reservoirs as components of the hydrologic cycle, and, therefore, a comprehensive analysis of the meteorology of the area, as well as the hydrology of soil moisture, ground water, and surface water. Studies in many areas have already shown the intimate relation of ground water to surface water, and of both to infiltration and soil moisture.

The recharge areas are of critical importance in the artificial replenishment of ground-ivater reservoirs. Effective treatment of them may well require many of the basic practices which have been successful in soil and soil-water conservation. Wherever replenishment of ground water is the principal objective, rather than an incidental benefit of the program, there should be assurance that the ground-water supplies are actually being increased. Many ground-water reservoirs have been successfully recharged artificially by various methods. For the majority of reservoirs considerable scientific investigation is needed before a workable program of artificial recharge can 
be formulated. In the country as a whole, there are doubtless some areas where soil conservation and water conservation are mutually beneficial, some where either may be undertaken without affecting the other resource, and some where conservation of one will be detrimental to the other.

Few ground-water reservoirs are yet utilized to store flood flows for later use, and they are generally not even considered in river-basin flood-control and storage programs. Yet many have a capacity far greater than the largest artificial reservoirs. They can provide holdover storage with minimum loss of water by evaporation and with minimum loss of productive land. Some certainly deserve a far larger place in plans for complete water development but cannot attain that place until hydrologic knowledge is sufficient to show the way to successful manipulation of ground-water storage.

The lack of adequate hydrologic data is recognized by technicians in all fields related to development and utilization of water resources. Many have stressed the need for far more basic data to ensure that these developments be sound and economical. There is need for more research in the basic principles of hydrology and in techniques and equipment for measuring the quantities of water moving in each plase of the hydrologic cycle. Comprehensive planning for development of all water resources requires a well-coordinated analysis of a great variety of data by scientists in many specialized fields. The large number of Federal, state, and other agencies responsible for and authorized to conduct research in those several specialized fields have endeavored to achieve this coordination on a voluntary basis but with limited success.

The need for more ground-water data is especially acute in river basins where comprehensive development of water resources is planned or actually under way. In most river basins the ground-water data are so meager that proper evaluation cannot be made of the potentialities of ground-water reservoirs, and those reservoirs are therefore ignored in the development plans. Indeed, the ground-water conditions are known with reasonable reliability in only about 5 per cent of the Na- 
tion's area. In three-fourths of the country there is practically no detailed information concerning the ground-water reservoirs.

Intelligent development of water resources is dependent upon a framework of law that will permit achieving the wisest use of the water and will prevent activities that would defeat the purpose of the development. To that end, the legal rights and responsibilities of each water user should be clearly defined. Unfortunately, much of the existing water law is unsound, chiefly because it has been developed on the basis of meager hydrologic facts and in some cases incorrect assumptions. As a result, some statutes and court decisions are so written as to preclude effective development and maximum utilization of water. A body of workable water law is needed for effective control of development and to protect water rights. But first there must be adequate reliable information upon which to base determinations as to questions of fact and questions of law. Many of the defects of existing water law can be overcome as our knowledge of the water resources expands, although some lag is inevitable. In the present status of development, which is considered to be still far from the full potential in most states, restrictions on water use should be the minimum consistent with effective control. Maximum reliance should be placed upon voluntary cooperation of water users.

In the conservation of all renewable resources, water plays a part not only in its own right but in sustaining the other resources. Some problems and conflicts have already arisen, where the planned use and wise management of these other resources involves some cost in water, or vice versa. Real conservation requires a balanced program in which the relative importance of all of the individual resources in each locality is recognized. Intelligent action requires detailed information and analysis by small units, and broad regional generalizations may be very unsound without this specific attention to details. For the purpose of this broad-brush national survey, however, some generalization may be permitted.

Water is the critical resource in most of the semiarid or more 
arid parts of the country. It will set the limit on the use that man can make of the other resources, and thus ultimately on the density of population and the standards of living that can be sustained in those regions. In the regions of abundant rainfall, however, water should not be the first of the natural resources to falter. Nature generally provides a surplus of water in those regions that flows to the sea, and this surplus can be put to many uses. Even here local shortages of water may develop, because of failure to pattern the development and use in accordance with the availability of the resources. Our present knowledge of water resources, though far from complete, is enough to justify the assertion that considerably more development can be made of the water supplies in humid regions without exhausting the supplies or ruining them for others. 
Chapter II

\section{HYDROLOGIG PRINGIPLES AND BASIC DATA}

\section{The Hydrologic Cycle}

Water suitable for irrigation or for industrial or public use is obtained from many sources, including streams, reservoirs, lakes, wells, springs, drain tunnels, infiltration galleries, cisterns. These sources will yield a perennial supply to the extent that they are replenished by precipitation seasonally, annually, or at less frequent intervals. However, only a fraction of the water from precipitation may be expected to replenish these surface and ground-water resources. The rest returns to the atmosphere by evaporation from soils or ponds, etc., and by transpiration through the leaves of plants; that is, by processes collectively called "evapotranspiration." The net water supplies available for our continuing use in desert areas are a very small percentage of the gross supply that falls as precipitation. In cool, humid areas the available water supplies may be more than half the gross supply.

Precipitation and evapotranspiration are processes in the natural circulation of water which is going on at all times. The term "hydrologic cycle" has been applied to the march of events marking the progress of a particle of water from the atmosphere to the land masses and occans and its return to the atmosphere. The two basic forces that keep the cycle going are solar energy and the gravitational pull of the earth. Gravity is the controlling force not only in the precipitation but in the downward movement of water thereafter in streams or below the land surface. Underground, molecular attraction becomes an important force that resists the movement of water by 
gravity. Where the openings or pores in rocks are sufficiently minute, the force of molecular attraction is powerful enough to prevent any movement of water through them.

The effectiveness of the solar energy in pulling water back to the atmosphere varies from time to time and from place to place, but this force is operating at all times upon all water within reach. Water is evaporated from oceans, lakes, reservoirs, streams, canals, swamps, regetation, and moist earth; it may evaporate as soon as it hits the ground-or even before -in hot deserts, and it may return to the atmosphere from snowbanks or ice fields at temperatures far below freezing; it is transpired by all vegetation, and thus the "reach" of this solar force extends below the land surface as far as plants can send their roots for water, or in the absence of vegetation, as far down as air can circulate.

The science of hydrology embraces all phases of the hydrologic cycle. So complex is each of these phases that hydrologists must also be specialists in one or more of the closely related sciences of meteorology, soil science, geology, chemistry, physics, biology, forestry, and agronomy. Partly because of the complexities of the hydrologic cycle and partly because of the high degree of specialization of technical research, there are only a few small arcas where we yet have a reasonably complete and quantitative description of the operations of the hydrologic cycle. We know how variable the paths of a particle of water in the hydrologic cycle can be in various parts of the country. Of the water that reaches the land surface by precipitation, some may evaporate where it falls; some may infiltrate into the ground; some may run off overland to evaporate or infiltrate elsewhere or to enter streams. Of the water that infiltrates into the ground, some may be evaporated; some may be absorbed by plant roots and then transpired; some may percolate downward to ground-water reservoirs or into voids and crevices in relatively impcrmeable material. Of the water that enters ground-water reservoirs, some may move laterally until it is close enough to the surface to be subject to evaporation or transpiration; some may reach the land sur- 
face and form springs, seeps, or lakes; some may flow directly into streams or into the oceans. Of the water in streams, some may accumulate in lakes and surface reservoirs; some may be lost by evaporation or transpiration of riparian vegetation; some may seep downward into ground-water reservoirs, and some may continue on to the oceans. The hydrologic cycle is completed by evaporation from the oceans and circulation of water vapor in the atmosphere.

Lest it appear that because of these apparent multiple choices, the path followed by a particle of water is entirely fortuitous, it should be stressed that there are definite priorities for that movement. Except for the water that evaporates at the surface, the soil or mantle-rock has top priority upon the water that falls as precipitation. Overland runoff does not occur unless or until precipitation exceeds the capacity of that surface layer to absorb the water. The soil holds water against the force of gravity until its field capacity is reached, that is, its capacity for holding water by molecular attraction, and only then does water start to percolate downward under the force of gravity. In the intervals between storm periods soil moisture may be depleted by evaporation and transpiration, and this depletion must be made up during subsequent storms before there can be additional downward percolation.

Ground-water reservoirs, including those perched upon impermeable rock layers, receive the water that percolates downward from the soil zone. These reservoirs, or aquifers, are composed of materials sufficiently permeable that water can move through them by gravity. Water accumulates until the reservoir is filled sufficiently to cause underground flow, which may ultimately be discharged into lakes or stream channels or oceans, or at the land surface by springs or seeps. Where ground water is at shallow depth, it may be discharged by evaporation or transpiration.

Streams are the spillways of the hydrologic cycle and carry off the surplus water that is not stored in lakes or underground or returned to the atmosphere by evapotranspiration. They have the lowest priority on water that falls as precipitation, for 
water enters a stream only if it falls directly in the channel or if it cannot get into the ground by infiltration or if it is discharged into the stream from ground-water reservoirs. Even after water has reached the stream, it may be lost by evapotranspiration or disappear by seepage into underlying groundwater reservoirs.

The great differences in ground-water resources and in stream-flow characteristics in various parts of the country are traced not only to differences in rates of rainfall and other climatic factors but to differences in the materials in and below the soil zone, through which the water may pass. In some places the soil is like a blanket over the earth, absorbing the rainfall even of intense storms until it can hold no more, so that some starts moving downward into underlying rock materials; in other places bare rock or other impermeable material or frozen or compacted ground cannot absorb the water even of moderate storms or of gradual snow melting, and the surplus may cause a stream to flood.

The underlying rock materials may be very permeable and form part of a ground-water reservoir capable of transmitting large quantities of water for considerable distances, finally discharging the water at a fairly constant rate into streams. In other places, downward percolation may be stopped within a few feet or even a few inches of the surface by an impermeable layer, and the water collected above that layer may quickly reappear in streams only a short distance away, perhaps soon enough to contribute to floods in those streams.

\section{INVENTORy OF OUR WATER Resources}

Systematic inventories are maintained of the reserves of most of the nation's minerals of economic value, such as gold, petroleum, coal, uranium, iron. We know from our continuing discoveries of new oil fields or mineral deposits that this inventory is by no means complete, and we hope for posterity's sake that the reserves still unknown may be large. Nevertheless for each known ore body there are established methods 
for determining the extent and value of the minerals therein, from which an estimate of the total reserves in the deposit may be made. Thereafter the computations of depletion by mining and of rescrves still underground are bookkeeping operations, continued until the mineral deposit is exhausted.

Water is different. Except in a very few places it is a transient resource which cannot be conserved for the future merely by not using it. On the other hand, utilization of water does not necessarily mean that the Nation's reserves are being depleted, for the great majority of uses are made possible by diversion of water which would otherwise continue through the hydrologic cycle to be discharged into the atmosphere or into the ocean. Because our water resources are both renewable and mobile, the available reserves at any one place are continually changing, and an inventory runs into problems similar to those met in determining the density and flow of traffic along a system of highways.

A complete inventory of water resources requires continuing maintenance of representative check points at the land surface to determine the gross water supply from precipitation and the return to the atmosphere by evaporation and transpiration; in the soil zone to determine changes in soil moisture and amount of downward percolation; in the groundwater reservoirs to determine changes of storage, lateral movement, and ultimate discharge; in streams to determine outflow from drainage basins and the gain or loss within these basins; in the developmental works of man to determine consumptive use and waste as well as nonconsumptive use and disposal; and throughout the cycle to determine changes of chemical, physical, or biological quality of the water that might affect subsequent utilization.

For the country as a whole no phase of the hydrologic cycle is completely inventoried. The data concerning precipitation and stream flow are sufficiently comprehensive to provide reasonable estimates of the gross water supply and of the surplus carried by streams flowing from the Nation's borders, by longterm averages as well as annually, seasonally, or for shorter 
periods. The total amount of water returned to the atmosphere by evapotranspiration is derived by subtraction, but we do not know enough about ground water or soil water, or about infiltration, evaporation, or transpiration to make a quantitative evaluation of the morement of water in those phases of the hydrologic cycle in any drainage basin, except for a few experimental watersheds.

The records collected to date show everywhere marked changes from day to day, from season to season, from year to year, in the quantities of water passing through each phase of the hydrologic cycle. They also show that some communities, some states, are habitually more favored than others in water resources. The long-term average conditions, rather than the short-term fluctuations, are the limiting factors in the sound development of the water resources. The following paragraphs stress those average conditions within various geographic subdivisions of the country, in order to point out the areas chronically deficient in water supplies, where water becomes the limiting factor in economic development. As is shown later, the regional water deficiency-as against what civilization might consider desirable-applies to ground water as well as to other phases of the hydrologic cycle.

THE GROSS WATER SUPPLY: PRECIPITATION

Precipitation is measured and recorded at about 10,000 points distributed throughout the United States. It is recognized that existing data are inadequate for many regionsparticularly the sparsely inhabited mountainous and desert areas-and the network of stations is being extended every year. The records from these stations form the basis for computations of the gross water supply of the Nation. A summary of records from 5,000 stations for the 40 years from 1899 to $1938^{1}$ shows that the arerage precipitation over the Nation was about 30 inches; it exceeded 20 inches throughout the eastern half of the country, along the northwest coast, and in

1 Kincer, J. B., Climate and Weather Data for the United States, in "Climate and Man," U.S. Dept. Agri. Yearbook, p. 711, 1941. 
isolated mountainous areas throughout the west. The remainder of the western United States constitutes the arid and semiarid region where precipitation is perennially insufficient to sustain most crops. Figure 1 shows the areas where average annual precipitation is less than 20 inches.

\section{THE SURPLUS: STREAM FLOIV}

Stream flow is measured at more than 6,000 gaging stations. These gaging stations provide a quantitative measure of the visible outflow from the drainage-basin tributary to a stream at the point of measurement, as distinguished from the sampling methods that must be used for determinations of precipitation upon an area. Records show that the runoff from an area is nearly always less than the precipitation upon that arca: for the United States as a whole about 81/2 inches, or 28 per cent, of the average annual precipitation is carried by streams to the oceans. In Fig. 2, the areas where the average annual runoff is less than 1 inch are all in the western half of the country; for the most part they are similar to those areas shown on Fig. 1 as receiving less than 20 inches of precipitation a year. The higher mountains and plateaus form humid "islands" in this broad arid region, from which streams flow out upon the arid lands.

THE RETURN TO THE ATMOSPHERE: EVAPOTRANSPIRATION

Instruments have not yet been perfected to measure the return of water from the earth to the atmosphere, and there is no adequate means of knowing the distribution of evapotranspiration in space or time. The difference between precipitation and runoff provides an estimate of the evapotranspiration, which may, however, be considerably in error if there are significant changes in storage of soil moisture, ground water, or surface water during the period. For the nation as a whole it has been estimated that about $211 / 2$ inches of water, or 72 per cent of the average precipitation, is returned to the atmosphere annually by evapotranspiration.

Thornthwaite has pointed out the significance of "poten- 


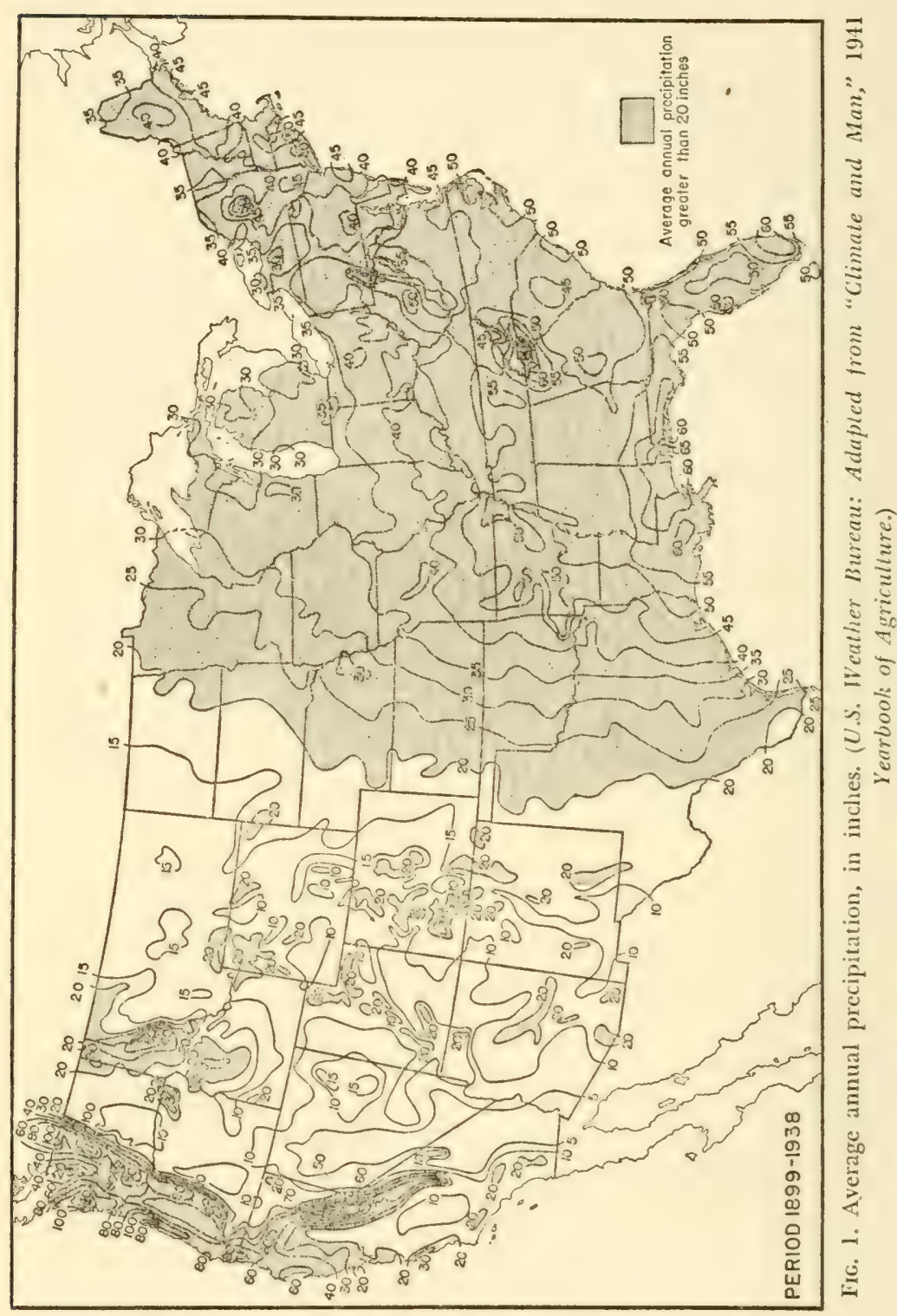



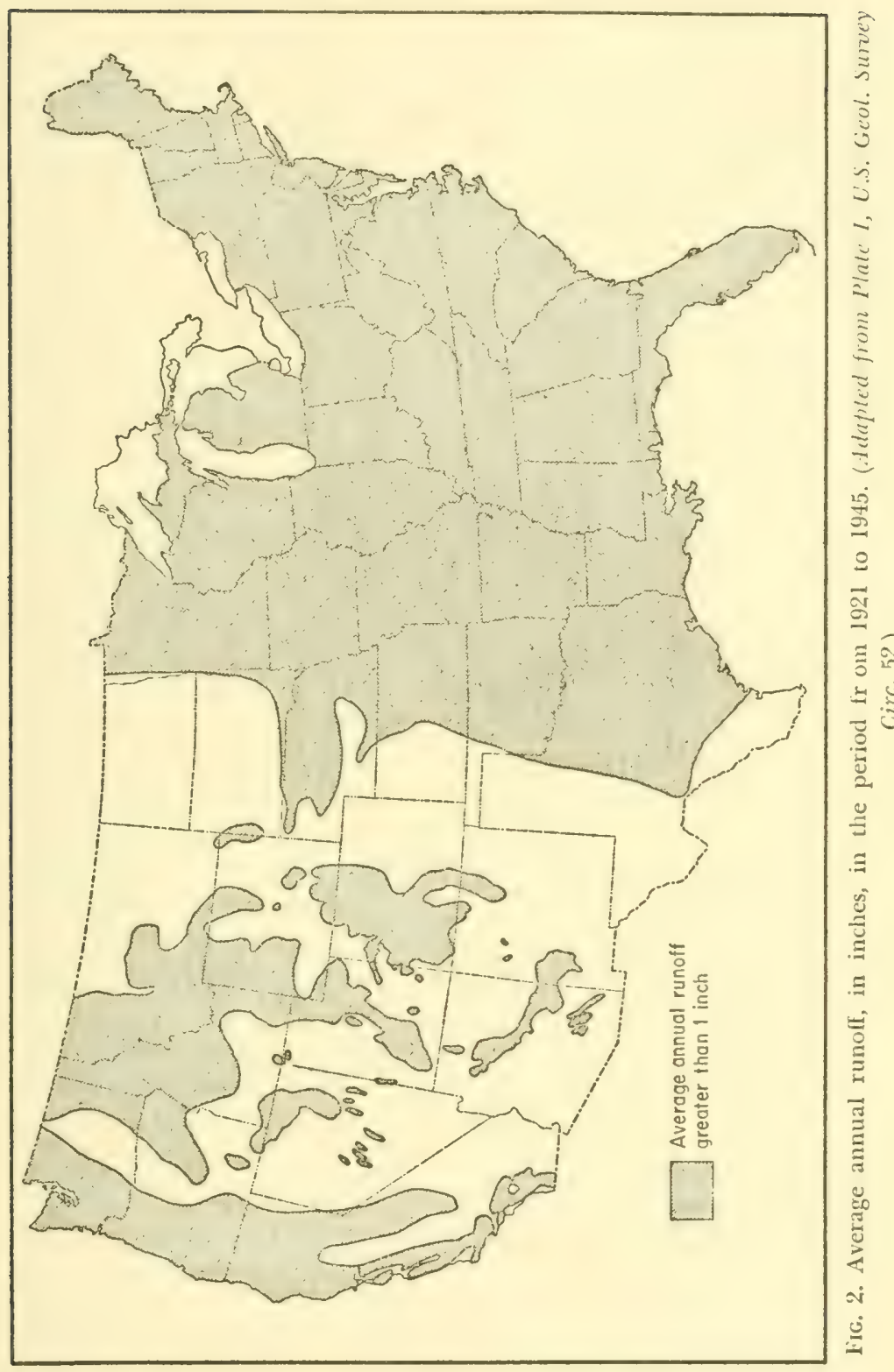
tial evapotranspiration" as a climatic factor in the following description: ${ }^{2}$

The vegetation of the desert is sparse and uses little water because water is deficient. If more water were available, the vegetation would be less sparse and would use more water. There is a distinction, then, between the amount of water that actually transpires and evaporates and that which would transpire and evaporate if it were available. When water supply increases, as in a desert irrigation project, evapotranspiration rises to a maximum that depends only on the climate. This we may call "potential evapotranspiration," as distinct from actual evapotranspiration.

We know very little about either actual evapotranspiration or potential evapotranspiration. We shall be able to measure actual evapotranspiration as soon as existing methods are perfected. But to determine potential evapotranspiration is very difficult. Since it does not represent actual transfer of water to the atmosphere but rather the transfer that would be possible under ideal conditions of soil moisture and vegetation, it usually cannot be measured directly but must be determined experimentally. Like actual evapotranspiration, potential evapotranspiration is clearly a climatic element of great importance. By comparing it with precipitation we can obtain a rational definition of the moisture factor.

It has been found that when adjustments are made for variation in day length, there is a close relation between mean monthly temperature and potential evapotranspiration. Study of all available data has resulted in a formula that permits the computation of potential evapotranspiration of a place if its latitude is known and if temperature records are available.

Where precipitation is exactly the same as potential evapotranspiration all the time and water is available just as needed, there is neither water deficiency nor water excess, and the climate is neither moist nor dry. As water deficiency becomes larger with respect to potential evapotranspiration, the climate becomes arid; as water surplus becomes larger, the climate becomes more humid.

Thornthwaite's areas of dry climates-in which the potential evapotranspiration exceeds the average annual precipita-

2 Thornthwaite, C. W., An Approach toward a Rational Classification of Climate, Geog. Rev., vol. 38, pp. 56, 63, 75, 1948. 
tion-are somewhat more extensive than the areas in which the annual precipitation is less than 20 inches. These areas are shown on Fig. 3. Also shown on this map are the areas of moist climates in which there is a summer water deficiency in average years-and in which therefore as a general agricultural practice it may be desirable to supplement precipitation by some form of irrigation.

\section{The Delineation of Arid and Humid Regions}

The areas in which precipitation is normally less than 20 inches a year (Fig. I) are also the areas which generate the least stream flow (Fig. 2). Annual potential evapotranspiration (computed on the basis of temperature) exceeds the precipitation over a somewhat larger area, and Thornthwaite shows that in addition there are humid areas where water is deficient in most summers (Fig. 3). None of those maps is complete; many of the western mountain ranges are not distinguished from the surrounding arid region because they are too small to show on these maps or because there are no data on precipitation or stream flow to indicate the climatic conditions. Several humid "islands" that appear on the map showing runoff are not included on the other maps because meteorological data are lacking for the higher parts of most mountain ranges.

All three maps confirm the existence of a large area of perennial water deficiency covering most of the western half of the country. Throughout this area the precipitation is ordinarily insufficient for agriculture, although border zones with semiarid climate may be successful dry-farming areas in some years. Generally, however, cultivated crops require irrigation, and the major sources of water for irrigation-whether from streams, springs, or wells_-are the humid mountain ranges. Water for municipal and industrial use in arid and semiarid regions is also obtained from the surplus produced in these humid areas. Thus the water resources of the mountain ranges are of critical importance to the economy of the West.

These maps portray average conditions, and the chance that 


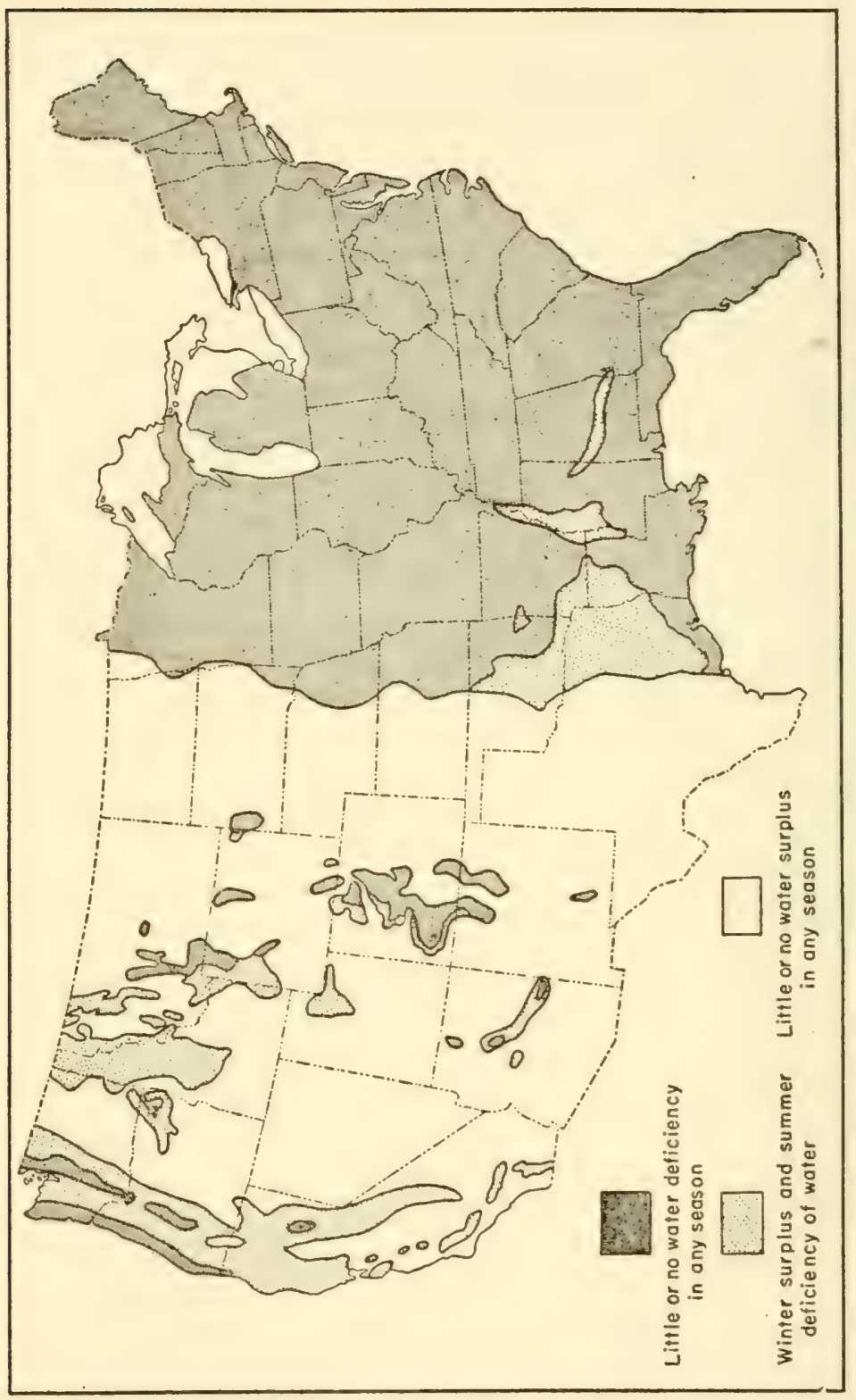

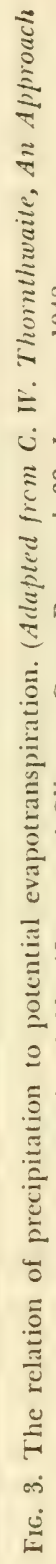


they will apply to the current year is no greater than the chance that the next person one meets will be of average height. Because of the vagaries of precipitation, far larger portions of the country may suffer from water deficiencies in some years, and on the other hand, the normally arid states may in some years develop moderate water surpluses.

\section{Nature's Great Reservolrs: Ground Water}

Although water is continuously passing on through the hydrologic cycle, man as a living thing must store enough or depend on natural storage to meet continuing or recurring demands. The major reservoirs of the hydrologic cycle are, of course, the oceans, which hold water unsuitable for most uses, but which, thanks to the energy of the sun, provide the great bulk of the fresh water falling upon the continents. ${ }^{3}$ Coastal areas worried about their water supplies have the comforting (though not very comforting) thought that whenever water becomes sufficiently valuable to justify the expenditure for energy, they can imitate this process and derive fresh water directly from the ocean. On the continent, the Great Lakes and many smaller fresh-water lakes form excellent reservoirs for communities in their vicinities, and the reservoirs created by man in all sections of the country serve to hold back the flood flows of streams for later use. Without such reservoirs, a stream cannot be counted on for more than the quantities available during periods of minimum flow-water that is derived largely from ground-water reservoirs.

Soil moisture constitutes a reservoir of major economic importance to agriculture. Water received by infiltration may remain in the soil for days or weeks, until it is used by plants or evaporated. Especially in humid areas this storage may be adequate for the needs of crops between rainstorms, but crops can experience shortage of water anywhere if the interval be-

3 Benton, G. S., R. T. Blackburn, and V. D. Snead, The Role of the Atmosphere in the Hydrologic Cycle, Trans. Am. Geophys. Union, vol. 31, pp. $61-73,1950$. 
tween rains is long enough. It has been amply demonstrated that man can increase the infiltration of water into the soil by conservation practices such as strip cropping, contour plowing, and terracing, and progressive farmers have found this augmented storage of especial value for maintaining crops in rainless periods.

Soil holds water by molecular attraction against the force of gravity. Only the excess above this field capacity moves downward to become ground water.

Ground-water reservoirs provide all the water yielded by wells and springs and constitute the source of the base flow of streams-the flow sustained throughout rainless periods. These reservoirs probably hold several times as much usable water as the combined capacities of all lakes and surface reservoirs, but we do not have enough information to provide a reliable estimate as to how much water is in them. Some examples provide an indication of the volume of water in storage in small areas of the country: it has been estimated * that the total volume of water that could be yielded by the ground-water reservoir under a 6,700-square-mile area in the Southern High Plains of Texas is about five times the capacity of Lake Mead, our largest surface reservoir. The alluvial valley of the Mississippi River below the mouth of the Ohio is estimated ${ }^{5}$ to contain about 1,000 cubic miles of alluvial material. The water in this saturated material need be only 13 per cent of the total volume, a reasonable or even a conservative figure, to equal the quantity discharged annually by the river into the Gulf of Mexico. (The Mississippi River discharges about one-third of the total runoff from the Nation's borders.)

The term "ground-water reservoir" is commonly used to designate the water-bearing material, or aquifer, from which

4 Barnes, J. R. et al., "Geology and Ground Water in the Irrigated Region of the Southern High Plains of Texas," Texas Board of Water Engineers, Progress rept. 7 , p. $41,1947$.

5 Fisk, H. N., "Geological Investigation of the Alluvial Valley of the Lower Mississippi River," Mississippi River Commission, pp. 17-18, 1944. 
man can extract water. Because there is usually movement of water through a ground-water reservoir, the connotation is not quite the same as for surface reservoirs, which are constructed to halt and accumulate the flow of streams. But movement underground is generally so slow, compared with that in streams or in the atmosphere, that it represents a definite retardation in the hydrologic cycle. Ground-water reservoirs thus provide slow-moving storage from which man may obtain water as he requires. If an analogy is permitted with the distribution system for manufactured goods, the ground-water reservoirs might correspond to giant warehouses in which the movement of goods in ton-miles is far slower than the rail, plane, or trucking phases of the system.

Nevertheless, an essential characteristic of ground-water reservoirs is movement of water through them. Most of the saturated materials underground are dense rocks, shales, clays, or glacial tills. They are not suitable reservoirs at all, as far as man is concerned, for they hold water in pores so small that it cannot be transmitted in usable quantities to wells or springs.

Wells will yield a perennial supply only to the extent that water can be transmitted to them through the entire course of the aquifer from the place where the water enters the ground. Even without wells, the ground-water phase of the hydrologic cycle is one of movement from the places where water enters the aquifer-the "recharge" areas-to the place where the water is discharged from the ground, either by evapotranspiration, by springs, or by seepage to streams or lakes or directly into oceans. Thus, as a rule, usable ground water does not remain at rest under a piece of land until the owner is ready to use it but is moving continually to some point of discharge at the surface.

DELINEATION OF GROUND-WATER RESERVOIRS OF THE UNITED STATES

This country unquestionably offers an endless variety of prospects for obtaining usable water from wells, both geo- 
graphically and in depth from which the water may be obtained. In each state are wells producing large quantities of water, others yielding only a few gallons a minute, and still others that have been abandoned because they penetrated nothing that would yield suitable water. Well drillers and well owners can outline areas respectively favorable or unfavorable for wells on the basis of knowledge gained from past drilling. Hydrologists have been able to apply this knowledge to many unexplored areas and predict the possibilities of derelopment there, but for large sections of the country data are lacking, and only the broadest of generalizations can be made as to the ground-water resources.

The occurrence of usable ground water is controlled in large measure by the geology, and some geologic formations are consistently better producers of water than others. But the geology alone is not enough. Some very permeable gravels, sands, or other rocks carry no water or are saturated with unusable water; some formations range widely in permeability even within short distances, and some contribute certain chemical or physical characteristics to the water which make it undesirable for specific purposes. Nevertheless the available geologic data constitute the only source of information concerning ground-water reservoirs in some parts of the country.

A map has been compiled to show the areas in which moderate to large supplies of usable water may be obtained from wells (see Plate I between pages 32 and 33). The map shows the areas where wells can yield 50 gallons per minute or more, sufficient to supply small municipalities or small industries, as distinguished from a well yielding only enough for stock or domestic uses. Water has generally been considered usable when it contains less than about 2,000 parts per million of dissolved matter, but some areas are shown where water of higher mineral content is actually being used.

The depth of the aquifer below the land surface was not taken as an essential criterion in the compilation of the map. However, inasmuch as most waters at great depth are highly 
mineralized, many deep sources do not qualify because of nonusability. Admittedly in some areas the depth may be too great for drilling under present economic conditions, but the water remains available whenever it is required.

In some areas water may be encountered at several depths, perhaps in more than one geological formation, but the map does not discriminate the areas occupied by individual aquifers. Instead, the map represents a composite of the important ground-water reservoirs and includes all areas through which significant quantities of usable water can pass through permeable materials.

The scale of the map and the extent of knowledge are insufficient to show this information in great detail. Successful large wells have been drilled in many small areas that could not be shown, and on the other hand satisfactory wells cannot be obtained at all points within the outlined "ground-water areas."

Three types of ground-water areas are distinguished on the map:

1. Watercourses, consisting of a channel occupied by a perennial stream, together with the enclosing and underlying alluvial material saturated with water that comes from the stream, from infiltration at the surface, or from adjacent water-bearing materials.

2. Loose water-bearing materials, chiefly gravel and sand, including the productive aquifers of the Coastal Plains, Great Plains, glacial drift and outwash, and western valleys. Buried glacial valleys not now occupied by perennial streams are included in this group. The areas shown include known and potential areas of well development as well as the recharge areas.

3. Consolidated water-bearing rocks, of which limestone, basalt, and sandstone are the most important. The areas include the recharge areas, which generally coincide with the areas of outcrop of the permeable rocks, as well as 
areas where the rocks are buried beneath less permeable materials but yield usable water to wells.

The blank areas of the map are significant because they indicate that about half the country is not known to be underlain at any depth by rock materials which can yield moderate quantities of water to wells. So far as known, the rocks underlying these blank areas are generally incapable of receiving or transmitting large quantities of water, either by infiltration from the land surface or from streams or by underflow from adjacent areas underlain by permeable rocks. These areas are of course not devoid of ground water, and many will yield adequate supplies for domestic or stock use. Dug wells in these areas may tap materials so impermeable that water drains into the well very slowly. The success of these wells is dependent largely upon the storage in the well itself, which permits pumpage of several hundred gallons at a time to meet occasional and limited demands. Because of the over-all low permeability of the rocks or overlying mantle in these areas, the ground-water phase of the hydrologic cycle carries a smaller than average proportion of the total water, and probably for shorter distances.

\section{CHANGES OF STORAGE IN A GROUND-WATER RESERVOIR}

An aquifer capable of yielding a perennial supply to wells, that is, where the water is a renewable resource, is an underground unit of the hydrologic cycle, with a recharge area higher than the area of discharge, so that water moves through the aquifer by the force of gravity. Generally the recharge areas are those where water can enter the aquifer from the land surface or from a stream bed by percolation through permeable materials. With additions from percolation, storage of water in the recharge area is increased, and the hydraulic gradient toward the discharge area also increases so that there is a greater rate of movement through the aquifer. Studies in many areas have shown how the water table-the top of the 


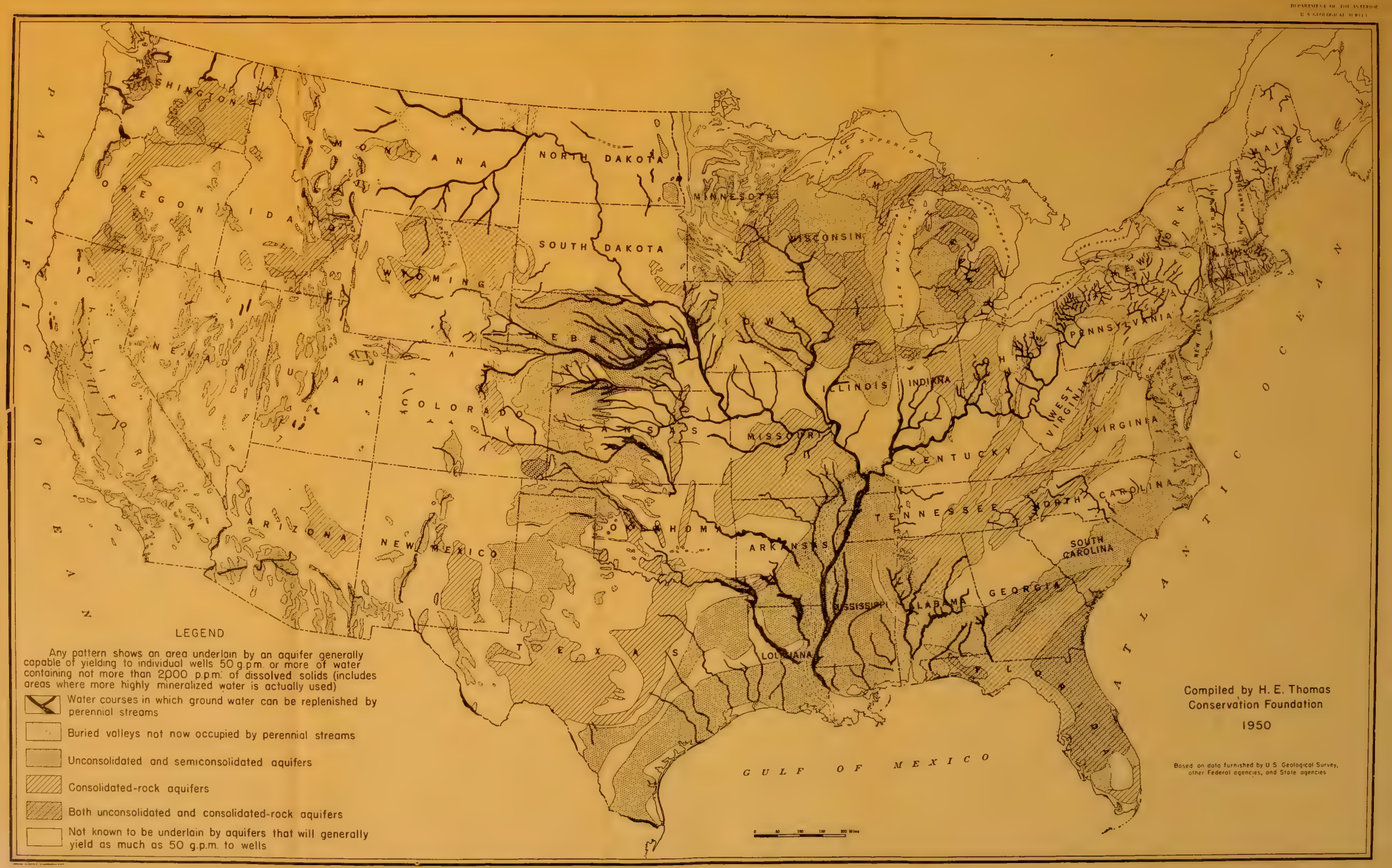



saturated zone-fluctuates in direct response to rainfall or to stream flow and to the movement of water toward the areas of discharge. Some ground-water reservoirs may be susceptible to recharge from the land surface over their entire area.

Portions of many aquifers are covered by relatively impermeable material, which not only impedes downward percolation of water from the soil zone but also confines the water within the aquifer. Commonly the confined water has moved laterally from areas where the confining layer is not present and where it has moved into the aquifer by percolation from the surface. Water so confined may develop sufficient artesian pressure to cause it to rise above the bottom of the confining layer or even to flow at the land surface if that layer is punctured by a well. Under these artesian conditions the rate of movement at any point fluctuates with the changes of pressure gradient, which in turn may reflect changes in storage in the recharge area or changes in rates of discharge. The storage of water in these artesian portions of an aquifer remains relatively constant as long as the aquifer remains "full." However, slight changes result from changes in pressure, and these slight storage changes may represent considerable volumes of water in an aquifer extending over many square miles.

Discharge from a well, whether by pumping or artesian flow, inevitably lowers the water table or artesian pressure in the vicinity. If by this lowering the water is diverted from a point of natural discharge, or if a greater amount of water is induced to enter the recharge area to replace the water withdrawn, the well can take its place in the natural circulating system and yield water perennially. Thus a declining water table or artesian pressure is not necessarily a cause for alarm.

Most instances of declining water levels result directly from ground-water development. Some indicate marked depletion in storage in a ground-water reservoir; others have developed in reservoirs which show no evidence of over-all depletion in storage and result from the inadequate capabilities of the rock materials to transmit the water quickly enough to the points 
where man wants it delivered. The problems resulting from ground-water development are summarized in the next chapter.

Man has succeeded in changing the storage in ground-water reservoirs by other means than pumping from them. These other means are concomitant with the development of cities, agricultural lands, surface-water supplies, navigation channels, etc.; for the most part they have probably been unintended and unforeseen. They are described briefly in a succeeding chapter. 


\section{PROBLEMS RESULTING FROM GROUND-WATER DEVELOPMENT AND USE}

The problems resulting from ground-water development, by means of wells, are alike in one respect: there is not enough usable water where it is wanted. The places where problems have arisen, including those where a satisfactory solution has subsequently been found, are so numerous and widely distributed that hardly a state is exempt. The occurrence of these problems is not tied closely to the general adequacy of the water supplies in the several states. Nevada, with the least precipitation and runoff of any state, has only one area (Las V'cgas Valley) where there are indications of overdevelopment. In contrast, Louisiana has heavier precipitation than most states and also flanks the Mississippi River, which carries one-third of the total runoff from the country; yet there have been several instances of failing ground-water supplies for municipalities, and there is evidence that heavy pumping for rice irrigation may eventually bring salt water into some wells.

Problems resulting from ground-water development are similar in many respects to those of city water systems. Some are due to inadequacy of the ground-water reservoir to meet the demands made upon it, which is analogous to the current difficulties of New York City with its surface-water reservoirs. Such reservoir problems are concerned with total water supplies, and if a ground-water reservoir is not replenished in sufficient quantity to meet the demand, the problem is one of real shortage of ground water. 
Pipeline problems may develop in any ground-water reservoir, due to inability of the water to move rapidly enough through the aquifer to meet the demand of specific wells or well fields. The problem is analogous to that of distribution systems afflicted with inadequate pipelines or distribution mains, which will give trouble even where the total supply of water is adequate. In ground-water reservoirs, as in watersupply systems, there are also problems of loss by wastage or leakage and problems of contamination of the supply by polluted water.

The watercourse problems are those where the groundwater and surface-water resources are so intimately related that they must be considered a single hydrologic unit.

\section{Reservorr Problems}

\section{RESERVOIRS IN WHICH NATURAL REPLENISHMENT IS INADEQUATE FOR CURRENT USES}

The areas of serious ground-water shortage are those in which wells, year after year, draw water from the groundwater reservoirs in excess of the annual replenishment. If a lake or surface reservoir were drawn upon similarly, the effect would soon be visible in the lowered lake levels and eventual draining of the entire reservoir. The effects are not so readily apparent in a ground-water reservoir, because the total water stored in it may be cnough to supply the wells for several decades, but the removal of that water will be evidenced by progressive lowering of water levels in wells throughout the reservoir area.

The ground-water reservoirs in which the draft in 1949 is considered to be in excess of average natural replenishment are shown on Plate II. Perennial overdraft is indicated in more than 30 important ground-water reservoirs, but in several of these the overdraft has been reduced by corrective measures. Nearly all these are in the arid regions (see Figs. 1 to 3) where all water supplies are deficient. It is altogether possible, in 
view of the likelihood of continually increasing requirements for water, that similar shortages may develop in the humid regions, but few areas in the eastern half of the country can yet be included in this group.

In some areas, a continuation of present rates of pumping will eventually empty the groundwater reservoir; in others, unusable water will be drawn into the reservoir as the good water is pumped out. In many areas, corrective measures have been undertaken to bring the draft and replenishment into balance.

PERENNIAL OVERDRAFT AND EMPTYING RESERVOIRS. Several ground-water reservoirs in the arid Southwest are being drawn upon at rates far greater than the average annual replenishment. Of these, there are some in which it is not likely that unusable water will be drawn in. The Santa Cruz Valley in Arizona, Antelope Valley in California, and Mimbres Valley in New Mexico are typical of areas with appreciable groundwater replenishment but where current pumping is so great that emptying of the reservoir is proceeding apace.

Santa Cruz Valley of the Gila River Basin, Ariz. ${ }^{1}$ About one-third of all the water pumped from wells in Arizona is withdrawn in the Santa Cruz Valley, which extends from the international border at Nogales northward past Tucson and thence northwestward to the Gila River. Heary pumping for irrigation started in 1914 in some places and has been more or less continuous since, but the rate of development has been accelerated since 1942 .

Total pumpage from the basin is computed to have been about 420,000 acre-feet $^{2}$ in $1941,730,000$ in 1945 , and

1 Reference: Turner, S. F., et al., "Ground-water Resources of the Santa Cruz Basin, Ariz.," U.S. Geol. Survey, Mimeo. repts., May 1943, 84 pp.; March 1947, 45 pp.

2 The common unit of water measurement in the West, and for irrigation generally, is the "acre-foot," which is equal to 325,851 gallons. In the East, and for municipal and industrial supplies generally, the common unit is "millions of gallons per day." To convert annual use, in thousands of acre-feet, to average daily use, in millions of gallons, multiply by a factor of 0.9 . 
$1,250,000$ acre-feet in 1949. These quantities are far larger than the computed average annual replenishment to the ground-water reservoir, which is derived chiefly by percolation from the river and tributary washes and from irrigated lands; there is little or no recharge directly from precipitation on the valley. The average annual flow of the Santa Cruz River at Nogales in the past 20 years has been about 15,000 acre-feet. The average replenishment of the groundwater reservoir from all sources, as computed in 1942, is of the order of 215,000 acre-feet.

The evidence of overdraft and of progressive depletion of storage in the ground-water reservoir is contained in the records of water levels in wells. Progressive declines have been noted in wells distributed throughout the basin, and the declines have been most pronounced in areas of concentrated draft, particularly where there is little recharge. As an outstanding example, water levels in the Eloy area have dropped 50 feet on the average in the period 1940 to 1949.

Pumpage has increased from about 275,000 acre-feet in 1945 to about 500,000 in 1949, when it was estimated to have been about 20 times the recharge. The Eloy area was declared a "critical area" by the state land commissioner in 1948, shortly after Arizona's ground-water law was passed, and since then increased withdrawals have not been permitted, whether from existing wells or new wells. However, this regulation does not extend to other parts of the Santa Cruz Valley from which the ground water in the Eloy critical area must be replenished, nor does it provide any means for bringing the present pumping draft down toward the estimated rate of natural replenishment.

The Santa Cruz is one of the tributaries of the Gila River, and the overdraft in the Santa Cruz Valley is just one of many pressing problems that must be solved in working toward full development of the "Central Arizona" area. As an example of the complexity of the problem of full basin development, the Santa Cruz Valley is bordered on the 
north by a reach of the Gila River where consumptive waste of water by tamarisk and mesquite was estimated in 1942 to be between 100,000 and 150,000 acre-feet a year. If this vegetation could be replaced with crops or other vegetation that uses less water, the water saved might serve to alleviate some of the shortage in the lower Santa Cruz Valley. Such salvage would involve both technical and legal problems in connection with established rights to the water in the Gila River.

The proposed central Arizona project of the Bureau of Reclamation includes the lower part of the Santa Cruz Valley as one of the areas where supplemental water would be imported from the Colorado River.

Antelope Valley, Calif. ${ }^{3}$ Antelope Valley lies north of the San Gabriel Mountains and only about 75 miles north of Los Angeles. Although the setting is real desert, ground water appeared to be inexhaustible in 1910, when several wells had artesian pressures of more than 10 pounds per square inch and flowed 900 gallons a minute. Many wells had ceased flowing by 1920, however, and since then more and more wells have been pumped for irrigation. Today about 110,000 acre-feet is pumped annually.

The total replenishment in recent years is estimated to have averaged about 65,000 acre-feet annually, and water levels in wells have been declining at a rate of about 3 feet a year, because of overdraft. The Owens Valley aqueduct to Los Angeles crosses the valley, and in some years as much as 7,000 acre-feet of water has been released within the valley to augment the natural replenishment of the groundwater reservoir. The valley has large underground storage capacity and a great expanse of land suitable for irrigation if more water were available.

In the San Jacinto Basin, also in the desert region of

3 References: Gleason, J. B., "Antelope Valley, South Coastal Basin Investigations," Calif. Div. Water Res., Unpublished data.

Calif. Div. Water Res., Personal communication. 
southern California, pumping is perennially greater than replenishment. This basin is somewhat similar to Antelope Valley. Recent studies indicate that current pumping is at a rate of about 250,000 acre-feet a year, and about 43,000 acre-feet more than the average annual replenishment.

Mimbres Valley, N. Mex. ${ }^{4}$ The Mimbres Valley is a closed basin in southwestern New Mexico. Beginning in 1923, pumpage for irrigation has steadily increased to 10,000 acrefeet in 1934, 21,000 in 1941, and 58,000 in 1948, when about 24,000 acres was irrigated by ground water. Water levels had declined as much as 30 feet in some wells by 1939, and more than 8 feet in an extensive area. From 1942 to 1949, water levels have declined more than $10 \mathrm{feet}$ in an area of 10 square miles, an accelerated rate that ties in well with the increased rate of pumping.

Some wells east of the Florida Mountains were abandoned as water levels reached the base of the aquifer, but there is still much ground water in storage in the rest of the basin.

The natural replenishment comes chiefly from the Mimbres River and has probably diminished in recent years because of increased use of the stream for irrigation. It has been estimated that the average annual replenishment is about 10,000 acre-feet, and that in the wet year 1941 it may have approached 15,000. Thus, in the past decade, the bulk of the water pumped for irrigation has been taken from storage.

Many ground-water reservoirs in arid regions are not replenished in dry years. In the driest basins, the ground-water reservoir may receive no recharge in a year of "normal" precipitation, because all the moisture is dissipated from the soil zone. Recharge to these reservoirs occurs only during years of exceptionally abundant rainfall, which may mean only one

4 Reference: Theis, C. V., Progress Report on the Ground-water Supply of Mimbres Valley, New Mexico, N. Mex. State Eng. 12th-13th Bienn. Rept., pp. 135-154, 1938. 


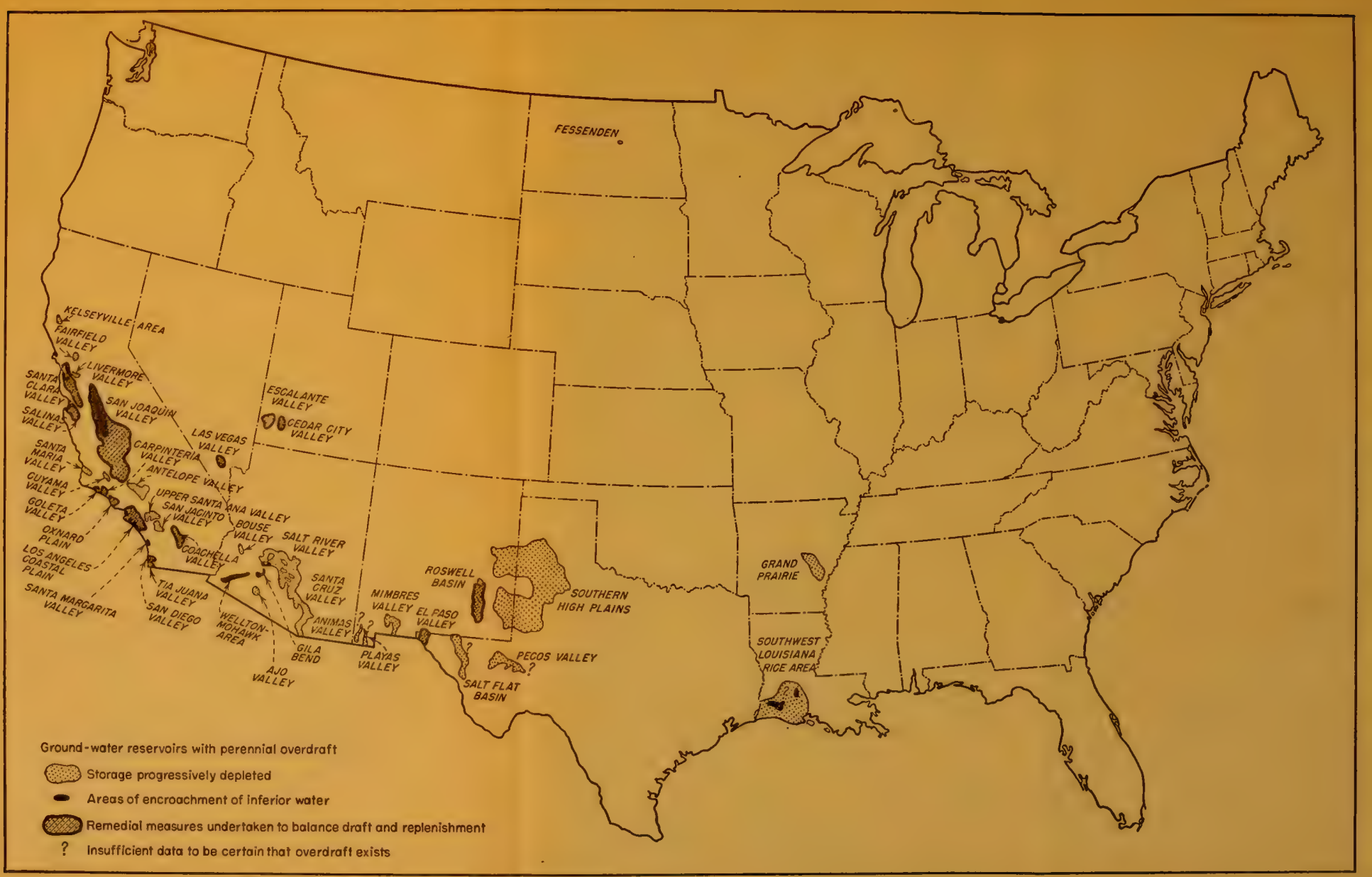

Pl.ATE II 

in 5 or 10 years or longer. Development of these reservoirs for perennial water supply must be on a trial-and-error basis in the absence of hydrologic records covering many decades. The annual draft must be less than the quantity replenishing the reservoir in occasional wet years, because some of that quantity should be held for use in years when pumping must be largely from storage.

Because of the variation in rate of recharge from year to year, judgment as to whether wells are drawing more from a reservoir than is being replenished should be based on records for many years. In same desert basins, replenishment may occur so rarely and in such small quantities as to be considered negligible.

Sonoran Desert of Arizona and California. ${ }^{5}$ In several parts of southwestern Arizona and southeastern California, the evidence of negligible recharge to ground-water reservoirs is based in part on the reports of reconnaissances for desert watering places. These are the basins in which there are very few springs or other evidences of ground-water discharge and in which the water table nearly everywhere is far below the land surface. Precipitation over the drainage basin is so scant that it could conceivably be dissipated entirely by evapotranspiration from the soil zone, and it is reasoned that if there were periodic accretions to the ground-water reservoir, there would have been accumulation during past decades and centuries that by now would have filled it to a level where discharge could occur.

For example, Ivanpah Valley, a closed basin in California near the southern tip of Nevada, receives very little recharge to its ground-ivater reservoir from the meager precipitation

5 References: Thompson, D. G., The Mojave Desert Region, U.S. Geol. Survey Water Supply Paper 598, p. 608, 1929.

Barr, A. T., and E. C. Sandberg, "The Part Water Plays in Mining," New Cornelia Branch, Phelps-Dodge Corp., Ajo, Ariz., Mimeo. rept., 1941, 16 pp.

"Ground Water in Bouse Valley, Ariz.," U.S. Geol. Survey rept., in preparation. 
over the low drainage basin. Ground water is everywhere more than 75 feet below the surface, and there is no evidence of ground-water discharge from the basin.

One of the most important industries in the Sonoran Desert area is the mining and milling of the low-grade copper ores at Ajo, Ariz. The Phelps-Dodge properties there in 1940 required about 240 gallons of water per ton of ore mined, of which about three-quarters was used in concentrating the ore. To meet these requirements, the company pumps several million gallons a day from a "water mine," consisting of two shafts and several thousand feet of drifts in permeable lava more than 600 feet below the land surface.

Although there may be some replenishment from torrential rainstorms over the higher parts of the drainage basin, the quantity recharged is far less than the withdrawals; since large-scale operations commenced in 1917, a considerable rolume of the aquifer has been unwatered by extension of drifts and by pumping from deeper levels. Thus, there has been a depletion of water reserves by mining more or less comparable to the depletion of copper reserves.

Farther north in Arizona, pumpage of water for irrigation is increasing in Bouse Valley and Centennial Valley, where preliminary recomnaissance indicates that replenishment to the ground-water reservoirs may be so low as to be considered negligible.

The valley ground-water rescrvoirs of the West are typically bordered on two sides and sometimes completely enclosed by mountain ranges, from which both the water and the waterbearing material are generally derived. In many instances one range is far higher than the other and furnishes the great bulk of the water to the valley. As a result, the water from one side may saturate the valley materials clear to the base of the unproductive range on the other side, as is the case in Utah Valley in Utah. Commonly, however, the sediments in the central 
part of the valley are too fine or other conditions are unfavorable for movement of water across the valley, and the "dry" side thus receives negligible recharge. This is the situation in San Joaquin Valley, Calif., where the pumping for irrigation on the west slope is almost entirely from storage, and water levels in wells have declined markedly as a result.

West Slope of San Joaquin Valley, Calif. ${ }^{6}$ Practically all the replenishment to the ground-rvater reservoir of San Joaquin Valley comes from the numerous streams that drain the Sierra Nevada and thus enters the eastern part of the ground-water reservoir. The ground waters along this eastern slope are of different chemical character from those under the west slope. The streams of the west slope are small and dry a good part of each year; several carry enough obnoxious chemical constituents to make the water undesirable for irrigation. The ground-water reservoir under the west slope receives little water from these streams and local precipitation. The contribution from the more abundant supplies of the east slope is considered nil.

In comparison with the recharge, the pumpage from wells on the west slope is very large. It is estimated that about 1 million acre-feet, or one-seventh of the total in the valley, was pumped from west-side wells in 1949. Water levels are falling at a rate of 10 to 20 feet a year, and pumping levels are 300 to 400 feet below ground surface in most of the irrigated area.

Commonly there are three zones of water-bearing formations under the west slope, of which the upper and lower are generally strongly saline. The usable middle zone, which

6 References: Ewing, F. A., "Irrigation and Drainage in San Joaquin Valley, California," U.S. Soil Cons. Serv., Mimeo. rept., 1946, 80 pp. Forbes, Hyde, Geology of the San Joaquin Valley as Related to the Sources and Occurrence of Ground-water Supply, Trans. Am. Geophys. Union, vol. 22, part I, pp. 8-20, 1941.

Ingerson, I. M., "Ground-water Conditions in California," Presented at Conference of Agricultural Extension Service, University of California, February 1949. 
is tapped by most wells, is thus confined between bad waters. Many wells are perforated in both upper and middle aquifers for the purpose of drawing some water from the upper horizon and diluting it with the more usable water that comes from below. Needless to say, this construction provides means of access of bad water into the heavily pumped middle zone when the wells are idle.

It is possible that the reservoir can eventually be recharged artificially through wells, but the methods attempted to date have not been successful. If the present irrigation economy is to be perpetuated, it appears that water must be imported from other areas.

A few ground-water reservoirs receive very little replenishment because of unfavorable geologic conditions. There undoubtedly are some reservoirs where the water was accumulated long ago and is now trapped with little opportunity for either recharge or discharge under present conditions. Entrapment of water in rocks is not uncommon, and there are numerous localities where water has remained in rocks since their deposition. Connate water has been encountered in many wells, but generally it is saline and unusable, a remnant of the sea in which the rocks were deposited. Some ground-water reservoirs may contain fresh water entrapped since the deposition of the rock materials, but no specific examples are yet recorded.

Several reservoirs contain appreciable amounts of water in storage but are prevented from receiving more than negligible recharge by enclosing or overlying impermeable materials. The waters in such reservoirs may be exceptions to the rule that ground water is a renewable resource, for the aquifers obviously cannot be counted on for perennial supply. It is inevitable that the reservoirs will be depleted when wells pump from them. The examples cited below are remarkable for their contrasts: in the Drift Prairie the aquifers hold only small quantities of water, but in the High Plains and the Grand Prairie there is a vast amount of water stored under- 
ground; in the Grand Prairie area there is abundant precipitation, but the Drift Prairic and High Plains are semiarid. One feature in common, however, is the existence of impermeable clayey material that prevents significant recharge. Such conditions, though rare, can occur in humid as well as arid regions.

Southern High Plains of Texas and New Mexico. ${ }^{7}$ By prodigious development in the past four years, the Southern High Plains now ranks fourth in the United States in usage of water from wells. In 1949 the pumpage was of the order of 1,250,000 acre-feet from 12,000 irrigation wells-about the same amount of water as is normally used by New York City's 8 million inhabitants. By contrast the pumpage in 1935 was about 50,000 acre-feet, about half in Texas and half in New Mexico. In the ensuing 14 years the pumping in New Mexico has increased fivefold, but the great expansion-to more than 40 times the rate of pumping in 1935 has been in Texas. This expansion has occurred chiefly in a 6,700-square-mile area, embracing parts of 17 counties.

The Southern High Plains receives about 20 inches of precipitation a year on the average, of which 70 per cent falls during the growing season. In exceptional years, as in 1941, rainfall is sufficient and properly distributed for growing crops without irrigation. In most years some irrigation is beneficial as a supplement to the summer rains, but the average annual requirement is only about 1 acre-foot per acre in the Texas area, far less than is required in most irrigated areas of the arid Southwest. More than 99 per cent of the annual precipitation is returned to the atmosphere from the soil zone, which is seldom moist to any great depth. Even during periods of prolonged storms and exces-

7 References: Barnes, J. R., et al., "Geology and Ground Water in the Irrigated Region of the Southern High Plains of Texas," Texas Board of Water Engineers, Progress rept. 7, 1949, 51 pp.

Frye, J. C. and V. C. Fishel, "Ground Water in Southwestern Kansas," State Geol. Survey Kans., 1949, 24 pp.

"Oklahoma Waters," Oklahoma Planning and Resources Board, Photolith rept., pp. 118-120, 1945. 
sive rainfall, recharge to the ground-water reservoir is inhibited in most of the so-called "hard lands" by widespread clay subsoils or by cemented caliche zones, and the water from precipitation is dissipated instead by evaporation from the soil zone and from numerous ponds and lakes that form in depressions, or to a small extent by stream flow. The principal areas of recharge are sand hills and small areas of sandy soil.

It is estimated that because of this combination of climatic and geologic factors, recharge to the ground-water reservoir is of the order of 50,000 acre-feet a year-about 4 per cent of the current rate of pumping. Rainfall upon the High Plains is the only source of water in the underlying sands and gravels. There is no possibility of natural recharge from the Rocky Mountains, the Pecos River, or the Canadian River.

The natural discharge of ground water from springs and seeps along the east border of the High Plains-perhaps 50,000 acre-feet a year-has not yet shown any obvious diminution as a result of the great withdrawals of water from wells in recent years. Thus, practically all the water pumped to date has been from storage within the aquifer. The total water still in storage is estimated to be of the order of 150 million acre-feet, of which nearly two-thirds is believed to be within 200 feet of the land surface. It is evident that the storage would be sufficient for many decades of withdrawal at present rates, if the wells were properly distributed over the High Plains.

If the ground-water reservoir were emptied, it would take some 30 centuries to refill at present-estimated rates of natural recharge. But the present development has not been planned with a view toward scientific extraction of water over a period of several decades. Pumping from 1938 to 1949 lowered the water table more than 10 feet over more than half of the 6,700-square-mile pumping district in Texas; concentrated draft near Lubbock and Plainview caused a decline of more than 10 feet in an area of 10 square miles. In these areas of concentrated draft, the storage in the 
ground-water reservoirs will be depleted in a relatively short time. Everywhere in the High Plains continued withdrawal will be at progressively increasing cost in pumping lifts.

In the Northern High Plains in the Texas Panhandle north of the Canadian River, there has been a notable increase in pumping since World War II, and pumpage in 1949 was of the order of 60,000 acre-fect. Although the conditions here are basically similar to those of the Southern High Plains, pumpage is so much less that the area has not developed critical problems. In Oklahoma and Kansas, the High Plains is similarly underlain by permeable gravel and sand with large quantities of ground water in storage. The estimated average recharge, however, is greater than in Texas, especially in the large sand-dune areas where infiltration of water from precipitation is high. Relatively little water is being pumped from these aquifers at present, and there has been no pronounced decline of water levels in wells in the past 70 years, except in places such as Scott County in Kansas where there has been heavy pumping from wells concentrated in a small area. In fact, the High Plains is regarded as one of the most promising areas for potential development in both states.

Still farther north, in Nebraska, the average rate of replenishment to the principal aquifers of the Great Plains is even greater, especially in the Sand Hills where those aquifers include or are overlain by highly permeable sand dunes. Ground water in the Sand Hills has not been developed for irrigation because the surficial materials are too permeable for cultivation, and the land is used primarily for grazing and wild-hay production.

"Drift Prairie" of the Dakotas. ${ }^{8}$ Many towns and hundreds of farms in North Dakota obtain their water supplies

8 Reference: Filaseta, Leonard, "Ground Water in the Fessenden Area, Wells County, N.D.," Progress rept., N.D. Geol. Survey, Mimeo. rept., 1946, 22 pp. 
from wells that tap thin lenses of sand and gravel in the glacial drift. Some lenses are so thin that their initial yield is insufficient for a farm dwelling; others carry enough water to supply a town of several hundred for years. Many of these aquifers are completely enclosed in impervious glacial till, and when water is pumped from them there is no evidence of the replenishment that is required for a perennial supply.

The situation in Fessenden, N.D., is an example. Under that town there is a sand and gravel lens having an areal extent less than 100 acres and a maximum thickness of about 30 feet. Wells in that aquifer supplied the water for the town for 20 years, but only the lower 14 feet of aquifer was still saturated in 1939, and by 1945 all but a 3 -foot thickness had been unwatered. In 1941, another sand lens 19 feet thick was located 5 miles northeast of town by test drilling; initially producing 100 gallons a minute, the yield had dropped to 10 gallons a minute by 1944 , when there remained only 7 feet of saturated sand. In 1945, the town was obtaining only about 20,000 gallons from these two wells, and hauling 15,000 gallons from the town of Heimdal, 12 miles away. Subsequently another aquifer was discovered 7 miles north of Fessenden and was producing about 70,000 gallons per day in 1950 .

The rates at which these aquifers are unwatered suggests that practically all the water is taken from storage-water that may possibly have been in the sand since the glacial epoch. Water in such aquifers constitutes a nonrenewable resource, comparable to petroleum, and the technique of maintaining a perennial supply is similar--prospecting and locating additional aquifers for utilization as fast as the developed sources are depleted. It is possible that there is slow replenishment of unwatered aquifers from the enclosing clay, so that they may be refilled and usable again in several decades. In general, the inhabitants of the area make every effort to locate other and more permanent sources of supply: gravel in present stream valleys or in buried glacial channels, 
permeable glacial outwash at shallow depths, or perhaps the highly mineralized water in the deeply buried Dakota sandstone (see page 101).

Grand Prairie, Ark. ${ }^{9}$ Rice has long been one of the principal cash crops in the state of Arkansas, and most of the state's crop is produced on upland terraces of the Mississippi River alluvial plain in an area extending along the east side of the state from its northern to southern boundary.

Typical of the rice-producing area is the Grand Prairie, between the White and Arkansas Rivers, some 20 to 60 miles east of Little Rock. Rice growing was begun there on a commercial scale in 1904, and in irrigated area increased to 100,000 acres by 1915 , and 160,000 by 1942 ; by 1949 , despite the ever-increasing acreage of rice in other parts of the state, nearly half the total of 400,000 acres was in the Grand Prairie.

A large quantity of water is used for the irrigation of rice. The fields are flooded when the plants are 6 or 8 inches high, and standing water is maintained almost continuously for 2 or 3 months, until the crop is nearly mature. In 1949 about 250,000 acre-feet of water was pumped from wells for irrigation of rice on the Grand Prairie. The soils of the prairie are underlain practically everywhere by a "hardpan," consisting of compact clay so impervious as to inhibit downward percolation of water-practically made to order for the ponding required in rice growing. The clay in some places is more than 50 feet thick.

A ground-water reservoir in permeable sand and gravel, ${ }^{10}$

๑ Reference: Engler, Kyle, D. G. Thompson, and R. G. Kazmann, Ground Water Supplies for Rice Irrigation in the Grand Prairie Region, Arkansas, Univ. of Ark. Agr. Exp. Sta. Bull. 457, 1945, $55 \mathrm{pp}$.

10 Actually, only a part of a larger ground-water reservoir that extends from north to south across Arkansas, and into adjacent states. Thus, the Grand Prairie might be considered instead as an area of concentrated draft from a portion of a ground-water reservoir. The classification used here is recognized as tentative, pending fuller information. 
generally 50 to 150 feet thick, lies beneath the clay throughout the Grand Prairie.

Originally the water was under sufficient artesian pressure to rise 20 to 35 feet above the top of the aquifer, but so much water has been removed from storage by pumping that a considerable part of the aquifer has been unwatered. The aquifer had been partly drained under an area of 240 square miles by 1929, and by 1944 the unwatered material was computed to have an average thickness of $11 \frac{1}{2}$ feet in an area of 610 square miles. The reduction in storage, amounting to nearly $1,400,000$ acre-feet by 1944 , proves that pumping for many years has exceeded the replenishment to the aquifer under the Grand Prairie.

The ubiquitous clay prevents recharge within the ricegrowing area, either from precipitation or from irrigation, and the only replenishment is by movement of water from beyond the borders of the Grand Prairie. The White River along the northeastern border of the region is known to provide some recharge, and in a few places small sandy areas may permit some recharge to the aquifer. The initial hydraulic gradient was to the southeast, suggesting that water enters the aquifer northwest of the Grand Prairie. Since the development of the broad cone of depression by pumping, water has moved inward from all directions.

As more and more of the principal aquifer has been drained, an increasing number of wells have been drilled to deeper aquifers. Little is yet known about the capabilities of natural replenishment for these deeper wells, but there is a good chance that here again the wells will pump from long-accumulated storage, and the yield that can be perennially sustained will be less than the rate at which the wells can be pumped initially.

To sum up, the ground-water reservoir of the Grand Prairie is capped by impermeable materials ideal for ricegrowing but unsatisfactory for ground-water replenishment. The reservoir has large storage capacity, and as the water is removed by pumping, the utilization of that capacity be- 
comes more and more dependent upon finding ways of putting water into it. There is ample water available at some seasons in the White River and other streams, and an important question for research is whether large-scale recharge (probably through wells) is feasible, and, if so, whether manipulation of storage in the ground-water reservoir would be more economical than the construction of a reservoir on the White River or another stream, and diversion to the rice lands by canals.

The reservoirs that are being emptied pose real problems for their users. It is certain that as the storage is depleted and finally exhausted, the draft will necessarily be reduced to the amount of annual recharge, and the water users must then pump that water practically from the bottom of the reservoir. Particularly in the case of reservoirs with negligible recharge, those who have been relying on wells must abandon ground water as their source of supply and look elsewhere. The alternative to this disastrous future is to attempt to bring the draft and replenishment into balance. Corrective measures that have been applied are discussed subsequently.

THE COMPLICATION OF INTRODUCING UNUSABLE WATER. The drawing in of unusable water is generally a more serious problem than the "mining" that eventually results in emptying a ground-water reservoir. It may nccessitate abandoning wells while there is still plenty of water in the reservoir, owing to impurities that make it unfit for use. Furthermore, an emptied reservoir may fill again by natural processes if left alone; but dissolved chemical matter is difficult to remove, as the woman in our childhood reader found when she accidentally put a spoonful of salt in her coffee.

In several California valleys open to the occan, pumping from storage has progressed to the point where the water table or piezometric surface is now below sea level at the coast. Unless there is an impermeable barrier to prevent it, the ocean water can move into the ground-water reservoirs of those coastal valleys. Intrusion of saline water into reservoirs once 
occupied by fresh water has been reported along the shores of San Francisco Bay and in the lower part of the adjacent Santa Clara Valley; in the lower end of Salinas Valley; along the Los Angeles Coastal Plain from Venice to Newport Beach; and near Ventura, San Juan Capistrano, Oceanside, and San Diego. The coastal Goleta Valley near Santa Barbara is also pumping ground water below sea level but is protected from salt-water encroachment by a fault barrier.

Santa Clara Valley, Calif. ${ }^{11}$ The Santa Clara Valley embraces nearly 200,000 acres, of which 121,000 are irrigated lands and municipal areas within the Santa Clara Valley Water Conservation District. Practically all the water for irrigation, municipal, and industrial use is pumped from wells. In recent years more than 2,000 wells have pumped an estimated 210,000 acre-feet a year, which is believed to be about 35,000 acre-feet more than the average annual replenishment. In much of the valley area the ground-water reservoir is confined beneath a clay blanket and not susceptible to appreciable replenishment by downward percolation from the surface. The recharge areas for the groundwater reservoir consist of narrow, discontinuous belts of gravel and sand along the borders of the valley, and especially the permeable areas along the channel of Coyote River and its tributaries.

Pumping from wells for irrigation began in 1908 but until 1917 was generally less than the average annual replenishment. By 1918, the annual draft had climbed above 50,000

11 References: Hunt, G. W., Description and Results of Operation of the Santa Clara Water Conservation District's Projects, Trans. Am. Geophys. Union, vol. 21, part I, pp. 13-22, 1940.

Tolman, C. F., and J. F. Poland, Ground Water, Salt-water Infiltration and Ground-surface Recession in Santa Clara Valley, Calif., Trans. Am. Geophys. Union, vol. 21, pp. 7, 23-34, 1940.

Hunt, G. W., "Proposed Lexington Dam and Conservation Works," Report to Board of Directors of Santa Clara Valley Conservation District, 1947, 29 pp. 
acre-feet and has exceeded 100,000 acre-feet in most years since 1924. From 1916 to 1934, the average water level in wells dropped about 110 feet; the pumping draft exceeded replenishment in nearly every year, and it was estimated that more than 800,000 acre-feet of water was removed from storage in the ground-water reservoir. About 230,000 acrefeet of this water is considered to have been derived by slow drainage of silts and clays, with resulting compaction of those beds to the extent that the land surface was depressed over an area of about 200 square miles, and the subsidence reached a maximum of more than 5 feet in the city of San Jose.

As early as 1920, water levels were lowered below sea level by pumping, thus providing conditions favorable to encroachment of salt water from San Francisco Bay. Generally the clay blanket near the bay is sufficiently impervious to protect the underlying ground-water reservoir, but salt water has entered in places where the blanket is punctured. Abandoned wells have been the chief avenues of such encroachment, but some salt water evidently has entered through the gravels along stream channels. In some areas saline water has moved inland more than 3 miles from the tidelands of the bay.

The ground-water situation was sufficiently harassing by 1934 so that the Santa Clara Valley TVater Conservation District was formed for the purpose of harvesting waste floodwaters and recharging them into the ground-water reservoir. Records indicated that the runoff wasted to the bay in an average year was about 126,000 acre-feet, or more than half the total stream inflow to the valley. Dams to hold back floodwaters, percolating ponds, baffles in stream beds, diversion canals, and spreading grounds were constructed in 1935 and 1936. In the first 5 years of the District's operation, the natural percolation was reported to have been augmented nearly 80 per cent by these artificial aids, but more than half the stream flow was still lost to the ocean, chiefly in 1938 when 
heavy precipitation produced runoff far in excess of the capacities of combined natural and artificial percolating systems.

Thanks partly to a series of years of above normal rainfall and runoff, water levels in the valley rose more than 70 feet in the first 8 years of the District's operations. The combination of increased pumping draft and deficient rainfall since 1943 has reversed the trend, however. By 1949 the average water levels were only 15 feet higher than at the time of the record minimum of 1934, and the pumping lift exceeded $400 \mathrm{fect}$ in some wells. At present, the District is enlarging the facilities for storage and recharge of floodwater and thus will minimize the waste to the bay during years of abundant rainfall and runoff. As another possible source of additional water, studies are being made of the possibility of reclaiming the sewage effluent from the cities in the San Francisco-Oakland-San Jose metropolitan area. At present, this effluent amounts to about 250,000 acre-feet a year and is discharged into San Francisco Bay, contributing to the low-tide fragrance of the eastern approaches to the bay bridge.

Salinas Valley, Calif. ${ }^{12}$ The Salinas Valley floor covers about 239,000 acres, of which 177,000 is classed as irrigable. In $1945,127,000$ acres of this land was irrigated, almost entirely from wells. The total annual pumpage from wells in recent years has been of the order of 370,000 acre-feet, which is about 30,000 acre-feet more than the average annual replenishment. On the other hand, 530,000 acre-feet flows out from the valley to the Pacific Ocean in an average year, of which about 90 per cent is the winter flow of the Salinas River.

There are significant differences in opportunities for natural replenishment in different parts of Salinas Valley. Pumpage from the upper half of the valley has been of the 12 Reference: Simpson, T. R., Salinas Basin Investigations, Calif. Div. Water Res. Bull. 52, 1946, 230 pp. 
order of 210,000 acre-feet a year, but there is no overdraft; indeed, there is more than 100,000 acre-feet of water in storage within 60 feet of the surface, on which draft has never been made. This is the part of the ground-water reservoir most readily recharged by the Salinas River and its tributaries. On the other hand, along the lower east side of the valley, the pumpage of 35,000 acre-feet is about 7,000 acrefeet greater than replenishment, and the water table has been receding at an average rate of $1 / 3$ foot a year. Finally, in the "pressure area" comprising the lowest part of the valley, water is confined in aquifers under artesian pressure. The pumping draft of 120,000 acre-feet in the pressure area must be replenished by lateral movement from adjacent areas, and in recent years it is estimated that during the pumping season about 6,000 acre-feet of saline water has intruded into the "180-foot" aquifer from Monterey Bay.

If 5 per cent of the present surface outflow to the ocean could be salvaged and put to beneficial use, present overdrafts in the east side and pressure areas could be eliminated; and if 15 per cent of that outflow were salvaged, water would be available for the 50,000 acres of irrigable land not irrigated now. It has been proposed to pump water from the river gravels above the pressure area, divert it through canals, and recharge the east-side area, where there are unsaturated gravels capable of storing about 200,000 acre-feet of water. The gravels above the pressure area would be replenished from winter stream flow in normal years, and this salvage would be of material advantage in providing groundwater storage to tide over dry years. Salt-water encroachment in the lower pressure area can also be reduced by increasing the irrigation efficiency there, so as to eliminate all pumping in excess of beneficial requirement.

Several heavily developed ground-water reservoirs in southern California are in valleys from which streams discharge large quantities into the ocean during the winter. The Santa Maria, Cuyama, and Santa Ynez Valleys and the Oxnard Plain are like Salinas Valley in this respect. 
Los Angeles Coastal Plain, Calif. ${ }^{13}$ The Los Angeles Coastal Plain receives the outflow from three inland valleys-San Fernando, San Gabriel, and Upper Santa Ana. The ground-water reservoir is quite generally confined beneath impermeable material, except in the relatively small intake areas adjoining the passes from the inland valleys. Ground water is recharged in those intake areas and under natural conditions moves westward toward the ocean. However, this movement is seriously impeded along the Newport-Inglewood barrier (produced by faulting and uplift). The West Basin-extending from Long Beach to Santa Monica-lies beyond that barrier.

Pumpage from walls in the W' est Basin is currently about 90,000 acre-feet a year. The replenishment by underflow across the Newport-Inglewood barrier would be far less than this amount even under the conditions preceding development. In recent years more than 300,000 acre-feet of water has been pumped annually in the inner part of the coastal plain, and water levels there have been drawn down about in the same amount as those in the West Basin. Although replenishment across the barrier has remained nearly constant, much of the pumpage in the West Basin has been from storage, and water levels have declined until they are below sea level in most of the basin and more than 70 feet below sea level in some areas. Because of the landward gradient that has been developed, ocean water has moved as much as 2 miles inland from the coast, along a 12-mile strip that includes Manhattan Beach and Redondo Beach.

It is evident that the problem of overdraft and salt-water contamination cannot be solved within the West Basin alone, because replenishment is governed by conditions in the rest of the Coastal Plain. Complete cessation of pumpage within the IVest Basin would result in movement of sea

13 Reference: Poland, J. F., A. A. Garrett, and Allen Sinnott, "Geology, Hydrology, and Chemical Character of the Ground Waters in the Torrance-Santa Monica Area, Los Angeles County, Calif.," U.S. Geol. Survey, Duplicated rept., 1948, 472 pp. 
water as well as fresh water toward the areas of deepest water levels, and as the basin filled with this mixed water, underflow across the Newport-Inglewood barrier would diminish because of reduced hydraulic gradient.

Geologic conditions appear to be favorable, however, for artificial recharge in the sand-dune areas along part of the coast of the West Basin. It has been pointed out that such recharge would create a ground-water "mound" that would stop the advance of sea water from the coast, and thus protect the rest of the basin from intrusion. The sewage effluent from Los Angeles has been proposed as a possible source of water for this recharge. After treatment, and after percolating through the equivalent of a sand filter, these waters would likely be found to be quite safe for use when pumped from wells.

Pumping from storage in fresh ground-water rescrvoirs in a few areas has created conditions favorable for the incursion of inferior water from other aquifers. In some cases, the contaminant water has come in through wells perforated in both water-bearing formations, but in others it has evidently reached the fresh-water reservoir without such aid. Encroachment of bad water from other formations ${ }^{14}$ has been observed in the ground-water reservoir developed by El Paso, Tex. Deterionation in quality of supplies, due to lcakage through wells, has been noted along the rest slope of San Joaquin Valley (page 43) but is likely to occur there in any case as depletion of storage progresses.

El Paso, Tex. ${ }^{15}$ Two different types of water are available

14 As distinct from occurrences of brines "native" to certain formations, which are commonplace and may yield products of commercial value as in the Saginaw Valley, Mich., and at Searles Lake, Calif.

15 References: Sayre, A. N., and P. P. Livingston, Ground-water Resources of the El Paso Area, Texas, U.S. Geol. Survey Water Supply' Paper 919, 1945, $190 \mathrm{pp}$.

Scalapino, R. A., "Ground-water Resources of the El Paso Area, Texas," Texas Board of Water Engineers, Progress rept. $6,1949,22 \mathrm{pp}$. 
to El Paso-highly mineralized water in the shallow alluvium of El Paso Valley which is recharged chiefly from the Rio Grande, and the more desirable water obtained at depths greater than 500 feet in that valley as well as under the mesa to the north. Daily pumpage of this good water for El Paso and adjacent Ciudad Juárez increased progressively from 1 million gallons a day in 1906 to $25,500,000$ gallons a day in 1943. The average replenishment is estimated to be about 15 million gallons a day. As a result, water levels in the wells in the mesa well field dropped as much as 15 feet between 1936 and 1919. There has been no sustained downward trend in artesian pressures of the deep wells in El Paso Valley. However, mineral content has increased steadily since 1935 in several of these deep wells and in some wells on the mesa near the rim, probably because of percolation from the shallow alluvium in the valley.

Since 1943 the demand for water in the area has increased still further, and by 1948 more than 28 million gallons a day was being pumped. However, the pumpage from the deep valley wells and from the mesa has been reduced to 2 ? million gallons a day, thanks to the completion in 1913 of a plant capable of treating as much as 10 million gallons a day of the mineralized water of the Rio Grande and adjacent shallow walls. Experiments have shown that it is feasible to recharge the deep valley wells with treated surface water from this plant and thus reduce or halt the encroachment of salt water.

Another form of progressive deterioration in quality of ground water occurs in reservoirs that are replenished in large part from water that has already been used and has acquired soluble contaminating material. Pumpage from these reservoirs is a contributing factor to the extent that the reservoir is emptied sufficiently to induce replenishment by the contaminating water. But the basic cause of contamination is the development and use of the water before it reaches the groundwater reservoir. The Gila River Basin in Arizona is an out- 
standing example of the increasing mineralization of water with use. This problem of salinity increase is not solved by limiting the application of irrigation water to the point of no return to the ground-water reservoir, even if practical means could be developed to provide only the quantities of water required by the growing crops. All water applied for irrigation carries some mineral matter. If the water is all returned to the atmosphere by evapotranspiration, these salts are left to accumulate in the soil. Effective irrigation practices must include the removal of these salt residues from the soil by the application of water in excess of the requirements of plants.

Wellton-Mohawk Area of the Gila River Basin, Ariz. ${ }^{16}$ The Wellton-Mohawk area is a ground-water reservoir traversed by the Gila River some 20 to 50 miles above the point where it flows into the Colorado River. The pumpage from wells for irrigation increased from 35,000 acrefeet in 1945 to 45,000 in 1949, of which perhaps one-fourth returned to the ground-water reservoir by downward percolation. The rate of pumping has exceeded the replenishment from all sources for a long time, and for 20 years the water table under the irrigated areas has been lowered at an average rate of about a foot a year.

The mineral salts in the Wellton-Mohawk ground water have always been high by national standards. Water from wells near the margin of the district, probably derived from local precipitation, commonly carries about 2,000 parts per million of dissolved solids. The water pumped by irrigation wells, derived chiefly by seepage from the Gila River and by westward percolation in the alluvial materials, is considerably more mineralized, and the concentration is increasing. Twenty years ago, these waters carried as much as 7,000 parts per million of dissolved matter, compared

16 Reference: Babcock, H. M., S. C. Brown, and J. D. Hem, "Geology and Ground-water Resources of the Wellton-Mohawk Area, Yuma County, Arizona," U.S. Geol. Survey, Mimeo. rept., 1947, 22 pp. 
with waters pumped today that have as much as 16,000 parts per million. In one well the dissolved mineral content has increased 10 times since 1927. Most of the water now pumped is classified as "injurious to unsatisfactory" for irrigation. The problems of excessive mineral content are most acute in the Wellton-Mohawk area, but exist also in the Sentinel and Gila Bend areas, which are upstream along the Gila River.

CORRECTIVE MEASURES TO REDUCE OVERDRAFT. The problems of reservoir depletion are not new in the history of groundwater development. The drought years of the 1930's brought dwindling yields from wells in many areas and convinced the residents that their ground-water resources are not inexhaustible. Long before that in some regions, there was earnest consideration of the problem of dwindling resources, followed by corrective measures which have in many instances halted further depletion.

The sternest method of halting depletion of a reservoir is to reduce draft from wells without offering any substitute water supplies, a procedure which can result only in driving people out of the area. This would be nature's cure, if water is pumped from storage until a ground-water reservoir is emptied. No areas are known to have yet been affected by a mass emigration that could be attributed entirely to failing groundwater supplies, although many individual enterprises have been abandoned because the "well has gone dry."

Reduction in draft is the basis of corrective measures to halt the overdraft from the small Raymond Basin, in which Pasadena, Calif., is located. The decision reached in the case of Pasadena v. Alhambra et al., following a long battle over water rights, has resulted in an over-all reduction of about 30 per cent in the draft on the ground-water reservoir. ${ }^{17}$ However, imports from the Colorado River provide water to the Los Angeles region in quantities greater than current needs, and

17 Pasadena v. Alhambra (33 Cal. 2d 908, 207 Pac. 2d 17) 1949; certiorari denied (339 U.S. 937) 1950. 
Pasadena is already served from this source. The same alternative source may eventually be available to some residents of Tia Juana Valley at San Diego, where pumpage has been curtailed by adjudication.

Conservation practices to ensure that water be withdrawn from wells only for beneficial use have reduced ground-water draft in many areas. Several states have statutory prohibitions against waste from artesian wells, and beneficial use has been declared in many states to be the basis, the measure, and the limit of a ground-water right. Methods of eliminating waste from wells range from the simple attachment of a valve to control the flow of an artesian well, to replacing a corroded casing that permits underground leakage, or to the plugging of "wild wells" in which water from an aquifer rises uncontrolled outside the casing. The Pecos Valley Artesian Conservancy District has done much to reduce wastage of water from the Roswell artesian basin, N. Mex. The state engineer of Utah has also been actively engaged in plugging "wild" flowing wells in several ground-water reservoirs throughout the state, and the state engineer of Nevada has plugged some wells in Las Vegas Valley. The elimination of waste from wells, whether by voluntary action of the owners or by action of district and state agencies, has been shown to result in higher water levels and artesian pressures in other wells in the region. However, in many areas where ground-water draft has long exceeded the replenishment, wells have long since ceased to flow by artesian pressure, and wastage of water from wells is likely to consist chiefly of inefficient use of the water; in these areas more efficient irrigation practices are required.

In several states having ground-water laws based upon the "appropriation" doctrine (see page 246), there have been administrative determinations that there is no unappropriated water in certain ground-water reservoirs. All available water is deemed appropriated in several ground-water reservoirs having a long history of draft in excess of replenishment. In the Roswell Basin in New Mexico, in Cedar City Valley in Utah, Las Vegas Valley in Nevada, and the Eloy area of the Santa 
Cruz Valley in Arizona (see page 38), the ground water is considered to be fully appropriated, and new wells are drilled only as replacements to wells covered by established rights.

Roswell Basin, N. Mex. ${ }^{18}$ About 120,000 acres of land is irrigated in the Roswell Basin of the Pecos Valley, almost entirely from wells. The first artesian well was drilled into the limestone aquifer in 1891, and the great derelopment of large flowing wells for irrigation began about 1903. Artesian pressures dropped markedly during the next decade, and new development was practically stopped by 1915. By 1925 the area in which artesian flows could be obtained had shrunk from the original 660 to 425 square miles, and many farms in the outskirts of the valley had been abandoned.

The New Mexico ground-water law, first passed in 1927 and then modified in 1931 to meet objections of unconstitutionality of minor features, was intended primarily to protect the water resources of this basin from exhaustion, although the regulatory procedures are applicable to all ground-water reservoirs in the state. The statute gives the state engineer authority to safeguard the basin's water supplies against overdevelopment and waste. In the past two decades waste from wells has been practically eliminated, and no new water rights have been granted for additional development of the artesian basin. In recent years the withdrawal by wells from that basin has been of the order of 210,000 acre-feet a year. Partly because of control measures, but undoubtedly with considerable assistance from exceptionally heavy precipitation in 1941, the average annual artesian pressures in wells were generally higher in the

18 References: Fiedler, A. G., and S. S. Nye, Geology and Ground-water Resources of the Roswell Artesian Basin, N. Mex., U.S. Geol. Survey Water Supply Paper 639, 1933, 372 pp.

Morgan, A. M., Geology and Shallow-water Resources of the Roswell Artesian Basin, N. Mex., N. Mex. State Eng. 12th13th Bienn. Rept., pp. 155-249, 1938.

Bliss, J. H., Ground-water Problems of New Mexico, Assoc. Western State Engr. Proc. 21, pp. 55-58, 1948. 
winter of 19.12 than since 1926; they have dropped nearly 12 feet in the winters of the succeeding seven years. The water levels in artesian wells have dropped lower than ever before in the summers of 1948 and 1949.

Overlying the artesian basin is a shallow ground-water reservoir, replenished in large part by upward leakage from the artesian reservoir and by downward percolation from irrigated lands. Little water was pumped from this shallow reservoir before 1927. When further drilling of artesian wells was stopped, there was a marked acceleration in shallowwater development, and by 1937 the shallow reservoir was also closed to further permits except for replacement wells. In recent years the pumpage from shallow wells has been about 120,000 acre-feet a year. In part, this development represents salvage of water that would otherwise be discharged by evapotranspiration or by seepage into the Pecos River, and it also represents a reuse of water drawn from the artesian reservoir and applied for irrigation. But pumping from the shallow reservoir has lowered the water levels by 20 feet or more in an area of 65 square miles, and undoubtedly the upward leakage from the artesian reservoir has increased as a result.

The wise regulation of the development of the basin has been shown to require an adequate foundation of hydrologic data, in order to achieve maximum utilization of the water resources and protect the holders of established rights. Present information suggests that total draft on the combined reservoirs may still be in excess of average replenishment, but it may be possible to bring the system more nearly into balance by salvaging some of the water still being lost by natural discharge. On the other hand, some outflow to the Pecos River must be permitted to continue, both to meet the established rights to water downstream and as a means of disposal of mineral salts from the Roswell Basin. It is likely that some well owners are withdrawing water in excess of the quantity to which they are legally entitled, and the overdraft may be substantially reduced if 
stern measures are taken to prevent withdrawals except under established rights.

Cedar City Valley, Utah. ${ }^{19}$ In Cedar City Valley in southwest Utah, some wells have been pumped for irrigation for more than 25 years, but development was accelerated markedly during the early 1930's, particularly on the alluvial fan of the chief inflowing stream, Coal Creek. Water levels in wells on this fan declined sharply as a result of this increased draft during years of little recharge and by 1935 were 10 to 15 feet lower than in 1932. Utah's ground-water law was passed in 1935, following a series of drought years when not only stream supplies but recharge to ground-water reservoirs throughout the state had been far below normal. Soon thereafter the state engineer declared the ground water of the Coal Creek alluvial fan fully appropriated and has issued no permits for new irrigation wells since that time. The storage in the ground-water reservoir has increased somewhat from the minimum recorded in 1936. Water-level trends in wells correlate rather well with annual precipitation. Annual pumpage is of the order of 15,000 acre-feet.

There is some loss of ground water by evapotranspiration in the lowest parts of Cedar City Valley, chiefly derived from the alluvial fans of minor tributaries. Permits have been issued by the state engineer for several irrigation wells to develop this unappropriated water. Some of the water now lost by evapotranspiration comes from the Coal Creek fan, which is so steep that present pumping lifts would need to be doubled or trebled if ground water were to be prevented from moving to present areas of evapotranspiration. Thus the declaration that there is no unappropriated water is based in part on the economy of the region-the value of crops produced and the cost of power for pumping. The ground-water users under existing conditions cannot afford

19 Reference: Thomas, H. E., and G. H. Taylor, Geology and Ground-water Resources of Cedar City and Parowan Valleys, Utah, U.S. Geol. Survey Water Supply Paper 993, 1946, 210 pp. 
to extract all the supply perennially available, and until that is done some waste will continue by evapotranspiration.

Las Vegas Valley, Nev. ${ }^{20}$ Las Vegas Valley is officially a tributary of the Colorado River, but the water that flows from Las Vegas Wash into Lake Mead is limited to the negligible quantities that run off from the lower part of the valley after intense storms, and the valley to all intents and purposes is a closed basin. Most of the precipitation upon the drainage basin soon returns to the atmosphere by evapotranspiration; the rest percolates downward to enter the ground-water reservoir, and nowhere is there sufficient surplus to form a perennial stream. Most of the ground water comes from the high Spring Mountains west of the valley and moves eastward toward the valley floor; under natural conditions it came to the surface near the city of Las Vegas in large springs and seeps, which watered the broad meadows that caught the eye of early Spaniards and suggested the name for the valley. The springs, with a combined annual yield of about 7,000 acre-feet, furnished all the water supplies for the valley's residents until 1907.

A flowing artesian well drilled in 1907 started a boom, and by 1912 there were about 75 flowing and 25 nonflowing wells in the valley. The flow from springs decreased somewhat, but the total yield from wells and springs rose to more than 20,000 acre-feet a year. In the next 30 years the number of wells increased to more than 300 , but the total groundwater draft remained about 22,000 to 24,000 acre-feet a year. During this time artesian pressures declined markedly, especially in the vicinity of Las Vegas where wells were closely spaced, and several wells ceased flowing.

Since 1942, the population of Las Vegas Valley has more than doubled, and water requirements have increased accordingly. In part, the increased demand has been met by

20 Reference: Maxey, G. B., and C. H. Jameson, Geology and Water Resources of Las Vegas, Pahrump, and Indian Spring Valleys, Nevada, Nev. State Engr. Water Res. Bull. 5, 1948, 121 pp. 
conservation measures resulting from an educational program started by the Nevada state engineer in 1945. In 1947, it was estimated that wastage had been reduced to less than 15 per cent of the discharge from wells and springs, mostly through voluntary cooperation of the well owners, although the state on two occasions sealed "wild" wells and charged the cost to the well owner. Even so, by 1948 the total ground-water draft had risen to 34,700 acre-feet, and in the following summer the city of Las Vegas placed restrictions on lawn sprinkling. Also in 1949, the state engineer prohibited the drilling of any new irrigation wells in a 42 square-mile area including Las Vegas and about 90 per cent of the area of ground-water development. Municipal and domestic wells may still be drilled within this area, however. This regulation is designed to prevent any major increase in draft within the area of concentrated derelopment. The development of the entire artesian basin is considered to be approaching the limit set by natural replenishment, and drilling of additional irrigation wells is discouraged throughout the valley but not yet strictly prohibited.

In Las Vegas Valley there is a shallow ground-water reservoir, as in the Roswell Basin, which receives water by upward leakage from the artesian reservoir and, in the vicinity of Las Vegas, waste water from irrigation, cooling, and sewerage. About 8,000 acre-feet of water is discharged annually from the shallow reservoir by evapotranspiration in an area of about 5,000 acres where the water is within 10 feet of the surface. This shallow water thus constitutes a potential source of additional water, provided that the requirements are not large. However, for large additional supplies, Las Vegas Valley looks to the Colorado River, which has supplied as much as 23,000 acre-feet during war years to the industrial area around the town of Henderson in the southeast part of the valley but which now supplies only about 5,000 acre-feet annually. The withdrawal from the Colorado River by the state of Nevada is limited by compact to 300,000 acre-feet a year. The state is already 
diverting part of its share to other valleys, and the ultimate quantity available for Las Vegas Valley may be about 200,000 acre-feet.

For many ground-water reservoirs, it has been possible to reduce the disparity between draft and natural replenishment by increasing the replenishment artificially, which is a more desirable solution to the problem than the alternative of restricting or reducing the withdrawal of ground water. Several of California's coastal valleys are traversed by streams responsible for much of the ground-water replenishment but which also discharge considerable quantities of water into the ocean. Since 1934, the Santa Clara Valley Conservation District has constructed storage dams and percolating works to divert surplus stream water into the ground-water reservoir of Santa Clara Valley (page 53). Similarly, spreading basins along the Santa Clara River in southern California have put nearly 10,000 acre-feet of water underground for the Oxnard Plain, thus reducing the overdraft. The Los Angeles County Flood Control District has constructed diversion works and spreading grounds for artificial recharge of gromnd-water reservoirs from water held back by the flood-control dams constructed by the Corps of Engineers and by the Los Angeles County Flood Control District. And comprehensive plans have been completed for utilization of surplus flows of the Salinas River to relieve present conditions of overdraft and salt-water encroachment in the ground-water reservoir of Salinas Valley. It may be feasible to use winter stream surpluses to relieve overdraft in several other California valleys, including Livermore Valley, Santa Maria Valley, and the Santa Ynez Valley.

The effluent from sewage-treatment plants has been utilized by several western cities for irrigation, and some reclaimed water is returned by percolation to ground-ivater reservoirs. In Denver, Colorado, about two-thirds of the water used for municipal supply eventually reaches the sewage-treatment plant; the effluent is discharged to the South Platte River, 
where it is reused for irrigation. ${ }^{21}$ It has been proposed that the sewage effluent from Los Angeles be used for artificial recharge along the coastal sand dunes south of Santa Monica to offset overdraft and halt saline-water encroachment in the west basin of the Los Angeles Coastal Plain. Consideration is being given also to the possibility of reusing for irrigation the sewage effluent which now goes into San Francisco Bay.

Another attractive solution to problems of deficient water supplies is the importation from regions of surplus. Such importations may be expensive, especially when they involve facilities to carry water a hundred miles or more, but many communities have been well justified in the expense and are fortunate to have had the vision to divert these surpluses to their use while the water was still unappropriated. The habitable places in the arid W'est are generally not self-sufficient in precipitation and are thus dependent upon a sort of "import" via streams from the more humid but less habitable mountainous regions. Here we are concerned, however, with imports from beyond the watershed in which the community is situated.

The larger metropolitan areas in California are all dependent to some extent upon such imports. San Francisco and Oakland derive their water supplies from pipelines extending, respectively, to reservoirs on the Tuolumne and Mokelumne Rivers in the Sierra Nevada. The small ground-water reservoirs bordering San Francisco Bay have been pumped so heavily that salt water has moved landward as much as 5 miles in some areas. As affected wells have been abandoned, the imported water has been substituted in many cases for domestic supplies.

Los Angeles has been the outstanding importer of water in the West for many years. In 1913, when its population was less than 200,000, the city spent 25 million dollars for the Owens Valley aqueduct, and since Hoover Dam was constructed, it has underwritten bonds for 200 million dollars for the Colo-

21 Hutchins, Wells A., Sewage Irrigation as Practiced in the Western States, U.S. Dept. Agr. Tech. Bull. 675, 1939, 59 pp. 
rado River aqueduct. With these importations, plus available local supplies, the metropolitan district now serves $3,500,000$ people and has reserves sufficient for an estimated 8 million population. San Diego also imports Colorado River water to supplement its local supplies of surface and ground water. In addition, the Colorado River furnishes the water for the hot desert valley in southeastern California which is occupied by the Salton Sea. The Imperial Valley, south of Salton Sea, contributes many fresh vegetables and fruits to the nation's market basket in the winter; it is underlain by river sediments too fine to form an acceptable ground-water reservoir, and the water for irrigation of more than 400,000 acres has been diverted from the Colorado River since 1907 (page 199). Coachella Valley, north of the Salton Sea and the major producer of domestic dates, has been dependent upon an artesian ground-iwater reservoir for its irrigation supplies. In the past 50 years, development has increased until most wells have ceased flowing, and even with a high degree of conservation, there has been a gradual depletion of storage in the ground-water reservoir. Water imported from the Colorado River through the Coachella branch of the All-American Canal is expected to relieve present conditions of overdraft on that ground-water reservoir.

The city of Santa Barbara has depended for its water supply upon transmountain diversion from the small Gibraltar reservoir on the Santa Ynez River. This supply has been inadequate for years, and, since 1948, ground water has been pumped increasingly from the reservoir under the city. The ground-water reservoirs in the contiguous Goleta and Carpinterin Valleys have been overpumped in recent years, and water levels have dropped below sea level, but Goleta Valley is protected from saline intrusion by a fault barrier along the coast. The water shortage in all three valleys will be relieved by diversion from the Cachuma reservoir now under construction, which will store up to 210,000 acre-feet of flood waters of the Santa Ynez River.

The most magnificent project yet undertaken for transfer- 
ring water from areas of surplus to areas of water deficiency is the Central Valley of California Project of the Bureau of Reclamation. This project, originating as the state Water Plan by the state engineer of California, includes transfer of several million acre-feet annually from the Sacramento Valley to the San Joaquin Valley. The "Central Arizona" plan for importation from the Colorado River to overcome water deficiencies in the Gila River Basin is of similar stupendous proportions. The plan is being considered by Congress, but many years can be expected to elapse before the delivery of the first water, if the controversy between Arizona and California as to Colorado River water rights must first be settled. In any case, the diversion must await the regulation of the Colorado River flow by dams not yet constructed above Hoover Dam.

San Joaquin Valley, Calif. ${ }^{22}$ San Joaquin Valley (the southern two-thirds of California's "Central Valley") is by far the greatest user of ground water in the United States. It is estimated that about 7 million acre-feet of water is pumped annually from some 40,000 irrigation wellsnearly a quarter of all the water that is produced by wells throughout the nation.

The long-term average stream flow into San Joaquin Valley (from the Mokelumne River south) is of the order of 11 million acre-feet. With the aid of several reservoirs, most of this surface water is utilized for irrigation by gravity diversion, and the outflow through the San Joaquin River at the

22 References: Trauger, F. D., "Description of an Early Experiment in Ground-water Recharge through Wells at Lindsay, California," Unpublished rept., 1949, $10 \mathrm{pp}$.

Muckel, D. C., "Report to Cooperators on Water-spreading Investigations in San Joaquin Valley, California," U.S. Soil Cons. Service rept., pp. 4-16, April 1919.

"Comprehensive Plan for Water Resources Development, Central Valley Basin, Calif.," U.S. Bur. Recl. Project Planning Rept. 2-4, 0-3, p. 229, November 1945.

Stoner, D. S., "Groundwater Investigations in the Central Valley," U.S. Bur. Recl. Region 2, Mimeo. rept., July 1950, 172 pp. and 34 plates. 
lower end of the valley is made up largely of return flow from irrigation. A substantial part, perhaps half, of the water that enters the valley in streams serves to recharge the ground-water reservoir, either by seepage from stream channels and irrigation canals or by percolation from irrigated lands. The pumping draft throughout the valley is believed to exceed average ground-water replenishment by about 1,500,000 acre-feet, and for many years there has been a progressive depletion in ground-water storage. Water deficiencies-in precipitation, stream flow, and groundwater replenishment-are generally greatest near the south end of the valley and become progressively less toward the north.

This short statement of the over-all conditions in San Joaquin Valley indicates the basis for a fundamental part of the Central Valley Project: importation of water from Sacramento Valley, which constitutes the northern part of the Central Valley and annually discharges sizable surpluses into San Francisco Bay. Present plans call for ultimate construction of 38 reservoirs with capacity of 30 million acrefeet, approximately equivalent to the annual flow of all streams in the Central Valley; major canals to transport water southward; and extensive utilization of ground-water reservoirs for annual and cyclic storage. The conditions of infiltration, storage, movement, and discharge of ground water are so diverse in various parts of San Joaquin Valley that detailed hydrologic knowledge is prerequisite to maximum utilization of the imported water. Basic data are now being obtained and analyzed but in some instances not soon enough to influence the design and construction stages of the project.

In several places in San Joaquin Valley there are problems of excessive overdraft from pumping. For example, in the Delano-Earlimart area static water levels in some wells are as much as 250 feet lower than in 1905, and the pumping lifts in many wells are between 300 and 400 feet. In the Arvin-Edison area, average water levels dropped at a rate 
of about 3 feet per year between 1921 and 1938, and more than 5 feet per year subsequently; the net lowering in the area of heaviest pumping has been more than 150 feet since 1926. In the Lindsay area the mean depth to water in wells increased from 55 feet in 1921 to 135 feet in 1945, and to more than 150 feet in recent years; wells near the center of the cone of depression are pumping water of increasing salinity.

Development in other places has resulted in raising the water table, which in some areas has resulted in alkali accumulation and abandonment of farms and in others has been solved by drainage (page 197). And some areas in the lower parts of the Tulare Lake basin are afflicted with more complex problems: pumpage from deep artesian wells is depleting the ground-water storage, and the irrigated land above has such poor drainage that the water table is uncomfortably high.

The success of the Central Valley Project will be dependent partly upon utilization of the ground-water reservoir of San Joaquin Valley for storage of imported waters. These waters would perform a double duty if cropped lands could be irrigated excessively, with resulting percolation to the ground-water reservoir. The prevailing fine-textured soils of the valley interpose one difficulty here, because of the low natural rates of percolation. The percolation through tight soils has been increased substantially by application of cotton-gin trash; research is continuing to determine the specific chemical or biological property of the trash that causes increased infiltration, in the hope that synthetic manufacture and widespread application may be possible. But in many places the aquifers are at depths of several hundred feet; getting water through the surficial zone is only the first step in recharging those aquifers.

There is a further problem of replenishing the water in artesian aquifers that are important sources of the water pumped from wells. Flowing wells could once be obtained 
in about 40 per cent of the valley area, and the water in these aquifers is probably confined under impermeable materials in a sizable but unmapped additional area. These aquifers are not replenished naturally by downward percolation in the areas where the confining layer is present, but receive inflow from recharge areas that may be many miles away. Some difficulties are encountered in trying to abide by nature's method of replenishment. It is probable that the bulk of all recharge, including that to the artesian aquifers under the floor of the valley, comes from the alluvial fans of the tributary streams. The water in these permeable materials is readily replenished from the streams and from gravity diversions and irrigation. The problems of greatest overdraft are in the areas between the major tributaries and beyond the coarse deposits of their fans; they are probably due in part to the slow rates of underground movement from the stream to the area where the water is pumped.

In order to achieve effective ground-water storage of the imported water, it may be necessary to develop techniques that will by-pass the natural paths of slow replenishment and recharge the reservoir directly in the area of use. This was the basis of a successful experiment in artificial recharge through wells in the Lindsay-Strathmore Irrigation District in the first four months of 1932. The district is 10 to 18 miles south of the Kaweah River, and water has been pumped at rates that have lowered the water levels 2 to 5 feet per year. The district also uses water from 40 wells along the watercourse of the Kaweah River, where the alluvium is readily recharged during flood flows. Prior to the 1932 irrigation season, water from the watercourse was pumped into the district's flume, screened, chlorinated, and introduced into 75 per cent of the irrigation wells within the district. The wells absorbed water generally in proportion to their yield when pumped, and water levels in the reservoir rose as much as 50 feet in some places. No cases of 
well failure or damage were reported as a result of the recharge operations. The recharge was discontinued, however, because of the objections raised by other users of water in the Kaweah watercourse.

The scope of the unsolved ground-water problems in San Joaquin Valley was recognized in the comprehensive plan submitted by the Bureau of Reclamation in 1945:

If the State Water Plan and the works now under construction by the Bureau of Reclamation in the southernmost part of the Central Valley are to be fully effective as planned: (1) artificial infiltration must be accomplished in an over-all average rate sufficient that surplus water can be conveyed to underground storage whenever available; (2) water must be held in artificial underground storage in the extremely large aggregate volume necessary for full equalization of irrigation requirements over an indefinite term of years-for the area south of the Chowchilla River this volume seemingly would be as great as 16 million acre-feet; (3) water must be held in long-term underground storage in this great volume without extensive damage to lands by water-logging; (4) substantially all this water artificially stored must be salvaged by pumping from wells. However, the factual geologic and hydrologic information now available gives no assurance that these fundamental requirements can be accomplished for all parts of the area.

For the past decade the ground-water investigations in San Joaquin Valley have been spearheaded by the U.S. Bureau of Reclamation rather than by the state and Federal research agencies which have long been active in other areas of California and in other states. Thus the studies can be directed especially toward the critical ground-water questions raised by the Central Valley Project, and in part must necessarily be directed toward answering the local opposition to certain phases of that project. However a great volume of basic data of general public value is also being collected. Little of this material is published, although the results of many studies are being reported in mimeographed or limited editions. A general summary of the investiga- 
tions, released in July, 1950, shows the magnitude and complexity of the hydrologic problems in the valley.

Gila River Basin, Ariz. ${ }^{23}$ The Gila River Basin includes about half the area of Arizona and more than 90 per cent of the population, industry, and irrigated land. The basin includes several individual ground-water reservoirs, of which Safford Valley, Santa Cruz Valley, and the WelltonMohawk area are described separately. The problems of these areas-evapotranspiration losses and surface-ivaterground-water relationships in Safford Valley, heavy pumping and depletion of underground storage in Santa Cruz Valley, and increasing salinity in the Wellton-Mohawk area -are encountered also in other parts of the basin. In the basin as a whole, more than 3 million acre-feet is pumped annually from wells, and in several places water levels have declined more than 30 feet in the past decade. Hydrologic data are not complete enough to warrant estimates of the average annual replenishment or even of the amount of pumped water that returns to the ground-water reservoir.

In some localities there has been a tremendous increase in pumpage in the past decade. Deer Valley, north of Glendale, is typical. Between 1940 and 1948, eighty large wells were drilled to irrigate more than 21,000 acres, and annual pumpage increased from 600 to 88,000 acre-feet. In the eight years water levels declined an average of more than 70 feet throughout the irrigated area and more than 20 feet in a single year (1948). The average pumping lift in 1948 was about 270 feet.

Evapotranspiration losses are large in the hot deserts of the Gila River Basin. Probably more than 500,000 acre-feet

23 References: McDonald, H. R., H. N. Wolcott, and J. D. Hem, "Geology and Ground-water Resources of the Salt River Valley Area, Maricopa and Pinal Counties, Arizona," U.S. Geol. Survey, Mimeo rept., February 1947, 45 pp.

Bluhm, F. I., and H. N. Wolcott, "Ground-water Resources of Deer Valley, Maricopa County, Arizona," U.S. Geol. Survey, Mimeo. rept., October 1949, 23 pp. 
is discharged each year from ground-water reservoirs by nonbeneficial vegetation, mostly salt cedar, along the Gila River below Coolidge Reservoir, the Salt River below Phoenix, the Verde below Bartlett Dam, and the San Pedro River. In addition, there are large losses by evaporation from surface reservoirs on the Verde, Salt, and Gila Rivers.

The outflow from the Gila Basin has been reduced to a trickle by the greatly increased utilization of water within the basin. In recent years there has been no surface outflow except for a few days following heavy storms in the lower part of the basin, and the underflow down the Gila channel is considered to be only a few hundred acre-feet a year. The inevitable result of this cessation of outflow has been the accumulation of salts in the lower part of the basin-an accumulation which has become noticeable in ground waters near the Gila River channel for more than 150 miles from the mouth. The use and reuse of water for irrigation has contributed much of this salt to the lower valley by dissolving soluble materials in the soil zone. But much of the salt originates in saline springs within the basin or from rocks such as the "salt banks" along the Salt River near Chrysotile. For instance, the Clifton Springs contribute about 4 acre-feet of water and 60 tons of salt daily to the San Francisco River. Diluted by the Gila River, that water becomes entirely suitable for irrigation, and the salt spring thus gives a small advantage in quantity of water available in Safford Valley. As the salt reaches the lower part of the basin, though, it is a great detriment: each day's increment of 60 tons is enough to make 40 acre-feet of fresh water unusable for irrigation.

The proposed Central Arizona Project involves the importation of 1,200,000 acre-feet annually from the Colorado River, a quantity considered to be sufficient to replace the current overdraft on the ground-water reservoirs and to permit the flushing of excess salt from the basin. Until this water is available, the Gila Basin faces prospects of increasing difficulties, some of which may be alleviated, however, 
by salvaging water now wasted by evaporation and transpiration and by taking measures to reduce the salt inflow to the basin water supply.

\section{RESERVOIRS WITH NATURAL REPLENISHMENT}

ADEQUATE FOR PRESENT USES

In many ground-water reservoirs of the arid regions the average annual recharge is adequate for present uses. Indeed the number of such reservoirs is far greater, and their total areal extent is larger than the reservoirs in which current draft from wells now exceeds the estimated average rate of replenishment.

The natural setting for all basins in the arid regions is similar in that neither the seasonal nor annual precipitation is sufficient to meet the requirements of agriculture, or of industry or conmunities because their requirements per unit of area are ordinarily at least as great as those for farming. Communities in these regions must depend upon the limited surpluses of water from mountainous areas of more humid climate. It is inevitable that the density of population throughout the West must continue to be less than in the humid East. The regions where surface and ground-water supplies are still adequate differ from the "overdeveloped" areas chiefly in the degree of present development and use of water. They, too, can reach a "critical" point at some stage of increased development, because there just is not enough water to meet demands comparable to those met in regions of abundant rainfall.

The ground-water reservoirs here considered as having adequate replenishment are by no means devoid of groundwater problems. As the number of producing wells has increased, there has inevitably been a lowering of water table or artesian pressure in many areas, with resulting decline or cessation of yield from flowing wells, and increased cost of obtaining water by pumping. Some closely spaced wells have interfered with each other, and the yield from each has dropped off. Climatic cycles have caused concern in several areas because the subnormal replenishment in a series of dry 
years has caused declining water tables and artesian pressures and suggested the possibility of overdevelopment. State regulating agencies have prohibited further development of some ground-water reservoirs because of evidence over periods of several years of declining artesian pressures. But the groundwater reservoirs in this group have one characteristic in common, which is good evidence that recharge is at least as great as present draft: all are still losing substantial quantities by natural discharge either to streams or to areas of evapotranspiration. If there were sufficient knowledge about the natural movement of water underground, it might be possible to intercept some of that water and divert it to beneficial use without infringing on established water rights.

A few ground-water reservoirs discharge into fresh-water lakes, of which Utah Lake is an example. The ground-rvater reservoir of Utah Valley extends under the lake and provides a substantial part of the inflow to the lake. In most of the intermontane valleys of the W'est, ground water is discharged by evapotranspiration, especially from moist playas or salt flats, and from water-loving vegetation such as salt grass, greaswood, mesquite, salt cedar, willows, cottonwoods, and tules. Willcox Basin in Arizona and Toocle Valley in Utah are examples.

Utah Valley, Utah. ${ }^{24}$ Utah Valley, 25 to 75 miles south of Salt Lake City, is fortunately situated where it can harvest the water crop of tributary basins that drain parts of the high and humid Wasatch and Uinta Ranges. So productive are these drainage basins that the valley is exceptionally well provided with water, and a surplus accumulates in Utah Lake which is entirely appropriated for use in Jordan Valley to the north. There has been practically no unused outflow from Utah Lake to Great Salt Lake since 1925.

The use of ground water in Utah Valley is of the order

24 Reference: Hunt, C. B., H. E. Thomas, and Helen Varnes, "The Bonneville Basin, Part I, Northern Utah Valley," U.S. Geol. Survey rept., in preparation. 
of 50,000 acre-feet a year, chiefly from flowing wells, although there are also a few pumped wells and several springs. The use of surface water is considerably greater and is approximately at the upper limit of permissible development. Court decrees set the limits of use of water from the tributaries, and the associated canal companies that use water from Utah Lake lay claim to all water not used, as well as to the return flow from users of the water in the tributaries.

Yet, although the surface water is generally regarded as fully appropriated, and many believe that the ground water should be similarly classified, there are large quantities of water that leave the Utah Lake drainage basin unused. The computed evaporation from the lake surface in nearly every year is greater than the quantity taken from Utah Lake for beneficial use. In 31 years (1916 to 1946 inclusive) the average annual evaporation was estimated to be about 315,000 acre-feet, compared with pumped and gravity diversions averaging 245,000 acre-feet a year. The evaporation from land areas and transpiration by native vegetation have not even been estimated, but it is certain that the total in Utah Valley represents an additional natural loss of many thousand acre-feet each year.

The excessive natural losses of water in Utah Valley, and particularly from Utah Lake, have long been recognized, and several methods have been proposed for reducing them. Some suggestions involve the concentration of Utah Lake storage in a smaller area by diking off the shallower parts of the lake. Storage in deep and narrow canyon reservoirs, particularly in headwater areas, would be subject to less evaporation loss than Utah Lake storage, but good additional reservoir sites are rare, and storage of anything like the volume in Utah Lake could be achieved only at great cost.

As another alternative, it is quite possible that the ground-water reservoir could be used to advantage in providing additional water for beneficial uses. If the artesian 
pressure were sufficiently reduced by pumping from wells, some of the water now lost by evapotranspiration in the lower part of Utah Valley might be diverted instead to beneficial use. And if water were pumped from the coarser gravels of the valley, it is likely that it would be replaced by seepage from the streams, with the result that water would be stored underground, with minimum evaporation losses, rather than in Utah Lake. If the ground-water reservoir were so utilized, additional water salvaged from natural losses could be obtained only at considerable cost, because of the pumping required. Indeed, any method of increasing the utilization of water will entail large expenditures. Nevertheless, the projects that will reduce evapotranspiration losses offer perhaps the only method of obtaining substantial additional quantities of water from the drainage basin for beneficial use, because these natural losses constitute most, if not all, of the water still unappropriated.

It has been demonstrated that an industry with large requirements for water can be established in Utah Valley without infringing upon the rights of other water users. The Geneva Steel Company in its operations pumps water at the rate of 370 cubic feet per second $(210$ million gallons per day), which is about 80 per cent of the long-term average flow of the Provo River. The net consumptive use within the plant, however, is only 10 to 12 cubic feet per second.

The water rights for the steel plant, coming late as it did in the development of the valley, were necessarily acquired on a catch-as-catch-can basis. The Defense Plant Corporation had the advantages of excellent cooperation from holders of prior rights, and a temporary lease on water from Deer Creek Reservoir pending its completion by the Bureau of Reclamation and delivery to the ultimate users. Purchase of the plant property brought rights to 128 wells with a claimed combined flow of 4,400 gallons per minute throughout the year, plus rights in the irrigation season to the flow of several springs and drains yielding about 2,500 gallons per minute on the average. These basic rights are sufficient 
to furnish the water for consumptive use in present operations. All 128 wells were plugged and sealed, and a dozen wells of large capacity were drilled near the center of the property. The new wells yielded 3,000 to 5,400 acre-feet annually between 1944 and 1948, somewhat more than the annual yield of the 128 wells in 1938 to 1940 , as computed by the state engineer (2,900 to 3,400 acre-feet a year). This greater yield, however, has caused no observable loss in pressure head in private wells adjacent to the steel mill, for artesian pressures in the vicinity have fluctuated in response to precipitation and runoff in the same degree as other wells in Utah Valley. The steel mill wells, because they are remote from the plant boundaries, cause less interference in many outlying wells than was created by individual wells that formerly discharged within the plant area.

The steel plant's vast requirements for circulating (nonconsumptive) water are met by diversions from the Provo River under a contract which obligates the company to return to Utah Lake a quantity of water equivalent to the water diverted from the river, plus the nonirrigation flow of springs and drains and plus all water developed within the plant by subsurface drains. Records show that the lake now receives quantities of water from the plant area substantially greater than were contributed prior to construction of the mills, and greater than the amount of water diverted from the river for plant use. The excess may be due in part to climatic conditions, because recent years have been somewhat wetter than the prewar years, and a greater flow from the area to the lake would be expected. But certainly, a substantial part of the excess represents water salvaged by the company from loss by evapotranspiration within the steel-plant area.

The quantity developed by the subsurface drains (constructed to lower the shallow water table in the plant area) is two to five times as great as the total return flow from the area in prewar years. In 1948 the Geneva Steel Company released 3,300 acre-feet more water to the lake than required 
to meet all its obligations for diverted surface water, nonirrigation-season spring flow, and developed subsurface water. This surplus represented more than half the water yielded by the company's wells.

It must be concluded, therefore, that the Geneva Steel Company, even with its enormous use of water, does not deplete the net available supplies as much as did the same property under an agricultural economy. And the best prospect for development of additional water supplies in the valley lies in the possibility of similarly salvaging water now lost by natural processes. Such development requires an adequate knowledge of the hydrology, intelligent planning, and wise management of the supply and its uses.

Willcox Basin, Ariz. ${ }^{25}$ The Willcox Basin is a closed basin in southeastern Arizona. Water has been pumped from wells for irrigation for 40 years, but the pumpage has been increasing rapidly in recent years-from about 15,000 acrefeet in 1946 to 28,000 in 1949. The water table has dropped as much as 25 feet below its original position in some pumped areas, grading to a fraction of a foot near the outer limits of the basin.

The Willcox Playa in the lowest part of the closed basin discharges ground water by evapotranspiration at a rate estimated to be of the order of 75,000 acre-feet a year. It is not known how much of this waste could be economically salvaged and converted to beneficial use.

Tooele Valley, Utah. ${ }^{26}$ Tooele Valley, about 30 miles southwest of Salt Lake City, is bordered on the east and west by mountains that rise as much as 5,000 feet above the valley floor. Four small perennial streams draining these ranges 25 Reference: Jones, R. S., and R. L. Cushman, "Geology and Ground-water Resources of the Willcox Basin, Cochise and Graham Counties, Arizona," U.S. Geol. Survey, Mimeo. rept., May 1947, 35 pp.

26 Reference: Thomas, H. E., Ground Water in Tooele Valley, Utah, Utah State Engineer, 25th Biennial Rcpt., pp. 97-238, 1916. 
are the principal sources of municipal and irrigation water used in the valley. There are also about 1,100 wells in the lower part of the valley, most of them flowing and some large enough to be used for irrigation. The wells yicld about 7,000 acre-feet a year, and an additional 10,000 acre-feet is piped from springs to the American Smelting and Refining Company's smelter at Garfield, for industrial use. Smaller springs along the margins of the valley discharge about 5,000 acre-feet a year, most of which is not used. In addition, ground water is discharged by evapotranspiration in an extensive area in the northern part of the valley where it borders Great Salt Lake.

The average annual replenishment to the ground-water reservoir is estimated to be more than twice the amount currently put to beneficial use. Recharge is principally from water in canyons draining the mountain ranges, with a small contribution from precipitation within the valley. The recharge has been increased, at least temporarily, by water flowing from the Elton tunnel, completed in 1941 into the Bingham mining district, and has resulted in some increase in flow from wells in the small Erda irrigation district. The quantity of replenishment correlates closely with regional precipitation, and since the drought of 1931 to 1935 there have been appreciable increases of storage in the groundwater reservoir.

It has been estimated on the basis of detailed studies in a few of these valleys and reconnaissance in several others that water-loving vegetation in the arid regions may waste as much as 25 million acre-feet of ground water, which is almost twice the average annual flow of the Colorado River into Lake Mead. ${ }^{27}$ In the Great Basin, which includes nearly all Nevada and extends into Utah, Idaho, Oregon, and California, not a drop of water can flow to the oceans, and all precipitation ultimately returns to the atmosphere; in this basin more than a

27 Robinson, T. W., "Determination of Consumptive Use of Water by Native Vegetation," Nevada State Engineer's Third Water Conference, 1949. 
hundred ground-water reservoirs have been listed, and in only three of those is the draft from wells considered to be close to the average natural replenishment. In several others perhaps half to two-thirds of the available water resources are now being utilized, but most of these ground-water reservoirs are still practically undeveloped. Nevada has a number of undeveloped valleys of varying potentialities, and the state engineer in cooperation with the Federal Geological Survey and Soil Conservation Service has a comprehensive program under way to delineate the areas where ample water resources and suitable lands are available for development.

Perennial streams drain several of the valleys in which there is substantial draft on ground water by native regetation. The Safford Valley along the Gila River in Arizona is noteworthy because of the heary losses by evapotranspiration, but most ground-water reservoirs along major streams furnish water for substantial evapotranspiration, as well as for some of the stream flow. Attempts to recover and utilize the water now lost to native vegetation may cause a depletion in stream flow and thus infringe upon the rights of downstream users, even though there is an increase in the total water put to beneficial use. Maximum utilization of water resources in these places requires fairly complete knowledge of the relationship between ground water and surface water. These problems are discussed further in the section on Watercourses.

Safford Valley of Gila River Basin, Ariz.." Water was diverted from the Gila River for irrigation in Safford Valley as early as 1872. Land irrigated from the river, based on diversion rights of 1 sccond-foot for each 80 acres, increased to 16,000 acres by 1890 and to 32,500 acres by 1920 , after which no further diversion rights were granted. Pumping

28 References: Gatewood, J. S., et al., Use of Water by Bottom-land Vegetation in Lower Safford Valley, Arizona, U.S. Geol. Survey Water Supply Paper 1103, 1950, $210 \mathrm{pp}$.

Turner, S. F., et al., "Ground-water Resources and Problems of the Safford Basin, Arizona," U.S. Geol. Survey, Mimeo. rept., December 1946, 28 pp. 
from wells for irrigation began in 1930, chiefly to supplement the surface water in years of low flow; surface water has been preferred when available because of the deleterious effect upon the irrigated lands of sodium in the ground water in parts of the valley. The pumpage from wells varies from year to year depending upon the amount of water available from the stream: in 1948, when 75,000 acre-feet was diverted into canals, 110,000 was pumped from wells; in 1949, the river furnished about 168,000 acre-feet, and pumpage dropped to about 40,000 .

The ground-water reservoir of Safford Valley is part of a watercourse in which both surface water and ground water are moving toward Coolidge Reservoir. By pumping, it has been possible to obtain almost as much water for irrigation in the valley during dry years as in normal years, but since this pumpage necessarily depletes the outflow from the valley, the water shortages during droughts are enhanced for downstream users. Many of the water rights in Safford Valley antedate those for downstream use, and particularly those which are dependent upon storage in Coolidge Reservoir, constructed in 1928. On the other hand, part of the water in Coolidge Reservoir is used on Indian lands having rights recognized as antecedent to those in Safford Valley.

The bottom land of the Gila River is covered by a rank growth of vegetation. In a 46-mile reach of the river (35 air-line miles) in lower Safford Valley, there is about 9,300 acres of salt cedar, baccharis, cottonwood, and mesquite, all users of large quantities of ground water. Detailed studies in 1944 showed that the vegetation in the lower two-thirds of the valley wasted 28,000 acre-feet of water, of which 23,000 was from the ground-water reservoir. The total waste in the valley was about 50,000 acre-feet in 1944. About 75 per cent was transpired by salt cedar, an import from the Mediterranean region which is rapidly supplanting the native water-loving plants in the Southwest, using more water than any of them.

In addition to wasting valuable water, these plants in- 
crease the hazard of floods by reducing channel capacities and increase the concentration of mineral salts in the soil, at least temporarily. There is no question that this waste should be stopped, either by clearing the vegetation or by getting the water out of reach, but practical and efficient methods have not yet been worked out. The salt cedar in particular is prolific and is not easily eradicated. In some areas it is possible to eradicate water-loving vegetation by pumping until the water table is lowered beyond the reach of the roots. In Safford Valley such pumping would deplete the flow of the river, and if the water table could be depressed sufficiently to reduce evapotranspiration in the bottom lands, much of the water for Coolidge Reservoir might eventually have to come from wells rather than from stream flow.

Another evidence of surplus ground water in many arid valleys is the waterlogging of lands once suitable for cultivation. This problem of rising water table has been solved in many areas, especially in California and Arizona, by pumping, and more generally by drainage canals. But there are thousands of acres of waterlogged land in Helena V'alley and other valleys in Montana, in San Luis Valley in Colorado, and in other irrigated valleys. Generally the high water table has developed as a result of irrigation and thus is a problem related to man's use of land and surface water, discussed in the following chapter.

Helena Valley, Mont. ${ }^{29}$ The agricultural lands of Helena Valley are largely dependent upon gravity diversions from streams for irrigation, as in many other high mountain valleys of Montana. Lands in the lowest part of the valley were the first to be irrigated. As lands higher on the slopes were

29 Reference: Lorenz, H. W., F. A. Swenson, and H. A. Swenson, Geology and Ground-water Resources of the Helena Valley, Montana, U.S. Geol. Survey Circ. 83, in press. 
brought under irrigation, many of these bottom lands have been afflicted by rising water table. Currently about 8,000 acres in Helena Valley is waterlogged. It has been proposed that a 3-mile tunnel be constructed from the Canyon Ferry Dam to divert into Helena Valley enough water to irrigate 10,000 acres of new land and to supplement the water supply to another 15,000 acres of land, chiefly on the upper slopes of the valley. This proposed diversion may well increase the waterlogged areas in the lower part of the valley.

Helena Valley's ground-water reservoir is tapped by a few irrigation wells, and it is capable of producing much larger quantities than now developed. There is a good possibility that pumping from wells for irrigation of the lower part of the valley would lower the water table in waterlogged areas and also relcase surface-water supplies for use on lands higher on the slopes.

San Luis Valley, Colo. ${ }^{30}$ San Luis Valley in the Upper Rio Grande basin has a valley foor generally more than 7,000 feet above sea level. Irrigation is accomplished mainly by diversions from the Rio Grande and other streams tributary to the valley but is supplemented to considerable extent by water from approximately 5,000 flowing wells and 2,000 pumped irrigation wells of large capacity. Since irrigation began about 1874, the ground-water storage in the valley has increased; the area of artesian flow has expanded, and some shallow gravels have been saturated and subsequently tapped by wells for supplemental irrigation. Farmers have found the coarse, permeable soils to be ideal for subirrigation along the west slope, where it is possible to maintain

so References: Robinson, T. W., and H. A. Waite, "Ground Water in the San Luis Valley, Colorado," U.S. Geol. Survey (Contribution to the Rio Grande Joint Investigation), 1937, $119 \mathrm{pp}$.

"Water Facts in Relation to a National Water-resources Policy," U.S. Geol. Survey, Mimeo. rept., Appendix C, pp. 24-26, April 1950. 
the water table under a crop at any desired depth merely by adjusting the gates and checkdams along the surrounding ditches.

The Rio Grande has piled alluvium along its course and thus created a closed basin in the north half of the valley. Surplus irrigation water moves toward the sump area of this closed basin and accumulates in numerous small lakes. There has been a progressive accumulation of salts in the low areas, and, as the water table has risen, some valuable lands have become waterlogged. A project to drain the closed basin by means of a canal to the Rio Grande is now being studied and may ultimately result in reclaiming some of the land and in making more water available for beneficial use downstream, and if transfer arrangements can be worked out, to the upper reaches of the San Luis Valley.

In several ground-water reservoirs of the West where the annual replenishment is in excess of the present ground-water draft, the surplus is discharged into streams. In Willamette Valley, Ore., for example, only a very small proportion of the annual replenishment to the ground-ivater reservoir is used by wells, and the remainder is discharged to streams chiefly during the dry part of the year. The ground-water reservoir under the Snake River Plain in Idaho discharges some of its surplus into the Snake River at the famed large springs along the north wall of the canyon. Ground-water reservoirs in many of the higher mountain valleys likewise discharge surpluses into streams; indeed, these areas are generally located where the climate is sufficiently humid during some part of the year so that the hydrologic conditions approach those of the humid East.

Willamette Valley, Ore. ${ }^{31}$ The three largest cities and two-thirds of the population of Oregon are located in Wil-

s1 Reference: Piper, A. M., Ground-water Resources of the Willamette Valley, Oregon, US. Geol. Survey Water Supply Paper 890, 1942, 194 pp. 
lamette Valley, which is well supplied with surface water and does not draw heavily upon its ground-water reservoir. Current draft from wells is estimated to be at the rate of about 60,000 acre-feet a year.

The principal area of ground-water replenishment is in the south half of the valley. About one-third of the annual precipitation usually falls in December and January. In an average winter about 500,000 acre-feet goes into the groundwater reservoir. The draft from wells takes only a small part of this, and the rest is discharged to streams and by evapotranspiration during the year. This discharge is accompanied by a gradual recession of water levels in wells from April until the following December.

Snake River Plain, Idaho. ${ }^{32}$ The ground-water reservoir of the Snake River Plain is geologically composite. At many places it is in basalt, which commonly is so permeable that in the natural regimen it was drained readily by the Snake River. That river is deeply entrenched in the plain at most places below Minidoka Dam, and the water table before irrigation development was hundreds of feet below the land surface. Above Minidoka, in some reaches, the river was perched above the regional water table.

The use of the Snake River for irrigation on the Snake River Plain has had a variety of effects upon storage in the ground-water reservoir, depending upon the permeability

32 References: Stearns, H. T., Lynn Crandall, and W. G. Steward, Geology and Ground-water Resources of the Snake River Plain in Southeastern Idaho, U.S. Geol. Survey Water Supply Paper 774, 1938, $268 \mathrm{pp}$.

Stearns, H. T., L. L. Bryan, and Lynn Crandall, Geology and Water Resources of the Mud Lake Region, Idaho, U.S. Geol. Survey Water Supply Paper 818, 1939, 122 pp.

Nace, R. L., "Preliminary Report on Ground Water in Minidoka County, Idaho, with Special Reference to the North Side Pumping Division of the Minidoka Project," October 1948, 71 pp.; in U.S. Bur. Recl. Proj. Planning Rept. 15.53.1-1, Mimeo., April 1949. 
of the rock materials under the irrigated areas. Irrigation caused a considerable enlargement of Mud Lake, 30 miles northwest of Idaho Falls, which in 1900 was an intermittent pond never larger than 100 acres. By 1921, the lake had grown to 17,500 acres, with an additional 10,000 acres of swampy land around it. The lake and shallow ground water that forms it are perched more than 200 feet above the regional water table and have been built up largely by percolation from irrigation on the Egin Bench 30 miles away, which was first irrigated in 1905 . In recent years wells have been drilled to put this surplus ground water to use, with such success that the available supplies now may be overdeveloped.

Near Twin Falls, water was first diverted for irrigation in 1905. Prior to that time, the water table on the south side of the river had probably been more than 200 feet deep under most of the area. It rose as much as 25 feet a year in the first years of irrigation, and, until 1928, it was still rising several feet a year. Early in the 1920's many areas had become waterlogged, and drains and tunnels were constructed to keep the water table down. Rights have been established to the use of this drainage water for additional irrigation. It is estimated that about 6 million acre-feet was added to permanent ground-water storage from 1906 to 1928. In contrast, the water levels in wells north of the river from Milner to Bliss have risen only a few feet since irrigation was begun, although about 600,000 acre-feet of surface water is applied each year. Studies have indicated that the excess on that side percolates westward through permeable rock materials and is discharged from springs in the Hagerman Valley of the Snake River.

In southern Idaho there are several other places where the rocks underlying the irrigated area are impermeable enough to create drainage problems, including parts of the Boise, Weiser, and Payette Valleys and the Mountain Home area. There are also many areas where the underlying rocks are so permeable that the principal effect of irrigation has 
been to increase the discharge of springs. The famous Thousand Springs and other large springs along the canyon of the Snake between Milner and King Hill now discharge considerably more water than 50 years ago. In 1902, before irrigation, the total discharge of springs in this reach was about 3,800 second-feet. The average inflow to the Snake River between Milner and King Hill, derived chiefly from these springs, increased to 4,900 second-feet by 1910 , ranged from 6,800 to 7,600 second-feet between 1920 and 1940 , and has exceeded 8,000 second-feet since 1942. This increase results largely from return flow of irrigation water north of the river.

It has been estimated that under existing conditions of replenishment from irrigated lands and from natural sources, the ground-ivater reservoir under the Snake River Plain above King Hill could yicld 3,600,000 acre-feet annually, and the reservoir below King Hill might yield an additional 1 million acre-feet annually. The Minidoka project of the U.S. Department of Interior proposes to develop 241,000 acre-feet of this water over an 11-year period, with close observation of the effect of this development on the ground-water reservoir. The project involves irrigation of about 65,000 acres by pumping from 150 or more wells, each with a pumping capacity of 3 to 10 secondfeet.

Some of the ground-water reservoirs in the humid East appear to be nearer to full development than several of those described above, in spite of a notable advantage in precipitation. Perhaps the best example is the Rahway River Valley of New Jersey, which has a drainage basin of about 65 square miles, and furnishes up to 30 million gallons a day of ground water and 9 million gallons of surface water for industrial and municipal use. In dry seasons, very little water passes the lowest point of diversion. However, the outflow at other seasons is an indication that the valley has not yet passed the safe limit of development. 


\section{PROBLEMS OF MAXIMUM SUSTAINED DEVELOPMENT}

It is evident that the arid regions have ground-water reservoirs in almost every stage of development, from those practically unused and capable of considerable development to those capable of very little sustained perennial use and seriously overdeveloped. Many reservoirs are in areas where the land and other resources are eminently suitable for the enterprises of civilization, and those enterprises are limited only by the amount of water that can be made available perennially for their use. Eventually, every ground-water reservoir in the arid regions will doubtless be scrutinized to determine its capabilities in this respect, although attention to date has been concentrated on those areas where needs have been most urgent. A fundamental requirement for a satisfactory answer to this question is a knowledge of the locations and rates of replenishment and discharge over a sufficiently long period of time. With this information, comprehensive development for maximum utilization of the resource is possible. Enid, Okla., provides an example of full development of a ground-water reservoir where the limited potentialities of that reservoir have been recognized.

Enid, Okla. ${ }^{33}$ This city obtains its water from a groundwater reservoir in terrace sands and gravels north of the town. The terrace has an areal extent of 50 square miles, and under somewhat less than half that area the waterbearing materials are thick enough to yield water for municipal supply. The reservoir is replenished entirely by precipitation on the terrace. Experience has shown that the replenishment is enough to furnish about 2 million gallons a day and that this quantity can be obtained satisfactorily from wells spaced about half a mile apart. The requirements of the city have passed this limit, and Enid is planning to develop additional supplies, not by sinking more wells in the fully developed reservoir but by tapping other sources. s3 Reference: Schoff, S. L., "Ground-water Conditions in the Vicinity of Enid, Okla.," U.S. Geol. Survey, Mimeo. rept., 1949. 
Rapid development of ground-water resources, with accompanying land speculation and sudden influx of "settlers" is likely to be of the "boom and bust" type, in sharp contrast to orderly development seeking sustained perennial use of available water supplies. Three areas have been the scenes of greatly increased pumping as the result of post World War II development: in the Pecos River Basin of Texas about 88,000 acres of land is now being irrigated from wells, and pumpage probably exceeds 120,000 acre-feet a year; in the southern part of Escalante Valley, Utah, about 40,000 acrefeet was pumped in 1949; and in the Salt Flat Basin of Texas and New Mexico pumpage in 1949 was about 33,000 acre-feet. All these valleys have large quantities of water stored underground, and in all three the annual replenishment is known to be limited, but detailed studies have not been made to determine the quantity. Water levels in wells have been declining slightly during the early stages of development, and it is possible that pumpage already exceeds the average replenishment in all three areas. Smaller postwar developments in the Bluewater area and Animas and Playas Valleys in New Mexico have also caused declining water levels.

Escalante Valley, Utah. ${ }^{34}$ There are thousands of acres of arable land in Escalante Valley, of which about 10,000 acres is irrigated in the vicinity of Milford, both by gravity diversions from a reservoir on the Beaver River and by pumping from a ground-water reservoir which is replenished largely from the same stream.

In the southern part of the valley also, between Beryl and Enterprise, there are extensive areas of good land where ground water is within easy pumping distance. Since World War I, this area has been colonized by successive waves of White Russians, Japanese, and Californians, but real development did not begin until electric power lines reached the area during World War II. Prior to 1943 the

34 Reference: Fix, P. F., et al., Ground Water in Escalante Valley, Utah, Utah State Engr. 27th Bienn. Rept., pp. 109-210, 1951. 
draft on the ground-water reservoir was generally less than 3,000 acre-feet a year. The natural replenishment was ample for this amount of development, and in addition the natural discharge by evapotranspiration was of the order of 5,000 acre-feet, as shown by detailed studies in 1926 and 1927.

Since 1943, several new irrigation wells have been drilled each year, and pumpage has increased until in 1949 it reached about 40,000 acre-feet, applied to 12,000 acres of land. A substantial but unmeasured part of this water returns to the ground-water reservoir by percolation from irrigated lands, ditches, and the unlined reservoirs into which water is pumped prior to use. Nevertheless, there has been some depletion in ground-water storage, and since 1946 the water table has dropped 1 to 2 feet a year over extensive areas.

The areas of natural discharge by evapotranspiration are generally unsuitable for growing crops because of salt accumulation in the soil. Pumping in the newly developed areas can reduce this natural discharge only by lowering the water table sufficiently to prevent movement of water to the areas where the natural discharge occurs, a lowering which would be as much as 75 feet in some places. This method involves considerable depletion of storage, which means that pumping in the early stages of development can be at a rate substantially greater than the natural replenishment, and therefore greater than the yield which can be sustained perennially. It is possible also that the water now wasted by vegetation can be salvaged only by pumping from such great depths that the cost is prohibitive.

The state of Utah in 1946 proclaimed the southern part of Escalante Valley closed to additional appropriation of ground water for an indefinite period, not because the available water supplies were known to be entirely appropriated, but because time was needed to determine the effect of pumping from wells already completed or authorized for construction, and the relationship between draft and replenishment. Studies since that year have shown that 
pumpage has been considerably greater than the rate of replenishment and that water is being mined. The quantity of water in the ground-water reservoir is so large that pumping could continue at present rates for several decades, but certainly not forever.

Salt Flat Basin, Tex. ${ }^{35}$ Prior to 1947 ground water in the Dell City area of western Texas was used only for watering livestock and for supplying ranch headquarters. In the next three years there was rapid development for irrigation. By 1949 , 78 wells had been drilled, and 32 of these were used to irrigate about 6,000 acres of cotton and feed crops. Pumpage in 1949 is estimated to have been about 18,000 acre-feet. In 1948 and 1949 the water levels in wells declined at an average rate of less than half a foot a year.

Salt Flat Basin is a closed basin in an arid region, and is devoid of perennial streams. Water is pumped for irrigation from a cavernous limestone beneath the valley fill. The quantity of annual recharge to the ground-water reservoir has not been estimated. Natural discharge from the reservoir is by evaporation from lake flats having an area of 37,000 acres. The water table is less than 5 feet deep un. der much of these flats, and the natural discharge may well be several times as great as the pumpage in 1949.

Optimum development is achieved when the average replenishment is balanced by the average discharge and when the discharge for nonbeneficial purposes has been reduced to minimum. In most individual years, however, such a balance will not be achieved. Requirements for water for almost any purpose are likely to be more constant from year to year than the quantities of natural replenishment. When recharge is large, the precipitation and stream flow are likely to be above normal, so that the need for ground water may be less; and the need for ground water may be greatest in dry years,

35 Reference: Scalapino, R. A., Development of Ground Water for Irrigation in the Dell City Area, Hudspeth County, Texas, Tex. Board of Water Engrs. Bull. 5004, September 1950, 38 pp. 
as a supplement to low precipitation and stream flow. As with surface reservoirs, full use of a ground-water reservoir cannot be achieved by attempting to hold the storage at a constant level. Maximum use is achieved if some of the inflow of wet years is held in storage until dry years when there is greatest need for it. The use of ground-water reservoirs for holdover storage is well established in some valleys in southern California. San Fernando Valley in particular, because of the availability of surplus water from Owens Valley in some seasons, has been used for holdover storage of ground water.

San Fernando Valley, Calif. ${ }^{36}$ The San Fernando Valley ground-water reservoir is the property of the city of Los Angeles by the terms of an ancient Spanish grant, and pumpage by towns such as Glendale and Burbank or by private individuals is through the courtesy of that city. Los Angeles, too, has used that reservoir for water supply but in wet years uses it chiefly to store surplus water from the Owens Valley aqueduct and floodwaters from several flood-control projects. In those years, the recharge may exceed the discharge by several thousand acre-feet, as shown in the following table. The total capacity of the ground-water reservoir is unknown, but computations by the California Division of Water Resources indicate that more than 800,000 acre-feet can be stored in a zone 100 feet thick (extending above and below the water table of January 1933).

Estimated Input and Outflow of San Fernando Ground-water Basin, 1943 Input

Acre-feet

Recharge from rainfall penetration 73,000 Irrigation and domestic return water (imported from Owens Valley) 34,000 Water spreading and channel percolation .............. 69,500 Total input ........................ $\overline{\mathbf{1 7 6 , 5 0 0}}$ 36 References: Geology and Ground-water Storage Capacity of Valley Fill, South Coastal Basin Investigations, Calif. Div. Water Res. Bull. 45, 1934, 273 pp.

Blaney, H. F., and W. W. Donnan, "Ground-water Situation in San Fernando Valley, California," U.S. Soil Cons. Service, Mimeo. rept., December 1945, 56 pp. 
Estimated InPUt and OUtFlow of San Fernando Ground-iwater

BASIN, 1943 (continued)

Outflow

Acre-feet

Pumped or developed by city of Los Angeles ............ 55,700

Pumped or developed by other cities ................ 27,800

Pumped or developed by ranches, factories, and motion-picture

companies .................................. 10,000

Flow of rising waters past Narrows, Los Angeles River ....... 35,000

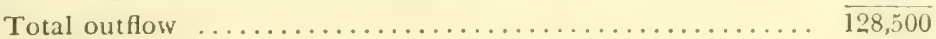

Precipitation in the years 1936 to 1943 averaged about 40 per cent above normal in the drainage basin, and the ground water stored in San Fernando Valley was increased considerably. In representative wells, the water levels in 1944 were 25 to 50 feet higher than in 1931. The increased storage was a valuable addition to the resources of the region, but the effects were detrimental in a few places. In some of the lower parts of San Fernando Valley, the water table rose to a position so close to the land surface that some lands were waterlogged and basements flooded. Following a survey of this situation in 1945 it was recommended that detailed studies be made to determine the best methods of control of the water table-whether by pumping or drainage canals or other means-which would permit maximum use of the valley's facilities for underground storage and yet would cause minimum inconvenience in the lower part of the valley.

Development of many ground-water reservoirs has already resulted in conflicts between the ground-water users and the holders of surface-ivater rights. Wherever a ground-water reservoir discharges into a stream, or vice versa, the utilization of water from that reservoir is likely to modify the natural pattern of stream flow. As development of these reservoirs progresses toward full utilization, the number of conflicts will inevitably increase. These problems are especially numerous along watercourses, where ground water and surface water are intimately related, and are discussed on pages 136-160. 


\section{Pipeline Problems}

The pipeline problems are problems chiefly of movement of water within an aquifer, rather than of replenishment to the aquifer. All developed aquifers serve not only as reservoirs to hold water but also as pipelines to carry water to the wells from the areas where it enters the aquifer (the recharge areas). The perennial yield of a well or group of wells is determined by the quantity of water that can move through the aquifer from the recharge area. If the transmissivity of the aquifer is inadequate, the water levels in wells will decline whether the aquifer as a whole is adequately recharged or not.

The public has little opportunity to appreciate how slowly water moves through aquifers. Houston, the largest city dependent on wells for municipal supply, is served by an aquifer with better-than-average capability for transmitting water. From the recharge area, 10 to 50 miles away, it takes a cross section of the aquifer 45 miles wide and 600 feet thick to transmit 80 million gallons a day to the Houston area, at a hydraulic gradient of 10 feet per mile. ${ }^{37}$ New York City obtains three times as much water from its Croton Reservoir, 24 miles away, through a pipeline less than 14 feet in diameter.

Problems of inadequate transmissivity of aquifers have developed in every part of the country. Pumping from a well or a closely spaced group of wells creates a hole, or technically a cone of depression, in the water table or artesian-pressure surface of the aquifer. Generally if withdrawal continues at a constant rate, this cone expands so that the well draws water from a progressively increasing area. The water level in the well continues to drop, but at a decreasing rate as time goes on, until the cone has expanded far enough to reach either an area of natural recharge or an area of natural discharge of the aquifer. Only when the pumping is balanced by increased movement from the recharge area or decreased natural dis-

37 Guyton, W. F., Application of Coefficients of Transmissibility and Storage to Regional Problems in the Houston District, Texas, Trans. Am. Geophys. Union, vol. 22, p. 767, 1941. 
charge, will the progressive decline of water level in the well be arrested.

The areas where significant cones of depression have been formed in the original water surface, whether water table or artesian-pressure surface, are shown on Plate III. The distinction as to whether approximate equilibrium has or has not been reached is strictly tentative, for a substantial increase in draft in any area will result in further lowering of water levels. In several areas, particularly coastal areas, the decline of water levels has been accompanied by encroachment of unusable water into parts of the aquifer.

Pipeline problems most commonly afflict cities and inclustrial areas that use large quantities of ground water, whether in humid or arid climate. Several of the areas of concentrated draft are within the overdeveloped reservoirs outlined on Plate II, and water levels are declining in them more rapidly than elsewhere in the reservoirs.

A general lowering of water levels over a broad area has been recorded in some aquifers where wells have been widely dispersed, resulting from a coalescing of the cones of depression formed by the individual wells. The conditions are superficially similar to those in overdeveloped aquifers where draft exceeds replenishment. There is the difference, however, that the developed areas are remote from the recharge area and that examination of the recharge area shows no depletion of storage there. The draft from wells, therefore, has exceeded the quantity of water that can move from the recharge areas to the wells, and the inadequacy is in the transmissivity of the aquifer rather than in the recharge.

The solution to the pipeline problems of apparent or local shortages of water is to bring the rate of draft into balance with the rate of replenishment, either by reducing the draft or increasing the replenishment, or both. Thus the principle is the same as that involved in the elimination of overdraft from reservoirs where long-accumulated storage is being progressively depleted. Since many of the apparent shortages are in humid regions which have water surpluses at least in cer- 
tain seasons, it has been possible to develop other ground-water or surface-water supplies and thus reduce the draft in the affected area. Other corrective measures that are effective in many areas are the development of wells in untapped portions of the aquifer or redistribution of wells to draw from a more extensive part of the aquifer. All these measures tend to reduce the concentrated draft upon a small portion of the aquifer.

Some ground-water shortages due to concentrated pumping have been overcome by artificial recharge, supplementing the natural recharge by spreading grounds, canals, or ponds. When the wells are remote from the recharge area, however, the limiting factor is commonly the transmissivity of the aquifer rather than the quantity of water available for replenishment of that aquifer. Helping nature then is no satisfactory solution. It is necessary instead to by-pass the natural circulation system and get the water into the aquifer in the area of use, where the shortage of water occurs. Recharge wells have been successful in such replenishment in some areas but sad failures in others, and it is evident that considerable development in the techniques of artificial recharge is needed.

Pumping itself increases the rate of movement from the recharge area to the wells, by increasing the hydraulic gradient. In several areas the water levels in wells have reached approximate equilibrium after years of pumping, indicating that the pumped water is now replaced by inflow of water through the aquifer. This solution is not satisfactory, however, where it requires pumping lifts so great as to make the cost of water prohibitive, or where the aquifer would be unwatered in the process of establishing a favorable hydraulic gradient. Obviously where pumping has created conditions favorable for inflow to the aquifer of unusable water, the situation will not correct itself by further pumping. The remedial measures for salt-water encroachment require either a reduction of pumping draft or the artificial replenishment of the aquifer where the storage is being depleted. 


\section{DISPERSED DEVELOPMENT REMOTE FROM}

\section{RECHARGE AREAS}

In most wells where water has traveled long distances underground from recharge areas, the water is confined under artesian pressure - that is, there is impermeable material above the aquifer at the wells which prevents recharge by downward percolation and confines the water as it moves from the recharge area toward the wells. The Dakota sandstone is an example of development of artesian wells in some cases as much as 300 miles from the recharge area. It furnishes water to thousands of wells distributed over an area of thousands of square miles, all remote from the recharge area.

Dakota Sandstone of the Northern Great Plains. ${ }^{38}$ Artesian wells have been developed in the Dakota sandstone throughout the Dakotas, northeastern Nebraska, western Minnesota and Iowa, and the initial pressure in some wells was great enough to operate water wheels for power. That was 40 to 70 years ago. With an estimated 10,000 wells reaching the sandstone in North Dakota alone, artesian pressures have dropped until many wells have ceased to flow, and the wells still flowing yield only a few gallons a minute.

As to quality, the water of the Dakota sandstone has notoriety rather than fame. Although the waters from some wells are soft and from others hard, practically all are too highly mineralized to meet the standards set by the U.S. Public Health Service for the rest of the nation. Many people make culinary use of the water, but they, like the brine shrimps in Great Salt Lake, have adapted themselves to water that their brothers and sisters in other regions would find extremely distasteful. The areas where the Dakota sand-

38 Reference: Wenzel, L. K., and H. H. Sand, Water Supply of the Dakota Sandstone, U.S. Geol. Survey Water Supply Paper 889-A, pp. 1-81, 1942. 
stone yields water to wells are not shown on Plate I, because of this inferior quality and because under present conditions most wells do not yield as much as 50 gallons of water a minute.

We still do not have complete information about the hydrology of the Dakota-sandstone aquifer. Most of the outcrops along the flanks of various mountain ranges seem unlikely places for recharge. For instance, several perennial streams rise in the Black Hills, but the channels are usually dry where they pass the hogbacks of Dakota sandstone, partly because of heavy seepage where those streams have crossed outcrops of cavernous limestones such as those in Wind Cave in South Dakota. Perhaps the geologic formation most deserving of fame for the artesian system is the overlying Cretaceous shale, so impermeable as to prevent the water in any of the underlying beds of limestone, shale, or sandstone from moving higher than the horizon of the Dakota sandstone. It is possible that the wells may have obtained water and minerals in solution from a considerably greater thickness of sediments than the relatively thin Dakota sandstone.

Detailed studies of the artesian conditions in the vicinity of Ellendale, N.D. were made in 1923 and 1938. In this area the first well drilled to the Dakota sandstone, in 1886, was 1,087 feet deep and florved 600 to 700 gallons a minute. The original pressure head was variously reported as 270 to 400 feet above the surface, as compared to a present position within a few feet of the land surface. Records indicate that the pressure declined about 12 feet a year from 1902 to 1915,4 feet a year from 1915 to 1923 , and less than a foot a year since 1923. In 1938 there were 815 wells in the Ellendale area, and the average flow was less than 3 gallons a minute. The discharge from the flowing wells had caused a drop of several feet in the artesian pressure of wells as much as 100 miles to the west, and the western limit of the belt of artesian flow moved eastward about 10 miles because of this 
decline. There was no evidence of decline of water table in the outcrop area, however.

The history of the development of the Dakota sandstone, therefore, is one of large initial yields from storage underground and progressive diminution in yield to a level determined by the transmission capacity of the aquifer. The conclusions from the studies at Ellendale were that water moves eastward in each 1-mile width of the aquifer at a rate of less than 100 gallons per minute. By 1938 the discharge from wells was only slightly greater than this amount, and conditions were approaching equilibrium.

The unbridled development of this reservoir was accompanied by prodigal waste of water taken almost entirely from storage within the reservoir. Compared with the great quantities discharged by wells in the past, the rate at which water can move eastward from the recharge area is very low. The annual draft from all wells in the reservoir is probably still declining slowly and will eventually reach a rate set by this transmission capability-a quantity which the reservoir can supply perennially to wells. Husbanding of the tremendous initial storage and artesian pressures in the aquifer would not have increased this ultimate yield. However, prevention of waste would have permitted withdrawal from storage over more extended periods and under greater artesian pressures.

There are very few ground-water reservoirs in which fresh water is known to have traveled as much as 100 miles from the recharge area, and most commonly the travel of water in artesian aquifers is 50 miles or less. The Dakota sandstone is thus exceptional. More typical are the deep sandstone aquifers of the Middle West from which some wells draw water that has traveled more than 80 miles from the recharge area. In the Chicago-Milwaukee area, heavy industrial draft has lowered the artesian-pressure surface more than 100 feet in an area of more than 2,500 square miles. 
Chicago-Milwaukee Industrial Area, Ill. and Wis. ${ }^{39}$ Ground water is used by many industrial plants in the Chicago-Milwaukee industrial area and also furnishes municipal supplies to several towns some distance from Lake Michigan. It is estimated that pumping from wells averages about 110 million gallons a day.

About 85 million gallons a day is pumped in the Chicago area, of which 65 million is pumped from sandstone aquifers 800 to 2,200 feet deep. The water in the sandstone was originally under sufficient artesian pressure to flow at the surface throughout the region, and the first deep well drilled in Chicago (in 1864) had sufficient pressure to raise the water 80 feet above the surface. Even today there are some flowing wells in southeastern Wisconsin, 30 or more miles from the areas of heavy pumping. In the Chicago-Joliet area pumping from deep wells started as much as 60 years ago; pumpage was about 30 million gallons a day in 1915 and 65 million in 1940. There has been little change in rate of pumping in the past decade. As greater and greater quantities have been pumped, artesian pressures have declined progressively, at an average rate of 6 to 8 feet a year for the past 40 years. By 1949 , concentrated draft in the southwest Chicago industrial district and Joliet, Ill., and at Milwaukee and Waukesha, Wis., had caused reductions in artesian pressure of 400 feet or more, and in several other areas the decline has been several hundred feet. Studies in the Chicago area indicate that these separate cones of depression have expanded and coalesced and that there is now an area of more than 2,500 square miles where artesian pressures have been reduced 100 feet or more. It is likely that this area

39 References: "Control of Ground Water," Illinois Legislative Council, Publication 88 , pp. 5-11, 1948. Also unpublished data of the Illinois State Water Survey.

Drescher, W. J., "Results of Pumping Tests on Artesian Wells in the Milwaukee-Waukesha Area, Wisconsin," Univ. Wis. and U.S. Geol. Survey Rept., 1948.

Chicago Area Water Supply (a symposium), Midwest Engr., vol. 2, pp. 6-21, February 1950. 


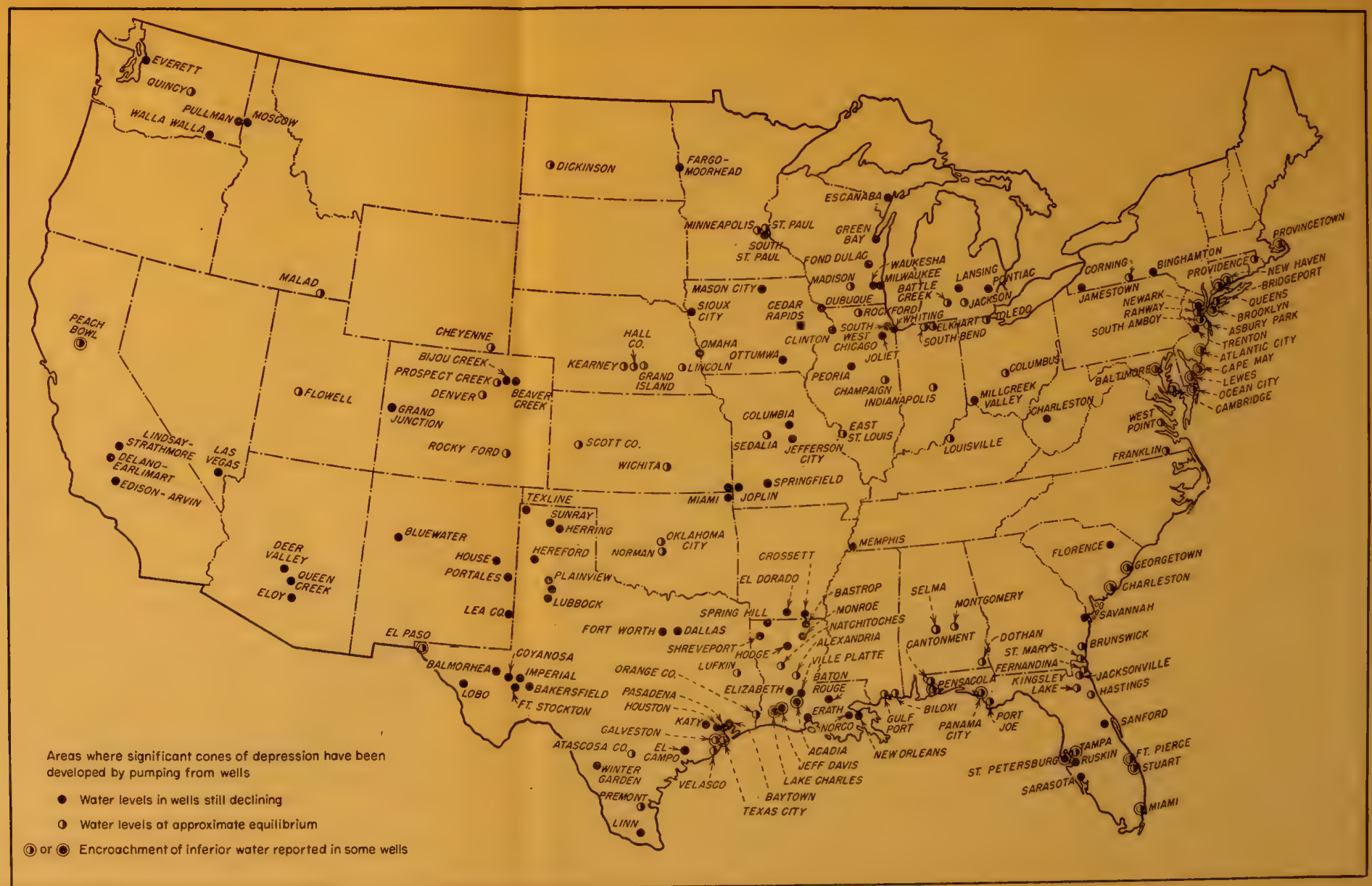



extends also into the Hammond-TWhiting area in Indiana, and possibly northward along the lake shore to Milwaukee.

At no place, however, are the deep sandstone aquifers being unwatered. Even in the southwest Chicago industrial district, where some pumps are set to lift water from depths as great as $825 \mathrm{feet}$, the artesian pressure is sufficient to raise the water above the top of the uppermost sandstone aquifer. Throughout the industrial area these artesian aquifers are still "full."

The recharge area for the ground-water reservoir is in south-central Wisconsin, more than 80 miles from the areas of concentrated draft. So far as known, water from precipitation is available for replenishment in the recharge area as fast as it can be transmitted toward the areas of draft. The areas in which artesian pressures have been lowered significantly extend at the most 30 to 40 miles out from the centers of heavy pumping, and it is unlikely that the pumping has induced any appreciable increase in rate of flow from the recharge area. The declining water levels show that pumping has been in excess of this rate of transmission through the sandstone, and partly at the expense of artesian storage. Water levels in wells will continue to decline until equilibrium is established either by decreased yicld or by increased movement of water from the recharge area.

Some pumping lifts in this region are the greatest to be found in the castern half of the country. Many industries are within areas served by public supplies taken from Lake Michigan (the cities of Chicago and Milwaukee are the principal examples) yet prefer to pump from wells. Whenever the cost of ground water becomes excessive, these industries can substitute the surface supplies, which are plentiful. The summer temperature of the lake water, sometimes more than $70^{\circ} \mathrm{F}$, makes it inferior to ground water for cooling and air conditioning, but it may be possible to recharge the deep aquifers through wells with cold lake water during the winter and pump that water out when needed.

As a means of relieving the shortage of municipal and in- 
dustrial water in Joliet and several other towns south of Chicago, it has been proposed to construct a 35 -mile aqueduct from Lake Michigan. The Illinois-Indiana Water Company was organized for this purpose in 1946, and the project has been approved by the states of Indiana and Illinois. The city of Chicago, Department of Public Works, also has proposed a plan for serving Lake Michigan water to some of the towns west and south of Chicago.

In the rice-growing areas where water is pumped from wells, it is almost certain that the ground water must have traveled some distance from the recharge area. It cannot be replenished within the rice-growing area, because rice requires a soil so tight that water can be ponded upon it. Thus very little downward percolation can be expected, and water pumped from underlying ground-water reservoirs can be replenished only by lateral movement from recharge areas some distance away. In the rice-growing regions of Arkansas, Louisiana, and Texas, large quantities of water are pumped from wells. A progressive decline of water levels in wells in the Grand Prairie of Arkansas (see page 49) and in southwestern Louisiana indicates that underground storage is being depleted and that water is not moving into the developed part of the aquifer as fast as it is being pumped out.

Lake Charles and the Rice Area, Louisiana. ${ }^{40}$ One of the areas of greatest ground-water development in the humid regions of the United States is in southwestern Louisiana. In 1948 about 650 million gallons a day was pumped from

40 References: Fisk, H. N., "A Geological Investigation of the Mississippi Alluvial Valley," Mississippi River Commission, Vicksburg, Miss., 1944, 78 pp. plus 33 pp.

Jones, P. H., Ground Water, An Advance Look at a Forthcoming Report by U.S. Geologists, Rice News, vol. 14, no. 10, 1947; Ground-water Summary, Rice News, vol. 15, no. 12, pp. 3-7, 1948.

Jones, P. H., and A. N. Turcan, Ground-water Use for Rice Irrigation in Southwestern Louisiana, Rice News, vol. 16, no. $1,1949$. 
wells-as much as 60 million gallons a day for industrial use in the Lake Charles area, and the rest for irrigation of rice. At Lake Charles the total withdrawal from wells was only 2 million gallons a day in 1935 , chiefly for public use. In the following 13 years the public demand increased to 6 million gallons a day, but the big increase in demand resulted from industrial developments that used 54 million gallons a day in September 1949.

The area of rice irrigation is a belt 20 to 50 miles wide that includes the Lake Charles area and extends eastward as much as 75 miles. About 600,000 acres of rice has been planted in this area annually for the past 10 years. Forty per cent of the total acreage, about 250,000 acres, is irrigated by water pumped from wells; possibly as much as 70 per cent is flooded by water originating as ground water, because part of the water pumped from wells is drained from the fields into ditches, bayous, and rivers, from which it is pumped to flood additional acreage.

The aquifers tapped by the large wells in southwestern Louisiana are considered to be alluvial fan deposits of freshwater origin. Most of these sediments are now below sea level, and since their deposition they may well have been covered for some time by the sea, permitting replacement of the original fresh water by salt water. The lower 200 feet of the aquifer, which in Acadia Parish is more than 900 feet thick, still contains salt water in some places. An important element in the geologic history of the region was the lowering of sea level by more than 400 feet during the most recent glacial epoch. This enabled the aquifer, deeply eroded by the Mississippi River and several coastal streams, to be flushed of whatever salt water it contained down to levels far below the present sea level. The aquifer now contains fresh water as far as 20 miles offshore to depths of about 1,000 feet, as shown by recent drilling of oil test wells.

Half a century ago the water in this ground-water reservoir was under sufficient artesian pressure to produce flowing wells throughout the rice-growing area and southward 
to the Gulf of Mexico. The principal recharge area is 10 to 50 miles north of the rice-growing area, where the permeable gravel and sand of the aquifer are at or near the surface, but there is also some recharge along stream valleys that have cut through the clay that covers the aquifer throughout the rice area. Precipitation in the recharge area is 55 to 60 inches a year, sufficient to replenish the groundwater reservoir as fast as water moves southward toward the pumped wells, and there has been no significant lowering of the water table in the recharge area since pumping began.

Pumping has created deep cones of depression in the artesian-pressure surface near Lake Charles and under the rice-growing areas to the east. That surface was below sea level under an area of about 4,000 square miles in September 1949, and more than 30 feet below sea level near Lake Charles and under some of the rice-growing areas to the east. In 1948, when the annual pumpage for all purposes was about 700,000 acre-feet, water levels in wells went lower than ever before; but these cones of depression have been deepening progressively at an average rate of about half a foot a year for at least the past 35 or 40 years because of pumpage. After seasonal pumping ceases, water levels rise in the center of each cone of depression while those on the flanks continue to decline for several weeks, indicating that the pumped water is replaced by inflow from all directions. Some of the water may also be replaced by upward movement, as suggested by the higher salinity of water from wells in the centers of the cones of depression. There may be some contamination of the aquifer from streams, which are salty in their lower courses during the late summer of dry years.

The ground-water problem in southwestern Louisiana appears to be due principally to the inability of the aquifer to transmit water from the recharge area in quantities sufficient to meet the demand of existing wells. Pumping has increased the hydraulic gradient from the recharge areas, and therefore the rate of movement of water toward the 
centers of pumpage. As pumping is continued, water levels will continue to decline until the inflow balances the withdrawal from wells, but there is danger that part of the inflow may be water of higher salinity. Some wells are already obtaining water of increased salinity, perhaps from the lower part of the aquifer. There is also the possibility of northward movement of saline water from the part of the aquifer beneath the Gulf of Mexico, but there is no proof yet of such encroachment. The aquifer is protected by thick, impermeable clay from direct intrusion of water from the Gulf of Mexico, except in the vicinities of the larger coastal streams.

\section{CONCENTRATED DRAFT FROM A PART OF A RESERVOIR}

The effect of pumping from a number of wells in a relatively small area is to develop a somewhat irregular depression in the water surface, formed by the coalescing of the cones of depression of individual wells. The depression is formed by the pumping and increases in clepth and extent if the rate of pumping increases. It also will dwindle and finally disappear after pumping ceases. Some war-emergency pumping projects have given us a complete history of the development and subsequent disappearance of such a cone of depression. At the Topaz Relocation Center in the Sevier Desert of central Utah, the artesian pressure was lowered more than 30 feet in an area of a square mile, and more than 5 feet in an area of 11 square miles, by pumping 2,900 acre-feet in three years from rather fine-textured aquifers in the valley fill. The cone was eradicated within two years after pumping had ceased, by slow movement of water within the reservoir. As another example, during the war the rate of pumping at Norman, Okla., increased from 2 million to 6 million gallons a day, and water levels dropped 130 feet in two years; after the cessation of pumping for war projects, water levels in observation wells rose as much as 97 feet but have since declined slightly, probably because of pumping from nearby wells.

The distinction here made between "concentrated" and 
"dispersed" development is recognized as arbitrary and is chiefly to set apart those areas where a redistribution of wells might solve the problem of excessive pumping lifts in the centers of existing cones of depression. Such redistribution would serve little or no purpose in the Dakota sandstone area, because pressure heads everywhere have been reduced so much. However, in the Chicago-Milwaukee area and in the rice areas there are localities of concentrated pumping within the broader region where water levels have declined. Wells in the centers of those deep cones of depression have far greater pumping lifts than those elsewhere in the region.

In several other localities large quantities of water are pumped from closely spaced wells, all at a distance several miles from the recharge area. Memphis, Tenn., El Dorado, Ark., and the Mill Creek Valley, Ohio, are listed as examples.

Memphis, Tenn., ${ }^{41}$ pumps about 10 million gallons a day, or about one-twelfth of its total water supply, from a sand aquifer 1,200 to 1,500 feet deep. Most of this water is pumped from wells within the city limits and about 50 miles from the recharge area. Since 1924 more than 50 billion gallons of water have been pumped out, and detailed hydrologic studies indicate that practically all has been taken out of artesian storage; for the cone of depression has not yet extended to the recharge area, and there has probably been no appreciable increase of inflow from that area. Water levels have declined about 50 feet in the past 25 years, but the quantity of water pumped out is small compared with the total storage in the reservoir. The water levels will continue to decline until the cone of depression has expanded to the recharge area and until the draft is balanced by increased inflow.

41 References: Schneider, Robert, and E. M. Cushing, Geology and Waterbearing Properties of the "1400-foot" Sand in the Memphis Area, U.S. Geol. Survey Circ. 33, 1948, 13 pp.

Kazmann, R. G., "The Water Supply of the Memphis Area," U.S. Geol. Survey, Duplicated rept., September 1944, 66 pp. 
Most of the water for Memphis is pumped from wells 250 to 600 feet deep. Water levels in these wells too have declined progressively over a period of years due to the concentration of pumping. The geologic conditions are such that the water in these shallow aquifers has probably not traveled so far from recharge areas as has the water in the "1400-foot" sand.

El Dorado, Ark. ${ }^{42}$ Here about 10 million gallons a day is pumped from a ground-water reservoir replenished at least 30 miles away. The water level has dropped more than 170 feet since 1921 and is now more than 30 feet below sea level in some wells, but still almost 200 feet above the top of the water-bearing formation. Since 1940 the rate of pumping has more than doubled, and water levels have declined at an accelerated rate. Most of the water has been taken from storage, and water levels will continue to decline until the draft is balanced by inflow from the recharge area. Here, however, there is unusable water in the formations above and below the developed aquifer, and the possibility that some may be drawn in as pumping continues.

Mill Creek Valley, Ohio. ${ }^{43}$ The small Mill Creek Valley, in the Cincinnati metropolitan area, presents the most serious ground-water problem in Ohio and is the more remarkable because all the localitics critically short of water are within 10 miles of major watercourses that yield abundant supplies to wells by river infiltration. In Mill Creek Valley and the adjoining Norwood trough, pumpage of water for industrial use averaged 21 million gallons a day in 1942 and in recent years has been about 17 million gallons

42 Reference: Baker, R. C., F. A. Hewitt, and G. A. Billingsley, Groundwater Resources of the El Dorado Area, Arkansas, Univ. Ark. Bur. of Research, Research Series 14, 1948, 39 pp.

43 Reference: Bernhagen, R. J., and E. J. Schaefer, Ground-water Conditions in Butler and Hamilton Counties, Ohio, 1946, Ohio Water Res. Board Bull. 8, 1947, 35 pp. 
a day. Some wells have been pumped for nearly 50 years, and in that period there has been a progressive decline of water levels in many wells.

Conditions are especially serious at Norwood, where water levels have declined more than 80 feet in 40 years. There a large proportion of the water has been taken from storage, and more than half the aquifer has been drained. At Ivorydale, conditions are almost as bad, for water levels have dropped as much as 75 feet in 55 years, and in places only the lower third of the aquifer is still saturated. At Carthage also the rate of pumpage is considerably in excess of the replenishment. At all three places the yields of wells have decreased as the pumping lifts increased and will be reduced further as water levels approach the bottom of the aquifer. At $\mathrm{II}^{+}$yoming there remains a greater thickness of saturated material, but pumpage has been greater than at the towns farther south, and water levels have declined as much as 25 feet in 10 years. Farther north in Mill Creek Valley, at Lockland and Sharonville, water levels have declined somewhat due to pumping, but there is considerable recharge from Mill Creek in flood, resulting in appreciable replacement of storage in some years.

Studies of the geology and hydrology have shown the reason for the large storage but comparatively low perennial yield of the ground-water reservoir in Mill Creek Valley and Norwood trough. Those broad valleys were formed and later abandoned by the Ohio River, and the ground-ivater reservoir is thus in the coarse sand and gravel deposited by a major stream. Recharge to this reservoir is limited now to quantities that infiltrate from precipitation on the valley and from small streams such as Mill Creek (total length about 25 miles). In the southern part of Mill Creek Valley, the ground-water reservoir is buried under impermeable clay. The replenishment to the wells at Wyoming, Carthage, Ivorydale, and Norwood is limited, therefore, not only by the recharge beyond the limits of the clay cap but by the rate at which water can be transmitted through the aquifer 
from those recharge areas, for distances as great as 7 miles in the case of Ivorydale.

Water spreading in recharge areas north of the clay cap would probably increase the supplies for Wyoming and Lockland, which are only a mile or two to the south. For Carthage and Ivorydale to be benefited by such a program would take years, plus a guarantee that Wyoming would not take the water as it goes by. All other corrective measures depend upon bringing water into the area from more adequate sources outside the valley. This was done successfully in 1943 for the war-emergency plant of Wright Aeronautical Corporation, built at Wyoming. When studies showed that its water requirement of 8 million gallons a day could not be met locally without aggravating a situation already serious, a well field was developed along the watercourse of the Miami River, and water was piped to the plant. Large supplies could be similarly developed elsewhere along the Miami or Little Miami Rivers, and brought in by pipeline. As an alternative, the feasibility of obtaining Ohio River water from the city of Cincinnati has been explored. Two industrial plants are already purchasing water during the winter when the temperature meets their needs and have reduced their pumping correspondingly.

It would be unfortunate if the ground-water reservoir in lower Mill Creek Valley were marked off as useless because it has not been adequate to meet demands to date. It is still a place where a large volume of water can be stored, and if the Ohio River (or other surface water) is eventually selected to serve the water needs of Mill Creek Valley, the inclustrial need for cool water would best be served by taking water from the stream in the winter, and storing it underground for year-round use.

Some areas of concentrated development are at no great distance from the recharge area, measured in miles, but the aquifers have been cut by barriers that prevent the free movement of water into the area of development. Thus a wedge- 
shaped part of an aquifer at Miami, Okla., is cut off from the rest of the aquifer. Pumping tests have demonstrated the existence of similar barriers in parts of the limestone aquifers of western Ohio. These geologic barriers are sometimes responsible for sharp decreases in yields of wells after they have been pumped for a while.

Miami, Okla.44 Wells yield copious water supplies from sandstone and limestone aquifers in northeast Oklahoma and adjoining areas in Kansas and Missouri. In some parts of the area, wells are so closely spaced that they have interfered markedly with one another, and there are indications of local "overdevelopment." On the other hand, these aquifers are capable of transmitting large quantities of water, as shown especially in several mines where millions of gallons of water must be pumped out daily in order to continue mining operations, and it is likely that large quantitics of water are still available for development by properly spaced wells.

At Miami a wedge-shaped portion of the water-bearing Roubidoux sandstone is partly cut off from the rest of the aquifer by the Seneca fault and the Miami trough, which act as barriers to ground-water morement. Wells pumping about 2 million gallons a day from the sandstone within this wedge have created a cone of depression which expanded as far as the barriers and could expand no farther. There has been an accelerated decline in artesian pressure in recent years. In a Miami city well that had flowed in 1907 the pressure dropped at a rate of about 6 feet a year until 1937, when it was 180 feet below the surface. In the following 10 years the pressure dropped 230 feet farther, at a rate of about 23 feet a year. The accelerated decline in water level since 1937 may be attributed in part to the effect of these barriers, and in part to increased pumping from the aquifer. Current pumping is undoubtedly greater than replenishment within

44 Reference: Schoff, S. L., "Ground-water Supplies and Uses in Oklahoma," 3rd Annual Wild Life Conference, June 1918. 
this wedge because of these barriers, but there is additional water available for development outside the wedge-shaped area.

In relation to quantity of water pumped, the greatest declines of water table or artesian pressure occur generally in ground-water reservoirs with the poorest capabilities for transmission of water. As an example, Dickinson in western North Dakota meets its water requirements (600,000 gallons per day) with difficulty by pumping from wells in a poorly permeable sandstone. Pumping from seven wells had lowered the water table more than 80 feet by 1943, and the yield dropped so that it was necessary to restrict the use of water. There was very little change in water levels, however, from 1943 to 1947, and it appears that the rate of movement toward the wells in recent years has been approximately equivalent to the pumpage. As another example, sandstone aquifers of low permeability are pumped heavily at Dallas and Fort Worth, Tex.

Dallas and Fort Worth, Tex. ${ }^{45}$ About 16 million gallons a day is pumped from wells for industrial use at Dallas and Fort Worth, and in addition about 18 million gallons a day is pumped for public use from the same aquifers to the north and south. The water in these aquifers was originally under sufficient artesian pressure to flow at the surface, but pumping has lowered the water levels as much as 500 feet in the business district of Fort Worth, and nearly 300 feet at Dallas. The recharge area is 20 to 40 miles west of Fort Worth. The aquifers have low permeability and consequently limited ability to transmit water, with the result that large declines in artesian pressure have occurred in all localities where the draft on underground reservoirs has been heavy.

The total water requirements of the Dallas-Fort Worth area are far beyond the capabilities of the ground-water

45 Reference: "Water Facts in Relation to a National Water Resources Policy," U.S. Geol. Survey, Mimeo. rept., Appendix C, p. 112, April 1950. 
reservoir, and most of the public supplies are obtained from surface water. Five reservoirs on the Trinity River and its tributaries have a combined storage capacity of about 2 million acre-feet, and five others under construction will increase this storage by 1,600,000 acre-feet. Even this storage does not represent full development of the Trinity River potential.

In many areas of concentrated draft water levels have declined very little in recent years, and the present rate of pumping appears to be approximately in balance with the rate of inflow to the cone of depression.

Rockford, Ill., ${ }^{46}$ pumps about 25 million gallons a day from a sandstone aquifer for municipal and industrial use; artesian pressure there declined about 24 feet from 1891 to 1938 but dropped no further in the next 10 years. More than 30 million gallons a day is reported to be discharged from the aquifer into streams, and it is evident that a substantial increase in pumpage would be practicable in the Rockford area.

Jacksonville, Fla., ${ }^{47}$ has until recently obtained its water from a limestone aquifer by free flow, in order to be certain that there should be no salt-water intrusion in its municipal supplies from deep brine-bearing limestone. In the past 15 years artesian pressures at Jacksonville have declined only 3 feet, although current withdrawals are at a rate of about 50 million gallons a day. The total decline since wells were first drilled is about 25 feet.

46 Reference: Smith, H. F., and T. E. Larsen, "Ground-water Resources in Winnebago County," Ill. State Water Survey Rept. of Invest. 2, 1948, 33 pp.

47 References: Cooper, H. H., Jr., Ground-water Investigations in Florida, with Special Reference to Duval and Nassau Counties, Jour. Am. Water Works Assoc, vol. 36, pp. 169-185, 1944.

Cooper, H. H., Jr., and M. A. Warren, The Perennial Yield of Artesian Water in the Coastal Area of Georgia and Northeastern Florida, Econ. Geol., vol. 40. pp. 263-282, 1945. 
Madison, Wis., ${ }^{48}$ pumps about 12 million gallons a day from wells for municipal supply. The static artesian pressure in the center of the cone of depression has declined about 55 feet since 1882, but pumping levels in the widely separated municipal wells have not dropped appreciably since 1922.

Minneapolis and St. Paul, Minn. ${ }^{49}$ The Twin Cities obtain their public supplies from surface water, but probably more than 50 million gallons a day is pumped from private wells, chiefly for air-conditioning and industrial use. Practically all this ground water comes from a sandstone more than 300 feet below the surface in the areas of greatest draft. As a result of pumping, artesian pressure has declined about $60 \mathrm{feet}$ in the heart of Minneapolis, which is 10 miles from the recharge area, and as much as 100 feet in the South St. Paul industrial district, twice as far from the recharge area. The shape of the cone of depression under Minneapolis is indicated by declines in artesian pressure amounting to 30 feet at distances of $2 \frac{1}{2}$ miles from the downtown district, and only a few feet in the suburbs; in the part of the recharge area nearest to Minneapolis the water table has dropped slightly, but no decline has been shown in wells near Lake Minnetonka, farther west along the recharge area. Within this cone of depression the rate of decline has been less in the past decade than it was prior to 1940, and water levels were practically the same in April 1950 as in April 1949. Thus, inflow appears to be about equal to the rate of pumping draft. In St. Paul, water levels declined as much as 50 feet prior to 1925 , when the city depended upon wells for part of the municipal supply, but have risen somewhat in the past two decades. In South St. Paul, water levels are still dropping at appreciable rates, partly because of increasing draft.

48 Reference: Foley, F. C., Personal communication.

49 Reference: Bradley, Edward, "Artesian Water Supply of the Twin Cities Basin,” Minn. Geol. Survey, Mimeo. rept., 1949, 18 pp. 
The sandstone carries more water than is being pumped and discharges it into the Minnesota and Mississippi Rivers. This water could be developed by additional wells, preferably near the recharge area and in any case away from the cones of depression formed by existing welis.

Oklahoma City, Okla..$^{50}$ Most of the ground water used in the Oklahoma City area is pumped from bedrock aquifers by industry and by several smaller towns for public supply. About 6 million gallons a day is pumped from wells, some of which are as much as 800 feet deep. The sandstone aquifers have a relatively low permeability, and pumping has therefore produced large and deep cones of depression. The water in the sandstone is under artesian pressure originally sufficient to raise water to within 100 feet of the surface in Oklahoma City. During World War II, water levels in wells throughout the area declined as a result of increasing pumpage and by 1944 were as much as 230 feet below their original positions in some wells, when more than 8 million gallons a day was pumped for industrial use. With the conclusion of the war, the total pumpage decreased somewhat due to closing of certain war installations, and water levels in observation wells have not changed greatly in the past five years. At present it is considered that the rate of pumping is not greater than the rate at which water can be transmitted through the sandstone from the recharge area to the wells.

The public supply for Oklahoma City comes from the North Canadian River and is stored in two reservoirs: Lake Overholser with a capacity of 17,000 acre-feet, and the offstream Lake Hefner, with a capacity of 76,000 acre-feet. At present rates of consumption those two reservoirs can hold about a four-year supply for the city. Before the completion of Lake Hefner in 1944, however, the city faced shortages of water whenever the flow of the North Canadian

50 Reference: Jacobsen, C. L., and E. W. Reed, Ground-water Supplies in the Oklahoma City Area, Okla., Okla. Geol, Survey Mineral Rept. 20, 1949. 
River dropped moderately below normal, because of the meager storage afforded by Lake Overholser. In 1939 and 1940 , and again in 1943, droughts caused severe shortages in the supply, and for relief in these emergencies the city pumped 3 to 4 million gallons a day from 15 wells along the North Canadian watercourse. Preliminary studies indicate that several million gallons a day of ground water could be pumped from this watercourse. The quality is inferior to surface-water supplies, however, and the wells are not likely to be used by the city, except during emergencies. The water is used for irrigation and is suitable for some industrial uses.

In several other cities water levels in wells have been dropping rapidly in recent years, and since the rate of pumping has been increasing, the decline is attributed largely to that increase.

Fond du Lac and Green Bay, Wis. ${ }^{51}$ In Fond du Lac the static water level in one well has dropped 5 feet a year since 1946, and artesian pressures are generally 200 feet lower than in 1900. And in Green Bay, where some wells once flowed by artesian pressure, 10 million gallons a day is now being pumped, and water levels are now as much as 300 feet below the surface. The pumping in both cities is from wells within the city limits, and distribution of wells over a wider area would provide the same quantity of water with less pumping lift. Hydrologic studies are needed to show whether the sandstone aquifer can satisfy the erentual needs of the communities, or whether pipelines from Lake Michigan or other sources may ultimately be necessary.

Lansing, Mich. ${ }^{52}$ About 25 million gallons a day is pumped from sandstone aquifers, and artesian pressures have declined more than 50 feet in some wells. Pumpage

51 Reference: Foley, F. C., Ground Water, in "The Sciences and Conservation," Univ. Wis. Centennial Conference on Conservation, 1949.

52 Reference: Ferris, J. G., Personal communication. 
currently is about 50 per cent greater than in 1945, and the city's demands are continuing to increase. However, Lansing can develop large additional supplies from the watercourses of the Red Cedar and Grand Rivers.

Local ground-water shortages have developed in many cities because of progressively increasing requirements of expanding population and industry, rather than because of failure of wells to meet continuing demands. Some cities have met their increasing needs and yet have reduced the pumping lift in the city wells by development of new well fields outside the areas affected by the pumping of the older wells. Alexandria and Natchitoches, La., have developed new well fields within the last few years. Wider spacing of wells would certainly ameliorate the apparent shortage at Baton Rouge, La., where 45 million gallons a day is pumped from a shallow aquifer, mostly from 40 large wells with in an area of 2 square miles. In this aquifer the artesian pressure has dropped as much as 230 feet since 1914.53

Montgomery, Ala., for several years obtained its public supplies by flow from artesian wells drilled in 1886, but pressures declined until by 1899 all supplies were being pumped, and water levels in those wells are now more than 100 feet below the surface. A new well field west of the city is now providing about 4 million gallons a day from the same aquifers, but these wells are outside the deep cone of depression formed by the older wells. Supplementary supplies have also been obtained since 1937 from wells drilled in the alluvium along the Alabama River, and more ground water could doubtless be developed from that watercourse.

Many cities, like Lansing, Mich., and Montgomery, Ala., are located along watercourses which could provide large additional supplies of ground water. In Canton, Ohio, for instance,

53 Cushing, E. M., and P. H. Jones, "Ground-water Conditions of the Baton Rouge Area, Louisiana," La. Dept. Publ. Wks., Mimeo. rept., 1945, 37 pp. 
ground-water levels declined steadily throughout World War II, and the situation became so serious that one of the large industries started conservation measures that reduced the pumping enough to halt the declining trend. The city has also developed ground-water supplies from the watercourses of the west and middle branches of Nimishillen Creek, which now furnish about 12 million gallons a day (page 147). Since 1945, the trend of water levels in wells within the city has been upward. At Shreveport, La., many deep wells have been abandoned because of declining water levels; there the watercourse of the Red River has been recommended as a plentiful source of hard water suitable for cooling and air conditioning.

One of the outstanding areas of concentrated ground-water draft in the country is that around Houston and Galreston, Tex., where total pumpage from artesian ground-water reservoirs approaches 300 million gallons a day.

Houston and Galveston, Tex. ${ }^{54}$ Houston, with a population of 594,000 in 1950, is the largest city in the country dependent upon ground water for all municipal and most industrial uses. The artesian ground-water reservoir that supplies the city is heavily developed by wells distributed over a wide area. In Houston and the Pasadena industrial area to the east, pumpage from wells has increased from 50 million gallons a day in 1930 to 80 million in 1940 and to about 150 million gallons a day in 1949. Since 1940, water levels in wells have declined more than 70 feet in downtown Houston and 100 feet near Pasadena. In this area a broad cone of depression has formed. Water levels are now below sea level throughout an area of more than 500 square miles, and at Pasadena they are more than 150 feet below sea level. However, the amount removed from storage is shown by detailed hydrologic studies to be small in 54 References: Texas Board of Water Engineers, Progress rept. for period Sept. 1, 1946-Aug. 31, 1948, pp. 127-131, 1948.

Lang, J. W., and A. G. Winslow, Geology and Ground-water Resources of the Houston District, Texas, Tex. Board of Water Engrs. Bull. 5001, October 1950, 36 pp. 
comparison to the vast quantity pumped in the past 20 years. Instead of indicating the exhaustion of the ground-rvater reservoir, the lowering of water levels is the result of decline of artesian pressure, and it is because of this decline that there is now far more inflow into the heavily pumped Houston area than before development began.

Recent studies have shown that the encroachment of salt or brackish water from horizons below the fresh-water bearing sands or by invasion from the direction of the Gulf is not likely to occur at least for many years. Observations since 1930 have shown no significant change in mineral content of water pumped from representative wells; drilling has shown that fresh water can be obtained from depths as great as 2,500 feet in Houston. Thus the most serious aspect of the lower pressure is the increasing cost of pumping the water. This cost, plus the realization that the ground-water reservoir is perhaps already doing more than its share in meeting the rapidly expanding requirements for water, has led many industries to turn to surface-water supplies. In 1949, the Pasadena industrial area used 30 million gallons a day from the San Jacinto River, and storage reservoirs are being planned for increasing the supply.

About 25 miles west of Houston, and closer to the recharge area, is the Katy rice-growing district, where water is pumped from the same ground-water reservoir that supplies Houston. Here, too, pumpage has increased, from about 18 million gallons a day in 1930 to 100 million in 1949, and water levels in wells have been lowered 10 to 25 feet in the past 20 years. The ground-water reservoir is recharged by precipitation in areas 12 miles or more northwest of Katy. In the recharge area the water table has shown no material decline during the last decade, indicating little or no net loss in storage in the recharge area. The declines in artesian pressure at Katy, as at Houston, are obviously not due to deficient replenishment in the recharge area, but to the slow rate at which water is transmitted from there to the wells. 
Galveston, Texas City, and Baytown are 30 to 50 miles southeast of Houston and depend upon a different and geologically younger aquifer for their ground-water supplies. On Galveston Island, the water in that aquifer is too saline for most uses, and the city pumps water from wells on the mainland. The wells in its Alta Loma well field, about 18 miles northwest of Galveston, yielded about 5 million gallons a day in 1935, but as pumpage increased the water increased in salinity. In 1943, a second well field was developed a few miles farther inland. Galveston City now pumps about 10 million gallons a day from both fields. Texas City has also had trouble with salt-water encroachment, particularly in 1945 when more than 22 million gallons a day was being pumped. In 1948 facilities were completed for utilizing the water of the Brazos River, and pumpage from wells in the past two years has declined somewhat. At Baytown the wartime pumpage of 17 million gallons a day has been reduced since the utilization of San Jacinto River water by some industries. The total pumpage in those three areas reached a peak of more than 45 million gallons a day in the later years of World War II; water levels declined until they were more than 85 feet below sea level in some localities, and several wells began pumping water of increasing salinity. Fortunately surface-water supplies are available to the area in the Brazos and San Jacinto Rivers. The utilization of about 23 million gallons a day from the Brazos River since 1948 has resulted in substantial reduction in pumpage from wells, and artesian pressures of the deeper wells have risen in the past two years.

\section{THE DANGER OF DRAWING UNUSABLE WATER INTO THE}

\section{RESERVOIR}

Intensive development of portions of several ground-water reservoirs has lowered the water table or artesian pressure sufficiently to induce the inflow of unusable waters, either from the ocean or from rock materials impregnated with mineralized water. Ocean water has been drawn into the 
ground-water reservoir under Brooklyn, at the western end of Long Island, New York, but the water table has been rising in recent years and may eventually rise sufficiently to be a problem in some basements and subways constructed several years ago. Provincetown, on Cape Cod in Massachusetts, has solved a similar problem of salt-water encroachment by pumping at reduced rates, especially when the water table is low. Thus controlled, the wells furnish a continuous supply of fresh water, although some are within 800 feet of the ocean.

Brooklyn, N.Y. ${ }^{55}$ Brooklyn occupies the western tip of Long Island, which has an areal extent of about 1,300 square miles and is bordered on all sides by salt water. The ground-water reservoir underlies practically all the island and is dependent for its natural replenishment upon the precipitation that falls on the island. So humid is the climate and so permeable the surficial materials of the island that the replenishment is estimated to average a billion gallons a day or more. The ground water moves toward the edges of the island and is discharged into the ocean, either directly from the sands and gravels or through the numerous streams fed from the ground-water reservoir. Fresh water has been obtained from wells right along the strand line of the island, and even along the barrier beaches.

In Brooklyn, the island is only 6 to 8 miles wide between the East River and Jamaica Bay. Here, too, water levels were originally above sea level, as shown by a water-table map based on data collected in 1859. By 1932, however, heavy draft for industrial and public use had lowered water levels below sea level under the northern half of Brooklyn. The

55 References: Brashears, M. L., Artificial Recharge of Ground-water on Long Island, N.Y., Econ. Geol, vol. 41, pp. 503-515, 1946. Jacob, C. E., The Water Table in the Western and Central Parts of Long Island, New York, N.Y. W'ater Power and Control Commission Bull. GW-12, 1945, 24 pp.

Lusczynski, N. J., "Withdrawal of Ground Water and Pond Water on Long Island from 1904 to 1949," U.S. Geol. Survey, Typed rept., 1950, 3 pp. 
center of this cone of depression, in downtown Brooklyn, was more than 15 feet below sea level. By that year, salt water had moved in from Jamaica Bay and from the East River and appeared in many pumped wells.

Legislation passed at this time required permits for draft of more than 100,000 gallons per day from new wells, and these permits were issued with the proviso that water used for cooling and air conditioning be returned to the same aquifer through recharge wells. Since these regulations did not apply to existing wells, the beneficial effect upon the ground-water reservoir was delayed until a sufficient number of the old wells had been abandoned or required replacement. Water levels continued to decline gradually until 1941, when the cone of depression was more than 25 feet below sea level under an extensive area, and locally as much as 50 feet below sea level, and water levels were below sea level under three-quarters of Brooklyn and several square miles of neighboring Queens borough. The water table rose gradually from 1941 to 1947 and at an accelerated rate in succeeding years.

Prior to 1917, all the public supplies for Brooklyn and Queens came from ground water on Long Island, and the draft reached an average 189 million gallons a day in 1916 , of which about half was pumped from wells within the two boroughs. In 1917 these boroughs were connected to New York City's Catskill supply. The ground-water pumpage dropped to less than 50 million gallons a day in 1918, increased again to more than 100 million gallons a day in 1931, and then trended gradually downward. Since 1947 there has been no pumping for public use in Brooklyn, and industrial pumpage has been about 30 million gallons a day. In Queens borough, pumpage in 1949 was about 60 million gallons a day, of which about one-fourth was for industrial use.

Brooklyn's ground-water troubles have been aggravated by its dearth of open spaces. About half of its 70 square miles is covered by buildings and pavements, and the precipita- 
tion which might replenish the ground-water reservoir under natural conditions goes instead to storm sewers and quickly out to sea. It is estimated that about 35 million gallons a day of potential recharge is thus rejected in Brooklyn, and probably an equal amount is lost to the ground-water reservoir in neighboring Queens borough. Currently the pumpage in Brooklyn and Queens (less than 100 million gallons a day, of which perhaps a third is returned through recharge wells) is adjusted to this urban condition, and water levels are rising appreciably. Indeed, Brooklyn has made several adjustments to ground-water conditions in recent years. Many wells that pump salt water are used only for cooling or air conditioning, and the salinity is detrimental only to the equipment through which the water circulates. The St. George Hotel in downtown Brooklyn, after drilling wells and developing salt water, has turned the situation to advantage in advertisements of its salt-water swimming pool. The depressed water table has permitted construction of basements and subways at levels that will invite secpage if the water table recovers its position of four decades ago.

Throughout Brooklyn's ground-water travails, the Long Island ground-water reservoir has been discharging more than 700 million gallons a day unused into the ocean, and only a very small amount has been diverted toward the cone of depression at the west end of the island. In 1950, it is estimated that not more than 300 million gallons of ground water a day was used (including 100 million for New York City during its shortage), and of that more than 120 million gallons was returned to the reservoir through recharge wells and basins. In addition, the treated scrage effluent from many communities in central Nassau County goes into the ground-water reservoir. The county-wide sewer system now under construction will instead dump that water directly into the ocean, which appears to represent a step backward in ground-water conservation. 
New Jersey, with much of its border formed by salt water, has several places where salt water has encroached into well fields and many others where ground-water development proceeds softly for fear of inducing salt-water intrusion. In spite of its small size, the state ranks ninth in the Nation in quantity of water pumped from wells, and it is believed that New Jersey has made a more nearly complete development of its groundwater reservoirs than any other state in the humid regions. This development has caused the water table or artesian pressure to decline below sea level in many places. In Newark, where 20 million gallons a day is pumped from wells, water levels in unused wells are as much as 240 feet below sea level, and the salt content has increased in many pumped wells, especially in the vicinities of Newark Bay and the Passaic River. ${ }^{56}$ Some industrial wells have been recharged artificially with marked success, using winter surpluses from Newark's municipal surface-water supplies. ${ }^{57}$ In Atlantic City pumping from shallow wells has brought in water from nearby salt marshes. At Parlin and Cape May the dredging of ship channels has rendered shallow ground-water reservoirs accessible to entry of ocean water, and wells pumping from below sea level have yielded water of increasing salt content.

In many of the state's ground-water reservoirs no increase in salt water has yet been noted in producing wells, but there is concern lest continued pumping from below sea level may favor such encroachment. This is true of the artesian reservoirs that provide water to most of the coastal cities, including Atlantic City, Asbury Park, and many others. Several of these cities have piped water from wells several miles inland, where there is less possibility of salt-water intrusion.

Probably all ground-water reservoirs in New Jersey refuse

56 Herpers, Henry, and H. C. Barksdale, "Preliminary Report on the Geology and Ground-water Supply of the Newark Area, New Jersey," U.S. Geol. Survey rept., in press.

57 Erickson, E. T., Using Runoff for Ground Water Recharge, Jour. Am. Water Works Assoc., vol. 41, pp. 647-649, 1948. 
some recharge at times of heavy precipitation, simply because storage space in their recharge areas is used up. The problems of cleclining water levels and in some places of resulting saline encroachment are, therefore, due chiefly to the slow transmission of water from these recharge areas to the points of use. Artificial recharge from ponds has been attempted with marked success by the Perth Amboy Waterworks and the "Duhernal" companies (du Pont, Hercules Powder, National Lead). By ponding stream flows, it has been possible to add as much as 15 million gallons a day to a ground-water reservoir in Middlesex County.

Atlantic City, N.J..$^{58}$ Atlantic City is justly proud of its salt-water attractions and has long been aware of the possibility of contamination of its fresh-water supplies by the salt water. Ground water, which has always been the predominant source of supply, has been studied intensively, and since 1923 careful watch has been maintained to detect any encroachment of salt water into the fresh-water supplies.

The city has obtained its ground-water supplies from three aquifers. The shallowest ("100-foot sand") is most susceptible to salt-water intrusion, for it lies at rather shallow depth beneath salt-water marshes and lagoons. Three of the five municipal wells drilled in this aquifer in 1930 were abandoned shortly thereafter because of inflow to the wells from nearby salt marshes, and other wells in the aquifer are generally held in reserve and pumped only to meet peak demand. The next deeper aquifer ("200-foot sand") furnishes a large proportion of the water supplies, particularly from wells near its recharge area, which are farthest from salt water.

The principal aquifer at Atlantic City is the deep (" 800 foot") sand. On the mainland this aquifer yields water of

58 Reference: Barksdale, H. C., R. M. Sundstrom, and M. S. Bronstein, "Supplementary Report on the Ground-water Supplies of the Atlantic City Region," New Jersey State Water Policy Commission Special Rept. 6, 1936, 132 pp. 
better quality than the shallower aquifers, and it is the only one yielding fresh water to wells on the barrier beach, for the Boardwalk and communities on the open ocean. Wells in this aquifer originally flowed by artesian pressure in Atlantic City and at many other places along the coast. Pumping has reduced the pressure more than 50 feet in extensive areas and more than 100 feet in Atlantic City, so that water levels in some wells are more than 75 feet below sea level. The aquifer is protected from direct salt-water encroachment from the ocean by overlying clays, but water undoubtedly moves into this deep cone of depression from the part of the aquifer now under the ocean, and it is not known to what extent that aquifer contains fresh water.

During the Ice Age, when sea levels were several hundred feet lower than today, fresh water may have moved through the aquifer for some distance east of the present shore line. The eastward extension of the aquifer, however, is evidently not now open to the ocean, for, if it were, the 800 -foot sand at Atlantic City would probably already have a higher proportion of salt. The present analysis of the situation at Atlantic City is that the 800 -foot sand, before pumping commenced, had water under sufficient artesian pressure to move upward through the "confining" clays and discharge at the land surface or into the ocean not very far away from the present shore line. This natural discharge has been eliminated in many places by lowering of the artesian pressure below sea level, and the water instead is pumped from wells. Thus there is a possibility of a substantial perennial yield without salt-water contamination, even though the artesian pressure is below sea level. Until there is indication of increasing salinity in the easternmost wells, the draft may be presumed to be within the limit of this perennial yield.

Salt-water encroachment presents many problems in the vicinity of Baltimore, Md. Although as a general rule cessation of pumping is a corrective to salt-water encroachment, there are areas around Baltimore where it is advisable to con- 
tinue pumping shallow water to prevent contamination of a deeper aquifer, and also places where it may be advisable to pump the deep aquifer to remove contaminated water and prevent it from moving to areas where the water is still usable. Finally, a major industrial use of the water is for cooling, and for that purpose the saline ground water is usable and may be preferable to municipal supplies that could be substituted. Thus high mineral content is not a deterrent to some users of the water.

Baltimore, $M d .^{59}$ Prior to the construction of a public surface-water supply in 1808, the people in Baltimore obtained their water from springs and shallow dug wells. The first artesian wells were drilled in the Baltimore Harbor district in 1853, and by 1860 there were nearly a hundred flowing wells. By the latter part of the nineteenth century wells were decreasing in yield, and there were reports of salt-water contamination. The use of ground water increased more or less progressively until 1940, but the localities of greatest pumpage shifted io areas along the Patapsco estuary, and practically all the wells in the harbor district were abandoned because of contamination by salt or acid waters. Pumpage reached a total of about 47 million gallons a day in 1940 and 1941 but dropped to about 34 million late in 1912. This decrease was chiefly at the Sparrows Point plant of Bethlehem Steel Company, which began using treated sewage effluent for its increasing requirements and as a substitute for the water formerly pumped from wells. Since 1943 the annual pumpage in the Baltimore area has probably changed only slightly from year to year. Practically all the ground water pumped in the past 50 years has been used by industries.

59 References: Bennett, R. R., Ground Water in the Baltimore Area, Md., Maryland Board of Nat. Res. Educ. Ser. 13, 1946, 15 pp.

Bennett, R. R., and R. R. Meyer, "Geology and Groundwater Resources of the Baltimore Area, Maryland," U.S. Geol. Survey rept., in preparation. 
Water levels in wells declined as pumpage increased, and in the various centers of heavy pumpage they reached positions 50 to 150 feet below sea level in 1942. Since reduction of pumpage at Sparrows Point, water levels there have risen 50 to 100 feet, and in most districts today water levels are within 75 to 90 feet of the land surface. In the past seven years there has been little change in water levels in wells. Closely spaced wells have drawn down the water level excessively at some points, and a more widespread distribution of pumping would result in higher pumping levels and lower pumping costs.

Few wells in the Baltimore area are now pumping water entirely free from contamination, although most of the water pumped is only slightly contaminated. The Baltimore Harbor lies over part of the recharge area for the deeper artesian aquifer, and pumpage has induced infiltration of sea water until the water now pumped from wells in the harbor area is about as saline as that in the harbor. Continued pumping removes this salt water and prevents it from moving into well fields farther east which are not yet seriously contaminated. The shallow aquifer is also overlain by salt water along the Patapsco estuary, and this salt water has moved in as water levels declined below sea level, contaminating shallow wells in the eastern part of Baltimore.

Part of the serious contamination of the shallow aquifer is by sulfuric acid and copper sulfate from acid and metalrefining plants that have been situated in this area at one time or another during the past century. The acid water has corroded the casings of many wells, leaked through them into the deeper aquifer, and contaminated it locally. Many abandoned wells may be responsible for contamination of the deeper aquifer in this way. Some leaking wells have been repaired by cementing, but in some instances water from the shallow aquifer is pumped and wasted in order to prevent it leaking into wells and contaminating adjacent deep wells. 
In the South heavy pumping at several coastal cities has resulted in development of cones of depression which extend below sea level. At Savannah and Brunswick in Georgia, and Fernandina, Miami, and Tampa in Florida, the ground-water reservoir is in permeable limestone; at Pensacola, Fla., and Gulfport, Miss., water is yielded by permeable sand and gravel. Salt water has moved into the ground-water reservoirs at Miami (see page 195) and at Tampa and St. Petersburg. At Pensacola, too, increasing salt content has been noted at some wells, which was probably drawn in either from Pensacola Bay or Bayou Chico. At the other places there is as yet no evidence that saline waters are entering the fresh-water reservoir. However, wherever the cone of depression drops below sea level, there is some cause for fear that the reversed gradient may eventually induce inflow of saline water from the ocean.

Savannah, Ga. ${ }^{60}$ Pumpage of artesian water in Savannah increased from 38 million gallons a day in 1912 to 47 million gallons a day in 1945 and is probably of the order of 50 million gallons now. Prior to 1880 the piezometric surface was about 35 feet above sea level in Savannah, sufficient to yield water by artesian flow. Pumping, however, has lowered water levels as much as 100 feet, so that they are now more than 50 feet below sea level in some wells. The cone of depression formed by pumping extends more than 20 miles in all directions.

The source of this water is the highly permeable Ocala limestone, 750 feet thick and with its top 200 feet below sea level at Savannah. This limestone is recharged in outcrop areas 70 or more miles northwest of Savannah. Under natural conditions water is discharged into the Savannah River from this limestone about 40 miles northwest of Savannah. Tests have indicated that the Savannah cone of depression has already extended far enough so that pumping

6o Reference: Warren, M. A., Artesian Water in Southeastern Georgia, Georgia Geol. Survey Bull. 49, 1944, 140 pp. 
has begun to divert some water from that area of natural discharge.

However, there is a possibility that further growth of the cone of depression may cause saline water to move toward the well field. Artesian water in the formation is somewhat saline in an area 30 miles northeast of Savannah. The pressure gradient may even now favor movement of this salty water toward Savannah at a rate probably not more than a few hundred feet a year. Observations are being made periodically at wells along the line of approach, in order to detect increasing salinity in ample time for remedial action.

St. Petersburg and Tampa, Fla. ${ }^{61}$ The difficulties of obtaining fresh water in the vicinity of Tampa Bay are due to salt-water contamination rather than to an insufficiency of ground water, for the ground-water reservoir is a very permeable limestone and is well replenished by abundant rainfall. Pinellas County (in which St. Petersburg is situated) is a peninsula surrounded on three sides by salt water, and the fresh ground water on the peninsula is replenished only by local precipitation. About 11 million gallons a day is pumped from wells within the county. This pumpage has lowered the water table substantially in many places along the coast, with the result that salt water has moved in from the sea and contaminated the ground water in roughly onefourth of the county. Wells at St. Petersburg, near the tip of the peninsula, were contaminated by salt many years ago and were abandoned in 1930 when new wells were constructed 20 miles to the north, on the "mainland." These wells, 7 miles from Tampa Bay, yield 9 million gallons a day to St. Petersburg, and more water can be developed as the city's needs increase. Lake Tarpon, in the northern part 61 References: Cooper, H. H., Jr., N. D. Hoy, and A. O. Patterson, "The Water Situation in Florida," U.S. Geol. Survey, Unpublished rept., 1950, $13 \mathrm{pp}$.

Heath, R. C., and R. C. Smith, "Ground-water Conditions in Pinellas County, Florida," U.S. Geol. Survey rept., in preparation. 
of the county, is contaminated with salt water by subterranean movement from the sea.

Tampa once depended upon wells near Tampa Bay for its supply, but these wells became contaminated with sea water about 25 years ago. The city now obtains its water from the Hillsborough River, in an area where wells could provide an ample supply of water free of the "organic" color that appears intermittently in the river water. Wells north of Tampa Bay yield about 30 million gallons a day (not including the draft by St. Petersburg's wells), and large additional ground-water supplies can be developed if wells are located at sufficient distance from the bay.

Saline water has been drawn from adjacent brine-bearing formations into the overdeveloped portions of some groundwater reservoirs. In the Lake Charles industrial area and adjacent rice-growing areas of southwest Louisiana, salinity is greatest in the areas where water levels have been depressed most by pumping, and it appears that the pumping is drawing up water from underlying beds that carry saline waters (page 106). At Fort Pierce and at Stuart, Fla., salt water has moved upward through leaky wells into the developed artesian aquifer. In the Winter Garden area of Texas, the developed aquifer lies under the formation that carries the unusable waters.

Winter Garden, Tex. ${ }^{6:}$ The Winter Garden area includes several counties in southern Texas which have specialized in producing the vegetables that appear in northern cities during the winter. The use of water for irrigation has increased considerably in the past 10 years. In 1940 about 22,000 acres was irrigated from wells in Dimmit and Zavala Counties, and the use was about 1 acre-foot per acre. In 19.19, 50,000 acres was irrigated by pumping from wells, and since much of the land produced two crops in the year,

62 Reference: Texas Board of Water Engineers, Progress rept. for the period Sept. 1, 1946-Aug. 31, 1948, pp. 119-125, 1948. 
the pumpage may have reached 60,000 acre-feet. In addition some 17,000 acres is now irrigated by water from the Nueces River, and farther east perhaps 5,000 acres is irrigated from flowing wells in Atascosa County, which is now in about the same stage of development as Dimmit and Zavala Counties were 10 years ago.

The ground water comes from the Carrizo sand, which crops out in a belt 1 to 5 miles wide. Recharge is chiefly from precipitation on this outcrop, and records show that most of the recharge occurs in wet years, with very little in dry years. Southeast of the outcrop area the Carrizo is covered by the relatively impermeable Bigford formation, and the water is under artesian pressure.

In 1940 artesian pressures were slightly higher than in 1930, reflecting a slight decrease in irrigated acreage during the decade. Since 1911, however, artesian pressures in representative wells have dropped 20 to 100 feet, of which 5 to 40 feet occurred in the single year 1948. In the recharge area the water table is 5 to 8 feet lower than it was in 1941, having dropped 1 or 2 feet in 1948. The precipitation in 1948 was the least in 30 years, and the marked declines in water levels in the recharge area that year reflect the small amount of recharge and the increased pumpage for irrigation in a dry year.

The declines in artesian pressure are far greater than the decline of the water table in the recharge area and indicate that the rate of pumping from artesian wells is greater than the rate at which water can move through the sand from the recharge area. The water levels in the artesian wells will continue to drop until the draft and replenishment balance. The overlying Bigford formation contains salt water, which can contaminate the developed ground-water reservoir, and some contamination has already occurred at defective wells that permit leakage of salt water into the aquifer. There is likelihood of far greater contamination if part of the Carrizo sand in the artesian area is unwatered by pumping.

The water table in the recharge area is of critical impor- 
tance: if the decline of recent years is only temporary, due to deficient rainfall, there may be adequate replenishment on a long-term basis to sustain present draft; but if the water table in the recharge area is progressively lowered, it will be proof that present pumping is in excess of natural replenishment.

\section{Watercourse Problems}

The ground-water reservoirs in the alluvial valleys of perennial streams are considered as a separate group because of their intimate relationship to the water in the stream. The term "watercourse" is applied here to the stream and its associated ground-water reservoir. As defined by Hutchins, ${ }^{63}$ a watercourse is "a definite stream in a definite channel with a definite source or sources of supply, and includes the underflow. . . . The underflow is as much a part of the watercourse and as important from the standpoint of rights in the watercourse as is the surface flow; for if the waters within this subterranean area are withdrawn, the surface waters sink into the ground to take their place. The legal implications of this are widely recognized in court decisions. While the definitions of a surface watercourse seldom refer to associated waters in the ground, nevertheless the underflow is a physical part of the whole and the courts have held it to be a component part."

Various other definitions have been advanced for specific "watercourses," some far more restrictive than the above, and some that are hydrologically unsound. A watercourse, as discussed in the following pages, is considered to have the following essential features:

1. It is a geologic unit comprised of materials of varying textures and permeabilities but all deposited by the stream.

2. It is a hydrologic unit, in which both surface water and

${ }^{63}$ Hutchins, Wells, Selected Problems in the Law of Water Rights in the West, U.S. Dept. Agr. Misc. Publ. 418, pp. 7-8, 1942. 
ground water are moving toward the same general destination.

3. The watercourse may cross other ground-water reservoirs, in which case the other reservoir may discharge water into the ground-water reservoir and stream of the watercourse, or vice versa, depending upon the hydraulic gradient.

4. In the watercourse, impermeable beds provide no more than local isolation of surface water from ground water, or of the water in individual aquifers of the ground-water reservoir. In general there is intimate relationship to the extent that water traveling in the watercourse may be classed successively as ground water, surface water, and "diffused surface water" (see page 248).

Precipitation at any point along the watercourse may increase the quantity of water in the stream and also in the ground-water reservoir wherever conditions are farorable for recharge. Recharge to the ground-water reservoir is not limited to local precipitation but may come from the stream.

In segments of some watercourses, especially where precipitation is abundant, the water table of the ground-water reservoir is at all times higher than the stream level, and there is continuous movement of ground water into the stream. In other places, more likely to be in arid areas, conditions may be reversed, and water is always moving from the stream into the underlying ground-water reservoir. In many watercourses the stream gains from the ground-water reservoir when it is at low stage and recharges the ground-water reservoir at high stages. Recharge to the ground-water reservoir is commonly greatest during flood stages of the stream, not only because of the favorable hydraulic gradient, but because the finer and less permeable sediments are cleaned from the channel at that time. Also, the stream may overflow and saturate the materials of its flood plain for a considerable distance from the channel.

Characteristically in watercourses there is slow movement of water, called "underflow," through the ground-water res- 
ervoir. Underifow is the only method of movement in certain reaches of some streams, where the surface channel is dry. Because of the low velocity the quantity that moves by underflow in most watercourses is very small in comparison with the surface flow and is commonly neglected in statistics concerning outflow from drainage basins. On the other hand, the storage in the ground-water rescrvoir of a watercourse may be large and in many places is several times the quantity in the stream even at flood stages.

Development of the ground water in a watercourse is not limited by the replenishment from precipitation in a restricted area, as is the case in most ground-water reservoirs close to or beyond the limit of sustained perennial yield. Nor is it limited by the capabilities of an aquifer to transmit water long distances from points of replenishment, because the stream does the long-distance hauling. The basic factor limiting development at any point is the transmissivity of the rock materials between the stream and the well. Along the Nation's perennial streams are many places where the materials are permeable enough to yield large quantities of water to wells, and where the water withdrawn is replaced by infiltration from the stream. There are also many places where conditions are unfavorable for river infiltration. Assuming that hydrologic conditions are favorable for wells dependent upon river infiltration, such developments rely upon the stream as the ultimate source of water. They may be unsuccessful if the water of the stream is unsuitable for use or if it is unavailable for use because of prior downstream rights.

\section{WHERE THE SURFACE IVATER IS USABLE}

Practically every state has some wells which obtain water from its watercourses, and in some states there are large developments for public supply, irrigation, or industry. The most productive wells in the industrialized Northeast are along watercourses, and watercourses are the principal producers of ground water in New England, upstate New York, Pennsylvania, Ohio, West Virginia, Kentucky, and Indiana. 
Only a small part of the potential has been developed, and perhaps not even a dent has been made in the discharge of such large streams as the Ohio or the Susquehanna, or even the Connecticut or Wabash, by ground-water draft to date. Along large rivers such as these, the ultimate limit of ground-water development will doubtless be set not by the quantity of surface water available but by the limited areas available for occupancy along most watercourses, and the even more limited areas where water can be diverted from the stream through a permeable bed and to a well.

The watercourses of the Ohio River and its tributaries have been the sites of very large ground-water developments, notably at Pittsburgh and Louisville, and at Dayton, Cincinnati, Canton, Akron, Middletown, Hamilton, and Chillicothe in Ohio. The great potentialities of some watercourses for further development were put to good advantage during the war, and they furnished the huge water supplies required for such plants as the ordnance works at Clinton, Charlestown, and Terre Haute, Ind. However, some areas have been faced by serious ground-water problems, even by shortages of water in the midst of plenty.

Pittsburgh, $\mathrm{Pa} .{ }^{64}$ The Ohio River and its tributaries furnish the bulk of the water used in the Pittsburgh area, including as much as 125 million gallons a day for public use, and perhaps several billion gallons a day for industries. About 85 million gallons a day is pumped from wells, including about 70 million for industrial use. Ninety-five per cent of this water comes from sand and gravel in the water-

64 References: Adamson, J. H., J. B. Graham, and N. H. Klein, Groundwater Resources of the Valley-fill Deposits of Allegheny County, Pennsylvania, Pa. Topographic and Geologic Survey Bull. W-8, 1949.

Adamson, J. H., Ground Water in the Pittsburgh Area, Pa. Dept. of Internal Affairs Monthly Bull, vol. 17, no. 10, pp. 26-32, 1949.

Van Tuyl, D. W., Ground-water Resources of the Valley-fill Deposits in the Pittsburgh Area, Pennsylvania Journal of Science, in press. 
courses of the Ohio and Allegheny Rivers. Most of the wells are so situated that there is adequate replenishment by river infiltration or by local precipitation, and there are many excellent sites for development of additional supplies along both watercourses.

Serious troubles with ground-ivater supply have developed in two small areas in Pittsburgh. One of these is the "Golden Triangle" - the 0.4-square-mile area of flood plain at the junction of the Allegheny and Monongahela Rivers, which is Pittsburgh's downtown business district. More than 12 million gallons a day is pumped from 65 wells in the triangle each summer, more than half of which is for air conditioning. Water levels in some wells are lowered to within a few feet of the bedrock at the peak of the heaviest demand. Hydrologic studies have shown the reason for this condition. The ground-water reservoir under the triangle is not only of limited areal extent but also of limited thickness, generally less than 40 feet. Thus, it has only limited storage to meet the heavy draft for air conditioning. Recharge occurs chicfly from the streams which, except during high flow, are held at constant stage by a series of locks and dams. During periods of heaviest pumping the rate of withdrawal exceeds the rate of recharge, and water levels are lowered as much as 12 feet in unpumped wells and even more in production wells. The streams replenish this water during winter and spring.

The other problem area is near the upstream end of Neville Island, where large quantities of water are pumped for the north boroughs and for several large industries. Here, too, seasonal draft appears to be in excess of immediate replenishment, and much of the water is pumped temporarily from storage.

The problems of these areas result from the increasing demand for ground water and from development in ignorance of the capabilities for replenishment of the water taken from the ground-water reservoir. It is likely that the watercourses in the Pittsburgh area can yield far more 
ground water than is presently pumped, with full replenishment from the streams. Hydrologic data are needed to show the most promising areas for additional development and also the most economical corrective measures for the conditions that have developed in the heavily pumped areas.

Louisville, $K y .{ }^{65}$ Here the wartime shortage of ground water was acute. Some wells dropped far below the yield required of them, and it was obrious that pumpage of 63 million gallons a day took water from the well fields faster than it could be replaced by precipitation and the Ohio River. The industries dependent upon ground water took prompt action to prevent further depletion of the well fields, by reducing pumpage to 40 million gallons a day (conservation and reuse of water helped) and recharging the wells during the following winter with water pumped from the Ohio River by the city of Louisville. Since the war, pumpage has dropped to 30 million gallons a day; the water table is rising slowly in the industrial area but still dropping about 2 feet a year in the downtown area because of pumping for air conditioning. Since the war, too, hydrologic studies have shown that more than 250 million gallons a day can be developed by wells along a 7-mile reach of the Ohio River northeast of Louisville, and about 50 million gallons a day can be developed southwest of the city. To develop this water by infiltration, the wells must be spaced scientifically along the riverbank, not clustered to conform to the density of population or industry.

Parkersburg, W.Va ${ }^{66}$ This city has also been troubled by 65 References: Guyton, W. F., Depleted Wells at Louisville Recharged with City Waters, Water Works Eng., vol. 98, pp. 18-20, 1945.

Rorabaugh, M. I., "Ground-water Resources of the Northeast Part of the Louisville Area, Kentucky," Louisville Water Co., Mimeo, rept., July 1948, 77 pp.

66 References: Jeffords, R. M., Ground-water Conditions along the Ohio Valley at Parkersburg, West Virginia, W. Va. Geol. Survey Bull. 10, 1945, 57 pp.

Coffield, C. C., Horizontal Type Well Increases Ground-water Yield, Water Works Eng., vol. 100, no. 7, pp. 346-349, 1947. 
decreasing yield of wells since its first well was drilled in 1926 , but here the problem has been one of reduction of inflow to the well casings because of incrustation. There never has been any lack of adequate replenishment from the nearby Ohio River, and wells of different design are capable of a sustained production of more than 9 million gallons a day.

Des Moines, Iowa ${ }^{67}$ The public water supply for the city of Des Moines has for 80 years been derived from ground water in the watercourse of the Raccoon River. Currently more than 20 million gallons a day is pumped to serve a population of about 190,000; this is twice as much as was pumped in 1922, and four times the demand in 1910, when the population was about 80,000 . Since 1910 the city has practiced artificial recharge of the ground-water reservoir from which it takes its supply and thus is one of the real pioneers in controlling storage of water underground.

The ground-water reservoir of the Raccoon River Valley is in gravel and coarse sand about 20 feet thick, overlain by several feet of permeable soil. The city obtains its water from an infiltration gallery paralleling the river and about 3 miles long, which can lower the water table a maximum of 6 feet below the low-water level of the river. Studies have shown that as much as 90 per cent of the water produced by the gallery may be derived by infiltration from the bed of the river, and the rest is from downward percolation of local precipitation. The rate of river infiltration is substantially reduced when the river bed is covered with silt.

As early as 1910 the city was troubled by insufficient water supply during extended rainless periods when the river was

67 References: Burdick, C. B., Basic Principles of Ground Water Collection, Proc. Am. Water Works Assoc., p. 257, 1913.

Maffitt, D. L., Artificial Flooding Builds up Ground-water Yield, Water Works Eng., vol. 96, no. 22, pp. 1230-1232, 1943.

Board of Water Works Trustees, Description of Des Moines Water Works System (1945), and Annual Report for 1949. 
at low stage, and particularly when the river bed was covered with silt that impeded infiltration. To increase the underground storage in those periods, water was pumped from the river to flood the meadows in the vicinity of the gallery. By now the city has recharge basins totaling 65 acres which permit infiltration up to a million gallons a day into the ground. In recent years more than a third of the water pumped by the city has come from artificial recharge.

Peoria, $I l l .{ }^{68}$ About 85 million gallons a day is pumped from wells along a 15-mile reach of the Illinois River watercourse between Peoria and Pekin, Ill., of which perhaps 75 million gallons a day is for inclustrial and commercial use. Water is pumped from gravel deposits approaching a hundred feet in thickness. In 1945, water levels were receding at an average rate of 2 feet a year, and it was computed that the pumpage exceeded replenishment by 7 or 8 million gallons a day. Since then pumpage has been reduced somewhat by conservation measures, and the water levels in recent years have declined less than a foot a year. In downtown Peoria where the saturated part of the aquifer is relatively thin, there is not sufficient inflow of water at present to maintain present uses, and a dozen industrial and commercial users have already had difficulty in securing the water they need.

Hydrologic data indicate that the Illinois River is far less

68 References: "Control of Ground Water," Illinois Legislative Council, Publication 88, pp. 7-8, 1948.

Suter, Max, Apparent Changes in Water Storage During Floods at Peoria, Illinois, Trans. Am. Geophys. Union, vol. 28, pp. 425-437, 1947.

Larson, T. E., Geologic Correlation and Hydrologic Interpretation of Water Analyses, Ill. State Water Survey Circ. 27, 1949, 8 pp.

Horberg, Leland, "Ground Water and Geology of the Peoria Region, Illinois," Ill. State Geol. Survey, Unpublished rept., 1946.

Ground Water in the Peoria Region, Ill. State Water Survey Bull. 39 , in press. 
satisfactory as a source of ground-water recharge than the streams in many another of the nation's watercourses. Hydrologic interpretation of water analyses has confirmed this conclusion and shown that only about a third of the water pumped from wells is replaced by river infiltration. Of the 37 million gallons a day pumped in the Peoria and East Peoria well fields, only about 14 per cent was concluded to be of river origin, and most of that came from the small tributary, Farm Creek. On the other hand, about 75 per cent of the 11 million gallons a day pumped from the Pekin well field is evidently replaced from the river. The Pekin field, however, is below the dam on the Illinois River which stabilizes Peoria Lake by maintaining a minimum pool stage 440 feet above sea level. The silt which has accumulated in this lake to an average depth of 10 feet may well impede recharge near Peoria. In the past 17 years the greatest decline of water levels in several observation wells occurred during the three years after the dam was placed in operation. Recharge to the ground-water reservoir apparently occurs only when the river rises well above the pool stage created by the dam.

The Illinois Water Survey has had favorable results in experiments to recharge the ground-water reservoir by pumping river water into large filter beds. In addition, buried glacial valleys with large volumes of permeable gravel have been located northwest of Peoria and about 20 miles east of Peoria. These ground-rater reservoirs constitute potential additional sources of water.

This listing of problems encountered in developing ground water along some watercourses does not give a fair picture of the potentialities of such sources for additional supply in many places. One should also cite Dayton, Ohio, where wells pump about 90 million gallons a day and receive full replenishment from the Miami and Mad Rivers. Or the East St. Louis-Alton, Ill., industrial area where 85 million gallons a day are pumped: in an area of about 2 square miles the water table 
has been lowered about 10 feet below the minimum stage of the Mississippi River by this pumping, but elsewhere the water table still slopes toward the river, and it is evident that wells have not begun to induce infiltration from the river.

Ground-water reservoirs along watercourses have been suggested as potential sources of additional water at Indianapolis and South Bend, Ind., where water levels in some wells had dropped sufficiently to cause alarm. The marked success of large developments in scores of localities indicates that watercourses are very promising potential sources of additional water.

South Bend, Ind. ${ }^{69}$ The city of South Bend has been dependent on ground water for municipal supply since about 1886. Municipal pumpage was less than 2 million gallons a day prior to 1900 , reached $4 \frac{1}{2}$ million gallons by 1915 , and in 1944 was more than 14 million gallons a day. The pumpage from prirate wells has probably followed a similar trend. In 1944 it was about 16 million gallons a day, of which nearly half was for the important machine and metal-working industry. Of the total 30 million gallons a day pumped in the South Bend area, more than a third was taken from wells in the downtown business district. The rate of pumping dipped slightly during reconversion after World War II but has probably climbed above 30 million gallons a day in recent years.

The meager available records indicate no significant changes of water levels in wells prior to 1915. Since that year there has been a lowering of water levels in most wells, of the order of 8 to $20 \mathrm{feet}$, or an average rate somewhat less than half a foot a year. The decline probably correlates with the increasing rate of withdrawal, with some variations resulting from changes in rate of recharge from precipitation during the 35 -year period. The decline marks the develop-

69 Reference: Klaer, F. H., Jr., and R. W. Stallman, Ground-water Resources of St. Joseph County, Indiana, Ind. Div. of Water Res. Bull. 3, 1948, 82 pp. 
ment of a regional cone of depression necessary to divert water to the pumping wells. Rough computations indicate that about 10 to 15 per cent of all water pumped in the last 50 years has been taken from storage.

The ground-water reservoir tapped by wells in South Bend is recharged chiefly by local precipitation, that is, precipitation in South Bend and an adjacent area that may extend as much as 5 miles from the city limits. Under natural conditions the ground water in this area moved to the St. Joseph River. In the eastern part of the city where wells have not materially changed those conditions, ground water is still being discharged to the river at an estimated rate of 16 million gallons a day. In the downtown business district and at certain other wells close to the St. Joseph River, pumping has lowered the water levels below minimum river level, and it is possible that significant replenishment occurs by river infiltration. However, the South Bend Dam may have caused accumulation of silt sufficient to reduce the rate of such infiltration, analogous to the condition at Peoria. Hydrologic studies are needed to determine where conditions may be favorable for river infiltration, with the likelihood that additional ground water could be developed from wells close to the river for South Bend's future needs. Away from the river the largest undeveloped ground-water supplies appear to be in the eastern part of the city, where there is wastage to the river.

Canton, Ohio, ${ }^{70}$ depends upon watercourses of small magnitude. Most of the 67 million gallons a day pumped from wells comes from ground-water reservoirs in buried glacial valleys, some of which are no longer occupied by a perennial stream. For additional supplies to meet in-

70 References: Schaefer, E. J., G. W. White, and D. W. Van Tuyl, "The Ground-water Resources of the Glacial Deposits in the Vicinity of Canton, Ohio," Ohio Water Res. Board Bull. 3, June 1946.

Kazmann, R. G., The Utilization of Induced Stream Infiltration and Natural Aquifer Storage at Canton, Ohio, Econ. Geol., vol. 44, pp. 514-524, 1949. 
creasing municipal requirements, Canton in 1947 turned to the small west branch of Nimishillen Creek, where gravel strata near the surface are readily recharged by the creek but have relatively small storage capacity. Under this gravel and separated from it by clay is another gravel stratum, with large storage capacity but slow natural recharge. The city uses both aquifers for its water supply: the upper aquifer yields as much as 18 million gallons a day to the lower gravel through recharge wells constructed for the express purpose, and 10 million gallons a day or more can be pumped perennially from the deeper reservoir.

WHERE THE SURFACE WATER IS UNSUITABLE FOR USE

The technique of inducing infiltration from a river is generally to locate wells close to the riverbank, where the distance traveled by water in rock materials is minimum, and the hydraulic gradient encourages rapid transmission. Of course if the river carries brackish or otherwise unsuitable water, wells close to the river will draw in that water. Wells at Wilmington, N.C., Fort Myers, Fla., and New Haven and Bridgeport, Conn., have pumped water that has infiltrated from the tidal portions of nearby streams. In several of these places the problem has been solved by developing wells at greater distances from the streams. The problems of brackish-water infiltration from a river are typified by the experiences of Mobile, Ala.

Mobile, Ala. ${ }^{71}$ This city obtains its municipal water supply from small tributaries of the Mobile River, and ground water is used chiefly for air conditioning. In the downtown district as much as 2 million gallons a day has been pumped from wells 25 to 90 feet deep in the alluvium along the watercourse of the Mobile River. Under natural conditions this alluvium receives sufficient replenishment by downward percolation of precipitation that the water table is generally higher than the river level, and ground water moves toward the stream. At flood stages, however, the river water moves 71 Reference: Peterson, C. G. B., Ground-water Investigation in the Mobile Area, Alabama, Geol. Survey Ala. Bull. 58, 1947, 32 pp. 
into the alluvium, and because the stream is tidal and brackish, ground water has always been somewhat saline within about 800 feet of the stream channel. The pumping for air conditioning has lowered the water table below river level and has induced river infiltration. In downtown Mobile, saline water has been detected as much as 2,300 feet from the channel, and the salinity has increased in one well from 950 parts per million of chloride in $19+2$ to 2,200 parts per million in 1945 .

A deep artesian reservoir, 800 feet below the surface, yields water by artesian flow with a temperature about 6 degrees higher than the water from the shallow aquifer. There is relatively little draft from this aquifer, and artesian pressures have not declined in recent years. Wherever the salinity in the shallow aquifer has made the water unsuitable for air conditioning, there are the alternatives of drilling other shallow wells farther from the river, or using the warmer water from the deeper aquifer or from the Mobile public supply.

About 2 miles north of Mobile some 13 million gallons a day is pumped from shallow and deep wells for manufacture of paper. Salt-water encroachment there has been a problem only in the shallow wells nearest the river.

Rivers may be contaminated at many places other than in the coastal areas where ocean water moves upstream. Streams constitute a common means of disposal for the mineral matter dissolved by water in their drainage basins. Those draining areas of saline or gypsiferous rocks are likely to carry much dissolved mineral matter, as for instance the Cimarron River and Salt Fork of the Arkansas in Oklahoma, where both the streams and ground-water reservoirs of the watercourse carry saline water. As another example, El Paso, Tex., along the watercourse of the Rio Grande, could obtain an ample supply of water from the ground-water reservoir recharged from the river. Both the stream water and shallow ground water are highly mineralized, however, owing in part to return flows 
from irrigation in New Mexico, and are far inferior to the water in another ground-water reservoir available to the city. El Paso does use some mineralized Rio Grande water after treatment, mixing it with water from the other reservoir, which does not yicld enough potable water to meet the city's expanding needs (see page 57 ).

The dumping of brines from oil fields into streams has rendered the streams temporarily unfit for use, but appears to have wreaked more permanent damage on the ground-water reservoirs of the watercourse. Thus Ponca City, Okla., was forced to abandon wells in the Arkansas River Valley because of increasing saltiness of the water infiltrated from the Arkansas River, contaminated by brines from the Eldorado oil field in Kansas. Salt-water damage to ground water in the alluvium of the North Canadian River downstream from Oklahoma City has been caused largely by disposal of oil-well brines. Several of the tom along this reach of the river once obtained their water supplies from wells in the alluvium, but practically every town has been forced to obtain surface-water supplies from tributaries not affected by oil fields, and the alluvium of the North Ganadian River has been abandoned as a source of fresh-water supplies. Six of these towns collected $\$ 421,000$ as damages by pollution to their former water supplies but were forced to spend more than 2 million dollars for new supplies. ${ }^{72}$

The contamination of a ground-water reservoir by polluted stream water is a major problem in the Philadelphia-Camden area, where about 110 million gallons a day is pumped from wells, chiclly for industrial use. The watercourse of the Delaware River here crosses the recharge area of a major groundwater reservoir which extends southeastward into New Jersey. Some of the recharge to that formation doubtless comes from local precipitation but most is probably derived from the Delaware and Schuylkill Rivers. The quality of the ground water is deteriorating, as shown by the increasing hardness, iron, and sulfate in solution. Industrial wastes, garbage; and sewage

72 Schoff, S. L., "Salt-water Intrusion in Oklahoma," U.S. Geol. Survey, Mimeo, rept., May 1941, 5 pp. 
along the streams, coal culm and sludge on the river bottom, doubtless are largely responsible for this deterioration. ${ }^{i 3}$

Contaminated stream water is not necessarily an indication that all the water in a watercourse is unsuitable for use. As an example, the Red River in Louisiana carries water too hard for most purposes, and the ground water in the alluvium is of similar composition. But the ground water has a more uniform temperature than the surface water, which makes it suitable for use in cooling or air conditioning. Use of this water has been recommended at Shreveport, where concentrated draft on another ground-water reservoir has caused a progressive decline of water levels, with the result that many wells have been abandoned.

Data from wells adjacent to the highly polluted Ohio River indicate that coliform bacteria are not transmitted into them from the river. Whether there is wholesale destruction of pathogenic organisms in the silt and sludge of the river bottom, or during the filtration through permeable materials, is not known. Scientific data are still far too meager to define the limits of safety from pathogenic organisms where a well induces infiltration from a polluted stream (see page 20?).

\section{WHERE THE SURFACE WATER IS USED DOTNNSTREAM}

The water in most western streams is not a surplus that will flow unused to the ocean, but is on its way to some downstream user. Pumpage from wells that induces infiltration from such a stream becomes an infringement on the previously established rights of the downstream users. However, many of these watercourses discharge large quantities of water to the atmosphere by evaporation or transpiration that is of no benefit to mankind. Salvaging this wasted water requires methods of ground-water development that will divert water only from the area of consumptive waste, without depleting the quantity of water available for downstream uses.

In some western valley's ground water has been developed

${ }^{73}$ Graham, J. B., Ground-water Problems in the Philadelphia Area, Econ. Geol., vol. 45, pp. 210-221, 1950. 
along watercourses in disregard of the intimate relation between the ground-water reservoir and the flow of the stream. The Gila River Basin in Arizona and the Rio Grande Basin in New Mexico are examples.

Safford and Duncan-Virden Valleys, Ariz. and N. Mex. ${ }^{74}$ (see also page 84). Since Coolidge Dam was constructed in 1928, there never has been enough water to fill the reservoir, and the lands irrigated from that reservoir have experienced perennial shortages of surface water. Upstream from Coolidge Reservoir the Gila flows through Safford Valley, and closer to the headwaters, Duncan Valley in Arizona and Virden Valley in New Mexico (the latter two being parts of a single large valley). The ground-water reservoirs of both Safford and Duncan-Virden Valleys are part of the Gila watercourse and are recharged chiefly by irrigation, using water from the stream. In Duncan-Virden Valley ground-water pumpage increased from 1,000 acre-feet in 1941 to 27,000 in 1948, and in Safford Valley about 110,000 acre-feet was pumped in 1948. This pumpage must inevitably cause some depletion in the flow of the Gila River below Safford Valley. On the other hand, it has been estimated that evapotranspiration loss in Duncan-Virden Valley exceeds 10,000 acre-fect and is of the order of 50,000 acre-feet in Safford Valley. Wherever pumpage from wells has depressed the water table sufficiently to reduce these natural losses, some water has been salvaged for beneficial purposes.

Middle Rio Grande Valley, N. Mex. ${ }^{75}$ Albuquerque and some other towns pump water from wells in the alluvium of the Rio Grande Valley for municipal supplies, but for irrigation the valley depends almost entirely upon water

74 Reference: 'Turner, S. F., et al., "Water Resources of Safford and DuncanVirden Valleys, Arizona and New Mexico," U.S. Geol. Survey, Mimeo. rept., 1941.

75 Reference: "Regional Planning. Part IV. The Rio Grande Joint Investigation in the Upper Rio Grande," National Resources Committee, vol. 1, 1938, 566 pp. 
diverted from the river. The flood plain of the middle Rio Grande, between White Rock Canyon and San Marcial in New Mexico, averages 2 miles in width and comprises 120 , 000 acres, of which about half is irrigated by surface water.

Ground water occurs at shallow depths everywhere under the flood plain. In 1936 the water table was less than 8 feet deep under 90 per cent of the irrigated area of the flood plain, and less than 5 feet deep under 40 per cent of the area -high enough to be detrimental to the growing of many crops. The high water table is evidently due chiefly to irrigation. Many drainage structures have been constructed in the valley; these have been largely instrumental in lowering the water table as much as 3 feet in the 10 years preceding 1937. During 1938, however, the water table rose nearly 0.2 foot under the entire flood plain, probably due to increased rainfall and floods, and to clogging of some drains.

Another important reason for the rise in water table is the raising of the bed of the Rio Grande by sedimentation. Between 1927 and 1936 the river bed at San Marcial rose 5.4 feet, because of lessened gradient following construction of Elephant Butte Reservoir downstream, depletion of stream flow by diversions for irrigation, and increased rate of erosion in the tributary area.

Some of the water in the ground-water reservoir is discharged into drains and returns to the river for further use. Underflow from the valley is of small magnitude, perhaps 750 acre-feet a year. Most of the discharge is to the atmosphere, for the water table is high enough to permit large quantities to be discharged by transpiration and evaporation. According to the report by the National Resources Committee, there was 100,000 acres of water-loving vegetation in the valley above Elephant Butte Dam in 1936, which consumed more than 380,000 acre-feet of water a year. Some of the native vegetation used about twice as much water per acre as the irrigated crops in the valley. Since 1936 both 
the area and density of water-loving vegetation have in creased, and salt cedar (one of the worst of water wastrels) has infested progressively increasing areas near the river above San Marcial. The consumptive waste by vegetation is considered to be largely responsible for New Mexico's inability to meet the terms of its compact with Texas in the past eight years.

In 1948 about 15,000 acre-feet of water was pumped for municipal, irrigation, and industrial use. Records show that there has been little lowering of water levels, and pumping has probably not reduced significantly the flood-plain evapotranspiration losses. Unless the pumped water is salvaged from that waste, it is inevitable that the flow of the river must be depleted.

In the Elephant Butte district below the Middle Rio Grande Valley, pumping from irrigation wells began in 1948. The conclusions of a study recently completed are: "The ground-water and surface-water supplies are interdependent, and ground water pumped in the Rincon and Mesilla Valleys does not represent an additional supply or new source of water but rather a change in method, time, and place of diversion of the supplies already utilized." i6

The Nebraska Supreme Court has construed the state water code as restricting the use of water to lands within the watersheds of major drainage basins whence the water originated. Nebraska also has, in the Platte River Valley, an exceptional example of a watercourse from which ground water escapes, flows under a topographic divide, and enters a different watershed. There a decision as to the respective rights of users in separate watersheds to water that has already been used for irrigation requires a thorough knowledge of the movement of ground water and its relation to surface water.

76 Conover, C. S., "Ground-water Conditions in the Rincon and Mesilla Valleys and Adjacent Areas in New Mexico," U.S. Geol. Survey, Typed rept., October 1950, 316 pp. 
Platte River Valley, Nebr. ${ }^{77}$ The watercourse of the Platte River is a major source of water for Nebraska and is one of the best examples in the country of multiple use of water. The waters of the South Platte in Colorado and of the North Platte in Wyoming and Nebraska have already been used extensively for irrigation before they join in the west-central part of the state to form the Platte River. For more than a hundred miles downstream from this junction, water is repeatedly diverted from the stream, used for irrigation, and returned to the stream (except for the quantities lost by evapotranspiration). Increasing concentration of mineral salts results from this multiple use, but fortunately the river as it flows east traverses areas of progressively increasing rainfall, and waters contributed to the watercourse in the eastern part of the state serve to dilute the water moving down the valley from the west. Maintenance of a satisfactory salt balance is recognized as an important consideration in the planning for maximum utilization of the water in Platte River Valley.

In long stretches of the valley movement of ground water is toward the river, the channel of the Platte being low enough to act as a drain for the ground-water reservoir of the watercourse. In other stretches of the valley the movement of ground water is either parallel to the river or away from it. Ground water moves away from the river especially during periods when the river is at high stage, and this is borne out by recorded stream-flow losses and by detailed contours of the water table in several areas. Recharge to the ground-water reservoir is chiefly from precipitation on the valley floor and adjacent areas, supplemented by influent seepage of the river and principal tributary streams and by the seepage and return flow's from irrigation canals and irrigated lands.

There are about 5,500 irrigation wells in the 2,500 square 77 Reference: Waite, H. A., et al., Progress Report on the Geology and Ground-water Hydrology of the Lower Platte River Valley, Nebraska, U.S. Geol. Survey Circ. 20, 211 pp., 1949. 
miles of the Platte River Valley, and annual pumpage is estimated to be of the order of 350,000 acre-feet. Some wells near the channel pump water replenished by infiltration from the stream. Others pump water replenished by precipitation, but the pumpage nevertheless draws water that would otherwise move toward the stream and contribute to its flow. For many wells the natural supplies have been augmented by the downward percolation of irrigation water that was diverted from the stream.

Water-table contours for 1929 suggest that ground water left the watercourse between Kearney and Grand Island and moved south-eastward torard the drainage basin of the Blue River or the Republican River. Maps based on data collected in October $1948^{78}$ shows that water losses from the main supply canal and from Johnson Reservoir of the Central Nebraska Public Power and Irrigation District, together with seepage losses from water applied to agricultural lands in the district's Tri-County area, have since 1929 created a definite ground-water divide beneath the upland area south of the valley so that there is now less possibility of escape of ground water from the valley. However, only a fraction of the water percolating downward from the irrigated areas on the upland south of the valley returns to the Platte watercourse. The rest, on the south side of the groundwater divide, escapes from the Platte drainage basin. Seepage losses from the main supply canal and from Johnson Reservoir are estimated to be of the order of 190,000 acrefeet a year, but the amount of ground water that leaves the watercourse is unknown.

Ground-water storage in the watercourse is sufficient to cushion the effects of alternating dry and wet climatic cycles. During the dry 1930's, pumping draft was greater than replenishment, and water levels declined in almost all parts

78 Part of a report based on cooperative ground-water investigations by the U.S. Geological Survey and the Conservation and Survey Division of the University of Nebraska, in preparation for publication in the near future by the Conservation and Survey Division. 
of the valley. In the following decade replenishment was greater than draft, and ground-rater storage by 1948 was about as great as in 1930. There are small areas of concentrated draft from wells, however, where water levels are now more than 5 feet lower than in 1930.

The ground water in a watercourse may have a significant bearing upon administration of compacts that allocate usage of water of interstate streams. As an example, the flow of the Arkansas River from Colorado into Kansas is modified substantially by ground-water development. Although the Arkansas River Compact of 1949 does not mention ground water, its effective operation depends upon an adequate knowledge of the ground-water hydrology of the watercourse in Colorado.

Arkansas River Valley, Colo. and Kans. ${ }^{79}$ The Arkansas River is outstanding in the extent to which the natural flow has been modified by development of both surface water and ground water. The major water-producing area is the headwaters area in the Rocky Mountains, and the plains of eastern Colorado and western Kansas contribute relatively small quantities to the river. Under present conditions the river does not "hold its own" after it leaves the Rockies. Generally, the flow is least in reaches near Garden City, Kans., where the channel may be dry for weeks at a time in the summer. The average annual flow at Garden City is only about one-third of the runoff from the mountainous headwater area, although the drainage basin is about eight times as large. Downstream from Garden City the inflow from tributaries and from ground water is so great that the 79 References: Waite, H. A., Geology and Ground-water Resources of Ford County, Kansas, Kans. Geol. Survey Bull. 43, 1942, 250 pp. McLaughlin, T. G., Geology and Ground-water Resources of Hamilton and Kearney Counties, Kansas, Kans. Geol. Survey Bull. 49, 1943, 220 pp.

Latta, B. F., Geology and Ground-water Resources of Finney and Gray Counties, Kansas, Kans. Geol. Survey Bull. 55, 1944, $272 \mathrm{pp}$.

Frye, J. C., and V. C. Fishel, "Ground Water in Southwestern Kansas," Kansas Geol. Survey, 1949, 24 pp. 
annual runoff at the Kansas-Oklahoma state line is more than five times as great as that at Garden City.

Diversions from the river for irrigation in eastern Colorado and western Kansas account for most of the decrease in stream flow in those areas. Pumping from wells for irrigation in the Arkansas River Valley has also caused a significant reduction in the flow of the river. Many of the wells are used to supplement surface supplies, and are pumped chiefly in dry years. Total annual pumpage doubtless fluctuates considerably and may approach 150,000 acre-feet in some years. Most of the reduction in stream flow occurs in Colorado, but detailed ground-water studies have not been made of that part of the Arkansas Valley, and the effect of ground-water development upon stream flow cannot be assessed quantitatively.

In Kansas ground-water studies have shown that heavy pumping of ground water for irrigation, especially between Syracuse and Garden City, has stopped the seepage to the stream which characterized that reach under virgin conditions and has depleted the stream to the extent that the channel often goes dry, particularly in the summer. Prior to 1925 the ground-water inflow to the stream in this reach was frequently more than enough to offset the diversions through canals and wells. In the past quarter century stream losses have been recorded every year; in most years the losses have been substantially greater than the canal diversions and were undoubtedly caused in part by pumping from wells. Infiltration of river flow into the ground-water reservoir has not only replenished the water pumped for irrigation but has been of considerable value in dissipating floods. In recent years many floods that passed Syracuse have been largely absorbed by the partly depleted ground-rvater reservoir near Garden City. Only the largest floods continued as far downstream as Larned, and these had greatly reduced crests. Doubtless the pumping from the several hundred irrigation wells in the Arkansas Valley in Colorado has had similar effects upon the flow of the river. 
The Arkansas River Compact of 1919 has ended a 50-year interstate controversy by providing an acceptable method of apportioning the river flow between water users in Colorado and Kansas. Basically this compact provides protection to water users in western Kansas. Colorado users have the natural advantage of "high-ority," which would give them all the water if there were no legal restraint, and in central Kansas the precipitation and stream flow are great enough to make it unnecessary to rely upon water originating in Colorado.

The compact provides for a division of the natural river flow into the John Martin reservoir (near Lamar, Col.) and of the water stored in the 420,000-acre-foot conservation pool of that reservoir: 60 per cent is allocated to Colorado users and 40 per cent to Kansas users. In years when stream flow exceeds the demands of water users in both states, the John Martin reservoir can carry over some storage to the following year; in 1948 the holdover storage was of the order of 150,000 acre-fect. Otherwise the compact provides for division of the natural flow of the river, with short-term maximums and minimums leveled off as far as possible by the reservoir, and with no allowance or accumulation of credits or debits for or against either state.

Each year there are extended periods when the entire flow of the river is used for irrigation above Garden City, Kans., and because of return flow from irrigated lands, some water is used more than once. But in most years substantial quantities of water flow past Garden City at some season. In the past decade the annual runoff at Garden City has ranged from 1,340 acre-feet in 1940 to 1,220,000 acre-feet in 19+2, and since the John Martin reservoir was completed, the runoff at Garden City has ranged from 39,400 to 306,500 acrefeet.

Although in the present stage of development the quantity of water utilized must vary considerably from year to year, the water users are not entirely at the mercy of the 
vagaries of natural precipitation and stream flow. The John Martin reservoir can give more uniform flow from year to year than the natural stream, through holdover storage. The ground-water reservoir along the watercourse also cushions the effects of alternate excess and deficiency of stream flow. Many wells are pumped only when water is needed to supplement inadequate stream supplies, and most wells are pumped more heavily in drought than in wet periods. That water is pumped from underground storage. At some wells the pumped water may be replaced quickly by river infiltration; at others the replacement may be delayed for several months or even several years, until the river is at higher stage or until local precipitation is more abundant. In the absence of ground-water studies in the area, it is not possible to say where ground-water development might cause direct depletion of stream flow and where such development might depend instead upon recharge during periods of surplus supplies; but it is likely that in many places the ground-rvater reservoir could be manipulated like the John Martin reservoir, filling during flood stages and drawn upon in time of need.

By analogy with the Kansas part of the Arkansas Valley, where ground-water conditions are known, it is likely that pumping of ground water is partly responsible for the depletion in flow of the river as it flows across eastern Colorado. Wells divert water from the underground portion of the watercourse just as canals divert water from the visible supplies in that watercourse. However, the diversions from the ground-water reservoir may or may not cause an immediate depletion in stream flow, for the depletion may be delayed until the stream is at flood stage.

The Arkansas River compact is not intended to discourage further development of the water resources, and the water that spills past Garden City in most years can be a basis for additional development of both surface and ground water. The compact specifies, however, that such develop- 
ments must not cause any material depletion in usable quantity or availability for use, which would doubtless apply especially to periods when all the stream flow is needed to satisfy established rights. It will be necessary to increase our knowledge of the hydrology of the Arkansas watercourse in Colorado substantially (particularly of the ground water) if each future development is to meet these requirements. 


\section{GROUND-WATER PROBLEMS RESULTING FROM LAND OCGUPANCY}

Most of the serious ground-water problems facing the country today have resulted from our efforts to develop and use the water stored underground. If there is now less water underground than might be desirable, it is because this development and use has been unbalanced in some respects. But ground-water storage has also been modified significantly by our use of the land, or by our methods of disposing of wastes or protecting ourselves from floods or providing channels for navigation, or by other activities. Too often the effects of these activities upon ground water have been unintended and unforeseen; some have been beneficial, others detrimental either to the user of the land or to the user of ground water in the affected area.

The incidental effects of land occupancy upon ground-water storage are not nearly so well documented by scientific investigation as are the effects of ground-water development and use. In a few instances those changes have been so marked that hydrologic studies have been made in order to determine proper corrective measures. For the most part, however, the records as to changes in storage in undeveloped ground-water reservoirs are limited to the fragmentary accounts of untrained observers, and there has been no comprehensive analysis of those changes to determine their causes. 


\section{Effects of Agricultural Use of Land}

The major changes wrought by settlement of the country have been those resulting from derelopment and use of agricultural land. Almost everywhere, cultivation has been preceded by clearing of native forest, brush, or other cover, or by plowing of grasslands. Grazing, logging, and burning have also made significant changes in the vegetative cover.

This wholesale change of one of the renewable resourcesplant life-has of course changed the pattern of the animal life dependent upon it. It has also resulted in some major modifications in the resources of soil and water. The natural vegetative cover protected the soil from the eroding effects of running water or of wind, and its removal facilitated the removal of soil and the development of gullies. Some of the eroded material has been carried out to the oceans, but much of it has remained to create other problems, in sedimentladen stream channels and reservoirs. There have also been many historic changes in flow of springs and in the flood flows of streams, which some observers long ago described as due in part to changes in the vegetal cover. ${ }^{1}$ In recent years research in small watersheds widely distributed over the country has provided a quantitative relation between the rate of flood runoff and the type of vegetative cover. ${ }^{2}$

These rather appalling effects of man's use of the land are by no means universal. Throughout the country there is great diversity in all the factors that could have any bearing on the infiltration or overland flow of waters. The earth materials at the land surface in some places are so exceedingly permeable that water from precipitation is absorbed as fast as it reaches them; they may be devoid of vegetation because water drops out of reach before plants can use it. In other places dense

1 Marsh, G. P., "The Earth as Modified by Human Action," 2d ed., pp 203274, Scribner Armstrong and Co., New York, 1877.

2 Rates of Runoff for the Design of Conservation Structures, A Series of Reports Covering the Basic Land-resource Areas of the United States, U.S. Soil Conservation Service, Tech. Pubs, 60-69, July 1946-August 1948. 
and impermeable clays and bare rocks permit negligible infiltration of water into the ground. Some slopes are so steep that appreciable runoff may occur even though the surficial materials are moderately permeable; other areas so flat that water from precipitation may remain long enough to permit infiltration into relatively impermeable soils. Some regions are so arid that the soil is powder-dry at nearly all times, others so wet that the ground is saturated practically to the surface.

Enlightened programs of land management, watershed management, and soil-and-water conservation are devoted to the correction of the untoward effects of man's past unwise use of the land. These programs include a wide variety of operations to achieve a corresponding variety of results in specific localities. Grassed waterways and some channel modifications are designed to permit overland flow but to prevent soil removal. Strip cropping, contour plowing, and terracing are designed to slow up and deflect overland flow on sloping, cultivated terrain. Dense vegetative cover of forest, brush, or grass may prevent overland flow and soil loss; but in some places the soil is porous enough to permit subsurface storm flow, which reaches streams rapidly enough to be included in floods. The various practices that impede overland flow provide increased time for infiltration, and where these are combined with practices that increase the rate of infiltration, a greater amount of moisture is bound to find its way into the soil. Ground-water reservoirs will be replenished if infiltration continues after the soil has reached field capacity, but not until then.

A change in the vegetative cover or of tillage practices is likely also to cause a change in the rate at which water is returned to the atmosphere by transpiration and evaporation. All plants use water and thus deplete the supply of soil moisture. In some areas of semiarid climate a common waterconservation practice is to allow fields to lie fallow-bare of vegetation-in alternate years; the basis is that the reduction in transpiration results in an increase of soil moisture available for crops in the intervening years. 
Because of the draft upon water resources by vegetation, practices that are effective in preventing despoliation of the soil resources do not necessarily increase the net water supplies available for man's use. The effects of various agricultural practices upon the soil and soil water are treated below, and the effects of those practices upon ground water are considered subsequently.

\section{EFFECTS UPON INFILTRATION AND OVERLAND FLOW}

The disposal of water that falls on the land surface as precipitation-whether by infiltration into the ground or by flow over the surface-is of major significance to the agriculturist. Overland runoff can carry away his precious soil, cut his fields by gullying, and then create problems for downstream users of water in streams and reservoirs. Water infiltrated into the ground, on the other hand, may remain in the soil and be used by his crops. The alternative methods of disposal are thus the alternatives of benefit or detriment, of conservation or waste.

The soils and rock materials that form the land surface vary tremendously from place to place in their capabilities for absorbing water. The surficial materials in some areas are so exceedingly permeable that overland runoff rarely occurs, and in other areas they are so impermeable that there is negligible infiltration of water into the ground. By far the greater part of the land surface is formed by materials moderately to slightly permeable.

The high natural infiltration capacities of gravels, sands, boulders, and some other rock materials have generally not been modified by man's use of the land. Although these extremely permeable materials cover only a small proportion of the area of the country, there are some drainage basins in which a high percentage of the precipitation is absorbed into the ground and the flow in streams is derived chiefly from ground water discharged at relatively constant rates. The Metolius River in Oregon, draining permeable basalts, and the Loup River in Nebraska, draining the Sand Hills, are out- 
standing examples. Other streams that are well regulated by ground-water reservoir control are the Peconic River in New York, Maurice River in New Jersey, Mad River in Ohio, Tippecanoe River in Indiana, Muskegon River in Michigan, Fox River in Wisconsin, South Fork of Provo River in Utah, and Warm Creek in California. Some very productive groundwater reservoirs are located within these and other similar drainage basins. The recharge areas of many other groundwater reservoirs, occupying only small parts of drainage basins, are composed of very permeable materials, such as sand and gravel, which have high capacity for infiltration. Orerland runoff is unlikely in these materials, and permeability is high enough to permit rapid infiltration and ground-water recharge. For agricultural use it might be desirable to reduce the permeability in order to hold water within reach of plant roots.

Man has done little to change the infiltration capacities of the least permeable land surfaces. These are formed by the dense bare rocks of mountainous regions, by impermeable shales, or by clays such as those in the rice-growing areas. Infiltration rates are so low that a large proportion of the precipitation is disposed of by surface runoff and eraporation. Streams draining these impermeable areas are characteristically "flashy" and are well typified by the Bayou Nezipique in Louisiana, where storms of moderate intensity may cause sharp increases in stream discharge. In many areas infiltration is impeded by clay pan, hardpan, or caliche at shallow depth below the surface, and the impermeability is thus a product of soil derelopment. Where the underlying rock materials are more permeable than these surficial layers, that is, where impermeable soil covers a ground-water reservoir, the recharge to the ground-water reservoir is impeded by the soil zone. Increasing the permeability of very tight materials is highly desirable but difficult of achievement.

The surficial materials in most of the country are moderately to slightly permeable. The great soil groups of agri- 
cultural importance are included here. ${ }^{3}$ Detailed studies of stream-flow characteristics have shown marked differences in absorptive and retentive characteristics of drainage areas which are superficially similar in topography and geology and in which most of the surficial materials are rather poorly permeable. ${ }^{4}$

The great majority of the experimental watersheds of Federal and state agricultural agencies are surfaced by materials in this broad middle bracket of permeabilities, that is, fine sand, sandy loam, and soils of finer texture. Studies of individual plots and small watersheds have shown that the infiltration rate-and therefore the surface runoff-varies markedly from time to time depending upon the condition of the watershed-which includes such factors as soil water and ice, tillage practices, and type and density of vegetative cover.

Detailed research into the effects of cultivation upon the disposal of rainfall has generally been limited to small plots or to watersheds having an areal extent up to several hundred acres. Infiltration rates may vary greatly from place to place even within a small area, reflecting the variations of texture of the soil. As an example, 50 determinations of infiltration rates within 100 acres all give different rates, and the greatest

3 Free, G. R., G. M. Browning, and G. W. Musgrave, Relative Infiltration and Related Physical Characteristics of Certain Soils, U.S. Dept. Agr. Tech. Bull. 729, 1940, 51 pp. As stated on pp. 3 and 4: "The 68 sites included in this study were selected by soils specialists as representative of important contrasting soils. . . . These 68 sites represent 39 soil series and 6 of the great soil groups, gray-brown Podzolic soils, red and yellow soils, soils of the northern prairies, northern Chernozan soils, soils of the southern prairies, and brown soils. They also represent the nine following groups of parent material: glacial accumulations (calcareous), glacial accumulations (slightly calcareous or noncalcareous), Great Plains material, marine deposits (marl and chalk), marine deposits (sands, clays, and limestones), wind-laid deposits (loess), residual accumulations, crystalline rocks, and sandstones and shales. These soils include 16 that are properly classified as sandy clays and sandy loams, or sands, and 52 of finer texture, including loams, silt loams, clay loams, silty clay loams, and clays.

4 Troxell, H. C., and H. M. Stafford, Natural Water Losses in Mountain Drainage Areas of Southern California, Trans. Am. Geophys. Union, vol. 30. pp. $752-758,1949$. 
was more than 100 times the least. ${ }^{5}$ For this reason the quantitative studies of areas at least several acres in extent are likely to give more reliable estimates of average infiltration.

The effects of agricultural land use upon rates of infiltration have been shown both by comparison of cultivated or bare areas with adjacent areas having native cover, and by alternating cultivation and noncultivated cover on a single experimental area. It has been found that the effect of cover upon infiltration capacity may be more important than soil type: ${ }^{6}$ this is true particularly of the broad group of soils in which clay is an important constituent. Some experiments have shown a greater degree of variation in infiltration capacity resulting from surface conditions on a single soil, than is found on different soils having the same surface conditions. ${ }^{7}$ In studies of three plots of the same type of soil, the infiltration capacity of a cultirated plot was found to be only one-fourth of a plot with native grass cover, and less than that of a bare, uncultivated plot. $^{8}$ The program of the experiment stations of the U.S. Soil Conservation Service has included studies of infiltration and runoff from representative soils in all parts of the country. Results of these studies were summarized in $1940,{ }^{\circ}$ and further analyses of data have been presented in a series of recent technical papers. ${ }^{10}$

The effects of grassland and forests upon the disposal of the water falling as precipitation have been determined by the same techniques as for cultivated or bare land, and indeed very commonly in the same experiments, so that comparisons are readily available. The most widely recognized benefits of

5 Rowe, P. B., "The Construction, Operation, and Use of the North Fork Infiltrometer," Flood Control Coordinating Comm. Misc. Pub. 1, Calif. Forest and Range Exp. Sta., 1940, 64 pp.

6 Lewis, M. R., and W. L. Powers, Soil Sci. Soc. Am. Proc., pp. 334-339, 1938.

7 Duley, R. I., and L. L. Kelly, Nebr. Agr. Exp. Sta. Research Bull. 112, 1939.

8 Muckel, D. C., Some Factors Affecting the Rate of Percolation on Waterspreading Areas, Trans. Am. Geophys. Union, vol. 17, pp. 471-474, 1936.

9 Free, G. R., G. M. Browning, and G. W. Musgrave, op. cit.

10 Rates of Runoff for the Designs of Conservation Structures, U.S. Soil Conservation Services, Tech. Pubs. 60-69, 1946-1948. 
forest or grass cover on the land are the minimizing of overland flow from intense storms and the protection of the soil from erosion when overland flow does occur. A major factor in these benefits is the increased infiltration under such cover; surficial forest litter is exceedingly permeable, and as far down as roots can penetrate, the plant material will increase the permeability of soils, particularly those which are mineralogically of dense texture.

Proof that by our use of the land we can change the proportion of water that will infiltrate into the ground is no longer limited to the results of research in experimental areas. The nationwide program of soil conservation, embraced by more and more of the public in the past 15 years, has done much to reverse the trend of progressive erosion and deterioration of soil. The return of once-cultivated land to forest or grass cover, contour farming, strip cropping, terracing, and other practices have been successful in reducing runoff and getting more water into the soil, as shown by reports from farmers and others in many sections of the country.

On the other hand, the several factors controlling the infiltration-runoff proportion vary so greatly over the nation that it is difficult to make generalizations as to the effect of specific land practices upon the water resources. As an example, it is common practice in some parts of California to burn the brush cover of foothill slopes used for stock range. An effort has been made to determine the effect of this practice upon the water resources, based on analysis of field studies, experimental research, and expert opinions. The conclusions from this analysis are as follows: ${ }^{11}$

Evidence is presented indicating that removal of vegetative cover will increase both runoff and erosion by decreasing the infiltration capacity of the soil and through some changes in soil structure. There is also the contrary evidence that burning has

11 Adams, Frank, P. A. Ewing, and M. R. Huberty, "Hydrologic Aspects of Burning Brush and Woodland Grass Ranges in California," Calif. Div. Forestry rept., p. 78, January 1947. 
not decreased infiltration capacity or increased runoff and crosion. Soils, topography, rainfall intensity, and extent of vegetative recovery-all factors affecting runoff and erosion-vary so widely that no single rule can be applied. We conclude that on the basis of our present information burning can be neither supported nor condemned for all conditions and situations in the California brush and woodland-grass ranges or watersheds.

Our available experimental data do not provide a basis for a conclusion that burning of the ranges in northern California is adverse to water conservation. Even where the data show increased surface runoff immediately after burning, the amount of the increase in the northern California experiments is but a small percentage of the total rainfall and of the total water supply if applied to a large area. The soil moisture studies in the northern California experiments showed more moisture at the end of the summer in the burned plots than in the covered plots, since the soil moisture of all plots was raised to field capacity by the winter rains and transpiration was greater on the covered plots. The percentage of total precipitation represented by the surface runoff from the North Fork plots in central California was greater than in the northern California experiments. But.whether this increased surface runoff, if applied to a substantial portion of a watershed, would reduce usable runoff is not clear. We believe that a much more thorough study of the relation of brush burning in northern and central California to water conservation is needed before fully accepting the assumption that it is a vital factor. We of course realize that some people-especially foresters and soil conservationists-associate range burning in northern and central California with floods, but we have not dealt with this question and know of no experimental or other precise data linking range burning in northern and central California with floods, from which a conclusion can be drawn. We draw no conclusion as to the relation of burning to water conservation and floods in southern California, since the areas from which we have presented important data are not used for grazing and hence are not directly involved in the range-burning problem. Extensive chaparral and woodland-grass areas in Riverside and San Diego Counties are used for grazing, but no definite conclusions are yet justified from the recently installed experiments in Riverside County, nor do the observational data from the Moreno Reservoir silta- 
tion study seem to us to warrant conclusions regarding burning and water conservation there.

\section{EFFECTS UPON STORAGE IN GROUND-WATER RESERVOIRS}

Where recent gullies have been cut deeply enough to intersect the water table, the water table has been lowered as effectively as it would have been by a drainage canal of similar depth. ${ }^{12}$ Otherwise, ground-water reservoirs are affected by land use only to the extent that the rate of downward percolation from the soil is modified. Since only the water that is surplus to the needs of the soil percolates downward, its quantity is determined not alone by the amount of infiltration but also by the return to the atmosphere through evaporation and transpiration. The comparative return of water to the atmosphere before and after the land-use change is an important factor in determining the effect of that change upon groundwater reservoirs.

The findings as to the effects upon ground-water reservoirs of the agricultural use of the land in the past century or two are based in part on interpretation of the meager historical records but chiefly on experimental research in the past two decades.

\section{HISTORIC RECORDS}

The popular notion is that there has been a general and progressive decline of "water tables" (using the term to include the artesian-pressure surfaces of artesian aquifers) throughout the nation. It is true that in many localities water levels in wells are now considerably lower than in bygone days and that these localities are widely distributed throughout the nation. There are enough records to show also that the condition is not universal, for the "water tables" in many areas are higher today than in past decades and in some instances higher than at any time in history. In most of the country the 12 Bryan, Kirk, Change in Plant Associations by Change in Ground-water Levels, Ecology, vol. 9, pp. 474-478, 1928. 
data are too meager to show the long-term trends in water levels.

Most of the detailed records of water-level changes in wells cover only the last decade or two, and records begun as early as 1920 are considered long records. So far as known, there are fewer than 50 wells where data have been collected for half a century or longer. Very few records have been analyzed in sufficient detail to deduce the quantities of water represented in the changes of storage indicated by the water-level fluctuations. For most areas not enough is known of the hydrologic characteristics to permit such analysis.

The causes of water-level fluctuations are many. In order to discriminate the effects of changes in land use, it is necessary to know the effects of these other factors. One very significant factor is pumping. As shown in the preceding chapter, lowering of water levels is characteristic of wells in areas of ground-water development and is the physical expression of the process of diverting water to wells and from its path of natural movement. Wherever water levels are affected by pumping, any effects of changed land use are likely to be hidden by these more pronounced fluctuations. Most of the long records of water-level fluctuations have been obtained from wells in areas of pumping.

Climatic factors are also responsible for significant changes in ground-water storage. Water levels fluctuate in daily, seasonal, and climatic patterns. In many wells water levels decline during dry years and rise during years when precipitation is above normal. Several hydrologic studies suggest there may have been trends in climate during the past century that would tend to reduce the replenishment to ground-water reservoirs and thus cause some decline of water levels in wells. In the absence of century-long records of ground-water levels, it is necessary to rely on records of other phases of the hydrologic cycle, from which changes in ground-rvater storage may be inferred on the basis of known interrelationships of water in all phases of the cycle. 
The long-term precipitation records from about 125 towns have been used in studies of rainfall-runoff relationships prior to $1935 . .^{13}$ These studies conclude that there was a severe drought of wide extent between 1830 and 1850, followed by a general upward trend over most of the United States until about 1885; toward the end of that period the precipitation over much of the United States was greater than at any other time in the century. There followed a general decrease in precipitation, with widespread drought conditions toward the end of the century, except in the Pacific Northwest where precipitation reached an 80-year maximum about 1900. Beginning in 1915 , the trend orer the nation was upward, with maxima between 1910 and 1915 in the Rocky Mountains and Great Plains, and as late as 1925 in Texas. In each of these regions these maxima exceeded those of the 1880 's. The declining trend which culminated in the drought of the 1930's began as early as 1910 in some areas, and as late as 1925 in others. The minimum of the 1930 's was generally the lowest of record along both the Atlantic and Pacific Coasts but was not so low as the minimum of 1895 to 1905 in most of the interior. Since 1910 the trend has been generally upward except in the Southwest.

Regional temperatures also have an important bearing on ground-water replenishment, because as temperature increases the opportunity for evaporation and transpiration increases and less water is left for downward percolation. Records of temperature are generally about as long and as numerous as those of precipitation, and several studies of longterm trends have been published. ${ }^{14}$ In 70 widely distributed localities included in Hoyt's study, an increase in temperature has been quite general, and all but one of these localities recorded an increase since 1910 . Kincer shors that tempera-

13 Hoyt, W. G., et al., Rainfall and Runoff in the U.S., U.S. Geol. Survey Water-Supply Paper 772, pp. 20-110, 1936.

14 Kincer, J. B., Is Our Climate Changing? A Study of Long-term Precipitation Trends, Monthly Weather Rev., vol. 61, pp. 251-260, 1933; Our Changing Climate, Trans. Am. Geophys. Union, vol. 27, pp. 342-347, 1946.

Hoyt, IV. G., ibid. 
tures at the stations of longest record have been increasing progressively for 80 years or more, and drawing upon records from Canada, Europe, Asia, South America, and the East Indies, concludes that "the practically unanimous testimony of these graphs not only establishes the realness of these upward trends but shows that they are operative on an extensive geographical scale." In the years since 1940 there has been a slight downward trend at many localities, but it is not yet known whether this represents a reversal of the long-term trend. The argument that most records are obtained in cities where an upward temperature trend might result from man's occupancy has been anticipated by Kincer, and he has shown that the increase in temperature is as marked in Lynchburg, Va., Dale Enterprise, Va., and Easton, Md., as in the city of Baltimore.

Glaciers provide excellent evidence as to the balance between precipitation and evaporation: if the precipitation is heary enough or the temperature low enough to hold down the rate of evaporation, the glacier will advance. If precipitation is light and temperatures sufficiently high, the glacial front will recede. The long-term trends as shown by glacial advances and recessions result entirely from natural conditions and need not be adjusted for man's activity. Glaciers provide evidence as to long-term climatic trends in very few places in the United States, and except for the Nisqually Glacier on Mt. Rainier, the measurements of annual advances and recessions did not begin until 1930. Longer records are available in Europe, and data have been collected from areas distributed over the globe (Switzerland, Sweden, Iceland, Greenland, Alaska, Africa, South America, New Guinea, New Zealand, Antarctica). The data summarized by Matthes ${ }^{15}$ show that glacial recession has been general since the middle of the nineteenth century and that it is world-wide. The data, like those of temperature, suggest a rough synchronism in

15 Matthes, F. E., Glaciers, pp. 190-215 in "Hydrology," edited by O. E. Meinzer, McGraw-Hill Book Company, Inc., New York, 1942; Report of the Committee on Glaciers, Trans. Am. Geophys. Union, vol. 27, pp. 219-233, 1946. 
long-term climatic trends throughout the world; these trends in the last century would result in decreasing net water supplies, both of surface water and ground water.

Measurements by the U.S. Coast and Geodetic Survey show that there has been a gradual but progressive rise in sea level along the Atlantic, Gulf, and Pacific Coasts of the United States: slight in the first three decades of the century, and at an increased rate since $1930 .{ }^{16}$ It is not known to what extent these changes may be due to changes in the relative position of continental blocks and the ocean floors of the earth's crust. However, a decrease in the water held on the continents in streams, lakes, subsurface storage, or ice masses in arctic regions would result in a corresponding increase in the water of the oceans. The rise in sea level therefore is not in conflict with other hydrologic evidence that in the past century the trend has been toward decreasing net water supplies on the continents. Indeed, the pronounced rise in ocean level beginning about 1930 may reflect the widespread depletion of surface-water and ground-water supplies in the drought of the 1930 's. It is well known that during the glacial period when vast quantities of ice were stored on the continents, the sea level was several hundred feet lower than it is today.

The records of water-level fluctuations in wells, shorter by far than the records just cited of other phases of the hydrologic cycle, are not yet long enough to ascertain the effect of these suggested long-term climatic trends upon the storage in ground-water reservoirs. And because the possibility of significant long-term climatic effects cannot be eliminated, the effects of land-use practices cannot be ascertained satisfactorily from these water-level records, even in many areas where there has been little ground-water development. An example of the difficulty of ascertaining the causes of a long-term progressive decline in water supplies is afforded by Devils Lake, N.D., which has shriveled in area from 140 square miles to less than 5 square miles in the past 80 years.

16 Marmer, H. A., Sea Level Changes along the Coasts of the United States in Recent Years, Trans. Am. Geophys. Union, vol. 30, pp. 201-205, 1919. 
Devils Lake, N.D. ${ }^{17}$ The level of Devils Lake dropped progressively for more than 70 years. By 1940 the lake level was 37 feet lower than in 1867 , and the quantity of water stored in the lake had dwindled from about $1,500,000$ acrefeet to less than 20,000. At the low level of 1940, stumps were exposed in one of the separate pools ("Stump Lake"), indicating that the lake had reached even lower stages and probably dried up entirely, at some time since the Ice Age. Since 1940 the trend has been upward, and in the spring of 1950 the lake level was about 5 feet above the 1940 minimum. In May and June of 1950 the stream flow in a broad region that includes Devils Lake reached flood proportions, with disastrous results at Winnipeg, Canada. The inflow to the lake in this period was sufficient to raise the level more than 8 feet, to the highest point since 1925 .

In the past 10 years the water-level fluctuations in wells near the lake have corresponded moderately with those of the lake level. There may have been a progressive depletion of ground-water storage in the 70 years prior to 1940 , but there are no records to confirm this possibility.

The decline in lake levels has been attributed to the change of much of the drainage basin from grassland to cultivated land, but there is the question whether such a change would not instead have caused increased runoff to the lake; furthermore, there was only one farm in the 3,500square-mile drainage basin by 1880 , and the lake level had declined several feet before that year. The decline has also been explained as resulting from killing off of vast buffalo herds, which had been trampling and compacting the soil: with their demise, infiltration has improved and the inflow

17 References: Simpson, H. E., Physiography of the Devils Lake-Stump Lake Region of North Dakota, N. D. Geol. Survey, 6th Bienn. Rept., pp. 105-157, 1912; Geology and Ground-water Resources of North Dakota, U.S. Geol. Survey Water-supply Paper 598, pp. 190-191, 1929.

Swenson, H. A., "Chemical Character of Surface Waters in the Devils Lake Basin, North Dakota," U.S. Gcol. Survey, Mimeo. rept., $1950,46 \mathrm{pp}$. 
to the lake has decreased. Records from several places on the Great Plains indicate a downward trend in precipitation and an upward trend in temperature prior to 1940 , and these long-term climatic trends may have resulted in reduction of the net water supplies, both of surface and ground water. A basic hydrologic question still to be answered is how much of the inflow to the lake has been derived from ground water and how much from overland flow that has been unable to infiltrate into the ground.

It might be expected that changes in land use would have affected the flow of streams to the extent that those changes have resulted in modification of the amount of overland flow. However, most of the stream-flow records pertain to relatively large drainage basins. In general for these large drainage basins, as for the major ground-rvater reservoirs, the effects of land use are not clearly discernible in the available records, partly because the records are not long enough to cover the entire period of settlement and land development by the white man, partly because such effects are masked by the more pronounced effects of climate and of man's use of the water.

\section{EXPERIMENTAL RESEARCH}

Most of our knowledge concerning the effect of land-use practices upon ground-water reservoirs has been developed in research by the U.S. Department of Agriculture, and to an increasing degree in recent years, by the Tennessee Valley Authority and numerous state agencies and educational institutions. The research has been done with lysimeters and small plots, and also in small watersheds up to several thousand acres in extent. In these watersheds the studies have been directed toward isolating the various factors that control the relationships of precipitation, interception, infiltration, evaporation, transpiration, and soil moisture. In a few areas research has also included analysis of changes of water levels in wells, but in most the changes in ground-water storage have been derived as the difference between infiltration to the soil 
and return of water from the soil to the atmosphere. This return is calculated from determinations of evaporation from soil, use of water by plants, and interception of precipitation before it reaches the ground-these represent the water costs for each type of cover or each condition of soil.

The experimental areas are, generally speaking, in areas where the underlying rock materials have a low permeability, and clay is likely to be an important constituent in the soils. The experimental forests are typical of the national forests in that most of them are in mountainous areas with generally a thin mantle rock upon relatively impervious bedrock. The earth materials are predominantly of fine texture, and infiltration rates may vary markedly depending upon the vegetative cover and the organic material in the soil as well as the soil itself. In forested areas the surficial materials, down to a depth as far as roots can penetrate, commonly are far more permeable than the underlying subsoil or fragmental rock or bedrock. These soils have high infiltration capacities, and some of the water entering them may be discharged into streams within a matter of a few hours or days. This has been designated "subsurface storm flow." The shallow groundwater reservoir through which it moves may transmit large quantities of water in a short time but is generally limited in depth and therefore has only a small storage capacity.

The effectiveness of forests in preventing orerland flow and consequent erosion is illustrated in the Coweeta Experimental Forest, and by contrast in the Copper Basin some 50 miles to the west, where the forest cover has been removed.

Coweeta Experimental Forest, N.C. ${ }^{18}$ The setting of the Coweeta Experimental Forest provides an excellent op-

18 References: "Coweeta Experimental Forest Watershed Management Research," U.S. Forest Service, 1948, 40 pp.

Hursh, C. R., and E. F. Brater, Separating Storm Hydrographs from Small Drainage into Surface and Subsurface Flow, Trans. Am. Geophys. Union, vol. 22, pp. 863-870, 1941.

Hoover, M. D., Effect of Removal of Forest Vegetation upon 
portunity to study the operations of the hydrologic cycle and particularly the relation of forests to stream flow and ground-water storage. Located on the rugged east slope of the Nantahala Range in southwestern North Carolina, the headwaters of Coweeta Crcek (in the Tennessee River drainage basin) has been used as a hydrologic laboratory by the U.S. Forest Service since 1934. The experimental forest, 5,400 acres in extent, is underlain by gneiss and schist, which has been fractured to a considerable but unknown depth. The rocks have been deeply weathered, and the disintegrated rock is now covered by a clayey residual soil ordinarily 2 to 4 feet deep on ridges and slopes. In valleys and coves, and on benches, colluvium derived from these residual soils is commonly 4 to 8 feet thick and may be as much as 20 feet.

The average annual precipitation on the experimental forest ranges between 65 and 90 inches a year, depending largely on the elcration, which varies from 2,200 to 5,200 feet above sea level. The precipitation, nearly all rain, is uniformly distributed throughout the year, and at practically all times the soil moisture is adequate for the luxuriant vegetation. Except for the 3 to 5 per cent that falls directly in the stream channels, the water from precipitation infiltrates into the ground, and overland flow is practically nil. About 15 per cent of the annual precipitation is intercepted before it reaches the ground, 5 per cent is returned to the atmosphere from the soil by evaporation and 35 per cent by transpiration, and 45 per cent leaves the area as stream flow. With practically all the water moving beneath the surface to reach the streams, erosion in this mountainous area is limited to the soil creep down steep slopes, which is inevitable even with the best of vegetative cover-an effect of gravitational pull operating with the as-

Water Yields, Trans. Am. Geophys. Union, vol. 25, pp. 969977, 1944.

Dunford, E. G., and P. W. Fletcher, Effect of Removal of Streambank Vegetation upon Water Yields, Trans. Am. Geophys. Union, vol. 28, pp. 105-110, 1947. 
sistance of frost action, water lubrication, or other factors.

An important development of research at Coweeta has been the concept of "subsurface storm flow." In many observation wells, particularly where the water table is within 10 feet of the surface, the water levels rise sharply in response to infiltration from major storms. There is a correlative rise in stream discharge, closely resembling the pattern of storm flow in streams of other areas. Water must move rapidly underground to reach the stream so quickly. This movement is partly by turbulent flow, for trickling water can be heard underground after storms at Coweeta. Such rapid movement occurs especially in the porous soil with its litter, decayed root openings, animal tunnels, and the like. It is completely foreign to the capabilities of the mineral matter, for the gneiss and schist weather ultimately to a relatively impermeable clayey mass. Thus the vegetation has developed within the soil zone a permeability that permits detention storage for hours and even days. This detention storage reduces the crest of flood peaks in the streams and enables a greater portion of water to percolate into the less permeable rock materials below. The underlying less permeable material, rather than the surficial organic material, probably provides the retention storage that sustains the minimum flow of the streams over periods of several months.

The Coweeta Forest offers the bencfits of clear, perennial supplies at a formidable cost in water. Nore than 40 inches of water is returned annually to the atmosphere from the experimental area, a quantity that exceeds the total precipitation in most of the country. One phase of research has been directed toward increasing water yield with minimum sacrifice of the benefits of the permeable forest soil. On one small watershed all vegetation has been cut periodically for nine years (leaving the cuttings in place so as not to disturb the soil) and the annual yield of water to streams has been increased about 65 per cent; the yield during the hottest summer months has been doubled because of the reduction 
in interception and transpiration. Cutting of the broadleaved rhododendrons and laurels on another area has increased stream flow by about 5 per cent. Cutting of riparian vegetation along a stream has increased yield by about 20 per cent, but in the succeeding nine years, the new growth has taken a gradually increasing amount of water so that the yield of that basin is now just about the same as before the cutting.

In addition to these experiments, where every effort was made not to disturb the soil, some experimental areas are devoted to study of the effects of local logging, grazing, and cropping practices on the land. In these areas, there has been measurable loss of infiltration capacity and consequent increase in overland runoff and soil erosion.

Copper Basin, Tenn. ${ }^{19}$ This area in the southeast corner of Tennessee provides a notable contrast to the Coweeta Experimental Forest and shows the marked changes that can be made by land occupancy. Although the bedrock in the Copper Basin is not the same as at Corveeta, it has been similarly disintegrated by weathering and has formed a relatively impermeable clayey soil. The Copper Basin was originally covered by forest similar to that of the Coweeta area.

The copper deposits near Ducktown were discovered long ago and have been mined since 1851. Smelting changed the forest cover tremendously during the nineteenth century. Within an area of 7,000 acres around the smelters, all vegetation was destroyed by sulfur dioxide fumes, and over a larger area the trees not cut for fuel were damaged by the fumes. Severe erosion has resulted, especially in the central devastated area; the soil has been removed, and gullies as much as 25 feet deep have cut into the disintegrated bed19 References: Hursh, C. R., Local Climate in the Copper Basin of Tennessee as Modified by the Removal of Vegetation, U.S. Dept. Agr. Tech. Bull. 774, 1948, 38 pp.

Hixson, Fred, Conservation Plan in Copper Basin Starts Tree Growth on Barren Land, Chattanooga Times, April 17, 1950. 
rock. The sediment, washed into the Ocoee River, has completely filled the reservoir above Ocoee Dam No. 2 and slopped over into that at Dam No. 1 downstream. (These dams were constructed in 1912 and 1913.) Sediment from this watershed is now filling the reservoir formed by Ocoee Dam No. 3, constructed in 1913 by TVA upstream from the other two. The Copper Basin is by far the most serious erosion and sedimentation problem area in the entire Tennessee Valley and is the only one which TVA regards as an "engineering" problem (because of its effect on reservoir storage).

Many agencies have been interested in improving the condition of the Copper Basin. For several years a program of reforestation has been underway by the Tennessee Copper Company, in partnership with the TVA and U.S. Forest Service and interested state and county agencies. The program has already achieved some success, and the sponsors are hopeful of developing a managed forest that will eventually meet the company's lumber requirements, in addition to reducing erosion.

In the eyes of the thirsty West, the major economic value of the mountains is the water that comes from them in streams and canyons and produces both the surface-water and groundwater supplies of the intermontane valleys. The values of soils, forests, wildlife, recreation, and ground water in the mountains are subordinate and must be weighed in relation to the cost of their maintenance in terms of depletion of the water that the mountains provide for the inhabited and developed valley areas. However, the IVest is heavily dependent for sustained water supplies on storage in reservoirs along the streams. Because these reservoirs can be rendered useless by the sediment carried into them by the streams, a very important element in the conservation and utilization of the water resources is the holding of erosion and sedimentation to a minimum. A vegetative cover is one of the most effective means of holding loose earth materials on mountain slopes. 
A considerable fund of data has been developed as to the water cost of vegetative cover. Some of this cost is in precipitation that never reaches the ground but is intercepted by trees or other vegetation. Interception is reported to account for as much as 6 inches of water a year in some places. Experiments have shown that water cost may be reduced by cutting some of the timber, and thus reducing the interception of precipitation. ${ }^{20}$ Research in numerous experimental areas in the West has shown the comparative water costs of various types of vegetation.

Davis County Addition to Wasatch Forest, Utah. ${ }^{21}$ This experimental area on the steep west front of the Wasatch Range was established in 1934, after it had attracted nationwide attention to its devastating mud-rock flows in 1923 and 1930. Intense local rainstorms of the "cloudburst" type are common to the area in summer, and the slopes are so steep that soil or rock fragments are readily removed if not held down.

The mud-rock flows are a spectacular form of erosion and deposition. In a few hours following a single storm, thousands of tons of unsorted rock fragments ranging from clay to large blocks have been spewed out of the mouths of canyons and onto the Great Salt Lake valley plain. On the productive land of this plain these sediments have spread out over many acres, with a thickness as great as 12 feet in the most destructive floods. Some of the small streams on the Wasatch front have an average gradient of 50 per cent,

20 Wilm, H. G., and E. C. Dunford, Effect of Timber Cutting on Water Available for Stream Flow from a Lodgepole Pine Forest, U.S. Dept. Agr. Tech. Bull. 968, 1948, 43 pp.

21 References: Croft, A. R., Water Loss by Stream Surface Evaporation and Transpiration by Riparian Vegetation, Trans. Am. Geophys. Union, vol. 29, pp. 235-239, 1945.

Thomas, H. E., and W. B. Nelson, Ground Water in the East Shore Area, Utah, Utah State Engr., 26th Bienn. Rept., Pp. 109-119, 1918.

Croft, A. R., A Water Cost of Runoff Control, Jour. Soil and Water Cons., vol. 5, pp. 13-15, 1950. 
and in parts of the drainage basins the slopes approach 100 per cent. The mud-rock flows are water-lubricated, viscous masses of rock fragments that flow slowly down these canyons. Observations of small flows in recent years indicate that they are generated in bare areas that may be only a fraction of 1 per cent of the drainage basin.

Man has been credited with entire responsibility for creating conditions favorable for this destructive erosion, by removing the protective cover. Evidently the floods of 1923 and 1930 in Ricks Creek and Parrish Creek spewed materials directly onto glacial lake sediments and rere thus the first such occurrences since the waning stages of the glacial Lake Bonneville, thousands of years ago. Recent geologic studies have shown, however, that geologic, topographic, and climatic conditions were favorable for such flows long before man appeared on the scene. Before settlement, mud-rock flows occurred in Centerville Canyon, which has not produced a mud-rock flow in the past century. Wells in the valley area penetrate hundreds of feet of mudrock sediments, and the Wasatch Range has remnants of a deep, well-developed soil which was largely removed before Lake Bonneville reached its maximum level. Since the recession of that lake, the mountains have been raised as much as 75 feet with respect to the valley, along a fault that follows the base of the range throughout Davis County. The resulting increase in gradient has undoubtedly contributed to the severity of erosion and deposition in the 1923 and 1930 floods.

The first work in the experimental area was on the "sore" spots that could start mud-rock flows. Contour trenches were dug; check dams were constructed in incipient gullies; many other devices were placed to hold back overland flow. In subsequent years, programs of reseeding and reforestation have refined the control over surface runoff. The accomplishments have been great, and the valley residents have far greater assurance that their real-estate investments will not be wiped out. The steep 
slopes and intense rainstorms could not be modified, however, and it is perhaps unwise to guarantee immunity from destructive flows even now.

Some of the research on the Wasatch Range has been devoted to the water cost of various types of vegetative cover. It has been found, for instance, that grass takes a lesser toll than forest cover from the annual water supplies, because of the smaller depletion of soil moisture by its shallow roots. Stream-bank regetation takes large quantities of water from the small perennial streams in the canyons. Since mud-rock flows are commonly generated in higher areas and would tear out this stream-bank regetation as they pass, it serves little purpose in preventing erosion. The stream-bank vegetation may well become a casualty in the fight to obtain increased water supplies for man's use.

Most of the water supplies for valley communities comes from the melting of snow on the Wasatch Range in the spring. The effect of this melting shows up within a few hours in the canyon streams. Yet the melting of snowbanks in the forest does not result in overland flow but in infiltration. The rapid movement of that water to the streams suggests subsurface storms flow through permeable soils. Thus here, as at Coweeta, there is detention storage in the porous soil, but, judging by the small base flow in the canyon streams, relatively little retention in the underlying impermcable rock materials. Summer precipitation is almost all returned to the atmosphere and provides a negligible proportion of the net water supplies to the valley.

Sierra Ancha Experimental Forest, Ariz. ${ }^{22}$ This forest is in the rater-deficient area of the Salt River drainage basin. Vegetation could use all the annual precipitation if it were available at the right time. Scasonal distribution of precipitation, however, is such that about two-thirds falls during the winter dormant season. Nearly all the rest comes in cloud22 Reference: Rich, L. R., "Consumptive Use of Water by Forest and Range Vegetation," Am. Soc. Civil Engrs., April 1950 meeting. 
bursts in the hot summer months. The stream flow from the area, as from other areas in the Salt River drainage basin, comes chiefly from the winter precipitation. The contribution to stream flow from summer precipitation is limited to that from channel interception and overland runoff.

As summarized by Rich:

Vegetation or evaporation from bare soil could use more than all the summer precipitation in the Southwest, and consumptive use is dependent on total precipitation less the small amount of surface runoff that results from summer thunderstorms, and part of this is dissipated from dry stream channels by riparian vegetation and evaporation. Use during the winter period depends on growing conditions. The water that is surplus first satisfies the soil-moisture deficit and the balance is yielded as stream flow. Water use during the spring and early summer depends on the precipitation and the amount of moisture held in the soil from winter precipitation. Thus consumptive use by forest and range vegetation depends on the amount and distribution of the rainfall, the climate, topography, and the storage capacity of the soils of the watershed as well as the type of vegetation and the degree to which its use overlaps the period of water surplus. The principal way in which man can influence water yield is by sound management and use of vegetation cover, through proper livestock grazing, timber harvesting, etc., so that consumptive use overlaps and interferes least with the water-yielding period.

From a water-yield standpoint, the major question is not whether watersheds bare of vegetation would yield most water, but which type of vegetation interferes least with water yield and still controls sediment. In the Southwest grasses are dormant and do not use water during the winter water-yielding period. Use is largely confined to the summer period when there is no surplus water, and surface evaporation alone could consume all the precipitation. During the winter, high transpiration by half-shrubs, winter annuals, and evergreen shrubs, all characteristic of a deteriorated vegetation, tends to reduce water yield. Total annual use by grasses is slightly higher than eyaporation from bare ground but lower than losses from a deteriorated vegetation. The benefit of well developed and maintained plant 
cover in checking soil erosion and sedimentation of reservoirs outweighs by many times the value of the slight amount of water it uses.

Although there has been much research into the use of water by various types of cultivated and native vegetationgrasses, shrubs and trees, water-loving types and desert typeswe need to learn much more in order to resolve some of the apparent conflicts of existing data. For instance, we do not yet know in detail the variations in use by individual species of plants or the effects of changes in temperature or availability of moisture. Comparison of records of precipitation and stream flow in Tennessee Valley has indicated that annual erapotranspiration from that watershed is a relatively constant quantity. ${ }^{23}$ Thornthwaite has suggested that in a region where adequate moisture is available, the use of water by vegetation of any type will be dependent only upon the temperatures and hours of sunlight. ${ }^{24}$ On the other hand, researches in the W'est indicate a wide variation in rate of use by various species of plants. ${ }^{25}$

There are increasing indications that the use by a single species is not constant and that many types of regetation will use up all the water that is available to them in the growing season. ${ }^{26}$ In confirmation of this, studies of several groundwater reservirs recharged chiefly by precipitation have shown that there is little or no recharge during the growing season, even though rainfall is abundant. A very desirable product of research would be a plant that uses only small amounts of water even when there is plenty available, and yet provides an ample protective cover against erosion.

Another important question for research is to what extent the water used by vegetation depletes the net water supplies

23 Fry, Albert, Oral communication.

24 Thornthwaite, C. W., An Approach to a Rational Classification of Climate, Geog. Rev., vol. 38, pp. 55-94, 1948.

25 Young, A. A., and H. F. Blaney, Use of Water by Native Vegetation, Calif. Div. of Water Res. Bull. 50, 1942, 160 pp.

26 Musgrave, G. W., Oral communication. 
of each drainage basin. Particularly in the West, a large proportion of the water that falls as precipitation is returned to the atmosphere without ever reaching the streams or groundwater reservoirs. Vegetation sustained by this water might be removed or replanted without affecting these net water resources. The West has many barren areas, as well as forests, which make their contributions to streams chiefly as the snow melts and on which precipitation at other times may be dissipated without benefit to man.

A vegetative cover for prevention of erosion in these areas might draw in large part on water that would not in any case contribute to stream flow, just as the forests today subsist in part on water that would return to the atmosphere and not be available to the streams whether the forests were there or not. On the other hand, the nonbeneficial vegetation along streams and the native plants that draw on ground water for their supplics deplete the water resources that man might put to better use. And by depleting the soil moisture in recharge areas of ground-water reservoirs, other plants may reduce the quantity of water available for ground-water replenishment.

One of the major problems in the development of the river basins of the West is the tributary drainage basin that contributes large quantities of sediment but little water to the main stream. The Colorado and the Rio Grande have dozens of these tributary basins where nearly all the precipitation returns to the atmosphere except after intense storms, and then for a few days the main stream receives a veritable river of mud. Research is needed to show to what extent the water could be used within the tributary basin to prevent discharge of sediment. For some tributary basins the value of the total water contribution is negligible in comparison with the detriment of the sediment load to the fully developed river system.

ARTIFICIAL REPLENISIMENT OF GROUND-WATER RESERVOIRS

The reduction of overland flow by effective landmanagement practices generally increases the movement of water into the soil, and thus the conservation of soil and the 
conservation of soil water are very generally complementary programs. Any benefits to ground-water reservoirs have been largely incidental to these programs.

In artificial replenishment of ground-water reservoirs, many of the same techniques may be used, but the major objective is different. For the water user, the project is successful only if the replenishment to the ground-water reservoir is actually increased, and the fact of increased infiltration alone is not enough.

For artificial replenishment of a specific ground-water reservoir, it is necessary first to know that the water is being applied in an area where it can actually enter the reservoir. Special investigation may be required here, because the recharge areas of most ground-water reservoirs have not yet been delineated or mapped. A second major need is to be certain that the water applied for recharge actually gets into the reservoir and is not dissipated by evapotranspiration from the soil zone.

Most of the important ground-water reservoirs of the West are in the arid intermontane valleys and receive only a small proportion of their replenishment from precipitation on the valley floor. The bulk of the recharge comes from streams, and the greatest replenishment occurs when the stream flow is greatest. The quantity of water that continues on downstream is also greatest at that time, and in the streams that flow into the Pacific Occan, Great Salt Lake, or other interior basins, much of this flow is wasted.

Salvaging of this surplus water has been accomplished in many places by devices that hold the floodwater back and/or divert it into ground-water reservoirs by spreading it over permeable beds, thus causing artificial recharge. The success of water spreading is dependent upon the rate of infiltration that can be maintained, and many difficulties have developed because of sediment carried by the floodwater, or chemical constituents, or other hindrances to infiltration, even in sand and gravel or other highly permeable material. 
There are successful water-spreading projects in sevcral western states and in a few eastern states. Southern California has taken the lead in this field and has some of the oldest, largest, and most successful spreading projects. In the Upper Santa Ana Valley near San Bernardino, for example, artificial recharge was begun in 1912; the quantity of recharge has averaged about 15,000 acre-feet a year, but has ranged from none in several dry years to 68,000 acre-feet in 1922. Mitchelson and Muckel summarized numerous California studies in 1937, and pointed out that water spreading there has long since passed the experimental stage, and is a well-proved practice. $^{27}$

In several areas a vegetative cover has proved effective in maintaining a high rate of infiltration. Experiments in an offstream spreading basin along the San Gabriel River in California showed that infiltration in a grass-covered basin was 50 per cent greater than in an adjacent basin bare of vegetation. This increased infiltration was six to eight times the estimated water cost in transpiration from the vegetated basin..$^{28}$ From their studies of 15 water-spreading areas in southern California, Mitchelson and Muckel conclude that the consumptive use by vegetation is negligible in comparison with its beneficial effect on the percolation rate. Since the most effective use of underground storage may require putting water into the reservoirs, as well as taking it out, artificial recharge can be expected to become of progressively greater importance to water development, with vegetation in spreading areas playing a significant role.

Precipitation occurs on an "if, as, and when" basis that makes control more difficult than with stream water. It is a major factor in the recharge of some ground-water reservoirs, particularly in wet years, as shorwn, for example, in studies of

27 Mitchelson, A. T., and D. C. Muckel, Spreading Water for Storage Underground, U.S. Dept. Agr. Tech. Bull. 578, 1937, 80 pp.

28 Muckel, D. C., Some Factors Affecting the Rate of Percolation on Waterspreading Areas, Trans. Am. Geophys. Union, vol. 17, p. 472, 1936. 
the Chino Basin in southern California. ${ }^{28 a}$ There the average deep penetration of rainfall was found to be about $4 \frac{1}{2}$ inches a year in the period from 1927 to 1947. In the wettest year (1941) the penetration was about 16 inches, or about 19 per cent of the total deep penetration from rainfall in the period. About 60 per cent of the total penetration in the 20-year period occurred in the four wettest years.

In an area where it is intended to increase the proportion of precipitation that reaches a ground-water reservoir, there should be detailed data as to the precipitation cycle of the locality and its relation to the growing season, and as to the ground-water hydrology. Indiscriminate activity on lands, without this fundamental data, may get water into the ground in places where it can be of no value to the developed groundwater reservoirs and might even be harmful to the water resources. For example, many saline springs in the West serve only to contaminate the usable waters in streams, reservoirs, and wells. Operations in ignorance of the areal hydrology might increase the recharge to the aquifers that produce these springs, thus increasing the outflow of brine and aggrarating the contamination of usable supplies.

The need for discrimination in projects to increase groundwater replenishment is clearly seen by reference to Plate I, which shows that only half the area of the comtry is occupied by ground-water reservoirs capable of yielding moderate to large supplies of water. In the blank areas of that map, so far as known, fresh water occurs only in rock materials that are generally too impermeable to supply more than a few gallons a minute to wells. But many aquifers cannot be replenished at all places by downward percolation from the land surface. Wherever water occurs under artesian pressure, it is likely that the water enters the ground elservhere, at some point where artesian conditions do not exist. The actual area of the places where the nation's ground-water reservoirs are re-

28a Muckel, D. C., and V. S. Aronovici, "Progress Report on Rainfall and Irrigation Water Penetration and Consumptive Use in the Chino Basin, Santa Ana River Valley," U.S. Soil Cons. Service, Mimeo. rept., 1948, 96 pp. 
charged by precipitation is unknown, but, as a rough guess, it is hazarded that all the ground-ivater reservoirs capable of yielding large quantities of water to wells may be dependent for their replenishment upon infiltration in less than a quarter of the area of the nation.

\section{EFFEcts of Urban Use of LAND}

Urban areas cover a relatively small part of the total area of the country, but they include many of the areas where man has changed the land surface most profoundly. The topography has been modified by extensive cutting and filling, and natural drainage patterns have been revised materially. So far as the hydrologic cycle is concerned, some of the most significant changes have resulted from construction of buildings, pavements, and other impermeable surfaces upon the land. These have prevented infiltration into the ground in extensive areas. Precipitation upon them is carried elsewhere by drains to the sewer system or by snow-removal crews or other means. The water is generally not wanted immediately underground because of the damage it might do to utilities, or basements, or other subsurface structures.

The effects of urban development upon water supplies are quite varied. New York's Manhattan Island is an example of an area that contains no ground-water reservoir worthy of the name, and the storm sewers merely act as substitutes for the natural drains that carried the runoff when the island was worth $\$ 24$. Storm sewers of several cities empty into streams or other water bodies where the water is available for further use. In many cities the storm sewers are cut deeply enough to carry ground water as well as storm runoff from the city. In many residential areas, the water collected from roofs is discharged into the ground, so that infiltration may be equivalent to that which existed before the residential development.

Several cities are located on the recharge areas of important ground-water reservoirs, and of these there are some where 
the practice has been to pack the buildings so closely as to leave very little of the land surface uncovered. Brooklyn, south Philadelphia, and Baltimore are perhaps the best examples. About half of Brooklyn's 70 square miles is covered by buildings, pared streets and sidewalks, and other impermeable surfaces. Water from precipitation upon these areas is carried out to the shores of Long Island in storm sewers. It has been estimated that the replenishment to the ground-water reservoir in Brooklyn has been reduced by 30 to 40 million gallons a day by land occupancy (see page 125). This is equivalent to the current rate of pumping from wells in the borough.

Some residential communities that take their water supplies from wells deplete the ground-water reservoir considerably less than the total pumpage might indicate. In Pasadena, Calif., an intensive study of the Raymond Basin ${ }^{29}$ showed that 1 acre-foot of water pumped and used in sewered areas within the basin depletes the reservoir by 0.65 acre-foot, but 1 acrefoot used on unsewered areas depletes the reservoir by only 0.19 acre-foot. Pumping of about 28,000 acre-feet a year has not drawn on the reservoir as much as expected, partly because of the return flow after use. Nearly half the groundwater replenishment comes from infiltration of precipitation over the basin, a far greater proportion than in undeveloped desert areas. This high contribution is attributed to the fact that there is never any great deficiency in soil moisture because of the use of water on lawns and gardens, etc., throughout the growing season.

\section{IRRIGATION AND DRAINAGE}

Significant changes in ground-water storage have resulted both from activities involving the irrigation of crops in arid regions and drainage of swamps or lake beds. In many cases the changes of ground-water levels have created difficulties

29 Report of Referee, Pasadena v. Alhambra, Pasadena C-1323, Superior Court of Calif,, p. 188. For the complete reference to this case, see footnote 17 on page 60 of this book. 
for the landowners or their neighbors. But taking an optimistic long view, they all show that it is possible to manipulate ground-water levels and make considerable changes in the quantity of water stored underground by nature.

\section{RISING WATER TABLE IN IRRIGATED AREAS}

The use of surface water for irrigation has almost everywhere been accompanied by a rising of the water table due to downward percolation from the irrigated areas. Under natural conditions, ground water is at shallow depth in the low central portions of most western valleys and near the channels of through-flowing streams. In valleys where there is irrigation by surface water, the water table has risen under many of these lowlands because of lateral movement from higher irrigated lands. In the mountain valleys of Montana (see page 86) and several other states, thousands of acres of bottom land have been abandoned because of waterlogging, and the waterlogging still continues because of irrigation of lands at higher elevation. In Utah, where irrigation has been practiced for more than a century, many areas once irrigated have been abandoned because of high water table and increasing salinity of the soil due to evapotranspiration; most of the abandoned farms are in the lower parts of the intermontane valleys. The use of the Snake River for irrigation in southern Idaho has in some places increased ground-water storage and raised the water table until lands have become waterlogged; in other places it resulted in marked increase in discharge from springs (see page 89).

The effects of percolation from irrigation have been bene. ficial in many areas. In several valleys in Utah, irrigated lands are so high on the alluvial fans of the tributary streams that water has percolated into the recharge areas of artesian reservoirs, thus benefiting the users of ground water in those valleys. And just above the waterlogged areas in many Western valleys, the water table is at optimum depth for farming without application of water to the surface, for the crops depend upon "subirrigation." 


\section{LOWERED WATER TABLE IN DRAINED AREAS}

The total acreage of cultivated land has been increased materially by drainage of swampy areas and lakes. There are drainage projects in practically every state, but they are especially numerous in those states where the last glacial advance of the Ice Age left thousands of lakes, swamps, and undrained depressions. In Michigan about 14,000 square miles of land has been subjected to artificial drainage, accomplished by about 23,000 miles of open or tiled ditches. The regional water table has been lowered significantly in about one-third of this area, where 90 per cent of the drainage ditches are located.

In many places the drainage has not been as beneficial as anticipated. Some drains have made land suitable for plowing earlier in the spring but have also reduced the available water supplies for crops in the critical late-summer months. Commonly the effects of drainage have extended considerably beyond the troublesome swampy area, and the water table has been lowered to the disadvantage of the surrounding areas. Drainage of natural depressions has in many areas aggravated the flood capabilities of streams, by providing an outlet for surplus runoff that, prior to drainage, had been held within the area.

The history of the Everglades Drainage District in southeast Florida reveals drainage problems of greater variety than usually encountered in a single area.

The Everglades and Miami, Fla. ${ }^{30}$ The Everglades is favored with an ample supply of water on an annual basis, but the seasonal distribution of precipitation is not all that could be desired. Generally during the months from January to May water is required for irrigation of crops, and on

30 References: Jones, L. R., et al., Soils, Geology, and Water Control in the Everglades Region, Univ. Florida Agr. Exp. Sta. Bull. 442, p. $168,1948$.

Parker, G. G., et al., Water Resources of Southeast Florida, U.S. Geol. Survey Water Supply Paper, in preparation. 
the other hand the flat agricultural lands are inundated by floods at fairly frequent intervals, usually during the hurricane season. There is an obvious need for storage of water for dry-season usage, but unfortunately the ground-water reservoirs are not of much help. The rock materials near the surface have a very low permeability, and water from precipitation forms lakes and swamps. The limestones that lie at depths of 400 to 1,200 feet yield highly mineralized water. Lake Okeechobee, however, stores enough water to provide the bulk of the 110 million gallons a day used for irrigation, public consumption, and sugar refining in the Everglades area.

The soils of the Everglades are predominantly muck and peat, and in the past four decades major efforts have been made to drain a portion of the area for agricultural use, with partial success. The drainage has caused a subsidence of 3 to 6 feet in the organic soils, resulting in complications in the maintenance of drainage. It has also permitted destruction of the dried peat by oxidation and uncontrolled fires. Morcover, it appears that extensive and indiscriminate drainage has threatened the water supply for municipalities along the coast, by reducing the fresh-water head and permitting sea water to encroach into the aquifers. The largest cities along the coast east of the Everglades are Miami, Fort Lauderdale, and West Palm Beach. Drainage canals from the Everglades reach the coast near each of these cities.

The metropolitan Miami area currently uses about 80 million gallons of ground water a day, of which 50 million is for municipal use and the rest about equally divided between irrigation and industrial use. Owing to the lowering of water levels brought about principally by the Miami canal and other uncontrolled tidal canals, salt water has moved from Biscayne Bay into the principal aquifer. The tidal canals at times carry salty water inland for several miles. Saline water entered Miami's Hialeah well field (along the Miami Canal) in 1939. As Biscayne Bay receives the un- 
treated sewage of Miami, there is also a danger of bacterial pollution.

Dade County (which includes Miami) is engaged in a water-control program to prevent inflow of salt water through drainage canals and encroachment into the aquifers. Locks or other control structures are planned for all the major canals discharging into Biscayne Bay and will be designed to hold water on the upstream side during dry periods as high as drainage requirements will permit, and to have ample capacity for passing the flood flows during wet seasons.

The principal source of the water used by Miami and other coastal cities is the abundant precipitation upon the Atlantic coastal ridge, which infiltrates into very permeable aquifers. Most of this water is discharged unused into the ocean. The problems of salt-water encroachment are limited to those areas where the water table has been lowered to sea level by drainage or by concentrated pumping.

Drainage is a major problem in many mines, and in some places the cost of pumping water has become so great as to cause abandonment of some workings. On the other hand the water from some mines is of considerable value in several areas in the West, where it can be used for irrigation, public supply, or other purposes. For example, the waters from the Ontario Tunnel near Park City and the Elton Tunnel near Tooele, Utah, are used for irrigation. In the Iron River district of Michigan, investigations of the ground-water phenomena have been in progress for several years, with the expectation that the knowledge so gained will scrve to reduce the costs of mining caused by water in the mines. ${ }^{31}$

\section{REGULATION OF POSITION OF THE WATER TABLE}

It has been possible in many irrigated areas to solve the problems of waterlogging by drainage. In the earliest irriga-

31 Stuart, W. T., C. V. Theis, and G. M. Stanley, Ground-water Problems of the Iron River District, Michigan, Mich. Dept. Conserv., Geol. Survey Div. Tech. Rept. 2, 1948, 58 pp. 
tion projects the corrective measures were undertaken only after the need for them was shown by the loss of production from certain lands. As almost every project for irrigation by surface water is likely to create problems of rising water table eventually, the probable needs for drainage have become an essential part of preliminary project investigation and planning.

The magnitude of the requirements for drainage in irrigated western valleys is suggested by the conditions in San Joaquin Valley, Calif. (page 70), where by 1940 some 505,000 acres in a total irrigated area of 749,000 acres had been provided with drainage. ${ }^{32}$ The preferred type of drainage is by pumping from wells, because wells can be placed where drainage is needed and can lower the water table to greater depths than can be done by any other method. In the Turlock irrigation district, for instance, the increase of waterlogging and alkalinity reached alarming proportions early in the century, and open drains excavated about 1920 did not help much. Beginning in 1924, the district started to pump from wells for drainage. By 1943 about 155,000 acre-feet was pumped annually, of which 120,000 was used for irrigation elsewhere in the district. The drainage pumps are operated so as to maintain the water table at a fixed depth of about 6 feet. In some valleys the use of wells for drainage has provided water so valuable for irrigation that pumpage has been expanded for additional supplies and lowered the water table significantly.

In the very permeable soils of the west slope of San Luis Valley, Colo. (page 87), the farmers have found it possible to regulate the position of the water table by adjusting the water levels in ditches, which thus have become combination irrigation and drain ditches. Water reaches the crops by subirrigation and need not be distributed over the fields. By contrast, in Cache Valley, Utah, experiments have shown that waterlogging of the clayey soils in the lower parts of the valley is 32 Ewing, P. A., "Irrigation and Drainage in San Joaquin Valley, Calif.," U.S. Soil Cons. Service, Mimeo rept., p. 54, 1946. 
due in part to upward movement of water from an artesian reservoir. The water table could be lowered by pumping from the artesian strata, but this has not yet been attempted except on an experimental basis. In Imperial Valley, Calif., where there is a dearth of permeable sediments at any depth, drainage problems have resulted from irrigation of land by water from the Colorado River.

Cache Valley, Utah and Idaho. ${ }^{33}$ Cache Valley, in northern Utah and southeastern Idlaho, has ample water resources to sustain its current needs, and since the Bear River discharges an average of 750,000 acre-feet a year into Great Salt Lake, it is evident that there are possibilities of additional development of water in its drainage basin, which includes Cache Valley. Most of the water used for irrigation is diverted from streams, several of which drain limestone mountains and have a well-sustained flow throughout the irrigation season. Wells yield perhaps 20,000 acre-feet a year for irrigation, stock, and domestic use and waste, and nearly all of them are flowing wells. The withdrawal from wells is generally less than the average recharge, and shut-in artesian pressures are ordinarily highest in August, even though practically all wells are flowing at that time. It is likely that the ground-water reservoir now contains substantially more water than it did a century ago, because of irrigation in the valley.

The most serious water problems in Cache Valley are caused by too much water. Thousands of acres of land on the floor of the valley are waterlogged. The Utah Power and Light Company's Cutler Reservoir occupies 6,000 acres near the outlet of the valley and was once regarded as largely responsible for the high water table in a much larger area.

33 References: Peterson, W., Ground-water Supply in Cache Valley, Utah, Utah State Agr. Coll, Ext. Ser. N.S. 133, 19ł6, 102 pp.

Israclson, O. W., and W. W. McLaughlin. Drainage of Land Overlying an Artesian Ground-water Reservoir, Utah Agr. Exp. Sta. Bull. 242, 1932, 56 pp;; Bull. 259, 1935, 32 pp. 
Studies have shown, however, that the effect of the reservoir extends only a short distance beyond its boundaries. Other studies show that the real culprit is probably the artesian reservoir. Under most of the valley floor, water in sand and gravel strata is confined under artesian pressure by a layer of clay less than 50 feet thick in many places. This clay permits some upward movement of water from the aquifer, and the rising water accumulates in the soil and even on the surface until it is dissipated by evapotranspiration. Experimental pumping in 1930 from a well tapping the artesian reservoir proved that waterlogging can be eliminated by lowering the artesian pressure sufficiently, but none of the waterlogged land has yet been reclaimed by this method.

Imperial Valley, Calif. ${ }^{34}$ The Colorado River has discharged intermittently into this trough-like valley for millions of years and has contributed sediments that are now thousands of feet thick. These sediments are clay, silt, and sand of low permeability, with no known gravel layers of any considerable extent, and there is practically no irrigation from wells. The extensive agricultural areas are irrigated with Colorado River water brought in by the Alamo and All-American Canals. The ground-water problems are those of waterlogging and salt accumulation in the soil, resulting from high water table. By October 1917 , drainage had been provided for 45,000 acres within the Imperial Irrigation District; 1,500 miles of open drains were constructed to aroid the areas of highly plastic and impervious clay, and 1,000 miles of tile drains were installed in the most pervious layers.

In an average year the water imported for irrigation brings in about 2,600,000 tons of salt, and the drains carry out about 2,300,000 tons. More than 300,000 tons of salt

34 Reference: Aronovici, V. S., W. W. Fox, and W. W. Donnan, "Imperial Valley Drainage Investigation," U.S. Soil Cons. Service, Progress rept., 1914. 
are left each year in the area, an average of 1 ton per irrigated acre. The increasing salinity of the soil has been accompanied by declining per-acre yields of alfalfa, flax, and winter vegetables. Excess irrigation to remove this salt creates another problem, for the water accumulates in the Salton Sea, and that saline body has been gradually rising to inundate the lowermost cultivated lands.

\section{Disposal of W WASTES}

There are numerous examples of local contamination of ground water by the disposal of wastes, in some cases forcing abandonment of wells. If artificial recharge of underground reservoirs becomes a general practice, such contamination is likely to become more common, unless adequate precautions are taken to prevent recharge by contaminated water.

\section{SEWAGE}

The disposal of sewage, estimated at 80 to 100 gallons per day per capita, has caused gross pollution of many rivers, and not a stream draining inhabited regions can currently be considered safe for drinking without treatment. Although a sizable proportion of the sewage goes into cesspools, septic tanks, ponds, or shallow underground leaching devices, the danger of drawing polluted water from wells is far less than in the case of streams. In the recorded instances of polluted water drawn from wells, the great majority have been traced to introduction of contamination at the well and thus indicate faulty well construction; records of an aquifer yiclding contaminated water are rare.

If powerful influences of protection or purification were not at work in nature, it would be almost impossible to find unpolluted water anywhere. As far as intestinal bacteria are concerned, the accepted standard of safety of water for domestic purposes is in the order of one organism per 100 cubic centimeters, or one ten-millionth the degree of pollution that is in sewage. In a large part of the country the ground-water 
resources would be rendered unsafe for use in a few days if dilution alone were the factor of protection. But other factors are at work, as summarized by Stead: ${ }^{35}$

Sewage bacteria applied to the surface of the ground or slightly below it may never leave the top few feet of soil, they may be completely removed by downward percolation through porous soil, or, even though they reach water table they may be stranded by a falling water table, travel only in narrow bands in the direction of ground water flow and the length of the band is limited to the distance the water moves in two or three weeks. Ground-water velocities vary but are usually in terms of not more than a few feet per day, so that travel horizontally of sewage bacteria for distances greater than a few hundred feet is extremely rare. Furthermore, the general pollution of deep water strata with sewage bacteria to any alarming degree is virtually an impossibility.

The above discussion applies to liquid sewage discharged to the surface of the ground or the shallow leaching devices in soils or fine sands. Disposal to coarse uniform-sized gravels, cavernous limestone formations, lava with underground channels, or by direct discharge to coarse water-bearing formations would permit much greater travel of pollution, and therefore no such disposal can be considered safe.

Stead also points out that although a very few sewage bacteria can survive for months in ground water, more than 99 per cent will die in ground water within two or three weeks. The minimum limits of safety from a polluting source are therefore determined in large part by the velocity of downward percolation and of lateral ground-water movement. The permeability of the materials through which the water must move is thus a critical factor. It has been found that as little as 10 feet of downward percolation in fine sand is capable of removing all bacteria from water. ${ }^{36}$ Wells along the banks

35 Stead, F. M., "A Discussion of Factors Limiting the Bacterial Pollution of Underground Waters by Sewage," Report of Interior Fact-finding Committee on Water Pollution to the Assembly of the State of California, pp. 138-139, 1949.

36 Caldwell, Elfreda, Studies of Subsoil Pollution in Relation to Possible Contamination of Ground Water from Human Excreta, Jour. Infectious Diseases, vol. 62, no. 3. May-Junc 1938. 
of the Ohio River at Parkersburg, W. Va., and at Charlestown, Ind., depend upon infiltration of water from that highly polluted stream; tests have shown the pumped water at nearly all times to be within safe limits as to bacterial content. ${ }^{37}$

The Public Health Service recommends that rural wells be at least 50 feet from any possible source of pollution, 100 feet from seepage pits and barnyards, and 150 feet from cesspool sources of pollution, ${ }^{38}$ but these limits and others recommended by state agencies are largely empirical, because there has been very little research as to the distance that bacteria may travel through specific rock materials and live to endanger public health. It is impossible at present to designate reliable limits of safety for specific areas. As a result public health may be endangered by existing methods of supply and disposal in some places. In other places regulations based upon squeamishness rather than scientific knowledge require disposal systems that go far beyond an adequate protection of public health and may involve unnecessary cost in money or waste of water.

The danger of bacterial pollution is likely to be greatest in limestones and other very permeable materials. Recent outbreaks of typhoid fever and gastroenteritis have resulted from pollution of private and municipal water supplies in Fillmore and Olmsted Counties, Minn. The pollution of these supplies was traced to sinkholes and stone quarries through which partly treated scwage and escreta were being introduced into the limestone aquifer which yielded water to the supply wells. ${ }^{39}$ Many springs issuing from limestone discharge polluted water in the Tennessee Valley, in the Ozarks, and other limestone regions. Drainage and waste-disposal wells are likely

37 Jeffords, R. M., Ground-water Conditions along the Ohio Valley at Parkersburg, West Virginia, W. Va. Geol. Survey Bull. 10, pp. 46-49, 1945.

Kazmann, R. G., River Infiltration as a Source of Ground-water Supply, Am. Soc. Civil Eng. Trans, vol. 113, pp. 411-412, 1948.

38 "Joint Committee on Rural Water-supply Sanitation," U.S. Public Health Serv. Supp. No. 185 to Public Health Rept., pp. 17-18, 1945.

39 Kingston, S. P., Contamination of Water Supplies in Limestone Formation, Am. Water Works Assoc. Jour., vol. 35, pp. 1450-1456, 1943. 
to cause pollution of aquifers at Orlando, Fla., ${ }^{40}$ and there are at least half a clozen areas in Florida where pollution of ground water may be expected because of disposal of servage and citrus and industrial wastes into limestone aquifers.

In many places sewage disposal into the ground has caused a measurable increase of certain chemical constituents, especially of nitrates and chlorides, in the ground water. Boron, from the borax used in household and industrial plants, has been found in solution in the outfall sewers of Orange County, Calif., in amounts that would be prohibitive in irrigation water. ${ }^{41}$ The problems of chemical constituents in serage are similar to those contributed to ground water by industrial wastes, discussed below.

\section{CHEMICAL WASTES}

Industrial wastes are the major source of soluble nonputrescible wastes, although as noted above sewage also may carry significant quantities of soluble inorganic material. The industrial waste materials occur in almost every possible type and concentration. There have been numerous instances of contamination of ground water by wastes discharged into pits or ponds or otherwise allowed to seep into the ground. When those wastes enter ground-water reservoirs, dilution occurs so slowly that the effects are always long-lasting.

The disposal of brine pumped from oil wells has contaminated the ground-water supplies in several parts of the country (page 149). Wells in some areas have been contaminated by less common types of soluble matter: arsenical wastes at Pine Bluff, Ark.; chromium wastes at Crystal Springs, Calif.; acid mine wastes at Miami, Ariz.; phenol at Fort Myers, Fla. In the Canton district of Baltimore the shallow aquifer is contaminated by wastes acid enough to corrode the casings of wells (page 131).

40 Unklesbay, A. G., "Ground-water Conditions in Orlando and Vicinity, Florida," Fla. State Board of Cons. Rept. of Investigation 5, 1944, 72 pp.

41 Bailey, Paul, "Pollution of the Water Supply of Orange County by Industrial Wastes," Report of Interim Fact-finding Committee on Water Pollution to the Assembly of the State of California, p. 142, 1949. 
The contaminating materials in many places are not products of industrial processes but rather unusable by-products of development of other resources. Around Saginaw Bay, Mich., the usable ground water is being contaminated by highly mineralized waters that flow out of thousands of abandoned holes which were drilled in a search for coal. Many streams flowing from the coal regions, especially in Pennsylvania, are contaminated by acid waters pumped from the mines.

The discharge of industrial wastes into streams has had both direct and indirect effects upon the ground water along certain watercourses. The ground waters along the Arkansas River and several other streams are more saline than they would be under natural conditions because of discharge of brines into them, and subsequent seepage into the alluvium. In the Philadelphia-Camden area a progressive increase in chemical constituents in water from several wells is attributed to the great pollution of the Delaware and Schuylkill Rivers, which cross the recharge area of the aquifer tapped by those wells (page 149). As an indirect effect of industrial wastes, the yield of some wells at Kalamazoo, Mich., appears to be adversely affected by the discharge into the river of paper-mill wastes which collect along the river bottom and impede the infiltration that replenishes the wells.

Our rivers have become the great sewers of the nation, and it is inevitable that one of their functions will always be the disposal of some of the waste from living processes as well as industrial process. This waste may render the stream water unusable for others unless it is sufficiently diluted, and many states require that certain wastes be discharged into a stream only when there is sufficient water for adequate dilution. Fortunately, many of the harmful forms of pollution can be eliminated by treatment before the waste is discharged, and, fortunately too, polluted streams are not permanently affected and may eventually be restored by correction at the source of the pollution. However, if ground water becomes contaminated by infiltration from the polluted stream, the pollution problem may be far more serious. Wherever wells pump water 
replenished by river infiltration, the ground water will eventually be contaminated by the soluble chemical wastes carried in the stream.

\section{River Control}

\section{RESERVOIRS}

River-basin development for flood control, storage, and navigation has had many incidental effects upon ground-water storage, recharge, and discharge. Some reservoirs have increased the yield from underlying ground-water reservoirs, sometimes at serious disadvantage to storage in the surface reservoir. The McMillan Reservoir on the Pecos River in New Mexico leaks rather profusely into beds of gypsum, and this water reappears in the Major Johnson Springs a few miles downstream. When the reservoir is full, the discharge of these springs approaches 250 cubic feet per second, compared with a minimum discharge of 33 cubic feet per second when the reservoir is empty. ${ }^{42}$ The Pine View Reservoir on the Ogden River in Utah overlies the Ogden Valley artesian reservoir, which is the principal source of water for the city of Ogden. That city is reaping the benefit of a substantial reduction in natural ground-water discharge effected by Pine View Reservoir.

Ogden Valley, Utah. ${ }^{43}$ The city of Ogden obtains all but a small part of its municipal water supply of about 15 million gallons a day from an artesian reservoir in Ogden Valley, where the city is the only appropriator. The water flows out by artesian pressure in the valley, which is 12 miles east of the city and at an elevation high enough that the water is distributed throughout the city without resort to pumping. The artesian reservoir is filled to capacity nearly every year during the spring runoff from melting snow, and proba-

12 U.S. National Resources Committee, Regional Planning, Part 10. "Pecos River Joint Investigation, Summary, Analysis and Findings," Nat. Res. Planning Bd., p. 59, June 12, 1942.

43 Reference: Thomas, H. E., The Ogden Valley Artesian Reservoir, Utah State Engr. Tech. Pub. 2, 1945, 37 pp. 
bly some water is rejected in the recharge area in most years. The city has been able to increase its draft on the artesian reservoir from 11,700 acre-feet in 1934 to 15,400 in 1948 without causing more than seasonal depletion of storage.

Pine View Dam, completed by the Bureau of Reclamation in 1936 in Ogden Canyon about a mile below Ogden Valley, creates a reservoir with a capacity of about 45,000 acre-feet. This surface reservoir covers only a part of the artesian reservoir and is separated from it by the clay confining layer that creates the artesian conditions. The weight of water in the surface reservoir has compacted this clay and probably reduced the upward leakage from the artesian reservoir. At any rate, when the surface and artesian reservoirs have been filled to capacity in recent years (both reach capacity approximately simultaneously), water levels in observation wells have been about 15 feet higher than the highest level reached before Pine View Dam was constructed. The maximum discharge from the city's flowing wells has increased from 22 to 33 cubic feet per second since the dam was constructed.

\section{REGULATED FLOW}

Ground-water reservoirs recharged chicfly by streams commonly receive their greatest replenishment when the streams are at high stage. Investigations in the intermontane valleys of the West and in the watercourses in various parts of the country have shown that the recharge is greater because the fine materials are swept from the channel bed at high stages and because the hydraulic gradient between the flood crest and the adjacent ground-water reservoir is most favorable for recharge. During periods of low flow the conditions may vary widely from place to place: the entire flow of some streams seeps into permeable materials of the channel except for small losses by evapotranspiration; silt or clay dropped in the beds of other streams may prevent seepage to the ground-water reservoir; in other places the water table in adjacent alluvium 
may be higher than the stream level, so that ground water is discharged into the stream.

The effects of river regulation are most marked on those ground-water reservoirs which under natural conditions are recharged chiefly during floods and at other times are insulated from the stream by fine sediments in the channel. Obviously if the flood peaks are eliminated and the period of insulation extended indefinitely, the replenishment to the ground-water reservoir will be less than under natural conditions. The maintenance of "pool" stages for navigation is especially likely to affect recharge of ground-water reservoirs adversely, because these pools generally are silt traps, and the stream bed under them may be made relatively impermeable.

Adverse effects upon ground-water reservoirs should not be considered as arguments against flood control, for the potential damage from floods may far outweigh the value of groundwater reservoirs along the stream. But the ground-water reservoirs do constitute an important resource, and comprehensive plans for river-basin development should consider the effects upon them of structures designed to regulate the flow of the stream. In places where the only feasible solution to flood dangers is a flood-control structure that will reduce the natural recharge of ground water, alternate artificial means of replenishment should be sought.

\section{LEVEES AND FLOOD WALLS}

The intimate relation between surface water and ground water in watercourses has been shown by scientific research at many places where the ground water has been developed (pages 136-160). Efforts to restrict the surface water to certain channels and thus prevent inundation of the adjacent flood plain have also given proof of this intimate relationship. At Lawrenceburg, Ind., a flood wall protects the town from floodwaters of the Ohio River. But the river at flood stage also provides significant natural recharge to the ground-water reservoir under the town. In order to prevent "inundation" from be- 
low, the protection of Lawrenceburg is invested partly in.162 wells. These operate without pumping when sufficient head is developed during floods. The wells, located along the toe of the protection embankment to assure its stability, have served this purpose well during prolonged periods of high water, discharging into a collector main by free flow. However, during the high water of the spring of 1919 , ground water rose high enough to cause two minor sand boils and several areas of seepage at a considerable distance from the embankment. Neutralizing measures were not required at that time.

Levees and flood walls must of necessity restrict not only the water but the sediment of the stream to certain channels, and the protected flood plain ceases to receive the sediment which under natural conditions would have been dropped upon it. The sediment dropped in the channel necessarily raises the stage of the river for equivalent flows, necessitating higher levees. The ineritable result along many of the larger rivers has been that the stream is now flowing at elevations appreciably higher than under natural conditions, and at times appreciably higher than the adjacent flood plain. As an evidence of the close relation between the stream and the ground water, the water table has risen rather gencrally under the areas outside the levees, and thousands of acres have been waterlogged.

\section{Navigation Channels}

The dredging of navigation channels has contributed to the deterioration of some ground-water reservoirs along the Atlantic Coast, by facilitating the morement of salt water into them. At Runyon and Cape May, N.J., and at Lewes, Del., pumping from wells has lowered the water table below sea level in shallow aquifers and has thus produced gradients favorable for movement of sea water from the coast. But at each place the aquifers were evidently protected from the sea water by a relatively impermeable clay blanket. Where this clay was removed by dredging for navigation, the ocean water has been able to enter the aquifer, and notable increases in salin- 
ity have been recorded in water from wells near the ship channel. The aquifers affected by dredging in these areas are small and largely dependent upon local recharge. The increase in salinity has been significant so far only in wells within a short distance of the dredged channels.

In some areas where proposed navigation channels would cross recognized ground-water reservoirs, scientists have endeavored to forecast the effect of the channel upon the groundwater resources. In New Jersey, studies of available groundwater data have shown that the proposed intracoastal waterway would probably affect several of the state's important groundwater reservoirs in a variety of ways. In Florida the effect of the proposed Atlantic-Gulf ship canal was the subject of considerable controversy in the 1930's.

Intracoastal Waterway, N.J.44 A canal across the heart of New Jersey from the Raritan River to the Delaware River would provide a direct route for water traffic between New York and Philadelphia. But such a channel must cross the recharge areas of some of the state's most productive groundwater reservoirs and if the channel were dredged to sea level and permitted access of salt water to those aquifers, deterioration and abandonment of many developed well-water supplies would be inevitable. Accordingly the canal as proposed by the Corps of Engineers in 1945 would be a lock canal with a top level 10 feet above mean low water at Sandy Hook. The upper level of the canal would be protected against salt water by specially designed locks from which most of the salt water would be removed by flushing during lockage operations. Model studies at Vicksburg indicated that the salt content could be held below 15 parts per million in the locked canal, except within 2 miles of the locks at Sayreville where it might rise to 30 parts per million of salt.

44 Reference: Barksdale, H. C., and C. E. Jacob, "The Effect of the Proposed New York Bay-Delaware River Section of the Intracoastal Waterway on the Ground Waters of New Jersey," U.S. Geol. Survey, Typed rept., 1945, $66 \mathrm{pp}$. 
In the northernmost 7 miles of the proposed lock canal, the maintenance of the upper level at 10 feet above mean low water would create a shallow pool. Where this pool covers the intake areas of important aquifers, it would furnish substantial recharge to them, and the water supplies for such cities as Parlin and Perth Amboy might gain some quantitative advantage from the canal. However, wells recharged by canal infiltration would yield water containing about the same concentration of salt as the canal water (forecast 30 parts per million of salt at Parlin). Farther south, the Duhernal wells (see page 12S) pump water for chemical processes where the tolerance is in the order of 10 parts per million of chloride. It has been estimated that after construction the canal would furnish about three-fourths of the supply to the Duhernal wells, and the permissible limit of salt content in the canal water would therefore be about 20 parts per million of salt.

Farther south the canal would cause a material lowering of the water table, and numerous domestic and farmstead wells would need to be deepened. A less immediate but ultimately more important effect would be the lowering of water levels in artesian wells south and east of the canal route as far as the Atlantic Coast. These aquifers are believed to contain salt water held in balance by the artesian head of the fresh water in them. The lowering of artesian head by construction of the canal would probably permit the salt water to advance inland over a band several miles in width, and wells within this band would yield water of poorer quality. Available information as to the position of salt water in the aquifers is meager, but the water supplies most likely to be affected are those along the Atlantic Coast from Asbury Park to Sandy Hook, and along the southeast shore of Rari$\tan$ Bay.

To stmmarize, the proposed lock canal of the Intracoastal waterway in New Jersey would probably decrease the available ground-water supplies in some areas and augment them in others; wells in some areas would ultimately pump water 
of a quality similar to that in the canal nearby; and there may be an increase in salinity of water in some wells remote from the canal.

Atlantic-Gulf Ship Canal, Florida. ${ }^{45}$ A waterway across Florida has been the subject of intermittent study and debate since the days of President Jackson, for such a canal would eliminate the expense and danger attendant upon navigation of the long route around the Florida peninsula. By 1934 plans had crystallized to the point of selecting the most feasible route, and construction was begun in September 1935. The Congress, however, did not appropriate the funds necessary for the completion of the project, and activity ceased after a few months of canal excavation and channel realignment. A major factor in the discontinuation of the project was the reasonable doubt as to the deleterious effect of a sea-level canal upon Florida's important groundwater resources.

The route selected for the canal extended from Jacksonville southward toward Ocala and thence westward to Port Inglis (about 80 miles north of Tampa). The waterway would have a length of 195 miles from deep water to deep water, of which 90 would be an artificial cut through the earth and rock of central Florida. The route was the most economical of 28 routes investigated, for it traverses a saddle in the backbone of central Florida where the natural land surface rises to a maximum 108 feet above sea level. The canal would traverse a trough in the piezometric surface of the principal artesian aquifer, toward which ground

45 References: "Waterway from Cumberland Sound, Georgia and Florida, to the Mississippi River; Geology and Ground Water," U.S. Engineering Office, Jacksonville, Fla., December 30, 1933.

Beckman, H. H., "Documentary History of Florida Canal," 74th Congress, Senate Doc. No. 275, pp. 159-161, 409-415, etc., 1936.

Thompson, D. G., O. E. Meinzer, and V. T. Stringfield, Effect of a Sea-level Canal on the Ground-water Level of Florida, Econ. Geol, vol. 33, pp. 87-107, 1938. 
water moves both from the north and from the south, and in which there is considerable discharge from large springs.

Studies prior to 1934 indicated that the canal must have a low-water elevation as much as 40 feet above sea level in order to prevent depletion of the ground-water reservoir. On the other hand, construction of a lock canal across Florida would raise perplexing problems as to location, design, and construction of locks. The limestone through which the canal must pass is so permeable that extensive treatment of foundations and abutments for all locks and dams would be necessary, and geologic conditions at the proposed lock sites were generally far from satisfactory. Accordingly it was decided to construct a sea-level canal.

A sea-level canal would intercept enormous volumes of ground water and would lower the water table at the canal by as much as 40 feet. Wide differences of opinion have been expressed as to the area which would be affected by this draining of ground water. Some reports state that the effect would be limited to a zone extending 10 or 15 miles on each side of the canal. On the other hand, ground-water hydrologists have pointed out that if the canal were constructed water levels might well be lowered in a more extensive area; that the discharge of many springs near the canal would probably be reduced; and that in some areas, such as the celery-growing area in the vicinity of Sanford, there would be danger of increasing salinity of water from irrigation wells. Hydrologic studies far more detailed than those yet made would be needed to determine quantitatively the effect of the proposed canal upon the ground-water resources. 


\section{OUR INGREASING REQUIREMENTS FOR WATER}

All statistics indicate a prodigious increase in the use of water in the United States in the past half century, and particularly in the last 20 years. But a word of caution is necessary: no comprehensive national survey of water use has ever been made, and the statistics are based on very meager information. The most reliable data available for the nation pertain to public supplies and were obtained in independent inventories by the U.S. Public Health Service and the American Water Works Association in 1945. ${ }^{1}$

According to data from 15,370 communities, the average per capita use ranged from 60 gallons per day in communities of less than 500 population to 140 gallons per day in cities of more than 10,000 , with national municipal use about 127 gallons per day per capita. At this rate the nation is now using about 12 to 14 billion gallons a day for municipal supplies. The rural domestic use of water is estimated to be 3 to 5 billion gallons a day additional. According to recent estimates of the National Resources Security Board, the Geological Survey, and others, the nation also uses 75 to 100 billion gallons of water a day for irrigation, 35 billion for generation of steamelectric power, 35 to 45 billion gallons a day for other industrial purposes. The total for domestic, municipal, industrial, and agricultural use of water thus becomes of the order of 160 to 200 billion gallons per day, which is roughly 12 to 15 per cent of the total flow of streams to the ocean.

1 Langbein, W. B., Municipal Water Use in the United States, Am. Water Works Assoc. Jour., vol. 41, pp. 997-1001, 1949. 
The prospects are that our requirements for water for these purposes will increase considerably, and the National Security Resources Board estimates that total water use in the nation may double in the near future. As pointed out by Sayre: ${ }^{2}$

Each new industry will require water and some of them, such as the application of nuclear fission as a source of energy, and the hydrogenation of coal and oil shale, will require enormous amounts. No figures are available for the probable use of water in harnessing atomic energy, but fragmentary information shows that it may be very large. The quantity of water needed for producing 10,000 barrels of oil per day by hydrogenation of coal is estimated at 5.5 to 6.5 million gallons per day, depending on the process used. Of this amount about 80 per cent is consumed. This is the requirement for the operation of the plant only. To this figure must be added the amount that will be needed for the municipalities that will spring up to house the employees of the plant and for the associated service industries. Plans are going forward for large additional developments of irrigation in the W'est. In the East, especially on Long Island, supplemental irrigation to provide optimum moisture conditions for optimum growth of crops has spread very rapidly in the last few years. Inasmuch as the increased productivity that results from supplemental irrigation frequently makes it possible to finance the cost of the installation out of the first year's profits, it is to be expected that this activity will spread rapidly throughout the humid parts of the country and that eventually supplemental irrigation of suitable crops will be practiced wherever local sources of irrigation water are available.

Water is also used for generation of hydroelectric porter, waste disposal, navigation, and recreation. It is estimated that about 1,000 billion gallons a clay flows through existing hydroelectric plants, which is equivalent to about 80 per cent of the runoff from the United States (of course some water flows through more than one plant); the potential development of hydroelectric power is estimated to be about six times as great as the present development. Waste disposal requires large

2 Sayre, A. N., "Water Resources of the United States," U.S. Geol. Survey, Mimeo. rept., pp. 3-4, 1949. 
volumes of water wherever regulations specify that the waste products be amply diluted. The use of water for navigation is a ticklish question in the development of the Missouri River Basin, where navigation will require minimum flows of water that might be used alternatively for irrigation or other purposes. But to compute the amount of "use" for navigation is difficult. If navigation "use" is defined as the quantities released from reservoirs to maintain a minimum depth of channel for river navigation, the quantity may be significant on such streams as the Missouri. It is no easier to compute the "use" of water for recreation. The recreational value of a lake or reservoir becomes nil when it is emptied in order to use the water for other purposes, and if the lake level is held constant for best recreational use, that "use" might be computed as equivalent to the quantities which have not been taken for other purposes. Computation of the total water used for power, waste disposal, navigation, and recreation might easily give figures far greater than the total runoff from the country.

It is obvious that some water is being used more than once, and some a good many times. In order to relate usage of water to water resources, it is necessary to distinguish the quantities that are consumed by use, from those which remain in the liquid state although the chemical or physical properties of the water may be changed by use. The water that is consumed is taken from surface or subsurface resources and returned as vapor to the atmosphere and thus completes its hydrologic cycle sooner than it might under natural conditions.

\section{Consumptive Use and Waste}

Water returns to the atmosphere by evaporation or in the special cases where it has first served living processes, by transpiration or perspiration. Of the water used by men, these are the consumptive uses. They constitute elements of varying importance in the domestic, industrial, and agricultural use of water. Transpiration by the plants of economic value is $\vec{a}$ use of great benefit to man, but that water is derived from soil 
moisture. The consumptive-use draft on the surface- and ground-water resources varies from place to place and varies seasonally, but is increasing progressively as the human population and its standard of living rise. Perhaps a separate category should be made for the water taken from its place in the hydrologic cycle and put in storage for an indefinite period in plant and animal tissues or in canned foods or other products. The release from this storage enables the sugar-cane processing industry, for instance, to show a "negative" consumptive use of water: the water for disposal is greater than the amount used in processing, because of the water squeezed out of the canes.

Consumptive use accounts for only a fraction of the water in the major categories of use by man. It is negligible in production of power, navigation, disposal of wastes, and recreational use, except for the evaporation from water surfaces exposed for those uses. Of the water applied for irrigation, as little as half may be used consumptively, and probably considerably less than half the municipal and domestic supplies is actually consumed. Generally only a small proportion of industrial water is used consumptively, but there is a wide range among the different industries. The consumptive use of water in irrigation, industry, and public supply may be of the order of 50 to 80 billion gallons a day, which is about 4 to 6 per cent of the average stream flow. On the basis of a natural return to the atmosphere of 3 trillion gallons a day, our consumptive use of surface and ground-water resources has increased this return by 2 or 3 per cent. This is by no means the total consumptive use of the water that falls as precipitation. Nearly three-fourths of the precipitation water is returned to the atmosphere by evapotranspiration, of which an unknown proportion represents the consumptive use of agricultural crops. Unless the crops are irrigated, however, their consumptive use is generally not derived from the net surfacewater and ground-water resources.

It has become rather common practice to label all transpiration as "consumptive use" by vegetation. Many plants have very little utility for mankind, and some could be classified as 
"adverse users" in the sense that they not only compete with man for the water but wrest from him the land which he would prefer to use for other purposes. To qualify the term "consumptive use" as widely applied, there have of necessity sprung up adjectives as "beneficial" or "nonbeneficial" consumptive use. The writer feels that "consumptive use" should be restricted to the consumption of water that has some recognized benefit to mankind and that it should not be extended indiscriminately to all transpiration. Admittedly many plants have sufficient value for holding the soil in place or for aesthetic appeal or other purposes to warrant classifying their transpiration as a "consumptive use," but man should be the judge.

The water that returns to the atmosphere without benefiting man might better be termed "consumptive waste." Particularly in the arid closed basins of the West, where all the water from precipitation returns ultimately to the atmosphere, it is important to distinguish the consumptive waste wherever it occurs from consumptive use. Whether the waste occurs by water-loving vegetation or by wasteful irrigation practices, or by evaporation from surface ponds and reservoirs, it is water which might instead be diverted to beneficial use. Within these closed basins such diversion is the only way to derive additional water supplies. In many other parts of the country there is significant consumptive waste available for development whenever supplies become insufficient, and this waste should be identified and segregated in inventories of water resources. The cost of diverting that water to a beneficial use, of course, may be so great as to be economically unfeasible in many areas.

\section{Nonconsumptive Use and Disposal}

Water used without being consumed may remain in the stream, lake, or reservoir of which it is a part, notably in the case of navigation or recreation use. Otherwise it joins either a surface or subsurface water body which may or may not be the one from which it was diverted. Since the water was 
diverted in order to utilize one or more of its chemical or physical properties, it is quite likely that those properties will be affected by the use. Commonly the effect is to render the water less desirable for other users who want to take advantage of the same property, but not necessarily for users concerned with other properties of the water.

The basic properties for which water is used nonconsumptively might be catalogued as chemical or solvent action, of major importance in industrial processing, by which soluble wastcs are carried away from body tissues or from industrial processes or from the soil zone; buoyant action by which solid materials or immiscible liquids are floated or suspended, as in the washing requirements of industry and the disposal of solids in sewage, the floating of logs and ships and the carrying of sediment in streams; release or acquisition of heat, which is essential for both cooling and for heating systems; and the energy it possesses by reason of its position, used for hydroelectric power as well as for transporting wastes or other materials to lower elevations.

Water for public use, whether from municipal systems in urban areas or domestic supplies in rural areas, is largely unconsumed. The unconsumed water goes chiefly into sewage although there may also be some return to ground water from lawns and gardens. The public use generally results in only a slight incrcase of mineral matter in solution, and the principal contamination is by organic materials such as household and industrial food-processing wastes. Of all the materials added to water by use, these organic wastes may be the most serious hazard to public health, but they are also the easiest to eliminate. They constitute only a small proportion of the total volume, for serage is commonly more than 99 per cent water. Natural processes of separation, filtration, dilution, oxidation, and chemical reaction will restore the quality of the used water in time. And to avoid risk, it is possible to achieve any desired purity of the water in sewage by treatment: "primary" to remove the gross solids by settling, "sccondary" to oxidize the remaining polluting materials, and "complete" by sand 
filtration and disinfection with chlorination. Treatment of sewage in order to reuse the water for other purposes and to utilize the sludge for fertilizer has been shown to be economical at many places. ${ }^{3}$

The water used but not consumed in irrigation or industrial processing commonly is deteriorated in quality chiefly because of increase in dissolved mineral matter but in some places because of addition of phenol or other organic residues. The treatment processes for increasing the utility of the water after use are as greatly varied as the types of contamination; they generally do not achieve any great reduction in total dissolved materials but remove the harmful or toxic combinations by chemical neutralization or precipitation. A small but increasing proportion of industrial water is being completely demineralized prior to use by means of resinous ion exchangers. For some contaminated waters the cost of treatment would be so great that other means of disposal have been devised to prevent contamination of usable water supplies. These methods include disposal by trunk-line sewers to the ocean and by wells into brine-bearing formations.

Water used for cooling becomes "polluted" with calories, which does not necessarily vitiate its further use for other purposes and would even be a benefit to the user who expects to heat the water to high temperature. An extreme example of deleterious temperature effects is offered by the Mahoning River in Ohio, probably the most intensively used river in the country. During December 1949 the water diverted from the river was 10 times the average flow of the river, and most of the water was returned after being used for cooling. The temperature of the river approached $140^{\circ} \mathrm{F}$ during that winter month, a temperature so high as to render normal sewagepurification processes ineffective, so that pollution is a serious problem. Here would be an excellent place for a plant that could extract heat from the water.

The potential energy of the water is used chiefly for powver,

3 Veatch, N. J., Industrial Use of Reclaimed Sewage, Jour. Am. Water Works Assoc., vol. 40, pp. 1-7, 1948. 
although it is an essential factor also in water-distribution systems. The use for power causes no deterioration in quality, but it may sometimes be detrimental to the maximum utilization of the water resources, chiefly because civilization has not yet developed a means for large-scale storage of electric power. Water for power is commonly stored in reservoirs catering also to irrigation use, and the generation of power in the winter requires removal from storage of water that might otherwise be used during the following irrigation season.

\section{Anticipation of Future Requirements}

Whether surveyed by type of use or by region, present information indicates that the national need for water will continue to trend upward, possibly even at accelerated pace. Almost certainly the demand for water will increase at a greater rate than the population. Considerably more water will be required for public use to give everyone the standard of living enjoyed by those who already have running water, bathtubs, flush toilets, washing machines, and dishwashers. The garbagedisposal unit is a recent development that will increase the load on both water-supply and sewage-treatment facilities when its use becomes widespread. These household items are nonconsumptive users of water, and the water can be reused after treatment. Home air-conditioning units of the type that cool by evaporation (rather common in the arid Southwest) are consumptive users and will help deplete the available water supplies.

The use of water for irrigation can be expected to increase because of the Federal projects in the West which are bringing water to new lands each year. In the humid regions, too, supplemental irrigation to sustain crops during dry periods has been so profitable that more and more acres are irrigated each year; supplemental irrigation eventually may become standard practice for many crops in the East, Middle West, and South. On the other hand, there are several areas in California, Arizona, New Mexico, Texas, and Utah where ir- 
rigated acreage and pumping from wells have increased phenomenally since World War II and where the cost of pumping has risen as the water level in wells has declined. Several of these are "marginal" areas as far as economic feasibility of pumping is concerned and are probably sustained chiefly by the present price-support structure for farm crops. The rate of pumping can be expected to level off and probably decline when the crops must compete with those from regions more favored in water resources.

The irrigation use that bencfits the farmer is chiefly a consumptive use, although in arid regions downward percolation of excess water also serves a useful purpose in preventing accumulation of saline residues in the soil. Most of the economies that can be effected by more efficient irrigation practices will probably reduce the nonconsumptive use (downward percolation) rather than the consumptive use. Sprinkler irrigation is especially effective in reducing the nonconsumptive use, but this economy can backfire in a ground-water basin where water is fully appropriated and where equilibrium has been established on the basis of substantial downward percolation from irrigation: if any appreciable number of appropriators decide to irrigate new acreage with the water they have "saved," the basin may soon show signs of overdevelopment.

There is a prospect of greatly increased demands for water by industry. If the dominant uses continue to be cooling and washing, the increased demand will be chiefly for nonconsumptive purposes. Air conditioning is already making large demands on existing water-supply systems, and that industry bids fair to expand tremendously in the future. The water used is practically all nonconsumptive, but the quantities of water circulated can seriously overtax existing municipal supply and sewage systems. According to estimates made in 1936, a maximum water requirement of 300 million gallons a day was forecast for the Loop district in Chicago when airconditioning installations reach the saturation point-six

4 Gayton, L. D., Air Conditioning as a Problem of Water Distribution and Disposal, Jour. Am. Water Works Assoc., vol. 29, no. 6, pp. 808-821, 1937. 
times the peak rate in 1929 before air conditioning. This estimate assumed no water-conservation devices. The use of conservation devices such as condensers or cooling towers generally cuts down the water use by 90 to 95 per cent, but most of the water is then used consumptively.

Heat-exchange systems, which use water for year-round air conditioning, are certain to become popular in areas where electric power is cheap enough. Although water is used the year round for heat exchange, the depletion of water resources can be far less than for air conditioning during the summer only. As an example, the water for the heat-exchange system in the 12-story Equitable Building in Portland, Ore., comes from two clifferent aquifers with a temperature differential of $6^{\circ} \mathrm{F} .{ }^{5}$ In winter the system takes the warmer water, extracts the heat, and returns the water to the colder aquifer. In summer the cycle is reversed. Thus one aquifer stores the heat of summer for use in winter, the other stores the cold of winter for use in summer, and there is practically no net loss of water from either.

Several industries of the future may be expected to make large additional demands on water resources. For example, the hydrogenation of coal is an extravagant user of water: on the basis of a tentative estimate of 6 million gallons per day for 10,000 barrels of oil from coal, it would take more than 3 billion gallons a day for synthetic manufacture of oil equivalent to the United States production in 1949. This is nearly three times the quantity of water used by New York City's 8 million people.

An important question is where may these increased demands be expected to occur-because the answer will show whether the present problems in the arid regions or in the centers of population and industry are to be aggravated. Undoubtedly there will be some areas where present conditions

5 Kroeker, J. D., and R. C. Chewning, A Heat Pump in an Office Building, Heating, Piping, Air Conditioning, vol. 20, no. 3, pp. 121-128, 1948; Kroeker, J. D., R. C. Chewning, and C. H. Graham, Heat Pump Results in Equitable Building, Heating, Piping, Air Conditioning, vol, 21, no. 7, pp. 115-121, 1949. 
will become worse, but there are hopeful signs, too. There is a trend toward dispersion of industrial plants and residential areas because of the serious difficulties of traffic, transportation, housing, and plain lack of elbowroom in present industrial and commercial centers. Security in wartime is a great incentive to such decentralization. In addition, an increasing number of water users are becoming cognizant of water in their operations and are selecting sites where ample water supplies will be available.

If the nation's water resources are to meet increased requirements without creating more and more problens than already existing, intelligent development will be essential. Many defects of the present pattern of development need correction, and there is need for more comprehensive planning based on adequate hydrologic knowledge.

\section{The Ground-water Quota in Meeting These REQUIREMENTS}

It is estimated that wells and springs currently furnish about one-sixth of the water for irrigation, industrial, and public use: an average of 25 to 30 billion gallons a day. Ground water is unimportant as a direct source for power, navigation, and recreation, but is of considerable indirect importance because the minimum flow of streams is sustained chicfly by groundwater inflow.

The selection of ground water as a supply, rather than surface-water sources, has generally been on the basis of one or more of the following advantages:

1. Accessibility. Ground water may be reached within a few hundred feet of the place where it is to be used, and on the same property, whereas surface water may require pipelines and rights of way over stretches of several miles.

2. Availability. Ground water may be available for use in areas where the water in streams and lakes has already been appropriated by other users. 
3. Dependability. Yield from wells and springs generally fluctuates less than stream flow in alternating wet and dry climatic cycles.

4. Uniformity in quality. Ground water is more uniform in temperature and soluble mineral load than surface water, and is generally free of turbidity and bacterial pollution.

The absence of these advantages has necessitated the development of water from surface sources in many places where ground water can be obtained only at excessive depth below the surface or where it cannot be obtained in sufficient quantity at any depth; where the ground water is deemed to be fully appropriated or where it is of a quality that makes it unsuitable for the use intended. Ground water has another disadvantage as an alternate to surface water in that the use generally requires expenditure of energy for pumping, whereas the surface water may produce energy in addition to supplying water for other uses. This is a formidable disadvantage in many areas.

A principal disadvantage of ground water, however, is its generally slow movement through rock materials, which mitigates against its successful use to meet the large requirements of concentrated population and industry. Many cities that once depended on wells for supply have been forced to develop other sources more capable of supplying their needs as population and water requirements increased. New York City itself depended on wells, with increasingly unsatisfactory results, until its population reached 200,000 in 1830. Of the 100 largest cities in the United States (1950 census) only 19 depend upon wells for their public supply; 16 of these are among the 60 cities that range in population from 105,000 to 250,000 . Of the 22 cities with population 250,000 to 500,000 only San Antonio and Memphis obtain their municipal supplies from ground water. Houston, Tex., is the only one of the 18 cities of more than 500,000 population that depends upon wells for all its public supplies, and it is turning increasingly to surface 
water for industrial use. It is evident that pipclines and stream channels are far superior to aquifers for transmission of hundreds of millions of gallons a day to points of concentrated demand.

In spite of these evident disadvantages of ground water as an alternative to other sources of water supply, it is likely that an increasing proportion of the nation's expanding requirements for water will be met by pumping from wells. The advantages of uniform temperature and quality, and absence of suspended load, will be paramount for many industrial uses, particularly air conditioning. And any trend away from the present centers of population will spread industrial and public demands over a broader area. Most ground-water reservoirs are at their best when called upon to supply water to widely dispersed wells.

The chief factor favoring additional ground-water developments is the tremendous capability for storage in many ground-water reservoirs. Underground storage can be utilized in many places where surface storage would be extremely costly, either because of the expense of dam construction or because of the loss of valuable land which must be flooded by a reservoir. In arid regions underground storage has the additional advantage of minimizing the loss by evaporation, which may be as much as half the water stored in surface reservoirs of large holdover capacity.

It is true that our efforts to utilize this storage in the past have been unsuccessful enough to bring forth popular articles with such titles as "Are We Running Out of WVater?" But consider the efforts: We pump wells in blissful ignorance of the characteristics which govern the flow of the water underground and then are chagrined when the water is not replaced where pumped out. Generally, ground-water utilization has barely reached the stage arrived at in stream utilization half a century ago, before reservoirs were constructed and when the users were dependent upon the natural flow of the stream. We have depended upon the natural flow through groundwater reservoirs and have experienced more trouble with that 
than with stream flow, because we could not see what was happening underground. The natural flow in many ground-water reservoirs has been sustained both in dry and wet years but generally with more hindrance than help from man.

In recent years there has been an increasing trend toward regarding permeable rock materials as places where water can be stored, rather than merely as places where water is stored by nature (or was until man pumped it out). Many Californians are taking the lead in recognition of the opportunities for putting water underground in storage for future use: the water they propose to work with may be precipitation upon the headwater areas, flood flows or winter flow's of streams that would otherwise continue unused to the ocean, and reclaimed sewage and industrial water. The ground-water storage capacity will be utilized wherever possible for regulating stream flow and for holding water for sustained use. ${ }^{6}$

In several other states the complementary relations of too much water on the surface during floods and not enough underground when it is needed are receiving attention. As an example, the Indiana Flood Control Commission is investigating the potentialities of abandoned glacial valleys for absorbing floodwaters. The prime purpose of the Queen Creek Reservoir now under construction by the Corps of Engineers in central Arizona is to hold back floodwaters just long enough to be absorbed by the ground-water reservoir of Salt River Valley. Experiments have shown that fresh water can be stored and later recovered from an aquifer that produces brackish water under natural conditions. ${ }^{7}$

The ground-water reservoirs along watercourses are certain to be drawn upon substantially to meet increasing requirements for water. The development of ground water there may have the same effect upon stream flow as pumping direct from

- Berry, W. L., The California Water Plan, Jour. Am. Water Works Assoc., vol. 42, no. 4, pp. 381-385, 1950.

Conkling, Harold, Utilization of Ground-water Storage in Stream System De. velopment, Trans. Am. Soc. Civil Eng., vol. 111, pp. 275-354, 1946.

7 Cederstrom, D. J., Artificial Recharge of a Brackish-water Well, The Com. monwealth, vol. 14, pp. 31, 71-73, December 1947. 
the river, but this may be no handicap to users of the rivers that discharge surplus water continuously into the ocean. In many places ground water is superior to the stream water for certain uses, because of uniform temperature or chemical quality; particularly where the stream is polluted by sewage, the antibiotic action of aquifers will be an advantage. The ground-water reservoir along a watercourse may also be capable of a higher sustained yield than the surface water if the stream fluctuates markedly in discharge, because water can be pumped from storage underground during periods of low stream flow, to be replaced when the stream is at higher stage. Manipulation of storage along watercourses can also be used to advantage in reducing flood peaks. 


\section{GURRENT DEFIGIENGIES AND FUTURE NEEDS FOR EFFEGTIVE GROUND-WATER DEVELOPMENT}

Utilization of ground-water reservoirs for the greatest benefit of civilization is dependent first on adequate hydrologic data, from which the full potential of development is determined. A second factor of major importance is the permissive limit of developinent which is set by legal concepts; if development is not to be unduly restricted, it is essential that these concepts be based on broad scientific principles and adequate hydrologic data. The practical limit of development and utilization of ground water will be set by the general public, who must weigh the value of the water to them against the cost of obtaining it, and this limit is thus dependent on the degree of enlightenment of the citizenry as to the possibilities and limitations of ground-water reservoirs in meeting their requirements for water.

\section{Hydrologic DATA}

We do not know enough about most ground-water reservoirs to give a quantitative answer as to their potentialities or limitations for development. This has been apparent from the discussions of the specific problems in preceding chapters. But those descriptions do not give a true picture of the state of our knowledge on a nationwide basis, for in order to draw any conclusions at all, it was necessary to select those areas where some studies had been made of ground-water conditions. Far less is known about the parts of the country not mentioned, and in those areas we lack the knowledge necessary to make 
the most effective development of the ground-water resources.

With so little knowledge of the ground-water resources, it is inevitable that those resources are generally neglected in the "integrated". development of all water resources of major drainage basins. Thus the program for Tennessee Valley is dominantly one of river development for power, navigation, and flood control, and records of stream flow and precipitation furnished the basic data for the program. The program of more effective land use, with its advantages of decreased soil erosion and increased storage of soil water, has subsequently become increasingly important. It is estimated that ground water contributes an average of 50 per cent of the annual flow of the streams and that some rocks are so permeable that abundant water supplies flow through them, in some instances carrying sediment and bacteria, so that there are serious problems of ground-water pollution. But so little is known about ground-water occurrence that the obtaining of adequate supplies from wells is largely a matter of chance, and there is still no basis for evaluating ground-water reservoirs as integral parts of the Tennessee Valley's water economy.

Similarly in the Missouri Valley the authorized plan for development is a stream-development program. Programs for land use were proposed subsequently, and the ground-water potentialities are still very little known. In the Columbia Basin, available basic data are generally agreed to be sufficient to justify the dams already under construction; but we do not by any means have the information fundamental to a determination of the best program of water-resource development to meet local, regional, and national needs. In general, for the comprehensive river-basin programs already formulated, the ground-water reservoirs will not be an integral part but an afterthought which must fit into a program otherwise well along in the design and construction stage.

A major factor in the successful production of ground water for use is the "know-how" of the technicians who are primarily responsible for the development and maintenance of production. In the past two decades there have been great advances in the technical knowledge, procedures, and equipment used 
to get water out of the ground. The well-drilling industry can now obtain large quantities of water from fine-textured materials for which the only treatment years ago would have been a sad shake of the head, and the water can be lifted economically from depths which would once have been considered excessive. The overdevelopment of ground-rater reservoirs in many localities today would not have been possible but for the successful derelopment of pumps, casings, screens, and new drilling techniques by the industry. Some might argue that this very success must result in a decline in well drilling because the industry, like whaling, is exhausting the resource upon which it is dependent. Actually, however, only a small proportion of the nation's important ground-rater reservoirs can be considered "overdeveloped" (see Plates II and III), and the rest of the country still offers vast opportunities for ground-water development. In addition, the industry can look ahead to another field of great promise, hardly explored as yet, in the use of wells for recharge of ground-water reservoirs.

For the development of a ground-water reservoir, involving the interrelationships of many wells, a substantial volume of technical research in a few areas has resulted in far better understanding of the hydraulics of ground-water movement. But the application of these principles to other ground-water reservoirs must await the collection of essential basic hydrologic data. For an individual well a substantial amount of hydrologic data may be obtained as drilling progresses, and particularly where the well is to be one of several to serve the needs of a single user, there is need for analysis of these clata to determine the relationships among the wells. Several progressive drilling contractors, private consultants, cities, and industries have set up technical staffs to meet this need.

Comprehensive analysis of the characteristics and potential development of an entire ground-water reservoir has generally been by public investment, intended to provide fundamental data to all water users, and the task is usually performed by hydrologists of Federal, state, or local governmen- 
tal agencies. Full utilization of ground-water reservoirs is dependent also upon an understanding of the place of each reservoir in the hydrologic cycle. Unfortunately the hydrologic cycle is not studied as a unit but by phases, and the quantitative analysis of the movements of water through it is dependent upon basic data collected by many governmental and private agencies, and also upon data not yet being collected because no satisfactory means have yet been devised.

In very few areas in the United States have hydrologic data been collected and studied for a long enough period to point the way toward a firm program for the fullest utilization of the available water resources. For nearly all the country there is great uncertainty as to the magnitude of the storage or natural replenishment of water in the ground or the extent to which man has modified or can modify the natural conditions. A prerequisite for full development of water resources in these areas is adequate technical information, including both the basic data necessary for application of proved hydrologic principles and research to provide more effective ways for measurement of the water passing through each phase of the hydrologic cycle. With adequate hydrologic data a reliable determination can be made as to the quantity of water that can be yielded perennially by a ground-water reservoir, or more broadly, a drainage basin. Thus the technical data become the basis for determining the full potential of development that can be sustained.

ADEQUATE INVENTORY OF WATER PASSING THROUGH THE HYDROLOGIG CYCLE

In every area where ground-water development has resulted in declining yields, increasing lifts, or encroachment of unusable water in wells, hydrologic data have been essential to a diagnosis of the trouble, and to the development of corrective measures in the areas which have faced critical problems in the past. But the value of data concerning storage and movement and inflow and outflow of water in ground-water reser- 
voirs goes far beyond their use in development of wells that draw from those reservoirs. Because ground water constitutes one phase of the hydrologic cycle, a knowledge of it is important in the development of all water resources, as well as in the effective use of the land to take maximum advantage of the water that falls as precipitation. Conversely, an adequate knowledge of the ground-water phase of the hydrologic cycle requires much data concerning precipitation, infiltration, soil moisture, evapotranspiration, and stream flow, as well as the characteristics of aquifers.

A task force of the Hoover Commission, ${ }^{1}$ in reporting on the weaknesses of the present system of water-resource development, gave first place to the "Deficiencies in Hydrologic Data" and remarked that "our greatest shortcoming has been the failure to provide for the utilization of rain gages, snow surveys, stream-flow measurements, evaporation stations, runoff and erosion studies, ground-water observation wells, waterquality analyses, and other established methods of obtaining data essential to the planning and construction of river development projects." As a first step in overcoming this deficiency, the Hydrologic Subcommittee of the Federal Interagency River Basin Committee called a series of regional conferences in 1949 to ascertain from technical men in the field the places where additional basic data were most urgently needed. The recommendations from these conferences were predominantly for additional stations to measure the two phases of the hydrologic cycle that we already know most about-precipitation and stream flow-and it is quite evident that no phase of the hydrologic cycle is yet considered to be inventoried adequately on a national scale.

Although basic data are the foundation upon which must be based the design and operation of all structures for the conservation and utilization of water resources, those data are valueless without adequate techniques for interpreting and

1 "U.S. Commission on Organization of the Executive Branch of the Government, Organization and Policy in the Field of Natural Resources," Task Force Rept., Appendix L, U.S. Government Printing Office, pp. 18-20, 1949. 
applying them to specific problems. Of themselves the basic data are only a list of figures pertaining to a specific sampling point. With an adequate foundation of the governing principles and the hydrologic characteristics of the area in which the records were collected, an exhaustive analysis can lead to a determination of the volume of water in a particular phase of the hydrologic cycle within a specified area, provided that the basic data are truly representative. Much can be done with existing records, as shown by the Weather Bureau's scientific analysis of normal precipitation in western Colorado, resulting in totals 30 per cent greater than computed by arithmetical averages of the same records. ${ }^{2}$ In general the "exhaustive analysis" and scientific interpretation lag far behind the collection of the basic data for all phases of the hydrologic cycle.

The recommendations made to the Hydrologic Subcommittee of the FIARBC for collection of basic data included very little pertaining to infiltration, soil moisture, ground water, and evapotranspiration-the underground phases of the hydrologic cycle. So little is known about these phases that even the listing of the national needs for additional data is a formidable task. Instruments have not been perfected for measurement of the water in some phases: equipment for measuring soil moisture has recently been designed and is still being tested under field conditions, ${ }^{3}$ and measurement of evaporation and transpiration is a matter for further research and development. Also, it is exceedingly difficult to select sampling points representative of any area of appreciable size, because of the great variability in conditions under which water moves downward from the land surface, laterally, and then to the surface again. The records from these sampling points are not of full value until they can be translated into volumes of water within a particular phase of the hydrologic cycle. In particular, an adequate continuing inventory of the

2 Bernard, Merrill, The Role of Hydrometeorology in Planning the Water Economy of the West, Trans. Am. Geophys. Union, vol. 30, pp. 263-271, 1949. 3 Colman, E. A., The Place of Electrical Soil-moisture Meters in Hydrologic Research, Trans. Am. Geophys. Union, vol. 27, pp. 847-853, 1946. 
water in a ground-ivater reservoir requires much more than the water-level fluctuations in selected wells, although those records are basic in the inventory. The fundamental data needed before these water-level records can serve their full purpose are outlined in a subsequent section.

If the utilization of ground-water resources is to be an integral part of the effective development of all water resources, and more broadly of all natural resources, more must be achieved than the collection, interpretation, and analysis of basic data concerning the separate phases of the hydrologic cycle. The results of that work must be integrated to furnish a quantitative inventory of the water passing through all phases of the cycle. Here is a field still practically untouched. A major difficulty has been the limited scope of the agriculturists, agronomists, biologists, chemists, engineers, foresters, geologists, meteorologists, physicists, and others who are hydrologists at times and in varying degrees; in large part the scope of activity of governmental agencies has been restricted also by legislative authorizations or appropriations. An increasing number of scientists have realized the need for delineating the operations of the entire hydrologic cycle in a drainage basin or other area of study, as a preliminary to comprehensive development, but they have been handicapped by the lack of essential data, especially as to the movement and storage of water beneath the land surface. As a result there has been a common tendency to ignore those lesser known phases of the hydrologic cycle or to guess at their meaning on the basis of studies of precipitation and infiltration and stream flow.

The inadequacy of comprehensive hydrologic research has long been recognized. The National Resources Committee in submitting a report on "Deficiencies in Hydrologic Research" in $1939,{ }^{4}$ stated:

Present information on the significance and interrelation of different phases of the hydrologic cycle contains much that is in need

4 "Deficiencies in Hydrologic Research," National Resources Planning Board, Natural Resources Committee, p. v, 1940. 
of further verification and there is a serious lack of understanding of the significance of many phenomena. Improvement of this situation can best be effectuated by a competently organized and thoroughly coordinated long-range research program given continuity by adequate appropriations. Such an appropriation policy, with provisions for a reasonable and necessary expansion of the facilities, would very largely eliminate such duplication of effort as now occurs as a result of a fluctuating financial support and lack of continuity.

In order to establish a long-range national policy with respect to hydrologic data, Representative Murdock of Arizona has recently submitted a bill to Congress, proposing "to establish a comprehensive and adequate basic-data program in water resources and provide for its maintenance in order that the full potential of the nation's water resources may be developed for all beneficial uses and that there may be adequate hydrologic and geologic data for the effective control, prevention, or reduction of the destructive powers of water."

CHARACTERISTICS OF GROUND-WATER RESERVOIRS. For the effective utilization of a surface reservoir, an essential item is the mapping of the reservoir and the preparation of capacity tables, so that the quantity in storage can be determined from measurements of the stage of the reservoir. Reservoir operation is generally dependent also upon continuing records of the inflow and outflow of the reservoir. Effective utilization of a ground-water reservoir requires measurement of the same items - the quantity in storage, the recharge, and the discharge --plus an item of little significance in surface storage: the rate of movement of water through the reservoir. The techniques for these measurements are more complex, and the fundamental information needed to translate the basic data into volumes of water is far more imposing than the requirements for a surface reservoir.

Delineation of the areal extent and thickness of the rock materials of a ground-water reservoir is primarily a geologic problem. The amount of water in those materials is dependent upon the porosity; the permeability is a major factor in the 
rate of movement of water through the reservoir and therefore in the yield of wells or springs. These several geologic and hydrologic characteristics of an aquifer, plus information concerning the position of the water table or piezometric surface throughout the ground-water reservoir, are the basis for quantitative determinations of storage and movement within the reservoir. Thereafter, changes in storage and movement may be calculated from fluctuations of water level in representative wells.

The amount of recharge may be indicated by the losses from the soil zone, stream, or other ground-water reservoir which has contributed the water. Any increment to storage must also affect the position of the water table in the recharge area. Therefore a coordinated analysis of records of infiltration, soil-moisture storage and discharge, stream seepage, and ground-water storage in the recharge area is needed for a thoroughgoing determination of ground-water recharge. Similarly, determinations of natural discharge from a groundwater reservoir require adequate data as to evapotranspiration, outflow in springs, and seepage to streams, as well as decreases in ground-water storage.

The quality of ground water is a field in itself, of especial interest to the chemist, but of concern to all users of water because most of the mineral matter in water is dissolved from rock materials and therefore comes from ground water. An understanding of variations in quality of water in various parts of a ground-water reservoir requires also a knowledge of the geology and the movements of water in the reservoir.

For several ground-water reservoirs, particularly in the West, hydrologic studies are sufficiently advanced to permit calculation of seasonal changes in storage and of recharge and discharge; estimates have been made of the total volume of water stored in some ground-water reservoirs, for instance, in the High Plains in Texas (page 28). Experience has shown that considerable expense is entailed in the quantitative determination of the hydrologic characteristics of aquifers, particularly where test drilling and special pump installations are involved. 
Even if funds were unlimited, it would take years to complete the work for any major drainage basin, because of the dearth of trained ground-water hydrologists.

Complete information concerning ground-water reservoirs, however, is not necessary unless and until there is a prospect that they will be developed for use. It is likely that some ground-rvater reservoirs will never approach their development potential, because water supplies from other sources are more than adequate for the needs of the region. These reservoirs, however, may be important contributors to stream flow. Records collected from observation wells in conjunction with stream-flow records may show the extent of that contribution. Such studies have enabled the Pennsylvania Water and Power Company to forecast successfully the low-water flow of the Susquchanna River, on the basis of records of water levels in two dozen wells scattered over the 27,000-square-mile drainage basin. ${ }^{5}$ Analysis of these records indicates that the annual range in ground-ivater storage throughout the drainage basin is equivalent to about 3 per cent of the average annual stream flow from the basin but that about 40 per cent of that stream flow is water that has passed through the ground-water reservoirs. In other words, the usable underground storage under present conditions is drained and replenished many times in the course of a year.

INVENTORY OF WATER UTILIZATION. In most of the country there is already some use of water, and a complete inventory of the water passing through the hydrologic cycle would necessarily include an accounting of the water already utilized. The huge figures that describe the national "use" of water have little meaning, unless they are accompanied by an analysis of what the water is used for and what then happens to it. Nor should water be designated "unusable" without saying what it is unusable for, as might be shown by numerous examples:

5 Merriam, C. F., Interpretation of Natural Fluctuations of Ground Water in Terms of River Flow, Jour. Am. Water Works Assoc., vol. 37, pp. 632-637, 1945; Ground-water Records in River-flow Forecasting, Trans. Am. Geophys. Union, vol. 29, pp. 384-386, 1948. 
The skipper of the Queen Wary regards all the inland waters of the United States as unusable, and yet he can use water of any kind, provided only that it is 70 feet deep. Saline ground water in Baltimore is more usable for cooling in industrial plants than the potable public water supply, and it is possible that the return of water to a ground-water reservoir after it has been used (and warmed) for air conditioning might be more detrimental to further use than if the reservoir were replenished instead by cool sea water. The sewage effluent of the Los Angeles area, after complete treatment and percolation into ground-water reservoirs, may well be of better quality for domestic or industrial use than the imported Colorado River water. Along the Pecos River in Texas, both surface and ground waters are used for irrigation, although some have almost half as much mineral matter in solution as sea water, and nearly all would be classed as "unsatisfactory or injurious" for irrigation in other regions. The secret of success along the Pecos is the selection of permeable soils and of crops tolerant to such mineralized waters and the application of a sufficient excess of water to carry off salt residues in the soil. After long-continued use of such inferior water, soils may develop characteristics that make water of better quality "unusable" on them.

An inventory of water utilization should differentiate the use into categories of consumptive use which returns water to the atmosphere, consumptive waste which also returns water to the atmosphere but without benefit to man, and nonconsumptive use, after which the water is returned to surface or ground-water bodics. The quantity used consumptively is a straight deduction from the total water available for use, and the consumptive waste is similar except that it may be possible and desirable to divert some of that water to beneficial purpose.

The water used nonconsumptively may be entirely suitable for further use, but on the other hand it may be so contaminated as to be unfit for further use and if discharged into a stream or ground-water reservoir might even render a 
much larger quantity of water unfit for use. The nonconsumptive use of water is of vital concern to public and private groups interested in water supply, as well as to those concerned with disposal of wastes and the effects of pollution on public health. Their separate efforts would be more effective if they could be more closely integrated.

Several partial inventories of water use or disposal have been made by Federal, state, or regional agencies. The U.S. Public Health Service is maintaining an inventory of all facilities for public water supply and sewage disposal throughout the country. ${ }^{6}$ The Louisiana Stream Control Commission has published representative data concerning the quantity and quality of water required for various industrial and agricultural purposes, the nature and quantity of wastes, and the methods of disposal. The Ohio W Water Resources Board has shown the amount of industrial pumpage of ground water, tabulated as to counties and as to specific industries. ${ }^{8}$ The Interstate Commission on the Delaware has been collecting detailed information as to the sources and quantities of pollution in the Delaware River since 1936 and is now engaged in a major program of corrective measures and improvements financed by the states and the people of the Delaware Basin. ${ }^{3}$ Inventories have been made of water requirements or of water pollution in many other areas, as an essential step toward remedying unsatisfactory conditions. But as yet there is no comprehensive inventory national in scope.

A knowledge of the quantities of water consumed by each user, of the quantity that is used and must then be disposed of, and the characteristics of that disposal water, would help

6 "Inventory of Water and Sewage Facilities in the U.S. 1945" U.S. Public Health Service, 1948.

7 Louisiana Stream Control Commission, Water Conference rept., Baton Rouge, 1946, $60 \mathrm{pp}$.

8 Bernhagen, R. J., Industrial Ground-water Pumpage in Ohio, Ohio Dept. of Nat. Res., Div. of Water, Bull. 11, 1949, 45 pp.

9 Incodel, A Report on the Activities and Accomplishments of the Interstate Commission on the Delaware River Basin for the Year Ending June 30, 1948, Philadelphia, Pa., 1948, 47 pp.; The Delaware River Basin Water Project, January $1951,24 \mathrm{pp}$. 
a lot in seeking solutions for existing problems of water supply and pollution. The ground-water reservoirs can be an integral part of any coordinated plan for improved methods of supply and disposal. In some areas ground water occurs in aquifers sufficiently independent of each other that they can be utilized as tanks to receive or discharge water of certain specific properties: cold water desirable for air conditioning, warm water desirable for boiler feed, soft water desirable for washing, etc. Aquifers containing water unsuitable for most uses might be the recipients of brines and other highly mineralized industrial wastes, as in Kansas where state regulations require the disposal of brines from oil wells into brine-bearing rock formations. On the other hand, there are areas where disposal of waste into the ground at any point would be detrimental to other users of water, and it has been necessary to discharge those wastes into trunk-line sewers or streams specifically designated to function as sewers or into tanks where the fluids can be evaporated.

\section{MANIPULATION OF STORAGE FOR MAXIMUM UTILIZATION} OF WATER

The great majority of wells today are dependent entirely upon the facilities provided by nature for replenishment. In some places the natural replenishment is far greater than in others, and many of these "others" are now facing problems of ground-ivater shortages. In a small but increasing number of areas there have been significant achicvements in putting water into ground-water reservoirs by means of ponds, basins, spreading grounds, and wells (see pages 53, 73, 96, 125, 127, 141-144, 189).

In many other areas storage in ground-water reservoirs has been increased as a by-product of irrigation, sometimes with detrimental effects (pages 89-90, 152, 198). The areas where soil water has been increased by soil conservation practices are widely distributed throughout the country (pages 64$68)$. Throughout the country there is ample evidence that the storage of ground water can be increased by artificial means, 
but the unsuccessful attempts are numerous enough to indicate that there is still much to be learned as to how and where to operate.

In the arid regions there is an increasing awareness of the value of underground storage as an alternate to surface storage, for it has been found that "no matter how large the (surface) reservoir capacity, streams of erratic annual and cyclic flow will yield for useful purposes no more than 50 to 60 per cent of the average annual discharge because the remainder will be lost, over the years, by evaporation from the excessive water surface of the reservoir necessary to impound the water of the infrequent years of large discharge." 10 Factors that tend to make the use of ground-water rescrvoirs attractive, in addition to the saving of water otherwise lost by evaporation, are the increasing cost of gravity developments and the decreasing cost of pumping due to lower power cost and increased efficiency of pumps.

The utilization of ground water may be increased significantly above the limit set by natural replenishment if floodwaters or other surplus waters can be used to increase the replenishment artificially. Thus a coordinated program of flood control and artificial recharge may serve the double purpose of preventing damage from too much water and storing it until it can be used beneficially.

Characteristically the ground-water reservoirs along watercourses receive their greatest replenishment in time of flood. In places where the water table has been lowered by pumping from wells, the replenishment of the ground-water reservoir takes more water from the stream than would be required under conditions prior to construction of the wells. Thus pumping along a watercourse may subsequently cause some reduction of stream flow in time of flood. Here again groundwater development and flood control have a complementary relationship. Watercourses offer some of the best opportunities for development of large additional quantities of water

10 Conkling, Harold, Utilization of Ground-water Storage in Stream-system Development, Trans. Am. Soc. Civil Eng., vol. 111, pp. 279-280, 1946. 
with prospects of adequate replenishment from the river. Full development of the potentialities of ground-water reservoirs along some watercourses would also contribute substantially to flood control.

Many ground-water reservoirs receive the bulk of their natural replenishment by infiltration of precipitation upon the land surface. Increasing the natural replenishment involves increasing the amount of downward percolation, whether by spreading water from other sources, or by reducing overland flow or other avenues of escape of the precipitation. In the great soil groups forming the land surface of most of the country (page 166), the rate of infiltration is influenced by such factors as vegetative cover, tillage, slope, and organisms and organic matter in the soil zone, and good soil-conservation practices have demonstrably increased the rate of infiltration. Where the chief purpose of good land-use practices is to prevent erosion by minimizing the overland fow or to increase the soil moisture for agricultural crops, the very fact of increased infiltration is a mark of success. But any project intended primarily to recharge a ground-water rescrvoir needs more than that in order to merit, say, the financial support of the well owners dependent on that ground-water reservoir. Artificial-recharge projects should be based on a sufficient knowledge of the reservoir characteristics and should be accompanied by tests to show quantitatively what happens to the water applied for recharge.

Artesian ground-water reservoirs are special cases, because the artesian conditions indicate the presence of impermeable material that impedes upward movement of the water and also prevents recharge by downward movement from the land surface. Where wells have depleted the storage in artesian reservoirs, artificial recharge cannot be by infiltration and downward percolation from the surface but must be through wells that puncture the impermeable layer. The alternative is to augment the recharge in the areas of natural replenishment, but this may make no appreciable difference at the wells, at least for a long time, particularly if they are several miles from 
the recharge area. The problems in many developed artesian reservoirs are not due to a deficiency of replenishment in the recharge area but to the slow rate at which water moves from there to the wells.

\section{Legal Concepts}

The legal concepts concerning water, which set the permissive limits of development, have necessarily been founded upon the hydrologic information available at the time they were formulated and thus reflect the incompleteness of scientific knowledge to a degree. The hydrologist can build from scratch in the areas of his most profound ignorance. The specialist in water law has a more difficult job, because legal concepts have been developed even when the hydrologic facts and the underlying basic physical principles were not known. Many established concepts are now known to be scientifically unsound and should be revised in the light of present knowledge. The following discussion is therefore concerned to a considerable extent with the deficiencies of those concepts, deficiencies that must be corrected if sound development is to be made of the water resources.

\section{PROBLEMS OF WATER RIGHTS}

A water right is a right to use the water and is very generally recognized in court decisions as real property, entitled to protection to the same extent as other forms of property. The laws evolved for the definition and protection of water rights are basically limitations on the use of water by others, so that the water shall be available for use by the holder of the right.

A century ago the water resources in the inhabited parts of this country and in England were far more than adequate for the demand, and the "common-law" doctrine enunciated at that time reflected the relative abundance of supply. ${ }^{11}$ Since

11 Acton v. Blundell (12 M. W. 324), 1843. The decision was to the effect that "the person who owns the surface may dig therein, and apply all that is there found to his own purpose at his free will and pleasure; and that if, in the 
that time the use of water has increased prodigiously, and civilization has moved into areas where precipitation is chronically inadequate for its needs. The body of water law has grown apace, particularly in the arid regions.

The importance of water law to the development of the West and the present status of the legal structure evolved in the past century are summarized in a report of the Natural Resources Planning Board in 1943: ${ }^{12}$

In the West, water is scarce and the dependence of agriculture and of grazing upon the limited supply of this indispensable resource has given water an outstanding value. In the East, on the contrary, water is more plentiful and the requirements of agriculture and industry have not resulted in widespread controversies over rights to the use of water. The water law of the West is, therefore, far more fully developed than the law relating to water in the East. It can be said, too, that the urge toward improving the effectiveness of the law of water in promoting conservation and optimum use that is so strong today in the West is almost nonexistent in the East where the problem is much smaller, existing defects are less important, and interest in improving the operation of the laws almost not apparent. . . .

From a small beginning in the gold mining regions of California nearly one hundred years ago the western states have erected a structure of water law's without which the present development of western agriculture would not have taken place. Dams have been built, ditches dug, farms and orchards planted, and communities established with reasonable assurance that protection would be afforded in the continued exercise of their all-important water rights. The fundamental principles of water law, upon which the largest part of this development has been predicated, have been tested under widely varying circumstances and have proved sound and workable. Nevertheless, the structure is most intricate in its present design and operation and it would be erroneous to con-

exercise of such right, he intercepts or drains off the water collected from the underground springs in his neighbor's well, this inconvenience to his neighbor falls within the description of damnum absque injuria, which cannot become the ground of an action."

12 "State Water Law in the Development of the West," Natural Resources Planning Board, Subcommittee on State Water Law, pp. 1-2, 1943. 
clude that it is now perfect. Although it has undergone many changes during the past century many gaps and inconsistencies are still apparent and difficult problems of administration remain unsolved. The Subcommittee believes that in this segment of the field of water law a real opportunity exists to secure legislative modifications of the law governing the acquisition and management of water rights that will facilitate the wisest conservation and use of water.

The Supreme Court has stated: ${ }^{13}$ "As to every stream within its domain a state may change this common-law rule and permit the appropriation of the flowing water for such purposes as it deems wise..." Statutes and court decisions of several states now define water rights on the basis of several factors in addition to, or in substitution for, the exclusive common-law basis of landownership. Some of the factors and the problems involved in their definition are discussed below.

WATER RIGHTS INHERENT IN LAND OWNERSHIP. The commonlaw doctrine, that the right to use water is based on ownership of land without regard to the time of use or to any actual use at all, is still basic in the majority of states, but various modifications have been made by statute or court decisions in several states. Thus for surface water the riparian doctrine gives certain rights in the stream flow to the owners of land contiguous to a stream but limits them to a "reasonable" use and requires that the use be not injurious to other rights. For ground water under the American doctrine of reasonable use, each landowner is limited to a reasonable use of the water as against the others where there is a common supply; ${ }^{14}$ and under the California doctrine of correlative rights, not only must the use be reasonable, but the rights of all landowners are correlative, and where the supply is insufficient for all, each is accorded a "fair and just" proportion. ${ }^{15}$

Even with limitations as to reasonable use or beneficial use

13 United States $v$. Rio Grande Dam and Irrigation Co. (174 U.S. 690), 1899. 14 Basset v. Salisbury Mfg. Co. (43 N.H. 569, 82 Am.Dec. 179), 1862.

15 Katz v. Walkinshaw (141 Calif. 116, 74 Pac. 766), 1903. 
or prorata sharing, the landownership basis for water rights is likely to be unsatisfactory when or where the water resources are inadequate to meet the reasonable requirements of all landowners.

This is the situation in the arid regions where the water supplies are so limited in comparison with the land suitable for irrigation or for other beneficial uses of water that a prorata distribution to all landowners would lead to disaster for everyone. No state in the arid regions, therefore, subscribes exclusively to the common-law doctrines. In the humid regions, too, there are small areas where the "reasonable" needs of all landowners already exceed the available water supply or can exceed it in the near future. All the humid states, however, have surplus waters at some season of the year, which flow from those states in streams. These surpluses can serve to relieve local shortages and have been used for that purpose in many places.

WATER RIGHTS BASED ON PRIORITY OF USE. MOst of the states of the arid regions have repudiated the common-law doctrines in whole or in part by declaring water to be public property, in which rights are acquired by appropriation; that is, the first user of water acquires a priority to continue the use. It is obvious that this is diametrically opposed to the common-law doctrine, for the statutory doctrine of appropriation is based on the time of use and on actual use without regard to the ownership of the land where the water is appropriated. Nevertheless the "water law" in most of the 17 western states still embraces both doctrines to some extent. Only Utah and Nevada have declared appropriation to be the exclusive method for establishing rights to all water; Colorado, Idaho, and Oregon give preferential treatment to landowners in the case of certain springs, seepage, and waste waters but otherwise accept appropriation as the only means of establishing water rights; and in New Mexico it may be inferred that practically all ground water and surface water is subject to appropriation. In the other states some waters are subject to appropriation, and others are subject to rights gained by land ownership. 
As Hutchins points out," "No case has been found in which the courts have gone to the extent of holding that waters resulting from precipitation and still diffused over the ground are subject to exclusive appropriation as against the right of a landowner to intercept and utilize them while on his land. . . ." In general the appropriation statutes have not yet been construed by the respective state courts to the extent of defining the appropriative rights in water in each phase of the hydrologic cycle.

One may wonder how two diametrically opposed doctrines of water rights can exist side by side in the same state. That wonder is enhanced when it is realized that these doctrines are applied on the basis of an cmpirical classification of waters which in the light of present scientific knowledge is unsound. Some "classes" differentiate betwcen waters in disregard for their close hydrologic relationship, and others include waters of markedly contrasting hydrologic characteristics. Water rights established under a system so unsound hydrologically can be highly insecure.

The broad class of surface waters in watercourses has been defined by many courts in terms that are in general agreement except for minor variations to fit the particular case. As summarized by Hutchins, the class includes "water flowing continuously or intermittently in natural surface channels from definite sources of supply, and waters flowing through lakes, ponds, and marshes which are integral parts of a stream system." ${ }^{17}$ In several court decisions the intimate relation between the stream and the ground water adjacent to the channel has been acknowledged, and the ground water, known as the underflow, has been recognized as a component part of the stream system. Full recognition of the hydrologic unity of watercourses as defined on page 136, however, has commonly been impossible because of the established practice of treating surface waters and ground waters in separate categories. Real definition and protection of all water rights in watercourses

16 Hutchins, W. A., Selected Problems in the Law of Water Rights in the West, U.S. Dept. Agr. Misc. Pub. 418, p. 135, 1942.

17 Ibid., p. 7. 
requires delineation of the entire hydrologic unit involved and abandonment of the separate categories of rights.

If the present classification of "watercourses" in many instances cuts jaggedly through waters of a single hydrologic unit, the other principal class of surface waters goes to the opposite extreme. The surface waters not in watercourses, commonly grouped as "diffused surface waters," may include visible waters from a great variety of sources: standing water from precipitation which has not yet infiltrated into the ground or which cannot enter the ground because of impermeability of the surface layer; overland flows which may either seep into the ground elsewhere or enter a recognized "watercourse"; the discharge from ground-water reservoirs at springs or seeps; water in sloughs or escaped flood waters in "watercourses" that have been too narrowly delimited in their definition; marshes and bogs formed by ground water where the water table rises to the surface; waters discharged by streams into the closed basins of the llest, which will be dissipated eventually by evaporation. Here certainly is a hodgepodge class, necessitated doubtless by the meagerness of hydrologic knowledge in bygone days but eligible for retirement in the light of present knowledge.

The empirical classification of ground waters is still less workable than that for surface waters. Court decisions and statutes have commonly classified ground waters as (1) definite underground streams and (2) percolating waters. If the characteristics of "definite underground streams" include the turbulent flow that characterizes practically all surface streams, this class becomes a small one indeed, suitable only for cavernous limestones, some organic soils, and certain volcanic rocks. If on the other hand laminar flow through porous materials is included, the class will embrace all ground-water reservoirs as fast as the requirements of the word "definite" can be met by scientific investigation to delineate their boundaries. The class was drawn to be exclusive, however, for the burden of proof was placed upon the person who asserts that a "definite underground stream" exists. This was a very high wall 
to scale in the days when the "physical laws governing underground water and its subterranean progress" were considered to be "irregular and unknowable to any certainty," and when the water was "changeable and uncontrollable in character and subject to secret and incomprehensible influences." 18

"Percolating waters" were once defined as "vagrant, wandering drops moving by gravity in any and every direction along the lines of least resistance." ${ }^{19}$ Even today the common ideas concerning percolating waters seem to come from the operations of a common kitchen utensil, which simulates part of the hydrologic cycle by providing intermittent "precipitation," infiltration and percolation of water through coffec grounds, and in which the percolated water then loses its identity in the common pot. Some legal treatises have differentiated among percolating waters tributary to surface watercourses, springs, and to underground reservoirs; and "diffused percolations," which are evidently the "vagrant" waters, having no known destination. Artesian waters are sometimes distinguished from "percolating" waters, sometimes included as a subdivision of the class. In some states the appropriation doctrine governs in rights to ground water in "defined underground streams," or in artesian aquifers, but rights to "percolating" waters are inherent in land ownership under the common-law doctrine. Yet when the hydrology is investigated, it may well be shown that the "underground streams" or the artesian aquifers depend upon the "percolating water" for replenishment, or vice versa.

The tendency to consider ground water and surface water under separate categories, in statutes, in court decisions, in filing of water rights, may also lead to unsettling of established water rights. Rather generally in the western states the waters first used were from streams, and the oldest rights are therefore in the base flow of those streams-the flow sustained largely by ground water. Thus many surface-rater rights have

18 Kinney, C. S., A Treatise on the Law of Irrigation and Water Rights, vol. 2, p. 2115, quoting an early Vermont case.

19 City of Los Angeles v. Hunter (105 Pac. 755), 1909. 
higher priority than the rights to wells in the same basin. As shown in Chap. II, the natural priorities of the hydrologic cycle are just the opposite, and replenishment to ground-water reservoirs commonly takes precedence over maintenance of stream flow. To date relatively few conflicts have arisen between users of water from wells and from streams, and in most states it is still possible to administer water laws as if surface water and ground water were separate and independent resources. However, as more complete utilization of water resources is made in various areas, it is inevitable that complex problems will arise. These problems can be settled only by an adjudication of all water rights, based on full recognition of the physical principles governing the morement of water throughout the hydrologic cycle under natural conditions and on determination of the changes that have been effected by development.

INDIVIDUAL RIGHTS VERSUS PUBLIC RIGHTS IN EACH PHASE OF THE HYDROLOGIC CYCLE. In the states where waters have been dedicated to the public and made available for use by appropriation, each water user deserves a clear statement as to his rights in the water in each phase of the hydrologic cycle, both as an individual landowner and as a member of the public who appropriates the water to his use. No state has yet attempted to spell out the rights inherent in land ownership versus the rights developed by appropriation in all plases of the cycle.

As to precipitation, just a few years ago it would have been pointless to consider any legislation as to rights, because a landowner could be assured of getting all that was coning to him under natural conditions, regardless of statutes. But dry ice and silver iodide give promise now of diverting precipitation in transit, and it thus becomes important to the landowner to know his rights to precipitation without interference. Unfortunately we appear to be on the verge of learning how to interfere with the natural conditions hefore we have sufficient knowledge to say exactly what is the destination of water vapor in the atmosphere and what quantity will be discharged natu- 
rally, so that science cannot say who has been damaged by artificial "rain making."

The problems of "appropriation" of water vapor in transit are likely to be especially serious to some states. Colorado is a good example. As artificial rain making becomes efficient, it may be possible for the surrounding states to intercept the bulk of the water vapor moving toward Colorado. But that state has natural interceptors of precipitation in its towering mountain ranges, and these already produce strcam water for all the neighboring states via the North Platte to Wyoming, the South Platte to Ncbraska, the Arkansas to Kansas, the Rio Grande and San Juan to New Mexico and the Colorado to Utah, Arizona, Nevada, and California. If the precipitation is intercepted instead in these other states by artificial means, a question may well arise as to compacts that have specified the rights of adjacent states in water originating in Colorado.

Soil water seems rarely to have been a matter of controversy, and doubtless the landowner is generally considered to have a right to it as absolute as to the soil. But if that is the case, the states which have declared "all" water public property and subject to appropriation on a priority basis must hedge. Science can show conclusively that the ultimate source of practically all water supplies is precipitation, and in any sizable area a significant fraction of that supply has passed through soil somewhere. All appropriators of ground water are concerned therefore with what happens in the soil in the area that yields their supplies.

It is also known that the proportion of precipitation that runs off, infiltrates into the ground, or percolates into groundwater reservoirs can be modified significantly by land use. Full protection of rights to surface or ground water might therefore require supervision of all activities of landowners in the source areas of that water. But if the landowner has only subordinate right to the water that falls as precipitation on his property, the degree of that right should be stated with reference to his operations in the use of his land and protection of the soil against deterioration. 
The hydrologic cycle provides a logical basis for distinction of individual rights inherent in land ownership as against public rights subject to appropriation. In the precipitation and soil moisture phases the movement of water is chiefly vertical, but in the ground-water and surface-water phase horizontal movement dominates and the water crosses property lines.

In areas where the surface and ground waters have been declared public water, available for use on a first-come, firstserved basis, the relationship between ground water and surface water must be recognized, if the rights to each are to be placed on a firm basis. Part of this recognition will involve abandonment of the common fallacy that water is "lost" when it seeps from a stream into a ground-water reservoir and that it can be "saved" by preventing the seepage. The terminology is an anachronism from the days when little was known about ground water. Actually water "saved" by being held on the surface is subject to loss by evaporation, while the water that disappears into the ground is generally not subject to evaporation losses and is usually recoverable.

The return of water to the atmosphere by evapotranspiration is receiving more and more attention, because by reduction of natural losses increased quantities of water are available for man's use. The rate of evaporation has become a dominant factor in sclection of sites for reservoirs in arid regions, and in scveral western states cstimates of the undeveloped ground-water potential are being made on the basis of evidence as to the natural evapotranspiration in each locality. Such natural losses can be salvaged by various means. It should be possible to establish a right to such water by evidence that there had been natural waste and that the developed waters result entirely from reduction of that waste; such proof might well be more conclusive than an attempt to establish the adequacy of supply from some remote source area.

WATER RIGHTS BASED ON PREFERENTIAL USE. Existing and potential water users are entitled to know of any conditions, such as discriminations on the basis of type of use, which might 
subordinate their rights to others in periods of deficient supply, when the need for water is greatest.

The constitutions and statutes of many states grant various preferences in the use of water, which may take precedence over the priorities of established rights. Generally water for domestic and municipal use is accorded the highest preference, with use for irrigation, industry, mining. and power following in that order. Texas gives preference to industrial use over irrigation and adds use for navigation and for recreation at the bottom of the list. This preferential treatment operates in various ways in various states: it may be the basis for choosing between pending applications to appropriate water or for denying an application if it is deemed not to serve the public interest; it may permit municipalities to reserve water for their future expanded requirements or may permit condemnation of an existing use in favor of use with higher preference, with compensation; and in times of water deficiency the available water supplies may be restricted among the established rights on the basis of preferential use rather than priority of use.

Navigation is the superior use of the water of a navigable stream, based on the constitutional power of Congress to regulate interstate commerce. South Dakota has taken cognizance of this in a statute exempting its navigable waters from appropriation, but the importance of navigation to the arid states is perhaps better epitomized by the Texas statute which places navigation above "recreation and pleasure" but below all other uses of water in a list of preferences.

Congress in recent legislation has also accorded navigation a low priority in arid regions. Sections $1(b)$ of the Flood Control Act, approved December 22, 1944, and of the River and Harbor Act, approved March 2, 1945, provide that:

The use for navigation, in connection with the operation and maintenance of such works herein authorized for construction, of waters arising in states lying wholly or partly west of the 98th meridian shall be only such use as does not conflict with any beneficial consumptive use, present or future, in states lying wholly 
or partly west of the 98th meridian, of such waters for domestic, municipal, stock water, irrigation, mining, or industrial purposes.

If current plans for complete utilization of water resources in the arid regions are carried out, many streams that have been navigable will discharge ultimately only enough water to dispose of salts and other undesirable materials.

Since the flow of navigable streams is dependent on contributions from numerous non-navigable tributaries, practically all surface-water and ground-water developments in the drainage basin may have some effect upon the use of those streams for navigation. The constitutional priority of navigation is therefore likely to become a hot issue. It already has become so on the Missouri River. However, the interests of ground-water users so far have come into direct conflict with those of navigation only where navigation channels have been dredged dceply enough to cause salt-water encroachment into ground-water reservoirs (see pages 208-212).

RIGHTS AND RESPONSIBILITIES IN PHYSICAL AND CHEMIICAL Properties of water. As shown in Chap. V, only a small fraction of the water used by man is actually consumed in that use. For the rest only specific properties are used and the water is then retuned to ground-water or surface-water bodies, where it may be used again, perhaps several times. Many users depend to a considerable extent upon water already used by others, particularly along large rivers. The chemical or physical properties are commonly changed by each use, and the change is usually for the worse as far as downstream users are concerned. If water is used for sanitation, it becomes unsanitary; if it is used for washing, it gets dirty; if used for cooling, it gets hot; if used for irrigation or industrial processes, it becomes contaminated by soluble or suspended materials.

Used water has been the subject of many controversies and considerable legislation. As villain it has been the basis for a large body of court decisions and statutes regarding pollution on the one hand and concerning damage to real property on the other. Men have also fought for the right to use "re- 
turn" or "waste" water, with the result that in many western states such water may be appropriated, although the original user is generally under no obligation to continue the wasteful practices.

The statutes and court decisions regarding water that has been used have been developed to deal with a host of separate problems; there is great need for recognition and comprehensive analysis of the relationships of these problems of disposal to each other and to the problem of water use and water rights. For the most part little discrimination has yet been made by the public in discussing water, although all agree that it should be "usable." It is conceivable that water users will one day demand as their right not only a specified number of gallons of liquid but water with certain specified requirements as to chemical and physical quality. Any right to water of specific qualities would logically involve also an obligation to discharge unconsumed water meeting certain requirements as to quality.

RIGHTS AND RESPONSIBILITIES IN COST OF OBTAINING THE WATER. A water right is of no value if the water can be obtained only at prohibitive cost. For certain regions cconomic conditions may be such that the utilization of the water resources must be considerably less than the full potential. As stated by Hutchins: ${ }^{20}$

The economic feasibility is as important as engineering feasibility. The ground-water supply in a given case might be adequate for irrigation of all overlying land if lifted 400 feet, but the value of crops which it is possible to produce on that land may be far too low to justify the cost of pumping with such a lift. Economic feasibility in that area may depend upon the use of only the water available at less depths.

Wherever it is economically feasible to develop a certain quantity of water for use in a specified area, it is commonly true that the first water appropriated is the most accessible and least expensive, and as more water is developed the cost

20 Hutchins, op. cit., p. 177. 
increases: in the case of surface water because of the expense of construction of larger dams and transportation of water over increasing distances; for ground water because of the greater depth from which water must be pumped. The interests of the community or state in making the fullest practicable use of its water resources are in conflict with those of early appropriators, if the increasing development puts them to greater expense in obtaining their water. It is desirable that the water law state to what extent each water user is protected in his "means of diversion" and to what extent he is expected to share the increasing cost of developed waters.

According to Hutchins, ${ }^{21}$ "The English or common-law rule governing ownership of percolating water does not protect the landowner from a lowering of the water level under his land resulting from his neighbor's operations." In states where water rights are governed by the appropriation doctrine, the situation is not so clearly defined. Fairly recent cases in four states (Arizona, California, Colorado, and Idaho) involve the rights of an appropriator of ground water when the water level in his well is lowered by operations of subsequent appropriators, with decisions in favor of the prior appropriator. In the Flowell area in Utah, additional appropriations of ground water were prohibited for many years by administrative action in order to ensure the continuance of artesian flow from existing wells. ${ }^{22}$

Rather generally appropriators of ground water feel that they are entitled to damages if they are forced to additional expense in obtaining their water because of the operations of subsequent appropriators, but this idea has been sharply criticized by several scientists on the ground that it will seriously curtail the fullest utilization of the ground-water supply. Thompson and Fiedler write: ${ }^{23}$

21 Hutchins, op. cit., pp. 168-182.

22 Dennis, P. E., G. B. Maxey, and H. E. Thomas, Ground Water in Pavant Valley, Utah, Utah State Engr. Tech. Pub. 3, 1946, 96 pp.

${ }_{23}$ Thompson D. G., and A. G. Fiedler, Some Problems Relating to Legal Control of Use of Ground Waters, Jour. Am. Water Works Assoc., vol. 30, p. 107, 1938. 
Carried to an ultimate conclusion, these decisions might mean that in many areas the first appropriator could require damages from every subsequent appropriator and each subsequent appropriator, in turn of priority, could require damages from all later appropriators, until the last one would have to pay tribute to all. If the doctrine of appropriation is to accomplish the desired end of making full use of the ground-water resources of the state, it must be recognized that some lowering of the water table or of the artesian pressure is a reasonable result of a reasonable method of diversion (pumping) of the water, and should not constitute a basis for damages.

More recently it has been stated: ${ }^{24}$

If future decisions should hold that rights to divert and use water from ground-water bodics include the right to maintenance of the elevation of the water in the wells through which such water is diverted, it would be a severe blow to the interest of conservation and highest utilization of such supplies. There is a great need for clarification of this phase of ground-water law.

In a recent decision of the Utah Supreme Court ${ }^{25}$ the prior appropriator was denied redress for loss of artesian pressure caused by the operations of a subsequent appropriator. The remarks of Justice Wolfe, concurring in the decision but offering a sounder hydrologic basis for that decision, are quoted:

I do not think we should hold, in view of our orerarching water policy, that at this stage of our knowledge of the distribution and inventory of underground water resources prior users gain a vested right in a means of diversion of water. This must be left flexible. . . Prior appropriators by first tapping the basin might reap the benefit of a static head sufficient to bring the water diverted to the surface, but to require all subsequent appropriators to preserve this means of bringing the water to the surface would be to require them to preserve the static head, and thereby prevent the widest use of that underground water, or introduce impractical problems of allocating among numerous subsequent ap-

24 Baker, D. M., Discussion of Tolman and Stipp's "Analysis of Legal Concepts of Subflow ....," Proc. Am. Soc. Civil Eng., vol. 66, p. 380, 1940.

25 Hansen v. Salt Lake City (205 Pac. 2d sec. 255), 1948. 
propriators the amount of impairment each caused to the static head of a prior user of users. ... I desire tentatively to express the view that the point of diversion is not at the surface where the water either by its own static head or by artificial means emerges, but at the point or points where the appropriator takes it from the underground source. I have doubt as to whether an appropriator of underground water appropriates static pressure or head as a concomitant of the water he appropriates, even when he appropriated by diligence before the statutory method was in force.

INTERRELATIONSHIP OF SUBDIVISIONS OF MAJOR DRAINAGE BASINS

In the early stages of water development it is possible to treat various subdivisions of a drainage basin as separate and independent units, even when the units obviously are dependent upon a common source of water. As the separate areas approach full utilization of available supplies, however, their interdependence becomes more and more apparent and the need for establishing the rights as between areas grows greater. The lack of adequate hydrologic data has hampered or delayed such determinations in many areas where water problems have become acute, but even where there is a substantial volume of data the problem is likely to be complex. The water rights of individuals in the separate areas are especially difficult to adjudicate if the areas are in different states and subject to different water laws or doctrines. Economics may be a major factor, bringing in arguments as to the relative cost of necessary development and the relative value of the water in various areas.

Interstate streams have produced the most difficult problems to date, where utilization of water in one state is dependent upon flow from source areas beyond the jurisdiction of that state. The problems dealing with water not yet developed and utilized are particularly difficult to solve, for they bring up the question of the respective claims of source areas and of the areas lower in the drainage basin. The states, which are the arbiters of most water disputes, become protagonists 
in these larger conflicts and may show remarkable inconsistency in their policy. For instance, California in her "Counties of Origin" act pertaining specifically to the Central Valley ${ }^{20}$ has established the policy of reserving certain rights for the counties in which the water originates and permits others to appropriate only the waters that are surplus to the contemplated needs of the counties of origin; but has advanced contrasting arguments in her assertion of rights in the water of the Colorado River, of which a negligible amount originates within California.

As Hutchins has pointed out, ${ }^{27}$ each state is entitled to an equitable apportionment of benefits from the use of an interstate stream, and some states have resorted to compacts for the adjustments of conflicting interests. The United States Supreme Court ${ }^{28}$ has established certain principles applicable to the apportionment of interstate water, among which are the following: ${ }^{29}$

1. Each state is entitled only to an equitable share of the water of an interstate stream, and an adjudication decree in one state cannot confer water rights in excess of its share.

2. Adjustment of rights in controversy may be made by compact as well as by a suit in the Supreme Court, which recommends the compact method to avoid litigation.

3. Whether made by compact or Supreme Court decision, the apportionment is binding on the citizens of each state and on all claimants of water rights.

4. The apportionment may provide either for a continuous division of water or for rotation in use of the stream.

5. No claimant has any right greater than the equitable share to which the state is entitled, so that no claim can be

26 Water Code of the State of California, Sec. 11460.

27 Hutchins, op. cit. pp. 407-413.

28 Hinterlider v. LaPlata River and Cherry Creek Ditch Co. (304 U.S. 92), 1938.

29 Hutchins, op. cit., pp. 412-413. 
made that a vested right is taken away by the apportionment, if the compact is otherwise upheld.

In conflicts of smaller dimension, involving perhaps communities within a single state or even a single county, the present structure of water rights may be so intricate and complex as to inhibit full utilization of the available water resources. Here, too, a practical solution may be found by collective bargaining that leads to agreements analogous to interstate compacts.

Compacts characteristically have been concerned primarily with quantities of water. The quality of the water should also be a significant element, especially for the downstream users, since the upstream use contemplated in the compact must inevitably cause some deterioration in the quality. On the other hand, if the deterioration is too great, the water will not be suitable for its intended use downstream.

Problems of interstate allocation of ground water have not been important so far, but they are bound to arise in the future as there is increasing development of ground water from aquifers that cross state lines, particularly the ground water of interstate watercourses.

\section{PROBLEMS OF REGULATING GROUND WATER}

The critical problems resulting from the increased utilization of ground water in the past 20 years have given impetus in many states to legislation for control of ground-water development. Most of the western states now have statutes declaring ground water subject to appropriation, although some statutes refer only to certain "classes" of ground water or to certain areas within the state. The control of ground-water development in most of these states is based upon scientific investigations to determine the capabilities for natural replenishment of individual ground-water reservoirs, and the total appropriations are limited to that amount. Several eastern states also have subjected ground water to regulation in certain 
designated areas, on the basis of the state's police porrer rather than a declaration of public ownership of the water.

In the areas where these critical problems have been solved, it has generally been possible to reach the solution without reducing the draft for beneficial use-by reducing waste from wells, or prohibiting further increase in draft, or reclaiming used water, or replenishing aquifers artificially, or tapping new and undeveloped water resources. The best-known instances of actual reduction in draft have been in areas where water rights are based on the doctrine of correlative rights, which provides for apportionment where water supplies are not sufficient for all (see pages 60-61).

The regulation of ground-water draft where rights are based on appropriation is by no means so simple as the regulation of surface-water diversions in order of priority. At each stage of the stream there is water for just so many appropriators and obviously none for those with junior rights. By reason of the large storage in most ground-water reservoirs (perhaps accumulated over a period of many centuries), there generally is water for junior appropriators, even when the draft by senior appropriators is exceeding the rate of replenishment.

It is possible to utilize ground-water storage like a constructed reservoir on a stream, to give a large number of appropriators fairly constant quantities from year to year, in which case the junior appropriator's right is essentially equal to that of his seniors', as long as the long-term total draft does not exceed the average replenishment. For effective regulation on this basis, it is essential to know the capacity for sustained yield, commonly called the "safe yield."

"SAFE YIELD." This term, originated by hydrologists, may well prove awkward for them because of the variety of interpretations possible. "Safe yield" is an Alice-in-Wonderland term which means whatever its user chooses. Several definitions have been proposed by hydrologists, some of which are concerned only with hydrologic conditions while others are tied also to economic conditions. But if written into statutes or 
considered by the courts without the reservations of the technician when he uses the term, confusion is almost certain to result, because the "safe yield" will vary widely depending upon the stipulations that govern the determination.

In a ground-water reservoir where the water is unconfined in certain areas (the recharge areas) and under artesian pressure in other places, the safe yield will be a certain quantity if it is specified that all withdrawals must be by flow from artesian wells, a larger quantity if it is permissible to pump water from depths as great as 50 feet, and still more if allowable pumping lifts are as much as 500 feet. But the safe yield will vary also depending upon the locations of wells and the type of wells constructed. Assuming that the well construction and spacing of individual wells are suitable for maximum recovery of water, the safe yield will be a certain quantity if all wells are 40 miles from the recharge area, considerably greater if they are about 10 miles away, and still more if they are adjacent to or within the recharge area.

The development of ground water may alter the natural conditions greatly enough to produce a significant modification in the safe yield computed on the basis of those natural conditions. In an area with water table so high that recharge from precipitation is rejected periodically, the ground-water replenishment may be increased materially after the water table is lowered by pumping. Especially along watercourses, when water levels in wells are lowered below river level by pumping, infiltration may be induced from the river so that the safe yield includes contributions from a source that may have been no factor under natural conditions. ${ }^{30}$

Quality of water is an important consideration in several ground-water reservoirs near the coasts or adjacent to brinebearing rocks, and the conclusions as to safe yield must vary with the limitations as to chemical constituents in usable water.

so Charles, J. R., Discussion of "Utilization of Ground-water Storage in Stream System Development," Trans. Am. Soc. Civil Eng, vol. 111, pp. 319$326,1946$. 
From the hydrologic viewpoint the safe yield should be presented as a "family of curves" rather than' as a single quantity, to show the relation of safe yield to pumping lift, well construction, well locations, and modifications that would result from induced recharge from precipitation or streams or unusable water. This information can be obtained only in broad, general terms prior to development. Revisions are necessary to fit the circumstances as development proceeds toward complete utilization of the perennial water supply.

Economic considerations are a separate problem, of major concern to the water user, since his purse is involved, and to his water department or consulting engineer or attorney. The hydrologist is likely to be out on a limb if he tries to include them in his evaluation of "safe yield."

The laudable efforts to develop ground-water reservoirs without exceeding the "safe yield" will almost certainly be more difficult than most people realize. The essence of development is to divert ground water that under natural conditions would be discharged into streams or into the atmosphere, and a well does this by making a depression into which the water will flow rather than continue on its natural way. It is basic therefore that water levels must be lowered and some water must be pumped from storage. When development is complete, the average inflow to this depression formed by the wells should be equivalent to the average draft. But in the course of the development of this depression, a substantial volume of water has been mined, and as a result the pumpage may have been considerably greater than the sustained yield.

Many hydrologists after studying specific areas have recommended "slow, orderly development," which would lessen the sharpness of the change from the mining economy of development to the smaller quantity of perennial supply. But when the basin is fully developed, there may be less water than required for rights established during the development, unless provision can be made for artificial replenishment to supplement the natural "safe yield." 
Estimates of safe yield have sometimes been made for small portions of ground-water reservoirs, in some cases for individual well fields, and these are of value in operation of those wells. For effective regulation of ground-water development, however, a comprehensive evaluation of the entire hydrologic unit is essential, in order to embrace all the facilities for natural recharge, movement, and discharge of water within the aquifer, as well as the extent to which development can change those natural conditions.

RESERVOIRS WITH NEGLigible REPLENishMient. Some groundwater reservoirs have a vast amount of water stored in them but nevertheless have a very low safe yield, because of negligible replenishment (see pages 41-47). Regardless of the doctrine under which rights are established in the water of those reservoirs, any rights on a perennial basis must be restricted to the very low safe yield.

The vast quantity in storage in the reservoir must be regarded as a nonrenewable resource. Its withdrawal is equivalent to the development of such resources as petroleum, coal, or metals, and rights cannot be on more than a temporary basis, perhaps specifying a certain total quantity rather than a certain quantity per year. The question for the state concerned is whether the "mining" of the stored water in this generation is socially and economically desirable or whether it should be handed down untouched to future generations, who must then make the same decision.

Within a single ground-water reservoir there are commonly some places where the yield is limited by the rate at which water can flow from distant recharge areas, rather than by insufficient recharge. A problem in regulation here involves the question as to what extent the water user should be protected in his selection of a site for wells to develop that water.

EFFECT OF REgULATION UPON PRESENT DEVELOPMENT. The states of heaviest ground-water development have achieved their eminence in the absence of any regulation. California, Arizona, Texas, Louisiana, and Arkansas lead the nation in quantity of water pumped from wells. California alone pumps 
about 40 per cent of the national total, and the five states together account for more than 65 per cent of the water withdrawn from wells throughout the nation. In none of these states was there any statutory basis for control of ground-water development during the construction of the hundreds of thousands of wells that produce this water, although Arizona's 1948 statute is designed to prevent further increase in draft in "critical areas." The colossal draft is chiefly for irrigation.

The lack of regulation shows up in the fact that these five states contain the great majority of the ground-water reservoirs where the annual pumping is significantly in excess of the average annual replenishment (Plate II). The situation is far from hopeless in many of those areas, however. Corrective measures are being taken in several places, notably in California, as pointed out on pages 60-77. It is expected that these corrective measures will bring replenishment into balance with the draft, in some places at considerable cost, but with substantial benefits to those areas where it has been possible to increase the natural perennial yield by artificial means. The success of these corrective measures has been possible, however, because of the finding of additional potential in stream flow or reclaimed servage or industrial wastes, or in areas from which water could be imported. Without such untapped resources and without regulation of pumping, there is no means of preventing a continuation of overdraft until the ground-water reservoir is exhausted.

There are several reasons for the lesser degree of groundwater development under the statutory regulations of other western states. Some states do not have the potentialities of a California or a Texas, and the quantity of water pumped even when all their ground-water reservoirs are fully developed will not be large. In several states additional ground water is known to be available for development, but it has not yet been applied for. There is little evidence that the statutes themselves have been responsible for limitation of development, because they generally have been broadly framed for the purpose of providing an orderly development in the 
interests of best utilization of the ground-water resources, and the administrative officials have been qualified technical men who know well the importance of water to their states. On the basis of sound technical data, they have done much to encourage sound development and to modify the pattern of development in the interest of greater utilization, restricting development only where studies show no other solution. However, in some areas restrictions have put a temporary brake on the rate of development until scientific studies can show whether there is ground water still unappropriated.

Strong arguments have been advanced against ground-water legislation, on the principle that it would hamper development and, since there are still large undeveloped ground-water resources in many parts of the country, that the legislation would result in economic loss. It is undeniable that groundwater development can be held to a level far below the potentialities of a region by rigid protection of established rights. Protection of rights to spring or to stream flow in some areas can be achieved only by prohibition of development of ground water. And regulations seeking to stabilize water levels at any particular position will generally prevent full utilization of ground-water reservoirs.

On the other hand, the proponents of ground-water legislation foresee great economic loss if excessive pumping is permitted to continue until ground-water reservoirs are emptied or contaminated by saline waters. For the country as a whole, intelligent water-resource development cannot be made except within a framework of law that will permit achieving the desired objective and prevent activities that would defeat the purpose of the development. As already mentioned, the legislation to date has generally succeeded in providing a means of controlling and yet not restricting development except in areas where pumping is approaching the "safe yield."

In many places the utilization of surface water and ground water has developed in a happenstance pattern that is far from the most effective use of the available resources, and the established water rights serve only to perpetuate this inefficiency. 
Many oil fields and mining districts had the same pattern of disorganized development in early stages, and effective development of those natural resources depended upon consolidation of a large number of individual holdings and extraction based on sound scientific principles. In the same way, the water resources might best be developed within recognized hydrologic units by water utilities or districts formed by agreement among the holders of established rights and having exclusive responsibility for furnishing water for all requirements. In some areas such a community organization may be the only effective means of realizing the full potential yield of the available water resources and of supplementing the natural yield by artificial recharge or by reclaiming waste water.

Permissive legislation for organization of such water districts by agreement of water users and other property owners might provide opportunities for further development of water resources under local autonomy, where existing water rights now place a definite ceiling on development. New Mexico has recognized the desirability for community action in a statute that provides for the formation of conservancy districts with the broad power to take any necessary step to safeguard their water supplies; several other states have similar laws. The formation of a district for efficient management of available water resources, in which all established water rights have been arbitrated and pooled, would be far more difficult but highly desirable in some areas.

\section{Water-conservation Practices}

Many practices serve to increase the quantity of water available for use and are at the same time beneficial - or at least not detrimental-to the conservation of other natural resources. These practices include those that promote economy in water use, or maintain the usability of water, or store water in reservoirs from times of surplus until it is needed. Almost invariably these practices involve cost in equipment, labor, or time to the water user or to the public. Such water-conserva- 
tion practices are far from universal. Apart from the question of cost, there are many areas, of course, where some conservation measures are not justified because supplies are still sufficiently abundant.

Temporary water shortages in various areas have shown that much water can be saved by economy in use. In New York City the usage of water was cut 25 per cent in late 1949 by such measures as repairing leaky pipes and fixtures, turning off faucets when not needed, and other economy measures, some of which caused hardships to certain water users and were enforced only for the period of emergency. Many of these economies, however, are habitually practiced in places where water is perennially in short supply. For example, there are statutes in many western states prohibiting waste of water from flowing wells. In most of these states beneficial use is the basis of all water rights. Nevertheless, even in the most arid states there are opportunities for further conservation of water merely by economy in use. Efficient techniques in irrigation can conserve water and also prevent waterlogging and leaching of soils; but in many places such techniques are still not the rule. Many industrial plants have achieved great economies in use of water, and thus have demonstrated the possibilities of water conservation by industrial users where necessary.

Similarly, there is a wide variety of conservation practices that maintain the quality of water. Some prevent natural waters from contaminating usable supplies, for instance, the construction of wells to prevent entry of brines, or the ponding of brine springs to prevent their flow into streams. In ground-water reservoirs where there is danger of salt-water intrusion, pumping may be limited to protect the supply. In general, preventing or controlling pollution in lakes, streams, and coastal waters maintains the uscfulness of these water sources, not only for our needs but for fish and wildlife.

Storing water in reservoirs when there are surpluses from precipitation is, of course, generally practiced. Arguments have developed, however, as to the relative merits of the vari- 
ous kinds of reservoirs that can be used to store these surpluses: the soil, ground-water reservoirs, lakes, artificial reservoirs in headwater areas or along major watercourses. Balanced conservation of water resources will depend on all these rather than emphasizing one to the neglect of others. In each locality the methods of storage should be determined on the basis of adequate fundamental data as to natural facilities for storage, and by mature consideration of the social and economic values to be won by conserving water and other resources.

After a method of storage has been selected, the management of the water resources developed may be an issue among users because of the various, sometimes conflicting, uses to which the water may be put. In the San Joaquin Valley in California, for example, the question of who shall receive the benefit of artificial storage underground is being argued. Rescrvoirs constructed along streams can hardly serve the needs of all with equal satisfaction. For flood protection they should be empty most of the time, ready to store the surplus water of flood stages and thus prevent damage downstream; but recreational needs are best served if the reservoir is kept full. Municipal, industrial, and power needs require a fairly steady outflow from the reservoir, while for irrigation the draft on the reservoir is seasonal. For navigation the outflow from the reservoir must continue down the channel, but for irrigation it will be diverted elsewhere. The multiple-purpose reservoir, designed to meet several and sometimes all of these conflicting requirements, may be equivalent to half a dozen reservoirs assembled at a single site. In many instances it is more economical and effective than single-purpose development, but the conflicting interests may require compromise arrangements which do not serve all needs equally well.

\section{Public Enlightenment}

For most citizens water is only one of the essentials to life, albeit an indispensable one, and they have no more intention 
of concerning themselves with the details of water supply than they have of fixing their cars or television sets in time of trouble. An appreciation of the broader aspects of water resources is important to them, however, particularly if their activities are concerned with any processes that use significant quantities of water. Some understanding of the possibilities and limitations of regional resources of both surface water and ground water can aid in the selection of a site for industrial plant or irrigated farm and can encourage the recognition of water supply as one of the basic factors in designing a plant or working out industrial techniques.

Few textbooks deal comprehensively with ground water. Educational institutions generally cover the subject only to the extent of including a chapter on ground water in a course on geologic processes, a short discussion of ground-water hydraulics in civil-engineering courses, or a statement of the classification of water and a study of court decisions as part of a course in law. Much of the public enlightenment now depends on the writings of nontechnical men, and they betray a general lack of understanding of the fundamental principles of occurrence of water beneath the earth's surface. This lack of understanding appears even in the writings of technical men in related fields of scientific study, including experts on other phases of the hydrologic cycle.

Many writers have the impression that ground water remains stagnant beneath the surface waiting for man to pump it out, unless some neighbor drains it out by pumping from his well. Actually the replenishable ground-water supplies are characteristically in motion, and any water that has remained in one place for a long period, such as connate water, is likely to be too saline for use. The hydrologists themselves are perhaps responsible for further confounding the nontechnical writer, for in describing the hydrologic cycle they have used oversimplified diagrams, which may have given rise to the common concept of a single huge "ground-water reservoir" extending across the Nation and susceptible to replenishment from precipitation at any point. Scientific work to date has 
shown that the reservoirs yielding the great bulk of the Nation's well water are replenished in areas which in the aggregate would be only a minor fraction of the total area of the country.

A few fundamental facts, outlined in the following paragraphs, can aid materially in giving the public an appreciation of the possibilities and complexities of effective management of ground-water resources.

\section{SIGNIFICANCE OF “WATER-TABLE" FLUCTUATIONS}

The decline of "water tables" (including piezometric surfaces of confined aquifers) has been heralded widely, and many writers have made dire predictions for the future on the basis of data collected in various localities where these declines have occurred. There is need in all analyses of the national groundwater situation to realize the great variety of reasons for the measured declines in water levels.

Declining water levels are inevitable if water is taken from a well, and if the draft is increased the water levels will decline further, whether the increase is obtained by drawing more water from one well or by drawing from more wells. If the creation of this depression results in diversion of water from seeps or other points of natural discharge, the draft may be sustained perennially. The declines might then be viewed with pride, as evidence that the community has not left its talents buried in the ground but has put them to some use. The decline in "water table" may be as much an indication of progress as the carloadings of agricultural or industrial products shipped from the community.

A declining "water table" is also characteristic of the region that has used its water resources not wisely but too well and is taking far more from its ground-water reservoir than is replaced naturally. In such a region the reservoir will eventually be emptied unless pumping is reduced or unless some means can be found to put more water into that reservoir than is done by nature. Superficially the records in such an area are the same as those in developed areas where the pumping does not 
exceed the safe yield-water levels have been lowered since the first well was constructed-and discrimination must be made on the basis of an adequate scientific study.

The public should know also that man is not responsible for all the fluctuations in "water tables," for precipitation is the prime source of replenishment for all water resources, and climatic variations have a profound effect upon the position of the water table. Throughout most of the Nation the precipitation was far below normal in several years of the 1930's, particularly 1931 and 1934, and large areas experienced severe drought. Records collected in that decade showed the water table in large areas to have been several feet lower than in earlier years. Those records are still being quoted in books and articles published during the last two or three years, although subsequent records in the same areas show that water levels generally have risen appreciably since the end of the drought.

\section{POSSIBILITIES OF MULTIPLE USE OF IVATER}

The public is aware that the nation uses prodigious quantities of water; it should also know that most of that water is not used up but remains a part of the water supplies upon or beneath the land surface and may be available for further use. These once-used waters create problems of contamination, and largely because of them some rivers are not sought out for additional water supplies, even though they may carry an adequate volume of liquid. The serious pollution of such rivers as the Delaware, Potomac, Hudson, Ohio, and New England streams has led to organization of interstate commissions, which have already initiated major programs for correction. The possibilities of reclamation of sewage and industrial waste water are being considered in many localities where water supplies are limited, the reclaimed water to return to streams or to ground-water reservoirs.

There have been predictions that the Nation's great water requirements must some day, perhaps within 25 years, force us to obtain fresh water by distillation of the ocean. There is 
no question that this can be done, and there are some deserts close enough to the California coast to make it reasonable to consider augmenting their meager natural water supplies in this way. But in general the purification of sea water, containing the soluble wastes from the continents through several geologic ages, is a more formidable job than the cleaning up of water supplies available on the continent, which have been contaminated largely by our use.

The relative scarcity of water in some areas has led many industries to develop techniques which permit use of small quantities of water over and over again, rather than large quantities of water once. By recirculation some large users have been able to cut their needs for "new" water to as little as 5 or 10 per cent of the quantities used in similar industrial operations in other areas. In some states multiple use of ground water is effected by regulations requiring the return of water after use to the ground-water reservoir via diffusion wells.

POSSIBILITIES OF MANIPULATION OF STORAGE IN GROUND-

WATER RESERVOIRS

It should be evident to all that surface reservoirs would be useless for most purposes if they were maintained at constant level. A constant level would indeed provide an attractive lake for recreational purposes, where the shores could be lined with cabins and docks and where an unsightly mud bottom would never be exposed. But such controls would negate all other purposes for which a reservoir might be constructed, because the water flowing from it must then be equal to the inflow, and there could be no storage of water from times of excess to times of need. Thus a reservoir held at constant level would be of little value for municipal or industrial use, power, irrigation, navigation (except on the reservoir), or flood control.

The same conditions apply to ground-water reservoirs. They receive their greatest replenishment when precipitation and stream flow are most abundant, and least in times of drought. But if storage were held at a relatively constant quantity (by prohibition of pumping below a certain level), water would 
be pumped out chiefly when precipitation and stream flow are above normal, and therefore when most water users need it least. Conversely in times of drought less water would be available when farmers and cities need water most. Thus a ground-water reservoir is not being used effectively if its operation is on the basis of a balance each year between recharge and discharge. If the balance is achieved during a climatic cycle of several years' duration, however, the ground-water reservoir can provide holdover storage from wet years for the drier years when the need for water is greatest.

Experiments in artificial recharge of ground-water reservoirs have been successful in many places, and the techniques have been used by numerous industrial plants and agricultural areas to increase their available perennial water supply substantially. In view of the proved economic possibility of artificial recharge in many areas, the dependence upon natural replenishment may be considered a limited objective, to which the public should resign itself only if there are no unappropriated waters available for artificial recharge or if no feasible method of artificial recharge can be devised. In many regions there are opportunities for man to store water underground for use when needed, with minimum loss by evapora tion.

It does not follow that all ground-water problems will be solved by putting water underground everywhere. Over most of the Nation's area such practices would have no direct effect upon the more productive ground-water reservoirs. Artificial recharge can be deemed successful only if it augments the storage in a ground-water reservoir where it can be used, and therefore a knowledge of the hydrologic characteristics of that reservoir is prerequisite.

The problems of flood control are related to those of artificial recharge of ground-water reservoirs, for floods commonly provide the surplus waters needed for the artificial recharge. Along many of the rivers subject to damaging floods there are ground-water reservoirs of large capacity, in some cases large enough to hold more water than the river discharges in a year. 
Generally these ground-water reservoirs are recharged during floods and then drain out slowly, so that even under natural conditions they are of value in flood control. If water were pumped out of them, the recharge during floods might well be greater and their value in flood control enhanced. The possibilities of manipulating the storage in these ground-water reservoirs as an element in flood control have not been thoroughly explored, although notable achievements in coordination of flood control and ground-water recharge programs have been made by several state and county agencies.

\section{RECOGNITION OF WATER RESOURCES AS A VITAL FACTOR}

IN ECONOMICS

Although many of the enterprises of civilization have just grown haphazardly, there are some industrial plants, residential areas, even cities on sites that were selected after a thorough study of transportation facilities, labor market, accessibility to raw materials and to consumers, climate, tax rates, or other economic factors. In the past the water resources have not generally been considered among these factors, particularly in the humid regions where water supplies were abundant. In recent years, however, enough areas have been confronted by water shortages that water has assumed real significance as a factor in economic planning, whether by an industrial firm, a municipality, or a state or Federal governmental agency. Eastern firms contemplating branch plants in the West soon acquire a whole dossier on water supplies, regulations, and rights. And even in the most humid states a large user of water must be assured of adequate supplies before selecting a site for operations.

Many communities are already using practically all the water resolirces available locally and some have tapped the resources of surrounding areas in order to meet their progressively increasing needs. A few areas are finding no untapped water resources within economic reach, and they must of necessity get along with what they have. To them it becomes very important to make the most use of the limited water resources 
276 CONSERVATION OF GROUND WATER available, by reclamation and reuse of water wherever possible. To them, also, economy of water use is of major concern. Industrial and agricultural techniques economical in use of water are essential where water supplies are limited, even though the cost of installation may be considerably higher than that for equipment extravagant in water use. 


\section{Chapter VII}

\section{BETTER GROUND-WATER MANAGEMENT}

The environments we have encountered in developing ground water in this country are of great variety, and in the course of his survey Dr. Thomas emphasizes that the special characteristics of each one must be appreciated. To oversimplify ground-water problems, as is sometimes done when public support is sought for conservation measures, in the long run will not promote the development and conservation of this resource to maximum advantage. Varying factors of climate, topography, bedrock and surface geology, hydrology, and vegetation will all figure in programs for the control of ground water.

Unfortunately, it is true that much fundamental research into these factors, in which the hydrologist, the agronomist and the forester, and other specialists must collaborate, still remains to be done. Such collaboration is called for not only on specific research projects where the relation of land use to ground water is direct. The implication of our experience is broader. It is that, in general, land management and waterresource planning are closely interrelated, because the resources concerned are themselves related to one another in a dependent fashion.

At the same time it may be said that a popular assumption -that all that is required in land and water management is indiscriminate covering of land surfaces by forest and cropswill not necessarily result in greatest conservation values. In certain relatively arid areas, for example, nonbeneficial vegetation extracts large quantities of water which would other- 
wise contribute to ground-water supplies. The U.S. Geological Survey estimates that in Nevada and Arizona this natural waste is roughly about 3 million acre-feet a year, and that careful removal of such vegetation in these two states would probably salvage about 1.3 million acre-fect. In the 17 western states, salvaging half the annual waste (estimated at 20 to 25 million acre-feet) by nonbeneficial plants would provide water to a depth of 3 feet for some 1.7 million acres. Such clearing operations would be methods of land management aimed chiefly at increasing water yields.

Another example of the potentially competitive relation of certain uses of the land to water development is: over extensive areas in the United States major increases in soil water to recapture land values could only be accomplished at the expense of recharge to ground water used for other and competitive purposes. Put simply, in such areas there is no more water than there is, and conflicts over various uses of the available water and of land are inevitable. With the varying interests of the public, it is not surprising that where water is in short supply, as in the West, almost every water use has created an issue. Legislative action and court decisions have been required to settle suits between users of water for irrigation, industry, public supply, power, and fish and wildlife.

That these competitive relationships and other conflicts exist does not mean, however, that the conservation of ground water and of other resources for our own and future generations is an impossible task. Nor, as Dr. Thomas has shown in many examples, does conserving ground water imply storing away this resource for some remote nonuse. On the contrary, a conservation program, in providing for the planned management and wise use of nature's resources, obviously must take into accoun $\iota$ the realities and demands of day-to-day living. With a growing population the emphasis in our country necessarily has been on developing our resources. Our concern, therefore, should be to achieve sufficient foresight and control over this development, so that it may proceed wisely.

Where the total supply of the water is relatively constant, 
the challenge of the future lies in adequate management running parallel with wise use. Any policy which leads to unnecessary curtailment of legitimate use is bound to succumb, and should succumb, to the pressures of reality.

Some believe that temporary excessive use of a water resource is even warranted where a section of the country is being rapidly developed and major long-range expenditures for a wiser permanent use are unavailable during the period of maximum rapid growth. This position, for example, has been stated by the Metropolitan Water Board of Southern California, in commenting upon the excessive ground-water usage in this area in the past half century of rapid growth. The excessive use, the Board reflects, perhaps even made the growth possible, while it simultaneously brought on longrange development programs and, of course, certain temporary and even permanent penalties in ground-water depletion.

Where resources are plentiful, wise management usually is not easy to provide. A distinguished statesman from one of the Mediterranean countries once pointed out that he would not study a rich country in order to determine sound conservation practice. Where water is scarce, conservation dominates. Many years ago Benjamin Franklin paraphrased this axiom in the words, "When the well is dry then we know the worth of water."

One of the favorable factors in the conservation of ground water is that it is a renewable resource for which certain guiding principles of management are easily understood, although not so easily enforced. The difficulty arises whenever one attempts to translate a guiding scientific principle into an effective administrative mechanism. This is particularly true in coordinating the use of several renewable resources. To achieve their balanced conservation the administrator may be confronted with the necessity of expanding the use of one resource in order to maintain another. Such administrative decisions on the relative importance of one step versus another are not always purely theoretical in nature and inevitably lead to competitive struggle geographically and function- 
ally. The perfect syllogism of land and water management is neither easy to define nor likely to be practiced, because the forces involved, both human and material, are so complex that they do not lend themselves to precise calculation and adjustment.

No two ground-water situations are exactly alike. Usually they differ greatly with respect to the underground reservoirs and the percolation of ground water. A ground-water reservoir is dynamic rather than static in character. Its water is in flow even though at a slow rate, and the storage available may have come from yesterday's precipitation or from that rain which fell a hundred or more years ago.

In each area the citizen is confronted, therefore, with a different problem in which many rather than one circumstance control wise management. A grand generalization as to what should be done in ground-water management is probably impossible to make. This does not mean that certain important and universal guiding principles may not be applied. It is important for the reader to bear in mind, however, that generalizations inevitably and invariably must be geared to the local situation. A universal formula for ground-water replenishment and withdrawal has no place in the thinking either of the professional or the man in the street. The quantity of water which may be safely withdrawn in one area may not be safely withdrawn from another, and the physical measures designed to promote storage in one area would probably turn out to be unsuitable and ineffective in another.

The present volume has attempted to show, through examples, the experience of selected localities in this country where ground-water problems have occurred. It has set forth the factors affecting supply, development, use, management, and protection. It has attempted further to indicate how each of these factors may be modified or adjusted, within limits, to produce the maximum values from this resource. One of the constant characteristics of each of these locality discussions has been the significance of local factors. However, before attempting to illustrate by selected examples what is meant by 
wise conservation practices in this field of public necessity, some general observations may be made on the ground-water situation for the country as a whole.

At the present time about one-fifth of the total water used in the United States comes from underground sources. This ground-water use is concentrated over particular reservoirs; in many areas, due chiefly to excessive pumping, the local supply is being exhausted at a greater rate than it is naturally recharged. The detailed reasons for this exhaustion are many; they are described in the body of this survey. If some kind of broad generalization must be made, the limited evidence available supports the view that ground water on a nationwide basis is not running out. With ground-water use probably exceeding 25 billion gallons a day, some 15 billions are used in irrigation, 5 billions by industry, 3 billions for municipal systems, and the remainder for rural use exclusive of irrigation. Ground-water use is estimated to have more than doubled from 1935 to 1950 . While the use is increasing and there are areas of obvious deficient water supply for present and future needs, the over-all situation does not disclose any basis for fear that an adequate supply is not available for the Nation's needs.

What is urgently required is to learn quickly and reliably how much water we are using and what our future needs are likely to be. In a nation in which accounting practice has reached a high level of performance in all industrial operations, it is still true unfortunately that for ground- as well as surface-water resources bookkeeping is still inadequate both for current and for long-range purposes. Reporting and accounting are deficient, and yet are required for any intelligent coordinated conservation program.

One forgotten axiom of ground-water development and use is that there is no more water than there is. In other words, one cannot remove from the ground more water than originally fell. This is sometimes attempted or sometimes hoped for in areas where rainfall is unfortunately meager; these high hopes are unrealistic. For example, in the Southern High 
Plains in Texas water is currently being withdrawn at more than 20 times the estimated rate of replenishment. This can be done temporarily only because the irrigated parts of that region are actually drawing on stored water accumulated over many years in the past. The day of reckoning, however, is bound to arrive. The Central Valley Program in southern California is another example of overdevelopment of ground water accumulated over the century. The provision of supplemental water from surface sources in this undertaking is an excellent example of what can be done where the water of a major drainage basin is regarded as a unit and an over-all plan is devised for its effective management.

Managing the surface and ground waters of a drainage basin as a unit is one of three principal lines of action for better conservation of ground water which emerge from Dr. Thomas's survey. What is required within each basin is the planned management of all available water in order that a water budget, balanced on the basis of long-term averages rather than annual replenishment, may be maintained. The second is artificial recharge of developed reservoirs to the extent local conditions and the devices of man permit. The third is management of recharge areas of ground-water reservoirs to provide maximum infiltration of precipitation, or of stream water where the reservoir is along a watercourse.

\section{Some Representative Ground-water Problems}

The analysis below of six ground-water problems should make clear what is involved in selected areas of the country in translating these lines of action in day-by-day execution, and indicate the kind of intcgrated controlled management which should produce the most fruitful results. These examples were chosen to typify the major kinds of ground-water problems encountered as well as to give a reasonably wide geographic spread. In general, these problems result from ignorance of geologic and hydrologic conditions, or from lack of the physical means of securing effective coordination of 
surface- and ground-water storage and use, or because the legal, fiscal, and administrative machinery to accomplish the required coordination is inadequate. Since these problems have been discussed in previous chapters, their details will not be repeated here. A brief summary of each of the experiences, however, is essential to illustrate the diagnostic and regulatory characteristics management programs must take into account.

San Joaquin Valley, Calif. In this valley by far the greatest total use of ground water is made in the United States, a quantity nearly one-quarter of all the water produced by wells throughout the country. About 7,000,000 acre-feet of water is pumped annually from some 40,000 irrigation wells. The ground-water reservoir is recharged either by secpage from stream channels and irrigation canals or by percolation from irrigated lands. The pumping draft exceeds the average ground-water replenishment by about 1,500,000 acre-feet. In many areas the ground-water storage has been progressively declining for many years, yet in other sections the water table has been materially raised and has caused the actual abandonment of some farms. The greatest water deficiencies in precipitation, stream flow, and ground-water replenishment are near the south end of the valley and become progressively less toward the north.

The correction of the situation rests primarily upon importing surplus water from the Sacramento Valley in the north for ground-water replenishment, in order to provide annual and cyclical storage. The conditions of infiltration for storage, movement, and discharge of ground water are so diverse that much more study and exploration are essential before the imported water will be utilized to the maximum. Any comprehensive management program for the best utilization of the ground and surface rvaters will involve a complex management program incorporating at least the following elements: (1) artificial recharge; (2) artificial underground storage over long periods, in extremely large aggregate volumes; (3) due caution not to damage the lands extensively 
by waterlogging; (4) a controlled regimen of pumping from the artificially stored water.

It is unfortunate that the necessary geologic and hydrologic information essential for these fundamental requirements is not yet available. Even if it were available, there is no present assurance that the fundamental requirements listed above are possible of accomplishment in all parts of the area.

Gila River Basin, Ariz. In the ground-water areas of this basin, evapotranspiration losses, major relationships between surface water and ground water, heavy pumping and depletion of underground storage, and increasing salinity in certain areas are the major characteristics. In this basin, too, the amount of water pumped annually is great, approximately $3,000,000$ acre-feet. In many areas the water levels have declined more than 30 feet in the past decade. Here again, hydrologic data are so incomplete that average annual replenishment or the amount of pumped water returned to the ground cannot be firmly estimated.

This is a particularly striking instance of a situation where nonbeneficial vegetation accounts for major water losses. These losses approach 500,000 acre-feet annually, to which, of course, may be added the very large losses in such a climate by evaporation from major surface reservoirs. Salt accumulation has likewise been excessive through the use and reuse of water for irrigation purposes. Dilution with fresh water in this instance can and does afford considerable relief.

Remedies appear to lie in the importation of water, the salvaging of water now wasted, the reduction of salt inflow, and even the reduction of some irrigation lands. All of these measures are competitive or expensive, or both; they are unpopular with some interests and certainly require an over-all management wisdom administratively which usually does not exist.

Houston, Tex. Houston, with a population of nearly 600,000 , is the largest city in the country dependent upon ground water for all municipal and most industrial uses. The pumpage in Houston and adjacent areas has increased from 
50 million gallons a day in 1930 to about 150 million gallons a day at the present time. Water levels simultaneously declined throughout the areas in some instances to more than 100 feet. The amount removed from storage, however, is small in comparison with the vast quantity pumped in the past 20 years. The artesian pressure has declined and a greater inflow into the Houston area has resulted. The encroachment of salt water is improbable at least for many years. The most serious aspect of the lower pressure, therefore, is the increasing cost of pumping water. It is this cost and the realization that the ground-water reservoir is being drawn upon heavily which have led to increasing emphasis on bringing in supplementary water from surface sources.

About 25 miles west of Houston and close to the recharge area, rice growing has developed, with a fivefold increase in pumpage in a period of two decades. In spite of this, in the recharge area the water table has shown no material decline during the last decade. The declines in artesian pressure in this general area, as at Houston, are not due to consistent deficiency in replenishment but to the slow passage of water from the recharge area to the wells.

In the Houston area, therefore, heroic measures appear to be unnecessary, other than a watchful eye over the rate of pumping in future years and the parallel supplementation from surface sources. If the two were simultaneously managed by one agency, the area should not be confronted with significant water problems for some years to come.

Florida, Southeast Coast. The metropolitan Miami area currently uses about 80 million gallons a day, of which 50 million are for municipal use, with the remainder for irrigation and industrial use. Water levels have been lowest principally between the Miami Canal and other uncontrolled tidal canals. Salt water has moved from Biscayne Bay into the principal aquifer. Saline waters entered, for example, Miami's Hialeah well field in 1939. Locks and other control structures are planned on the major canals discharging into Biscayne Bay in order to hold the water on the upstream side during dry 
periods as well as to provide capacity for passing the flood flows during wet seasons.

The precipitation is abundant, and only a small part of the infiltration is actually used. Salt-water encroachment is limited both in area and in extent. In many sections drainage, rather than ground-water availability, is the major problem.

The elements of the control problem in this area are quite simple. They consist primarily in the avoidance of excessive pumping in the vicinity of areas close to shallow, brackish water. More important, but still simple, is the control required to prevent bringing salt-water canals on an uncontrolled basis into close contact with the underground strata.

Peoria, Ill. The gravel deposits in the vicinity of the Illinois River watercourse between Peoria and Pekin are almost 100 feet in thickness. They provide about 85 million gallons a day from wells. The water levels are receding, and the pumpage for some years apparently has exceeded replenishment by seven or eight million gallons a day. Conservation measures primarily directed toward reducing pumpage have resulted in recessions of the water levels in recent years of less than a foot a year. In Peoria itself the saturated part of the aquifer is relatively thin. The inflow of water is insufficient to maintain the present uses.

The studies in the region indicate that recharge from the Illinois River is less satisfactory than in many other areas over the country. Impoundment on the Illinois River has played a part in the replenishment, but siltation appears to be impeding recharge near Peoria. Artificial recharge through large filter beds is now being practiced experimentally and gives some promise of valuable results.

The control program should be somewhat more elaborate than in some of the other examples listed. Control of siltation and of pumping, coupled with improved techniques for increased recharge, should all be part of the management program. This is one of the striking examples of the desirability of extending the water-management program to land-manage- 
ment practices in areas upon which the ground-water recharge is dependent.

Baltimore, Mo. The Baltimore Harbor District has a long history of well-water use, with the first artesian wells drilled in 1853. By 1860 nearly 100 flowing wells were available in this area. Decreases in yield and salt-water contamination began to be apparent in the last part of the nineteenth century. In spite of this, ground-water use increased progressively until 1940, and the area of the take shifted to the Patapsco estuary. Practically all the wells of the Harbor District were abandoned because of contamination by salt or acid waters. Pumpage reached a total of about 47 million gallons a day in 1911 . It was possible to reduce it to 34 million gallons a day in 1942 primarily by substituting, at the Sparrows Point Plant of the Bethlehem Steel Company, treated Baltimore City sewage effluent for some ground-water uses, as well as to supply increasing requirements. Since 1943, other well-water use in the area has varied but slightly, even though virtually all of the ground water pumped has been for industrial purposes. Additional quantities required have been supplied by the public surface-water system.

Most of the water pumped is only slightly contaminated, but few wells are entirely free of contamination. For the deeper artesian aquifers the recharge area lies under the Baltimore Harbor. Saline water has, therefore, penetrated many wells. Pumping the saline waters has retarded the penetration inland of this contamination.

Industrial wastes likewise have been a contaminating influence, not only with respect to the water itself, but with deleterious effects upon casings and abandoned wells. Many of the abandoned wells are probably responsible for contamination of the deeper aquifers, even though a few of the leaking wells have been repaired by cementing.

In recent years a much more detailed management program has gotten under way under the auspices of the State of Maryland. The program embodies control of the installation 
of new wells as well as limitations on pumpage from existing systems. Not too much may be accomplished by recharging, since so large a part of the recharge areas is heavily built up in residential, commercial, and industrial establishments. Little land area or space is now left for any major artificial recharge program, though the possibility is still being investigated.

\section{Major Elements in Ground-water Management}

The examples above are, in general, representative of the various difficulties with ground water in this country, and have been classified in previous chapters as reservoir, pipeline, and watercourse problems, or as miscellaneous difficulties of varying significance. They illustrate and dramatize the major elements encountered in ground-water situations over the country. The remedies suggested should shed light on the kind of general management of this resource which would bring the highest rate of return over the long run.

In most instances the major conservation values would be obtained from a management program which would control withdrawals. The price we have paid for the growth of the country, as far as ground water is concerned, is the decline of well-water levels, increased contamination, and more costly pumpage. Perhaps this was a necessary price to pay for rapid growth. If measures for rigid control had been in successful operation from the beginning, development might have been seriously retarded. In the balance shcet of benefits to the total population, restrictions on withdrawals 50 years ago conceivably might not have been the part of wisdom. At any rate, many areas with difficulties may alleviate them materially by reducing withdrawals at specific wells or in specific areas, or by obtaining water from less developed reservoirs.

A second significant management effort lies in providing for better natural and artificial recharge of important reservoirs. This can only be accomplished by a comprehensive under- 
standing of the geology and the present use of the area under consideration. This is not a hit-or-miss enterprise, but one which would require the highest level of professional competence, and long periods of geologic and hydrologic exploration. Such information is available for few areas in the country at present. Controlled recharge also requires a land-use and management program which varies from insignificance in such regions as the Baltimore area to tremendous importance in the San Joaquin Valley and in the Gila River Basin.

A third effort naturally lies in importing or supplementing by other means water for recharging underground reservoirs. Such a program requires, again, a maximum of professional understanding, coupled with fiscal, legal, and administrative supports. In few instances are all of these elements either potentially or actually operative. Without them, however, no reasonable integrated management is either possible or susceptible of successful operation.

To meet the problems, for example, of the major watercourses, such as the Illinois River in the Peoria area, demands high ingenuity, skillful land management, as well as controlled withdrawals. And it cannot be overemphasized that in no two instances of such watercourse problems are the same solutions or practices indicated.

In all of these endeavors the controlling principles are clear and simple. The practices translating such principles into action are complex and difficult. Complaints regarding declining water levels, recklessness in withdrawal, siltation of recharge areas, contamination of water, and abuses in land practice serve no useful purpose unless they are paralleled by the introduction of both administrative machinery and budgetary sinews to provide continuity of professional diagnosis, by the development of adequate hydrologic, and geologic, geographic data, by the creation of devices by which to manage total enterprises, and by providing the taxation procedures to support management programs. In most instances none of these necessities can be provided in too limited areas or under private 
auspices. The areas and functions to be covered are too extensive and affect too broad a sector of public interest to permit accomplishment except through official public agencies.

It is doubtful whether any part of the management program herein described can be successfully consummated unless the individual states provide the necessary mechanisms and the budgets to carry out the task forever. This is not an undertaking which can be accomplished once and then be forgotten. It is a striking example of the kind of effort which demands permanent and continuing scrutiny, measurement, recording, and control. The venture, incidentally, would be eminently unsuccessful if it did not include both in its motivation and in its decisions the balancing of equities between the necessities of man and the virtues as well as the vices of nature.

A conservation program created by any state would be doomed to failure if it rested upon the principle that not using its water resources is a virtue. Fortunately, controlled use is not inconsistent with preservation of the major water resources of the country. 
Appendix 1

\section{PUMPAGE FROM MAJOR GROUND-WATER RESERVOIRS IN ORDER OF MAGNITUDE}

\begin{tabular}{|c|c|c|}
\hline State & Ground-water reservoir & $\begin{array}{l}\text { Estimated } 1949 \\
\text { draft, acre-feet } a\end{array}$ \\
\hline 1. Calif. & an Joaquin & \\
\hline 2. Ariz. & Salt River Valley & \\
\hline 3. Ariz. & Santa Cruz Valley .. & $0,000 \mathrm{~b}$ \\
\hline 4. Tex.-N.Mex. & Southern High Plains & 0,0008 \\
\hline 5. Calif. & Sacramento Valley .... & $1,000,000$ \\
\hline 6. Tex. & $\begin{array}{r}\text { Balcones Fault Zone (Austin-San An- } \\
\text { tonio-Uvalde) } \ldots \ldots \ldots \ldots \ldots \ldots \ldots \ldots\end{array}$ & \\
\hline 7. Ark. & Mississippi Alluvial Plain ........... & 900,000 b \\
\hline 8. La. & $\begin{array}{r}\text { Southivest rice area (including Lake } \\
\text { Charles) } \ldots \ldots \ldots \ldots \ldots \ldots \ldots \ldots\end{array}$ & 70 \\
\hline 9. Idaho & Snake River Plain ............... & o \\
\hline 10. Calif. & geles Coastal Plain ......... & $0 b$ \\
\hline 11. Colo.-Neb. & e River Valley ......... & $0 d$ \\
\hline 12. Calif. & Sal & $0 b$ \\
\hline 13. Neb. & River Valley & \\
\hline 14. N.Mex. & 11 Basin $\ldots \ldots \ldots \ldots \ldots \ldots$ & $0 b$ \\
\hline 15. Tex. & n-Galveston . & $10 b$ \\
\hline 16. N.Y. & Long & \\
\hline 17. Calif. & . & \\
\hline 18. Calif. & lara Valley $\ldots \ldots \ldots \ldots$ & $0 b$ \\
\hline 19. Calif. & Santa Ana Valley .......... & $0 b$ \\
\hline 20. Calif. & Ventura-Oxnard-Santa Clara Valley & $200,000 b$ \\
\hline 21. Fla. & Central Highlands & 200 \\
\hline 22. Colo. & San Luis Valley ............. & 180,000 \\
\hline 23. Tex. & El Campo rice area...$\ldots \ldots \ldots$ & 160,000 \\
\hline 24. Colo.-Kans & Arkansas River Vallcy & $150,000 d$ \\
\hline 25. Tex. & Pecos River Valley .... & $150,000 \mathrm{~b}, \mathrm{c}$ \\
\hline 26. Tenn. & Memphis $\ldots \ldots \ldots \ldots \ldots$. & $135,000 \mathrm{~b}$ \\
\hline 27. Fla. & Southeast Coast (Miami-Palm Beach) .. & 130,000 \\
\hline
\end{tabular}




\begin{tabular}{|c|c|c|}
\hline State & Ground-water reservoir & $\begin{array}{r}\text { Estimated } 1949 \\
\text { draft, acre-feet }\end{array}$ \\
\hline 28. Calif. & Coachella Valley & 125,000 \\
\hline 29. N.J.-Pa. & Camden-Philadelphia $\ldots \ldots \ldots \ldots \ldots$ & 125,000 \\
\hline 30. Calif. & San Gabriel Valley ................ & 120,000 \\
\hline 31. Ariz. & 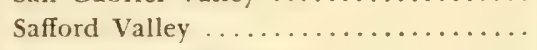 & $110,000 d$ \\
\hline 32. Ohio & Cincinnati-Middletown $\ldots \ldots \ldots \ldots$ & 105,000 \\
\hline 33. Ohio & Dayton $\ldots \ldots \ldots \ldots \ldots \ldots \ldots \ldots \ldots \ldots \ldots$ & 105,000 \\
\hline 34. Calif. & San Fernando Valley ................ & 100,000 \\
\hline 35. Calif. & 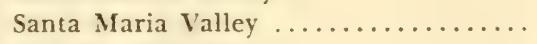 & $100,000 b$ \\
\hline 36. Ill. & East St. Louis-Alton ........... & 100,000 \\
\hline 37. $\mathrm{Pa}$. & Pittsburgh $\quad \ldots \ldots \ldots \ldots \ldots \ldots \ldots \ldots$ & 100,000 \\
\hline 38. Wash. & Puget Sound $\ldots \ldots \ldots \ldots \ldots \ldots \ldots$ & 100,000 \\
\hline 39. III. & Chicago-Joliet $\ldots \ldots \ldots \ldots \ldots \ldots$ & $95,000 \mathrm{~b}$ \\
\hline 40. III. & Peoria-Pekin $\ldots \ldots \ldots \ldots \ldots$ & 95,000 \\
\hline 41. La. & 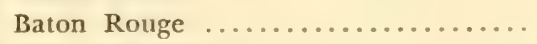 & 75,000 b \\
\hline 42. Ohio & Canton-Massillon $\ldots \ldots \ldots \ldots \ldots \ldots$ & 75,000 \\
\hline 43. Wash. & Spokane Valley .......... & 75,000 \\
\hline 44. Ariz. & Gila Bend . . . . . . . . . . . & 70,000 \\
\hline 45. Calif. & Hollister-Watsonville .............. & $70,000 \mathrm{~b}$ \\
\hline 46. Kans.-Mo. & 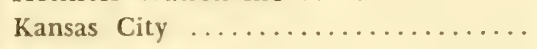 & 70,000 \\
\hline 47. Tex. & Winter Garden . & $70,000 \mathrm{~b}$ \\
\hline 48. Utah & Escalante Valley ............ & $70,000 \mathrm{~b}$ \\
\hline 49. Tex.-Okla. & Northern High Plains ............ & $65,000 \mathrm{~b}$ \\
\hline 50. La. & New Orleans $\ldots \ldots \ldots \ldots \ldots \ldots \ldots$ & 60,000 \\
\hline 51. Mich. & Kalamazoo .................. & 60,000 \\
\hline 52. Minn. & Twin Cities ......... & 60,000 \\
\hline 53. N.Mex. & Mimbres Valley .......... & $60,000 b$ \\
\hline 54. Oreg. & Willamette Valley ........ & 60,000 \\
\hline 55. Wash. & Vancouver $\ldots \ldots \ldots \ldots$ & 60,000 \\
\hline 56. Ariz. & South Gila Basin ................. & 55,000 \\
\hline 57. Ind. & Indianapolis $\ldots \ldots \ldots \ldots \ldots \ldots \ldots$ & 55,000 \\
\hline 58. Ga. & Savannah $\ldots \ldots \ldots \ldots \ldots \ldots \ldots$ & 55,000 \\
\hline 59. Fla. & St. Petersburg-Tampa ..... & 55,000 \\
\hline 60. Ariz. & Wellton-Mohawk ........ & 50,000 \\
\hline 61. Fla. & Jacksonville $\ldots \ldots \ldots \ldots \ldots$ & 50,000 \\
\hline 62. Fla. & Southwest Coast .......... & 50,000 \\
\hline 63. Iowa & Des Moines .............. & 50,000 \\
\hline 64. N.J. & Atlantic Coast ..... & 50,000 \\
\hline 65. Utah & Utah Valley .......... & 50,000 \\
\hline 66. Oreg.-Wash. & Walla Walla Basin ... & $50,000 c$ \\
\hline 67. Ga. & Brunswick ......... & 45,000 \\
\hline 68. N.J. & Middlesex County ......... & 45,000 \\
\hline 69. Fla. & Fernandina $\ldots \ldots \ldots \ldots$ & 40,000 \\
\hline 70. Fla. & Pensacola . & 40,000 \\
\hline 71. Idaho & Boise Valley & 40,000 \\
\hline
\end{tabular}




\begin{tabular}{|c|c|c|}
\hline State & Ground-water reservoir & $\begin{array}{c}\text { Estimated } 1949 \\
\text { draft, acre-feet } a\end{array}$ \\
\hline 72. Ky. & Louisville & 40,000 \\
\hline 73. Md. & Baltimore .... & 40,000 \\
\hline 74. Tex. & 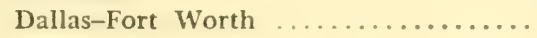 & 40,000 b \\
\hline 75. Utah & Jordan Valley (Salt Lake City) ......... & 40,000 \\
\hline 76. Ala. & Mobile ................... & 35,000 \\
\hline 77. Ind. & South Bend & 35,000 \\
\hline 78. Nev. & 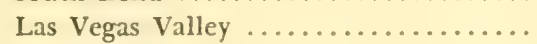 & $35,000 \mathrm{~b}$ \\
\hline 79. Nev. & 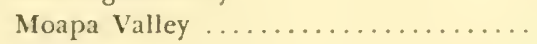 & $35,000 \mathrm{c}$ \\
\hline 80. N.Y. & Binghamton .... & 35,000 \\
\hline 81. Ohio & Akron $\ldots \ldots \ldots$ & 35,000 \\
\hline 82. Tex. & Salt Flat Basin $\ldots \ldots \ldots \ldots \ldots \ldots \ldots$ & $35,000 b$ \\
\hline 83. Ala. & Montgomery $\ldots \ldots \ldots \ldots \ldots \ldots \ldots$ & 30,000 \\
\hline 84. Ariz. & Douglas Basin & 30,000 \\
\hline 85. Ariz. & Willcox Basin & 30,000 \\
\hline 86. Calif. & 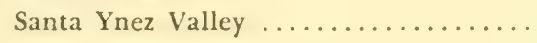 & 30,000 \\
\hline 87. Ill. & Rockford ....... & 30,000 \\
\hline 88. Iowa & Sioux City . . . . . . . & 30,000 \\
\hline 89. Neb.-Wyo. & North Platte Valley ................. & 30,000 \\
\hline 90. N.J. & Rahway Valley $\ldots \ldots \ldots \ldots \ldots \ldots$ & 30,000 \\
\hline 91. N.Y. & Schenectady $\quad . . . . . . .$. & 30,000 \\
\hline 92. Ohio & Chillicothe $\ldots \ldots \ldots \ldots$ & 30,000 \\
\hline 93. Ohio & Columbus $\ldots \ldots \ldots \ldots \ldots \ldots \ldots$ & 30,000 \\
\hline 94. Ore. & 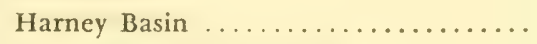 & $30,000 \bullet$ \\
\hline 95. Tex. & Lower Rio Grande Valley. & 30,000 \\
\hline 96. Utah & East Shore Area ........ & 30,000 \\
\hline 97. Ariz.-N.Mex. & Duncan-Virden Valley & $25,000 d$ \\
\hline 98. Calif. & Tehachapi Valley ..... & 25,000 \\
\hline 99. Kans. & Wichita $\ldots \ldots \ldots \ldots$ & 25,000 \\
\hline 100. La. & Norco ................ & 25,000 \\
\hline 101. Md. & Eastern Shore .............. & 25,000 \\
\hline 102. Mass. & Boston $\ldots \ldots \ldots \ldots$ & 25,000 \\
\hline 103. Mich. & Lansing $\ldots . . .$. & 25,000 \\
\hline 104. Mich. & Pontiac $\ldots \ldots \ldots \ldots \ldots$ & 25,000 \\
\hline 105. Tex. & El Paso $\ldots \ldots \ldots \ldots$ & 25,000 \\
\hline 106. Va. & Waynesboro ........ & 25,000 \\
\hline 107. Wis. & Milwaukee-Waukesha ... & 25,000 \\
\hline
\end{tabular}

a An acre-foot is 325,851 gallons. Annual draft of 10,000 acre-fect is approximately equivalent to 9 million gallons per day and requires a continuous discharge of about 14 cubic feet per second.

$b$ Draft is partly from storage.

- Discharged chiefly by springs.

d Maximum; large variation from year to year, depending upon availability of surface water. 
Appendix 2

\section{INDEX OF LOGALITIES}

\begin{tabular}{|c|c|c|c|c|}
\hline State & $\begin{array}{l}\text { Ground-water } \\
\text { reservoir }\end{array}$ & $\begin{array}{l}\text { Part of } \\
\text { reservoir }\end{array}$ & $\begin{array}{c}\text { Type of } \\
\text { problem } a\end{array}$ & $\begin{array}{c}\text { Page } \\
\text { references } 8\end{array}$ \\
\hline \multirow[t]{4}{*}{ Ala. } & $\ldots \ldots \ldots \ldots \ldots \ldots$ & Dothan & 2 & \\
\hline & & Mobile & 3 & 147 \\
\hline & & Montgomery & 2,3 & 120 \\
\hline & & Selma & 2,3 & \\
\hline \multirow[t]{4}{*}{ Ark. } & ....... & Crossett & 2 & \\
\hline & & El Dorado & 2 & 111 \\
\hline & & Grand Prairie & 1 & 49 \\
\hline & & Pine Bluff & 4 & 203 \\
\hline \multirow[t]{16}{*}{ Ariz. } & Ajo Valley & . & 1 & 42 \\
\hline & Bouse Valley & $\ldots$ & 1 & 42 \\
\hline & Centennial Wash & $\ldots \ldots \ldots \ldots \ldots \ldots$ & 1 & 42 \\
\hline & Duncan Valley & n.............. & 3 & 151 \\
\hline & Gila Bend & n............. & 1,3 & 60 \\
\hline & & Miami & 4 & 203 \\
\hline & Safford Valley & $\ldots \ldots \ldots \ldots \ldots$ & 3 & 84,151 \\
\hline & Salt River Valley & $\ldots \ldots \ldots \ldots \ldots \ldots$ & 1,3 & 75,284 \\
\hline & Salt River Valley & Deer Valley & 2 & 75 \\
\hline & Salt River Valley & Queen Creek & 2 & 226 \\
\hline & Salt River Valley & Sierra Ancha Forest & 4 & 184 \\
\hline & San Pedro Valley & n.............. & 1 & \\
\hline & Santa Cruz Valley & $\ldots \ldots \ldots \ldots \ldots \ldots$ & 1 & 37 \\
\hline & Santa Cruz Valley & Eloy & 2 & 38 \\
\hline & Wellton-Mohawk & $\ldots \ldots \ldots \ldots \ldots \ldots$ & 1,3 & 59 \\
\hline & Willcox Basin & n.w. & 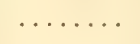 & 82 \\
\hline \multirow[t]{7}{*}{ Calif. } & Antelope Valley & .. & 1 & 39 \\
\hline & Carpinteria Valley & $\ldots \ldots \ldots \ldots \ldots$ & 1 & 69 \\
\hline & Clear Lake Valley & $\ldots \ldots \ldots \ldots \ldots \ldots$ & 1 & \\
\hline & Coachella Valley & $\ldots \ldots \ldots \ldots \ldots \ldots$ & 1 & 22,69 \\
\hline & Cuyama Valley & $\ldots \ldots \ldots \ldots \ldots \ldots$ & 1 & 55 \\
\hline & Fairfield Valley & $\ldots \ldots \ldots \ldots \ldots \ldots$ & 1 & \\
\hline & Goleta Valley & $\ldots \ldots \ldots \ldots \ldots \ldots$ & 1 & 69 \\
\hline
\end{tabular}




\begin{tabular}{|c|c|c|c|c|}
\hline State & $\begin{array}{l}\text { Ground-water } \\
\text { reservoir }\end{array}$ & $\begin{array}{l}\text { Part of } \\
\text { reservoir }\end{array}$ & $\begin{array}{c}\text { Type of } \\
\text { problem } a\end{array}$ & $\begin{array}{c}\text { Page } \\
\text { references o }\end{array}$ \\
\hline & $\begin{array}{l}\text { Hollister-Watsonville } \\
\text { Imperial Valley } \\
\text { Livermore Valley } \\
\text { Los Angeles Coastal } \\
\text { Plain } \\
\text { Los Angeles Coastal } \\
\text { Plain } \\
\text { Los Angeles Coastal } \\
\text { Plain } \\
\text { Sacramento Valley } \\
\text { Salinas Valley } \\
\text { San Diego Valley } \\
\text { San Fernando Valley } \\
\text { San Gabriel Valley } \\
\text { San Jacinto Valley } \\
\text { San Joaquin Valley } \\
\text { San Joaquin Valley } \\
\text { San Joaquin Valley } \\
\text { San Joaquin Valley } \\
\text { San Joaquin Valley } \\
\text { San Joaquin Valley } \\
\text { Santa Ana Valley } \\
\text { Santa Barbara Valley } \\
\text { Santa Clara Valley } \\
\text { Santa Margarita Valley } \\
\text { Santa Maria Valley } \\
\text { Tia Juana Valley } \\
\text { Ventura-Oxnard } \\
\text { Plain } \\
\text { Ventura-Oxnard } \\
\text { Plain }\end{array}$ & 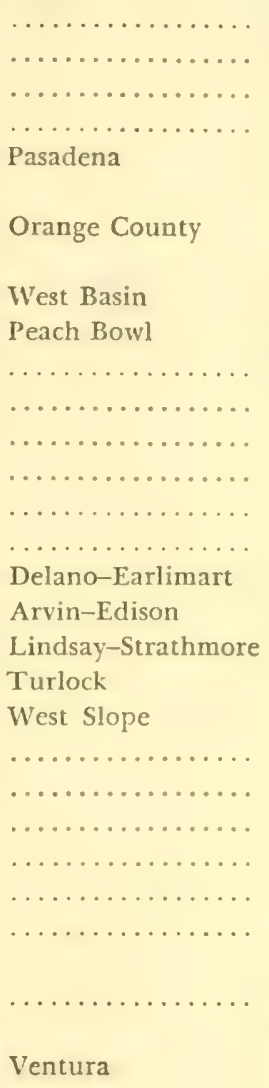 & $\begin{array}{l}4 \\
2 \\
2 \\
1,2 \\
1 \\
4 \\
\ldots \ldots \\
1 \\
1 \\
2 \\
2 \\
2 \\
4 \\
1 \\
1 \\
1 \\
1 \\
1 \\
1 \\
1\end{array}$ & $\begin{array}{l}39 \\
70,283 \\
71 \\
71 \\
73 \\
197 \\
43 \\
189 \\
69 \\
52 \\
\\
55,67 \\
61 \\
\\
55\end{array}$ \\
\hline Colo. & $\begin{array}{l}\text { Arkansas River Valley } \\
\text { South Platte Valley } \\
\text { South Platte Valley } \\
\text { South Platte Valley }\end{array}$ & $\begin{array}{l}\text { Beaver Creek } \\
\text { Bijou Creek } \\
\text { Prospect Creek } \\
\text { Denver } \\
\text { Grand Junction } \\
\text { Rocky Ford }\end{array}$ & $\begin{array}{l}3 \\
2 \\
2 \\
2 \\
2 \\
2 \\
2\end{array}$ & 156 \\
\hline Conn. & $\begin{array}{l}\text { San Luis Valley } \\
\ldots \ldots \ldots \ldots \ldots \ldots \ldots\end{array}$ & $\begin{array}{l}\text { Bridgeport } \\
\text { New Haven }\end{array}$ & $\begin{array}{l}4 \\
3 \\
3\end{array}$ & $\begin{array}{l}87,197 \\
147 \\
147\end{array}$ \\
\hline Del. & n & Lewes & 4 & 208 \\
\hline
\end{tabular}




\begin{tabular}{|c|c|c|c|c|}
\hline State & $\begin{array}{l}\text { Ground-water } \\
\text { reservoir }\end{array}$ & $\begin{array}{l}\text { Part of } \\
\text { reservoir }\end{array}$ & $\begin{array}{c}\text { Type of } \\
\text { problem } a\end{array}$ & $\begin{array}{c}\text { Page } \\
\text { references } b\end{array}$ \\
\hline Fla. & $\ldots \ldots \ldots \ldots \ldots \ldots \ldots$ & $\begin{array}{l}\text { Atlantic-Gulf Canal } \\
\text { Everglades } \\
\text { Fernandina } \\
\text { Ft. Lauderdale } \\
\text { Ft. Myers } \\
\text { Ft. Pierce } \\
\text { Jacksonville } \\
\text { Miami } \\
\text { Orlando } \\
\text { Panama City } \\
\text { Pensacola } \\
\text { Port Joe } \\
\text { St. Petersburg } \\
\text { Sanford } \\
\text { Sarasota } \\
\text { Stuart } \\
\text { Tampa } \\
\text { West Palm Beach }\end{array}$ & $\begin{array}{l}4 \\
4 \\
2 \\
2 \\
2,4 \\
2 \\
2 \\
2,4 \\
4 \\
2 \\
2 \\
2 \\
2 \\
4 \\
2 \\
2 \\
4 \\
2,4\end{array}$ & $\begin{array}{l}211 \\
194 \\
132 \\
195 \\
147,203 \\
134 \\
116 \\
194,285 \\
202 \\
132 \\
133 \\
212 \\
134 \\
133 \\
195\end{array}$ \\
\hline Ga. & 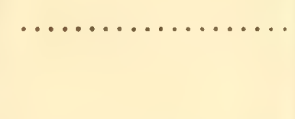 & $\begin{array}{l}\text { Brunswick } \\
\text { St. Mary's } \\
\text { Savannah }\end{array}$ & $\begin{array}{l}2 \\
2 \\
2\end{array}$ & $\begin{array}{l}132 \\
132\end{array}$ \\
\hline Idaho & $\begin{array}{l}\text { Cache Valley } \\
\text { Snake River Plain }\end{array}$ & $\begin{array}{l}\text { Malad } \\
\text { Moscow } \\
\ldots \ldots \ldots \ldots \ldots \ldots \\
\ldots \ldots \ldots \ldots \ldots \ldots\end{array}$ & $\begin{array}{l}2 \\
2 \\
4 \\
4\end{array}$ & $\begin{array}{r}198 \\
89\end{array}$ \\
\hline Ill. & & $\begin{array}{l}\text { Champaign } \\
\text { Chicago } \\
\text { East St. Louis } \\
\text { Joliet } \\
\text { Peoria } \\
\text { Rockford }\end{array}$ & $\begin{array}{l}2 \\
2 \\
3 \\
2 \\
3 \\
2\end{array}$ & $\begin{array}{l}104 \\
145 \\
104 \\
143,286 \\
116\end{array}$ \\
\hline Ind. & n............... & $\begin{array}{l}\text { Elkhart } \\
\text { Indianapolis } \\
\text { Lawrenceburg } \\
\text { South Bend }\end{array}$ & $\begin{array}{l}2 \\
2,3 \\
3 \\
2,3\end{array}$ & $\begin{array}{l}145 \\
207 \\
145\end{array}$ \\
\hline Iowa & $\ldots \ldots \ldots \ldots \ldots \ldots, \ldots$ & $\begin{array}{l}\text { Cedar Rapids } \\
\text { Clinton } \\
\text { Des Moines } \\
\text { Dubuque } \\
\text { Mason City } \\
\text { Ottumwa } \\
\text { Sioux City }\end{array}$ & $\begin{array}{l}2 \\
2 \\
3 \\
2 \\
2 \\
2 \\
2\end{array}$ & 142 \\
\hline
\end{tabular}


APPENDIX 2

\begin{tabular}{|c|c|c|c|c|}
\hline State & $\begin{array}{l}\text { Ground-water } \\
\text { reservoir }\end{array}$ & $\begin{array}{l}\text { Part of } \\
\text { reservoir }\end{array}$ & $\begin{array}{c}\text { Type of } \\
\text { problem } a\end{array}$ & $\begin{array}{c}\text { Page } \\
\text { references } b\end{array}$ \\
\hline Kans. & $\begin{array}{l}\text { Arkansas River Valley } \\
\text { High Plains } \\
\text { High Plains }\end{array}$ & $\begin{array}{l}\ldots \ldots \ldots \ldots \ldots \\
\text { Scott County } \\
\text { Wichita }\end{array}$ & $\begin{array}{l}3 \\
\cdots \ldots \\
2 \\
3\end{array}$ & $\begin{array}{r}156 \\
47 \\
47\end{array}$ \\
\hline Ky. & $\ldots \ldots \ldots \ldots \ldots \ldots \ldots$ & $\begin{array}{l}\text { Beaver Dam } \\
\text { Louisville }\end{array}$ & $\begin{array}{l}2 \\
3\end{array}$ & 141 \\
\hline La. & ............ & $\begin{array}{l}\text { Alexandria } \\
\text { Bastrop } \\
\text { Baton Rouge } \\
\text { Hodge } \\
\text { Lake Charles } \\
\text { Monroe } \\
\text { Natchitoches } \\
\text { Norco } \\
\text { Rice area } \\
\text { Shreveport } \\
\text { Ville Platte }\end{array}$ & $\begin{array}{l}2 \\
2 \\
2 \\
2 \\
2 \\
2 \\
2 \\
2 \\
1 \\
2,3 \\
2\end{array}$ & $\begin{array}{l}120 \\
120 \\
106 \\
120 \\
106 \\
121,150\end{array}$ \\
\hline Md. & $\ldots \ldots \ldots \ldots \ldots \ldots \ldots$ & $\begin{array}{l}\text { Baltimore } \\
\text { Cambridge } \\
\text { Ocean City }\end{array}$ & $\begin{array}{l}2 \\
2 \\
2\end{array}$ & 130,287 \\
\hline Mass. & .. & Provincetown & 2 & 124 \\
\hline Mich. & $\ldots \ldots \ldots \ldots \ldots \ldots \ldots$ & $\begin{array}{l}\text { Battle Creek } \\
\text { Escanaba } \\
\text { Jackson } \\
\text { Lansing } \\
\text { Kalamazoo } \\
\text { Pontiac }\end{array}$ & $\begin{array}{l}2,3 \\
2 \\
2 \\
2,3 \\
3 \\
2,3\end{array}$ & $\begin{array}{l}119 \\
204\end{array}$ \\
\hline Minn. & $\ldots \ldots \ldots \ldots \ldots \ldots$ & $\begin{array}{l}\text { Minneapolis } \\
\text { Moorhead } \\
\text { St. Paul }\end{array}$ & $\begin{array}{l}2 \\
2 \\
2\end{array}$ & $\begin{array}{l}117 \\
117\end{array}$ \\
\hline Miss. & $\ldots \ldots \ldots$ & $\begin{array}{l}\text { Biloxi } \\
\text { Gulfport }\end{array}$ & $\begin{array}{l}2 \\
2\end{array}$ & 132 \\
\hline Mo. & $\ldots \ldots$ & $\begin{array}{l}\text { Columbia } \\
\text { Jefferson City } \\
\text { Joplin } \\
\text { Sedalia } \\
\text { Springfield }\end{array}$ & $\begin{array}{l}2 \\
2 \\
2 \\
2 \\
2\end{array}$ & \\
\hline
\end{tabular}




\begin{tabular}{|c|c|c|c|c|}
\hline State & $\begin{array}{l}\text { Ground-water } \\
\text { reservoir }\end{array}$ & $\begin{array}{l}\text { Part of } \\
\text { reservoir }\end{array}$ & $\begin{array}{l}\text { Type of } \\
\text { problem } a\end{array}$ & $\begin{array}{c}\text { Page } \\
\text { references b }\end{array}$ \\
\hline Mont. & & Helena Valley & 4 & 86 \\
\hline Nebr. & $\begin{array}{l}\text { Great Plains } \\
\text { Platte River Valley } \\
\text { Platte River Valley } \\
\text { Platte River Valley }\end{array}$ & $\begin{array}{l}\text { Sand Hills } \\
\ldots \ldots \ldots \ldots \ldots . . . . \\
\text { Grand Island } \\
\text { Hall County } \\
\text { Lincoln } \\
\text { Omaha }\end{array}$ & $\begin{array}{l}4 \\
3 \\
2 \\
2 \\
2 \\
2\end{array}$ & $\begin{array}{l}47,164 \\
154 \\
155\end{array}$ \\
\hline Nev. & Las Vegas Valley & & 1,2 & 65 \\
\hline N.J. & $\ldots \ldots \ldots \ldots$ & $\begin{array}{l}\text { Asbury Park } \\
\text { Atlantic City } \\
\text { Camden } \\
\text { Cape May } \\
\text { Intracoastal } \\
\quad \text { Waterway } \\
\text { Newark } \\
\text { Perth Amboy } \\
\text { Runyon } \\
\text {......................... }\end{array}$ & $\begin{array}{l}2,4 \\
2 \\
3 \\
2,4 \\
4 \\
2 \\
2 \\
4 \\
1\end{array}$ & $\begin{array}{l}127,210 \\
128 \\
149 \\
127,208 \\
\\
209 \\
127 \\
128,210 \\
208 \\
91\end{array}$ \\
\hline N.Mex. & $\begin{array}{l}\text { Animas Valley } \\
\text { Elephant Butte } \\
\text { High Plains } \\
\text { High Plains } \\
\text { High Plains } \\
\text { High Plains } \\
\text { Middle Rio Grande } \\
\text { Valley } \\
\text { Mesilla Vallev } \\
\text { Mimbres Valley } \\
\text { Playas Valley } \\
\text { Rincon Valley } \\
\text { Roswell Basin } \\
\text { Virden Valley }\end{array}$ & 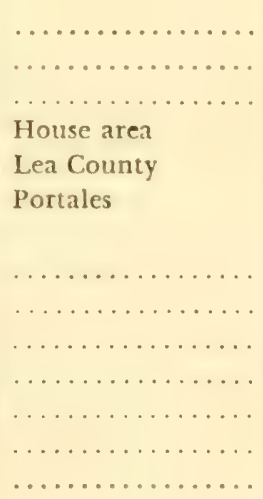 & $\begin{array}{l}1 \\
3,4 \\
1 \\
2 \\
2 \\
2 \\
3,4 \\
4 \\
1 \\
1 \\
4 \\
1 \\
3\end{array}$ & $\begin{array}{r}151 \\
153 \\
40 \\
\\
153 \\
62 \\
151\end{array}$ \\
\hline N.Y. & $\begin{array}{l}\text { Long Island } \\
\text { Long Island }\end{array}$ & $\begin{array}{l}\text { Brooklyn } \\
\text { Queens } \\
\text { Binghamton } \\
\text { Corning } \\
\text { Jamestown } \\
\text { Schenectady }\end{array}$ & $\begin{array}{l}2 \\
2 \\
2 \\
2 \\
2 \\
3\end{array}$ & $\begin{array}{l}124,192 \\
125\end{array}$ \\
\hline
\end{tabular}




\begin{tabular}{|c|c|c|c|c|}
\hline State & $\begin{array}{l}\text { Ground-water } \\
\text { reservoir }\end{array}$ & $\begin{array}{l}\text { Part of } \\
\text { reservoir }\end{array}$ & $\begin{array}{c}\text { Type of } \\
\text { problem } a\end{array}$ & $\begin{array}{c}\text { Page } \\
\text { references } b\end{array}$ \\
\hline N.C. & .................. & $\begin{array}{l}\text { Coweeta Forest } \\
\text { Wilmington }\end{array}$ & $\begin{array}{l}4 \\
3\end{array}$ & $\begin{array}{l}177 \\
147\end{array}$ \\
\hline N.D. & $\begin{array}{l}\text { Drift Prairie } \\
\text { Great Plains }\end{array}$ & $\begin{array}{l}\text { Devils Lake } \\
\text { Dickinson } \\
\text { Fargo } \\
\text { Fessenden } \\
\ldots \ldots \ldots \ldots \text {................ }\end{array}$ & $\begin{array}{l}4 \\
2 \\
2 \\
1 \\
1,2\end{array}$ & $\begin{array}{r}175 \\
115 \\
\\
47 \\
101\end{array}$ \\
\hline Ohio & $\ldots \ldots \ldots \ldots \ldots \ldots \ldots$ & $\begin{array}{l}\text { Canton } \\
\text { Columbus } \\
\text { Dayton } \\
\text { Mill Creek Valley } \\
\text { Toledo }\end{array}$ & $\begin{array}{l}3 \\
2 \\
3 \\
2 \\
2\end{array}$ & $\begin{array}{l}146 \\
145 \\
111\end{array}$ \\
\hline Okla. & $\begin{array}{l}\text { Enid Terrace } \\
\text { High Plains }\end{array}$ & $\begin{array}{l}\ldots \ldots \ldots \ldots \ldots \ldots \\
\ldots \ldots \ldots \ldots \ldots \ldots \\
\text { Miami } \\
\text { Norman } \\
\text { Oklahoma City } \\
\text { Ponca City }\end{array}$ & $\begin{array}{l}1 \\
1 \\
2 \\
2 \\
2,3 \\
3\end{array}$ & $\begin{array}{r}92 \\
47 \\
114 \\
109 \\
118 \\
149\end{array}$ \\
\hline Ore. & Willamette Valley & $\ldots \ldots \ldots \ldots \ldots \ldots$ & $\ldots \ldots$ & 88 \\
\hline $\mathrm{Pa}$. & $\begin{array}{l}\text { Susquehanna River } \\
\text { Basin }\end{array}$ & $\begin{array}{l}\text { Philadelphia } \\
\text { Pittsburgh } \\
\\
\text {................ }\end{array}$ & $\begin{array}{l}3 \\
3 \\
4\end{array}$ & $\begin{array}{l}149,204 \\
139 \\
297\end{array}$ \\
\hline R.I. & ... & Providence & 2 & \\
\hline S.C. & $\ldots \ldots \ldots \ldots \ldots \ldots \ldots$ & $\begin{array}{l}\text { Charleston } \\
\text { Florence } \\
\text { Georgetown }\end{array}$ & $\begin{array}{l}2 \\
2 \\
2\end{array}$ & \\
\hline S.D. & Great Plains & ........... & 2 & 101 \\
\hline Tenn. & ................ & $\begin{array}{l}\text { Copper Basin } \\
\text { Memphis }\end{array}$ & $\begin{array}{l}4 \\
2\end{array}$ & $\begin{array}{l}180 \\
110,224\end{array}$ \\
\hline Tex. & $\ldots \ldots \ldots \ldots \ldots$ & $\begin{array}{l}\text { Atascosa County } \\
\text { Baytown } \\
\text { Dallas } \\
\text { El Campo } \\
\text { El Paso } \\
\text { Fort Worth } \\
\text { Galveston }\end{array}$ & $\begin{array}{l}2 \\
2 \\
2 \\
2 \\
2,3 \\
2 \\
2\end{array}$ & $\begin{array}{l}135 \\
123 \\
115 \\
\\
57,148 \\
115 \\
123\end{array}$ \\
\hline
\end{tabular}




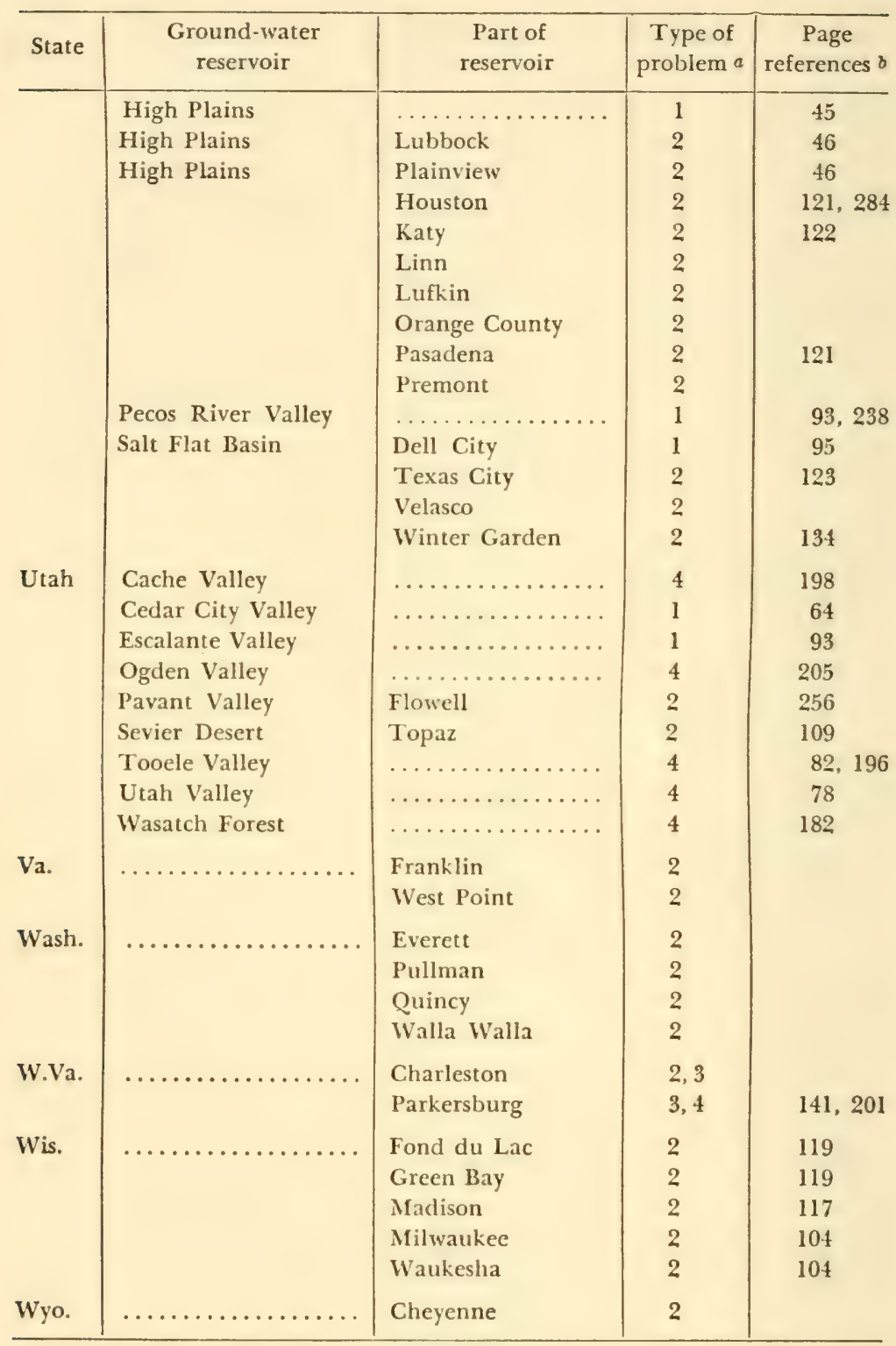

a (1) Reservoir. (2) Pipeline. (3) Watercourse. (4) Miscellaneous.

$b$ References are to pages in this book. See also Plates II and III. 
Appendix 3

\section{SELEGTED BIBLIOGRAPHY OF AREAL GROUND-WATER STUDIES}

Ajo Valley, Ariz.

Barr, A. T., and E. C. Sandberg, "The Part Water Plays in Mining," New Cornelia Branch, Phelps-Dodge Corp., Ajo, Ariz., Mimeo rept., 1941, 16 pp.

Alexandria, La.

Maher, J. C., and P. H. Jones, Ground-water Exploration at Alexandria, Louisiana, Econ. Geol., vol. 40, pp. 164-182, 1945.

Antelope Valley, Calif.

"Antelope Valley-South Coastal Basin Investigations,"

Calif. Div. Water Resources, unpublished data.

Asbury Park, N.J.

Thompson, D. G., Ground-water Supplies in the Vicinity of Asbury Park, N.J. Dept. Cons. and Dev. Bull. 35, 1930, 50 pp.

Atlantic City, N.J.

Barksdale, H. C., R. M. Sundstrom, and M. S. Bronstein, Supplementary Report on the Ground-water Supplies of the Atlantic City Region, N.J. State Water Policy Commission Special Rept. 6, 1936, 132 pp.

Atlantic-Gulf Ship Canal, Fla.

"Waterway from Cumberland Sound, Georgia and Florida, to the Mississippi River; Geology and Ground Water," U.S. Engineering Office, Jacksonville, Fla., December 30, 1933. 
Beckman, H. H., Documentary History of Florida Canal, 74th Congress, Senate Doc. 275, pp. 159-161, 409415, etc., 1936.

Thompson, D. G., O. E. Meinzer, and V. T. Stringfield, Effect of a Sea-level Canal on the Ground-water Level of Florida, Econ. Geol., vol. 33, pp. 87-107, 1938.

Arkansas River Valley, Kans.

Waite, H. A., Geology and Ground-water Resources of Ford County, Kansas, Kans. Geol. Survey Bull. 43, 1942, 250 pp.

McLaughlin, T. G., Geology and Ground-water Resources of Hamilton and Kearney Counties, Kansas, Kans. Geol. Survey Bull. 49, 1943, 220 pp.

Latta, B. F., Geology and Ground-water Resources of Finney and Gray Counties, Kansas, Kans. Geol. Survey Bull. 55, 1944, 272 pp.

Frye, J. C., and V. C. Fishel, "Ground Water in Southwestern Kansas," Kans. Geol. Survey, 1949, 24 pp.

Williams, C. C., and S. W. Lohman, Geology and Ground-water Resources of a Part of South Central Kansas, Kans. Geol. Survey Bull. 79, 1949, 451 pp.

Arkansas River Valley, Okla.

Schoff, S. L. and E. W'. Reed, Ground W'ater in Alluvial Deposits in Oklahoma, Econ. Geol., vol. 46, pp. 76-83, 1951 .

Baltimore, $M d$.

Bennett, R. R., Ground Water in the Baltimore Area, Maryland, Board of Nat. Res. Educ. Ser. 13, 1946, 15 pp.

Bennett, R. R., and R. R. Meyer, "Geology and Groundwater Resources of the Baltimore Area, Maryland," U.S. Geol. Survey rept., in preparation.

Baton Rouge, La.

Cushing, E. M., and P. H. Jones, "Ground-water Conditions of the Baton Rouge Area, Louisiana," La. Dept. Public Works, Mimeo. rept., 1945, 37 pp. 
Biloxi, Miss. (See Gulfport, Miss.)

Bouse Valley, Ariz.

"Ground Water in Bouse Area of Ranegras Plain, Arizona," U.S. Geol. Survey rept., in preparation.

Brooklyn, N.Y.

Brashears, M. L., Artificial Recharge of Ground Water on Long Island, New York, Econ. Geol., vol. 41, pp. 503-515, 1946.

Lusczynski, N.J., "Withdrawal of Ground Water and Pond Water on Long Island from 1904 to 1949," U.S. Geol. Survey, Typed rept., 1950, 3 pp.

Jacob, C. E., The Water Table in the Western and Central Part of Long Island, New York, N.Y. Water Power and Control Commission Bull. GW-12, 1945, 24 pp; Correlation of Ground-water Levels and Precipitation, Bull. GW-14, 1945.

Brunswick, Ga. (See Savannah, Ga.)

Cache Valley, Utah

Peterson, W., Ground-water Supply in Cache Valley, Utah, Utah State Agr. Ext. Service N.S. 133, 1946, 102 pp.

Israelsen, O. W., and W. W. McLaughlin, Drainage of Land Overlying an Artesian Ground-rvater Reservoir, Utah Agr. Exp. Sta. Bull. 242, 1932, 56 pp.; Bull. 259, 1935, $32 \mathrm{pp}$.

Camden, N.J.

Graham, J. B., Ground-water Problems in the Philadelphia Area, Econ. Geol., vol. 45, pp. 210-221, 1950.

Canton, Ohio

Schaefer, E. J., G. W. White, and D. W. Van Tuyl, The Ground-rvater Resources of the Glacial Deposits in the Vicinity of Canton, Ohio, Ohio Water Res. Board Bull. 3, June 1946.

Kazmann, R. G., The Utilization of Induced Stream Infiltration and Natural Aquifer Storage at Canton, Ohio, Econ. Geol., vol. 44, pp. 514-524, 1949. 
Cape May, N.J.

Barksdale, N.C., Depletion of Ground Water in New Jersey, Jour. Am. Water Works Assoc., vol. 41, pp. $511-515,1949$.

Carpinteria Valley, Calif. (See Santa Barbara Valley, Calif.)

Cedar City Valley, Utah

Thomas, H. E., and G. H. Taylor, Geology and Groundwater Resources of Cedar City and Parowan Valleys, Utah, U.S. Geol. Survey Water Supply Paper 993, 1946, 210 pp.

Chicago, Ill.

Control of Ground Water, Ill. Legislative Council Publ. 88, pp. 5-11, 1948.

Chicago Area Water Supply, a Symposium, Midwest Engr., vol. 2, pp. 6-21, February 1950.

Coachella Valley, Calif.

Huberty, M. R., et al., "Hydrologic Studies in Coachella Valley, California," Univ. Calif. Agr. Exp. Sta. rept., 1948, 31 pp.

Copper Basin, Tenn.

Hursh, C. R., Local Climate in the Copper Basin of Tennessee as Modified by the Removal of Vegetation, U.S. Dept. Agr. Tech. Bull. 774, 1948, 38 pp.

Hixson, Fred, Conservation Plan in Copper Basin Starts Tree Growth on Barren Land, Chattanooga Times, April 17, 1950.

Coweeta Experimental Forest, N.C.

"Coweeta Experimental Forest Watershed Management Research," U.S. Forest Service, 1948, 40 pp.

Hursh, C. E., and E. F. Brater, Separating Storm Hydrographs from Small Drainage into Surface and Subsurface Flow, Trans. Am. Geophys. Union, vol. 22, pp. 863-870, 1941.

Dunford, E. G., and P. W. Fletcher, Effect of Removal 
of Streambank Vegetation upon Water Yields, Trans. Am. Geophys. Union, vol. 28, pp. 105-110, 1947.

Crossett, Ark.

Hewitt, F. A., R. C. Baker, and G. A. Billingsley, Ground-water Resources of Ashley County, Arkansas, Univ. Ark. Inst. Science and Technol., Research Ser. 16, 1949, 33 pp.

Dallas, Tex.

"Water Facts in Relation to a National Water-resources Policy," U.S. Geol. Survey, Mimeo. rept., Appendix C, p. 112, April 1950.

Dayton, Ohio

Norris, S. E., The Water Resources of Montgomery County, Ohio, Ohio Water Res. Board Bull. 12, 1948, 83 pp.

Dell City, Tex. (See Salt Flat Basin, Tex.)

Des Moines, Iowa

Burdick, C. B., Basic Principles of Ground Water Collection, Proc. Am. Water Works Assoc., 1913, p. 257.

Maffitt, D. L., Artificial Flooding Builds up Groundwater Yield, Water Works Eng., vol. 96, no. 22, pp. 1230-1232, 1943.

Board of Water Works Trustees, Description of Des Moines Water Works System (1945), and Annual Report for 1949.

Devils Lake, N.D.

Simpson, H. E., Physiography of the Devils Lake-Stump Lake Region of North Dakota, N.D. Geol. Survey 6th Bienn. Rept., Pp. 105-157, 1912; Geology and Ground-water Resources of North Dakota, U.S. Geol. Survey Water Supply Paper 598, pp. 190-191, 1929.

Swenson, H. A., "Chemical Character of Surface Waters in the Devils Lake Basin, North Dakota," U.S. Geol. Survey, Mimeo. rept., 1950, 46 pp. 
Dickinson, N.D.

McLaughlin, T. G., "Ground Water at Dickinson, North Dakota," U.S. Geol. Survey, Mimeo. rept., 1946, $31 \mathrm{pp}$.

Tycksen, P. C., Geology and Ground-water Hydrology of the Heart River Irrigation Project and the Dickinson Area, North Dakota, U.S. Geol. Survey Circ. 34, 1950, 59 pp.

Duncan Valley, Ariz.

Turner, S. F., et al., "Water Resources of Safford and Duncan-Virden Valleys, Arizona and New Mexico," U.S. Geol. Survey, Mimeo. rept., 1941.

East St. Louis, Ill.

Control of Ground Water, Ill. Legislative Council Publ. 88, pp. 5-11, 1948.

El Dorado, Ark.

Baker, R. C., F. A. Hewitt, and G. A. Billingsley, Ground-water Resources of the El Dorado Area, Arkansas, Univ. Ark. Bur. Research, Research Series 14, 1948, 39 pp.

El Paso, Tex.

Sayre, A. N., and P. P. Livingston, Ground-rvater Resources of the El Paso Area, Texas, U.S. Geol. Survey Water Supply Paper 919, 1945, 190 pp.

Scalapino, R. A., Ground-water Resources of the El Paso Area, Texas, Texas Board Water Engrs. Progress Rept. 6, 1949, 22 pp.

Elephant Butte, N.Mex.

Conover, C. S., "Ground-water Conditions in the Rincon and Mesilla Valleys and Adjacent Areas in New Mexico," U.S. Geol. Survey, Typed rept., October 1950, 316 pp.

Ellendale, N.D.

Wenzel, L. K., and H. H. Sand, Water Supply of the 
Dakota Sandstone, U.S. Geol. Survey Water Supply Paper 889, pp. 1-81, 1942.

Enid, Okla.

Schoff, S. L., "Ground-water Conditions in the Vicinity of Enid, Oklahoma," U.S. Geol. Survey, Mimeo. rept., 1949.

Escalante Valley, Utah

Fix, P. F., et al., Ground Water in Escalante Valley, Utah, Utah State Engr. 27th Bienn. Rept., pp. 109-210, 1951 .

Everglades, Fla.

Jones, L. R., et al., Soils, Geology, and Water Control in the Everglades Region, Univ. Florida Agr. Exp. Sta. Bull. 442, p. 168, 1948.

Parker, G. G., et al., Water Resources of Southeast Florida, U.S. Geol. Survey Water Supply Paper, in preparation.

Fargo, N.D.

Dennis, P. E., P. D. Akin, and G. F. Worts, "Geology and Ground-water Resources of Parts of Cass and Clay Counties, North Dakota and Minnesota," U.S. Geol. Survey, Mimeo. rept., 1949, 177 pp.

Fernandina, Fla. (See Jacksonville, Fla.)

Fessenden, N.D.

Filaseta, Leonard, "Ground Water in the Fessenden Area, Wells County, North Dakota," N.D. Geol. Survey, Mimeo. rept., 1946, 22 pp.

Ft. Myers, Fla.

Parker, G. G., Municipal Water-supply Problems of Southern Florida, Soil Sci. Soc. Florida, vol. 8, pp. $72-$ 88, 1946.

Fort Worth, Tex. (See Dallas, Tex.)

Galveston, Tex. (See Houston, Tex.) 
Gila Bend, Ariz.

Babcock, H. M., and K. K. Kendall, "Geology and Ground-water Resources of the Gila Bend Basin, Maricopa County, Arizona," U.S. Geol. Survey, Mimeo. rept., 1948, 26 pp.

Goleta Valley, Calif. (See Santa Barbara Valley, Calif.)

Grand Prairie, Ark.

Engler, Kyle, D. G. Thompson, and R. G. Kazmann,

Ground-water Supplies for Rice Irrigation in the Grand Prairie Region, Arkansas, Univ. Ark. Agr. Exp. Sta. Bull. 457, 1945, 55 pp.

Green Bay, Wis. (See Madison, Wis.)

Gulfport, Miss.

Brown, G. F., et al., Geology and Ground-water Resources of the Coastal Area of Mississippi, Miss. Geol. Survey Bull. 60, 1944.

Helena Valley, Mont.

Lorenz, H. W., F. A. Sivenson, and H. A. Swenson, Geology and Ground-water Resources of the Helena Valley, Montana, U.S. Geol. Survey Circ. 83, in press.

High Plains, Kans.

Waite, H. A., Factors Producing a Nine-year Decline in Ground-water Levels in Scott County, Kansas, Trans. Am. Geophys. Union, vol. 22, pp. 772-775, 1941.

Frye, J. C., and V. C. Fishel, "Ground Water in Southwestern Kansas," Kans. Geol. Survey, 1949, 24 pp.

High Plains, N.Mex.

Theis, C. V., Progress Reports on the Ground-water Supply of the Portales Valley, and of Lea County, New Mexico, N.Mex. State Engr., 12th-13th Bienn. Rept., pp. 101-119, 121-134, 1938.

High Plains, Okla.

Schoff, S. L., Ground Water in the Oklahoma Panhandle, Econ. Geol., vol. 35, pp. 534-545, 1940. 
High Plains, Tex.

Barnes, J. R., et al., Geology and Ground Water in the Irrigated Region of the Southern High Plains of Texas, Texas Board Water Engrs. Progress Rept. 7, $1949,51 \mathrm{pp}$.

Houston, Tex.

Guyton, W. F., Application of Coefficients of Transmissibility and Storage to Regional Problems in the Houston District, Texas, Trans. Am. Geophys. Union, vol. 22, p. 767, 1941.

Texas Board of Water Engineers, Progress Rept. for period September 1, 1946-August 31, 1948, pp. 27-131, 1948.

Lang, J. W., and A. G. Winslow, "Geology and Groundwater Resources of the Houston District, Texas," Texas Board Water Engrs. Bull. 5001, October 1950, $36 \mathrm{pp}$.

Imperial Valley, Calif.

Aronovici, V. S., W. W. Fox, and W. W. Donnan, "Imperial Valley Drainage Investigation," U.S. Soil Cons. Service, Progress rept., 1944.

Indianapolis, Ind.

McGuinness, C. L., "Ground-water Resources of the Indianapolis Area, Marion County, Indiana," Ind. Dept. Cons., Div. Geol., Mimeo. rept., Jan. 1943, $49 \mathrm{pp}$.

Intracoastal Waterway, N.J.

Barksdale, H. C., and C. E. Jacob, "The Effect of the Proposed New York Bay-Delaware River Section of the Intracoastal Waterway on the Ground Waters of New Jersey," U.S. Geol. Survey, Typed rept., 1945, $66 \mathrm{pp}$.

Iron River District, Mich.

Stuart, W. T., C. V. Theis, and G. M. Stanley, Ground- 
water Problems of the Iron River District, Michigan, Mich. Dept. Conserv., Geol. Survey Div. Tech. Rept. 2, 1948, 58 pp.

Ivanpah Valley, Nev.

Thompson, D. G., The Mojave Desert Region, U.S. Geol. Survey Water Supply Paper 598, p. 608, 1929.

Jacksonville, Fla.

Cooper, H. H., Jr., Ground-water Investigations in Florida, with Special Reference to Duval and Nassau Counties, Jour. Am. Water Works Assoc., vol. 36, pp. $169-185,1944$.

Cooper, H. H., Jr., and M. A. Warren, The Perennial Yield of Artesian Water in the Coastal Area of Georgia and Northeastern Florida, Econ. Geol., vol. 40, pp. 263-282, 1945.

Lake Charles and the Rice Area, La.

Fisk, H. N., "A Geological Investigation of the Mississippi Alluvial Valley," Mississippi River Commission, Vicksburg, Miss., 1944, 78 pp. plus 33 pp.

Jones, P. H., and A. N. Turcan, Ground-water Use for Rice Irrigation in Southwestern Louisiana, Rice News, vol. 16, no. 1, 1949.

Jones, P. H., Ground Water, An Advance Look at a Forthcoming Report by U.S. Geologists, Rice News, Vol. 14, no. 10, 1947; Ground-water Summary, Rice News, vol. 15, no. 12, pp. 3-7, 1948.

Las Vegas Valley, Nev.

Maxey, G. B., and C. H. Jameson, Geology and Water Resources of Las Vegas, Pahrump, and Indian Spring Valleys; Nevada, Nev. State Engr. Water Res. Bull. 5, 1948, $121 \mathrm{pp}$.

Lea County, N.Mex. (See High Plains, N.Mex.)

Long Island, N.Y. (See Brooklyn, N.Y.) 
Los Angeles Coastal Plain, Calif.

Overdraft on Ground-water Basins, South Coastal Basin Investigations, Calif. Div. Water Res. Bull. 53, 1947, $256 \mathrm{pp}$.

Poland, J. F., A. A. Garrett, and Allen Sinnott, "Geology, Hydrology, and Chemical Character of the Ground Waters in the Torrance-Santa Monica Area, Los Angeles County, Calif.," U.S. Geol. Survey, Duplicated rept., 1948, 472 pp.

Bailey, Paul, "Pollution of the Water Supply of Orange County by Industrial Wastes," Report of Interim Factfinding Committee on Water Pollution to the Assembly of the State of California, p. 142, 1949.

Louisville, Ky.

Guyton, W. F., Depleted Wells at Louisville Recharged with City Waters, Water Works Eng., vol. 98, pp. 1820,1945 .

Rorabaugh, M. I., "Ground-water Resources of the Northeast Part of the Louisville Area, Kentucky," Louisville Water Co., Mimeo. rept., July, 1948, 77 pp. Madison, Wis.

Foley, F. C., Ground Water, in "The Sciences and Conservation," Univ. of Wis. Centennial Conference on Conservation, 1949.

Memphis, Tenn.

Schneider, Robert, and E. M. Cushing, Geology and Water-bearing Properties of the "1400-foot" Sand in the Memphis Area, U.S. Geol. Survey Circ. 33, 1948, $13 \mathrm{pp}$.

Kazmann, R. G., "The Water Supply of the Memphis Area," U.S. Geol. Survey, Duplicated rept., September 1944, 66 pp.

Mesilla Valley, N.Mex. (See Elephant Butte, N.Mex.)

Miami, Fla. (See Everglades, Fla.) 
Miami, Okla.

"Oklahoma Water," Okla. Planning and Resources Board, Photolith rept., p. 104, 1945.

Schoff, S. L., "Ground-water Supplies and Uses in Oklahoma," 3rd Annual Wild Life Conference, June 1948.

Middlesex County, N.J. (See Perth Amboy, N.J.)

Mill Creek Valley, Ohio

Bernhagen, R. J., and E. J. Schaefer, Ground-water Conditions in Butler and Hamilton Counties, Ohio, 1946, Ohio Water Res. Board Bull. 8, 1947, 35 pp.

Milwaukee, Wis.

Drescher, W. J., "Results of Pumping Tests on Artesian Wells in the Milwaukee-Waukesha Area, Wisconsin," Univ. Wis. and U.S. Geol. Survey rept., 1948.

Mimbres Valley, N.Mex.

Theis, C. V., Progress Report on the Ground-water Supply of Mimbres Valley, New Mexico, N.Mex. State Engr., 12th-13th Bienn. Rept., pp. 135-154, 1938.

Minneapolis, Minn.

Bradley, Edward, "Artesian Water Supply of the Twin Cities Basin," Minn. Geol. Surv., Mimeo. rept., 1949, $18 \mathrm{pp}$.

Mobile, Ala.

Peterson, C. G. B., Ground-water Investigation in the Mobile Area, Alabama, Ala. Geol. Survey Bull. 58, 1947, 32 pp.

Montgomery, Ala.

Carlston, C. W., Ground-water Resources of the Cretaceous of Alabama, Ala. Geol. Survey Special Rept. 18, 1944.

Natchitoches, La.

Maher, J. C., and P. H. Jones, Ground Water and Geo- 
logic Structure of Natchitoches Area, Louisiana, $A m$. Assoc. Petroleum Geol. Bull., vol. 29, pp. 23-24, 1945.

Newark, N.J.

Erickson, E. T., Using Runoff for Ground-water Recharge, Jour. Am. Water Works Assoc., vol. 41, pp. 647-649, 1948.

Herpers, Henry, and H. C. Barksdale, "Preliminary Report on the Geology and Ground-water Supply of the Newark Area, New Jersey," N.J. Div. of Water Policy and Supply, Special rept., in preparation.

Norman, Okla.

"Oklahoma Water," Okla. Planning and Resources Board, Photolith rept., pp. 111-113, 1945.

Ogden Valley, Utah

Thomas, H. E., The Ogden Valley Artesian Reservoir, Utah State Engr. Tech. Pub. 2, 1945, 37 pp.

Oklahoma City, Okla.

Jacobsen, C. L., and E. WV. Reed, Ground-water Supplies in the Oklahoma City Area, Oklahoma, Okla. Geol. Survey Mineral Rept. 20, 1949.

Orlando, Fla.

Unklesbay, A. G., Ground-water Conditions in Orlando and Vicinity, Florida, Fla. State Board of Cons., Rept. of Inv. 5, 1944, 72 pp.

Parkersburg, W.Va.

Jeffords, R. M., Ground-water Conditions along the Ohio Valley at Parkersburg, West Virginia, W.Va. Geol. Survey Bull. 10, 1945, 57 pp.

Jeffords, R. M., Recharge to Water-bearing Formations along Ohio River Valley, Jour. Am. Water Works Assoc., vol. 37, pp. 144-154, 1945.

Coffield, C. C., Horizontal Type Well Increases Groundwater Yield, Water Works Eng., vol. 100, no. 7, pp. 346-349, 1947. 
Parlin, N.J.

Barksdale, H. C., The Contamination of Ground Water by Salt Water near Parlin, New Jersey, Trans. Am. Geophys. Union, vol. 21, pp. 471-474, 1940.

Barksdale, H. C., Depletion of Ground Water in New Jersey, Jour. Am. Water Works Assoc., vol. 41, pp. $511-515,1949$.

Pasadena, Calif.

Pasadena v. Alhambra, 33 Cal. 2d 908, 207 P. 2d 17 (1949); certiorari denied, 339 U.S. 937 (1950).

Pavant Valley, Utah

Dennis, P. E., G. B. Maxey, and H. E. Thomas, Ground Water in Pavant Valley, Utah, Utah State Engr. Tech. Pub. 3, 1946, 96 pp.

Pensacola, Fla.

Jacob, C. E., et al., "Ground-water Resources of the Pensacola Area, Florida," U.S. Geol. Survey, Duplicated rept., 1940, 2 pp.

Peoria, Ill.

Suter, Max, Apparent Changes in Water Storage During Floods at Peoria, Illinois, Trans. Am. Geophys. Union, vol. 28, pp. 425-437, 1947.

Control of Ground Water, Illinois Legislative Council Publ. 88, pp. 7-8, 1948.

Larson, T. E., Geologic Correlation and Hydrologic Interpretation of Water Analyses, Ill. State Water Survey Circ. 27, 1949, 8 pp.

Horberg, Leland, "Ground Water and Geology of the Peoria Region, Illinois," Ill. State Geol. Survey, Unpublished rept., 1946.

Ground Water in the Peoria Region, Ill. State Water Survey Bull. 39, in press.

Perth Amboy, N.J.

Barksdale, H. C., et al., The Ground-water Supplies of 
Middlesex County, New Jersey, N.J. Water Policy Comm., Special Rept. 8, 1943, 160 pp.

Philadelphia, $P a$.

Graham, J. B., Ground-water Problems in the Philadelphia Area, Econ. Geol., vol. 45, pp. 210-221, 1950.

Graham, J. B., et al., Water Resources of Southeastern Bucks County, Pennsylvania, U.S. Geol. Survey Circ. 104, in press.

Pittsburgh, $P a$.

Adamson, J. H., J. B. Graham, and N. H. Klein, Ground-water Resources of the Valley-fill Deposits of Allegheny County, Pennsylvania, Pa. Topographic and Geol. Survey Bull. W-8, 1949.

Adamson, J. H., Ground Water in the Pittsburgh Area, Monthly Bull. Pa. Dept. of Internal Affairs, vol. 17, no. 10, pp. 26-32, 1949.

Van Tuyl, D. W., Ground-water Resources of the Valleyfill Deposits in the Pittsburgh Area, Penn. Jour. Science, in press.

Platte River Valley, Nebr.

Waite, H. A., et al., Progress Report on the Geology and Ground-water Hydrology of the Lower Platte River Valley, Nebraska, U.S. Geol. Survey Circ. 20, 1949, $211 \mathrm{pp}$.

Portales Valley, N.Mex. (See High Plains, N.Mex.)

Rahway Valley, N.J.

Barksdale, H. C., Depletion of Ground Water in New Jersey, Jour. Am. Water Works Assoc., vol. 41, pp. $511-515,1949$.

Rincon Valley, N.Mex. (See Elephant Butte, N.Mex.)

Rio Grande Valley, N.Mex.

"Regional Planning, Part VI, The Rio Grande Joint Investigation in the Upper Rio Grande Basin," National Resources Committee, vol. 1, 1938, 566 pp. 
Rockford, Ill.

Smith, H. F., and T. E. Larsen, Ground-water Resources in Winnebago County, Illinois, Ill. State Water Survey, Rept. Invest. 2, 1948, 33 pp.

Roswell Basin, N.Mex.

Fiedler, A. G., and S. S. Nye, Geology and Ground-water Resources of the Roswell Artesian Basin, N.Mex., U.S. Geol. Survey Water Supply Paper 639, 1933, 372 pp.

Morgan, A. M., "Geology and Shallow-water Resources of the Roswell Artesian Basin, New Mexico," N.Mex. State Engr., 12th-13th Bienn. Rept., pp. 155-249, 1938.

Bliss, J. H., Ground-water Problems of New Mexico, Assoc. Western State Engr. Proc. 21, pp. 55-58, 1948.

Safford Valley, Ariz.

Turner, S. F., et al., "Ground-water Resources and Problems of the Safford Basin, Arizona," U.S. Geol. Survey, Mimeo. rept., December 1946, 28 pp.

Gatewood, J. S., et al., Use of Water by Bottom-land Vegetation in Lower Safford Valley, Arizona, U.S. Geol. Survey Water Supply Paper 1103, 1950, 210 pp.

St. Paul, Minn. (See Minneapolis, Minn.)

St. Petersburg, Fla.

Cooper, H. H., Jr., N. D. Hoy, and A. O. Patterson, "The Water Situation in Florida," U.S. Geol. Survey, Unpublished rept., 1950, $13 \mathrm{pp}$.

Heath, R. C., and R. C. Smith, "Ground-water Conditions in Pinellas County, Florida," U.S. Geol. Survey rept., in preparation.

Salinas Valley, Calif.

Simpson, T. R., Salinas Basin Investigations, Calif. Div. Water Res. Bull. 52, 1946, 230 pp.

Salt Flat Basin, Tex.

Scalapino, R. A., Development of Ground Water for 
Irrigation in the Dell City Area, Hudspeth County, Texas, Texas Board Water Engrs. Bull. 5004, September 1950,38 pp.

Salt River Valley, Ariz.

Bluhm, F. I., and H. N. Wolcott, "Ground-water Resources of Deer Valley, Maricopa County, Arizona," U.S. Geol. Survey, Mimeo. rept., October 1949, 23 pp.

San Antonio, Tex.

Livingston, Penn, et al., Water Resources of the Edwards Limestone in the San Antonio Area, Texas, U.S. Geol. Survey Water Supply Paper 773, pp. 59-113, 1936.

San Fernando Valley, Calif.

Geology and Ground-water Storage Capacity of Valley Fill, South Coastal Basin Investigations, Calif. Div. Water Res. Bull. 45, 1934, 273 pp.

Blaney, H. F., and W. W. Donnan, "Ground-water Situation in San Fernando Valley, California," U.S. Soil Cons. Service, Mimeo. rept., December 1945, 56 pp.

San Joaquin Valley, Calif.

Forbes, Hyde, Geology of the San Joaquin Valley as Related to the Sources and Occurrence of Ground-water Supply, Trans. Am. Geophys. Union, vol. 22, part I, pp. 8-20, 1941.

Comprehensive Plan for Water Resources Development, Central Valley Basin, California, U.S. Bur. Recl. Project Planning Rept. 2-4, o-3, p. 229, November 1945.

Ewing, F. A., "Irrigation and Drainage in San Joaquin Valley, California," U.S. Soil Cons. Service, Mimeo. rept., 1946, 80 pp.

Trauger, F. D., "Description of an Early Experiment in Ground-water Recharge through Wells at Lindsay, California," Unpublished rept., 1949, 10 pp.

Ingerson, I. M., "Ground-water Conditions in Califor- 
nia," presented at Conference of Agricultural Extension Service, Univ. Calif., February 1949.

Muckel, D. C., "Report to Cooperators on Water-spreading Investigations in San Joaquin Valley, California," U.S. Soil Cons. Service, pp. 4-16, April 1949.

Stoner, D. S., "Ground-water Investigations in the Central Valley," U.S. Bur. Recl. Region 2, Mimeo. rept., July 1950, 172 pp.

San Luis Valley, Colo.

Robinson, T. W., and H. A. Waite, "Ground Water in the San Luis Valley, Colorado," U.S. Geol. Survey (contribution to the Rio Grande Joint Investigation), Mimeo. rept., 1937, 119 pp.

"Water Facts in Relation to a National Water-resources Policy," U.S. Geol. Survey, Mimeo. rept., Appendix C, pp. 24-26, April 1950.

Santa Barbara Valley, Calif.

Upson, J. E., et al., Geology and Ground-water Resources of the South Coastal Basins, Santa Barbara County, California, U.S. Geol. Survey Water Supply Paper 1108, in press.

Santa Clara Valley, Calif.

Hunt, G. W., Description and Results of Operation of the Santa Clara Water Conservation District's Projects, Trans. Am. Geophys. Union, vol. 21, part I, pp. 13-22, 1940.

Tolman, G. F., and J. F. Poland, Ground Water, Saltwater Infiltration and Ground-surface Recession in Santa Clara Valley, California, Trans. Am. Geophys. Union, vol. 21, pp. 7, 23-34, 1940.

Hunt, G. W., "Proposed Lexington Dam and Conservation Works," Report to Board of Directors of Santa Clara Valley Conservation District, 1947, 20 pp.

Santa Cruz Valley, Ariz.

Turner, S. F., et al., "Ground-water Resources of the 
Santa Cruz Basin, Arizona," U.S. Geol. Survey, Mimeo. repts., May 1943, 84 pp.; March 1947, 45 pp.

Savannah, Ga.

Warren, M. A., Artesian Water in Southeastern Georgia, Ga. Geol. Survey Bull. 49, 1944, 140 pp.

Sierra Ancha Experimental Forest, Ariz.

Rich, L. R., "Consumptive Use of Water by Forest and Range Vegetation," Am. Soc. Civil Engrs., April 1950 meeting, $19 \mathrm{pp}$.

Snake River Plain, Idaho

Stearns, H. T., Lynn Crandall, and W. G. Steward, Geology and Ground-water Resources of the Snake River Plain in Southeastern Idaho, U.S. Geol. Survey Water Supply Paper 774, 1938, 268 pp.

Stearns, H. T., L. L. Bryan, and Lynn Crandall, Geology and Water Resources of the Mud Lake Region, Idaho, U.S. Geol. Survey Water Supply Paper 818, 1939, 122 pp.

Nace, R. L., "Preliminary Report on Ground Water in Minidoka County, Idaho, with Special Reference to the North Side Pumping Division of the Minidoka Project," October 1948, 71 pp.; in U.S. Bur. Recl. Proj. Planning Rept. 1-5.53-1, Mimeo., April 1949.

South Bend, Ind.

Klaer, F. H., Jr., and R. W. Stallman, Ground-water Resources of St. Joseph County, Indiana, Ind. Div. of Water Res. Bull. 3, 1948, 82 pp.

Spokane, Wash.

Piper, A. M., and G. A. LaRocque, Jr., Water-table Fluctuations in the Spokane Valley and Contiguous Area, Washington-Idaho, U.S. Geol. Survey Water Supply Paper 889, pp. 83-189, 1944.

Susquehanna River Basin, Pa. and N.Y.

Merriam, C. F., Interpretation of Natural Fluctuations 
of Ground Water in Terms of River Flow, Jour. Am. Water Works Assoc., vol. 37, pp. 632-637, 1945; Ground-water Records in River-flow Forecasting, Trans. Am. Geophys. Union, vol. 29, pp. 384-386, 1948.

Tampa, Fla. (See St. Petersburg, Fla.)

Tooele Valley, Utah

Thomas, H. E., Ground Water in Tooele Valley, Utah, Utah State Engr., 25th Biennial Rept., pp. 97-238, 1946.

Utah Valley, Utah

Hunt, C. B., H. E. Thomas, and Helen Varnes, "The Bonneville Basin, Part I, Northern Utah Valley," U.S. Geol. Survey rept., in preparation.

Virden Valley, N.Mex. (See Duncan Valley, Ariz.)

Wasatch Experimental Forest, Utah

Croft, A. R., Water Loss by Stream Surface Evaporation and Transpiration by Riparian Vegetation, Trans. Am. Geophys. Union, vol. 29, pp. 235-239, 1945.

Thomas, H. E., and W. B. Nelson, Ground Water in the East Shore Area, Utah, Utah State Engr., 26th Bienn. Rept., pp. 109-119, 1948.

Croft, A. R., A Water Cost of Runoff Control, Jour. Soil and Water Cons., vol. 5, pp. 13-15, 1950.

Wellton-Mohawk Area, Ariz.

Babcock, H. M., S. C. Brown, and J. D. Hem, "Geology and Ground-water Resources of the Wellton-Mohawk Area, Yuma County, Arizona," U.S. Geol. Survey, Mimeo. rept., 1947, 22 pp.

Wichita, Kans.

Williams, C. C., and S. W. Lohman, Geology and Ground-water Resources of a Part of South Central Kansas, Kans. Geol. Survey Bull. 79, 1949, 451 pp. 
Willamette Valley, Ore.

Piper, A. M., Ground-water Resources of the Willamette Valley, Oregon, U.S. Geol. Survey Water Supply Paper $890,1942,194 \mathrm{pp}$.

Willcox Basin, Ariz.

Jones, R. S., and R. L. Cushman, "Geology and Groundwater Resources of the Willcox Basin, Cochise and Graham Counties, Arizona," U.S. Geol. Survey, Mimeo. rept., May 1947, 35 pp.

Wilmington, N.C.

Mundorff, M. J., Ground Water in North Carolina, N.C. Div. of Mineral Res. Bull. 47, p. 48, 1945.

Winter Garden, Tex.

Texas Board of Water Engineers, Progress Rept. for the period September 1, 1946-August 31, 1948, pp. 119$125,1948$.

Sundstrom, R. W., and C. R. Follett, Ground-water Resources of Atascosa County, Texas, U.S. Geol. Survey Water Supply Paper 1079, pp. 107-153, 1950. 



\section{SUBJECT INDEX}

A

Abandoned valleys, 112, 226

Agricultural use of water, 213, 216, 221

Air conditioning, 220-222

American doctrine of water rights, 245

Apportionment, under correlative doctrine, 256

of interstate waters, 259

Appropriation doctrine, 61, 246

Aquifers, definition of, $4 n$.

Areas of perennial water deficiency, 25

Arid and semiarid regions, 25

Artesian aquifers, 33

Artesian conditions, 33

Artesian pressure, 33

equilibrium after pumping, 101

outstanding reductions, 101-123

recovery after cessation of pumping, 109

Artesian water, rising through confining beds, $63,65,198,206$

Artificial recharge, 67, 142 coordinated with flood control, 188, $226,241,274$

effect of vegetal cover, 189 indiscriminate efforts, 190, 274

with reclaimed water, 57

\section{B}

Basalt aquifers, 89

Beneficial use of water, 61

Brines, natural, 148 oil field waste, 149

Buried valleys, 112, 146

Burning of vegetation, 168
C

California doctrine of water rights, 245

Clay, compaction of, 53, 206 impeding recharge, 49, 106 movement of water through, 199

Clearing of vegetation, 167

Common-law doctrine, 243

Concentrated draft from wells, 109 water levels declining, 71, 110-115 water levels at equilibrium, 116118

Cone of depression, 98

disappearance of, 109

Confined water, 33

Conflicting demands for storage, 269

Connate water, 44,270

Conservation of renewable resources, 279

conflicts in, 278

(See also Water conservation)

Consumptive use, 215

by vegetation, 216

Consumptive waste, 217

Contamination, by agricultural use, $58,148,199$

by industry, $65,131,149$

by mine waters, 204

by natural processes, 76,190

reduced by pumping, 131

by sewage, 201-203

by wells, 44,131

(See also Salt-water encroachment)

Correlative rights, 245

Cost of obtaining water, increasing with development, 255

legal aspects of, 256

(See also Water cost)

Cultivation, 167 


\section{D}

Declining water levels, significance of, 271-272

Deficiencies, in hydrologic knowledge, 228,281

in legal concepts, 243

Definite underground streams, 248

Detention storage, 179

Deterioration in quality (see Contamination)

Diffused surface waters, 248

Disposal of water, inventory of, 239 methods of, 217

Drainage, by ditches, 194, 197 by pumping, 196, 197

of mines, 82, 196

Drainage wells, 202

Dug wells in poorly permeable mate. rials, 32

\section{E}

Erosion, climatic factors in, 183

geologic factors in, 183

related to vegetal cover, 180

Evaporation, from reservoirs, 76, 241 from soil, 199

Evapotranspiration, definition of, 15 potential, 21

proportion of precipitation, 216 relation to temperature, 172,186 rights to water salvaged, 252

\section{F}

Facilities for water storage, 26-27

Fallow land, 163

Fault barriers, 52, 56, 114

Flood control, coordinated with artificial recharge, $60,77,274$

Flood-detention reservoirs, 226

Floods, increased by drainage, 194 reduced, by forest cover, 179 by ground-water recharge, 157 , 226

Fluctuations of water levels in wells, index of stream flow, 237
Fluctuations of water levels in wells, significance of, 271-272

(See also Artesian pressure; Water table)

Forest cover, 177-181

\section{G}

Glacial drift aquifers, 48

Glacial recession, 173

Grass cover, 167, 184

Gravity, 15

Ground water, inventory of, 235-237

Ground-water reservoirs, changes of storage in, 32

definition of, 28

delineation of, 29

fully developed, 92

overdeveloped, 37-51

partly developed, 77-91

volume in storage, 28,236

maintenance of constant, 273

Ground-water supplies, advantages of, 223, 225

disadvantages of, 224

H

Heat-exchange systems, 222

Holdover storage, 96, 274

Humid regions, 25, 91, 99

Hydroelectric power, use of water in, 214

Hydrologic cycle, definition of, 15

legal priorities of, 249

natural priorities of, 17

phases of, 19, 234

unity of, 231

Hydrologic data, analysis of, 233

collection of, 232, 233

coordination of, 23t-236

national policy for, 235

I

Importation of water, 68

Industrial use of water, 213 
Infiltration, rates of, 164,190 affected, by burning brush, 168 by cities, 191

by clearing, 167

by cultivation, 166

by forest cover, 167

by grass cover, 167

by industrial wastes, 204

vs. runoff, 164

Infiltration gallery, 142

Interception, 182

Interstate compacts, 156, 160, 259

significance of water quality in, 260

Interstate water, apportionment of, 259

rights of source areas, 258

L

Land management related to waterresource planning, 277

Land subsidence, caused by drainage, 195

caused by pumping, 53

Legal classification of waters, 247-249

Legal doctrines, 243-246

Legal protection in means of diversion, 255-258, 264

Legislation, effect on development, $264-267,288$

Limestone aquifers, 62, 116, 132 danger of pollution of, 202

Limits of development, 228

"Lost" water, 252

\section{M}

Management of water resources, principal lines of action, 282

Manipulation of storage, 193, 226 for flood control, 157, 226

for greater utilization, 55, 240

prerequisite for full development, 273-275

Mineralization of water (see Quality of water)

Mining of water, 41, 94, 263

basis for permanent economy, 279
Movement of ground water, 28, 98, 224

Mud-rock flows, 182

Multiple-purpose reservoirs, 269

Multiple use of water, 154, 272

Municipal use of water, 213

\section{$\mathrm{N}$}

Natural ground-water discharge, estimate for western United States, 83

evidence of undeveloped potential, 78

problems of salvaging, 92-97

reduced by lowering water table, 157

reduced by surface storage, 205

Navigation, use of water for, 215

Nonconsumptive use, effect of, 218

O

Oil-field brines, 149

Organic soil aquifers, 179, 195

Overland flow, affected, by man's activity, 162-169

by vegetal cover, $177-181$

\section{P}

Percolating waters, 249

Perennial overdraft, $37-51$

Plugging of "wild" wells, 61, 65

Pollution, in limestone aquifers, 202 reduced by river infiltration, 150 , 201-202

by sewage, 201

Precipitation, inventory of, 20 legal right to, 247, 250

Preferential use of water, 253

Program for water-resource management, 282

Properties of water, 218

Purification of water, 200, 218, 273 
Q

Quality of water, legal rights to, 255 from soluble rocks, 76,148

(See also Contamination; 'Treatment)

$\mathrm{R}$

"Rain making," 251

Reasonable use of water, 245

Recession of glaciers, 173

Recharge, artificial (see Artificial recharge)

by irrigation water, 193

by precipitation, $189,192,242$

by streams, $188,206,208$

limited, by climate, $40-43$

by geology, $42-17$

rejected, 127,206

Recharge areas, definition of, 29 proportion of total land area, 190

Recharge basins, 143, 188

Recharge ponds, 53, 128

Recharge wells, 75, 100, 125, 147

Recirculation of water, 80, 141, 273

Recreational use of water, 215

Redistribution of wells, 100,120

Reduction, in pumping, 60 in waste of water, 61

Regulation of development and use, 61

Reuse of water, 215

legal rights in, 255

Rice irrigation, requirements, 49, 106

River-basin development, 229

River infiltration, 138

reduced, by industrial waste, 201

by silt, 144,207

Runoff (see Overland flow; Stream flow)

\section{S}

Safe yield, 261

Saline water, suitability of, 126, 130, 150,238

Salt, left by evaporation, 59, 199

removed from soil, 221
Salt-water encroachment, from contaminated streams, 149

from navigation channels, 208, 210 , 212

from oceans, 51,123

from other aquifers, 57, 109, 134

from tidal streams, 148

through drainage structures, 195

through wells, 44, 53, 131

Salvage of unused water, by creating storage space, 55

by diverting to areas of shortage, 70-76

by reducing natural discharge, 80 $82,94,95$

water rights acquired by, 252

Sand aquifers, 47, 128, 135

Sandstone aquifers, 101, 119 poorly permeable, 115

"Saved" water, 221, 252

Sea level, rise in historic time, 174

Sediment, in reservoirs, 181

in streams, 187,208

Sewage, natural purification of, 201

Sewage effluent, 54, 67, 126

Soil moisture, 28

increased by conservation practices, 163-168

legal right to, 251

Solar energy, 15

Spreading areas, 67, 189

Spring discharge increased by irrigation, 90

Sprinkler irrigation, 221

Steel mills, water use by, 80

Storage space, as an asset, 226

created by pumping, $50,71,113$

inadequate for current use, 140

Stream flow, inventory of, 21

relation to ground water, $138,150-$ 160,266

Subirrigation, 88, 194

Subsurface storm flow, 177

Supplemental irrigation in humid areas, 220

Synthetic oil manufacture, requirement for water, 222 
$\mathrm{T}$

Temperature, of air, increase in historic time, 172

of water, increased by use, 219

Temporary overdraft, 279

Transmissivity of aquifers, 98

Treatment, of industrial water, 219 of sea water, 273

of sewage, 218

\section{U}

Underflow, 137

leaving drainage basin, 155

Underground storage, alternative to surface storage, 241

Units of water measurement, $37 n$

Utilization of water, 213

inventory of, 237

\section{V}

Vegetal cover, draft on water resources, $85,163,181$

in recharge basins, 189

Volcanic rock aquifers, 41, 89

W

Waste, reduction of, 61

Waste water, legal right to, 255

use of, 214

Water-bearing formation, 4

Water conservation, by economy in use, 268

by nonuse, 278

by storage in reservoirs, 269

for maintenance of quality, 268
Water cost, 181

of barren land, 185, 187

of "deteriorated" vegetation, 185

of forest cover, 179

of grass cover, 181

of riparian vegetation, 180

of surface reservoirs, 241

of water-loving vegetation, 83,84 , 153

Water rights, 243

based on priority of use, ground water vs. surface water, 261

importance of reasonable cost, 256

Water table, 32

lowered, by drainage, 194

by dry cycles, 77,171

by erosion, 170

by navigation channel, 212

by pumping, 33,257

by storm sewers, 191

raised, by flood-protection devices, 208

by irrigation, 90, 152, 193, 199

by sedimentation, 152

regulation of, 197, 272

Watercourses, 136

potentialities of, 144, 226

surface waters in, 247

Waterlogging, by artesian pressure, 199

by irrigation, $86-90,152$

by levee construction, 208

by sedimentation, 152

reduced, by drainage, 197

by pumping, 197

Well drilling, advance in techniques, 230

Y

Yield of wells and springs, increased by surface reservoirs, 205 





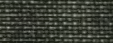

$$
+4+4+4
$$

(5)

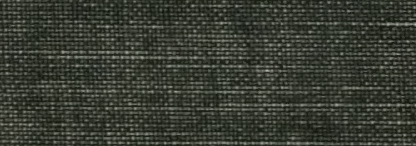

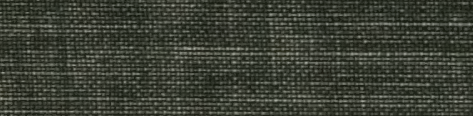

$+\quad+5+5,+4$ 